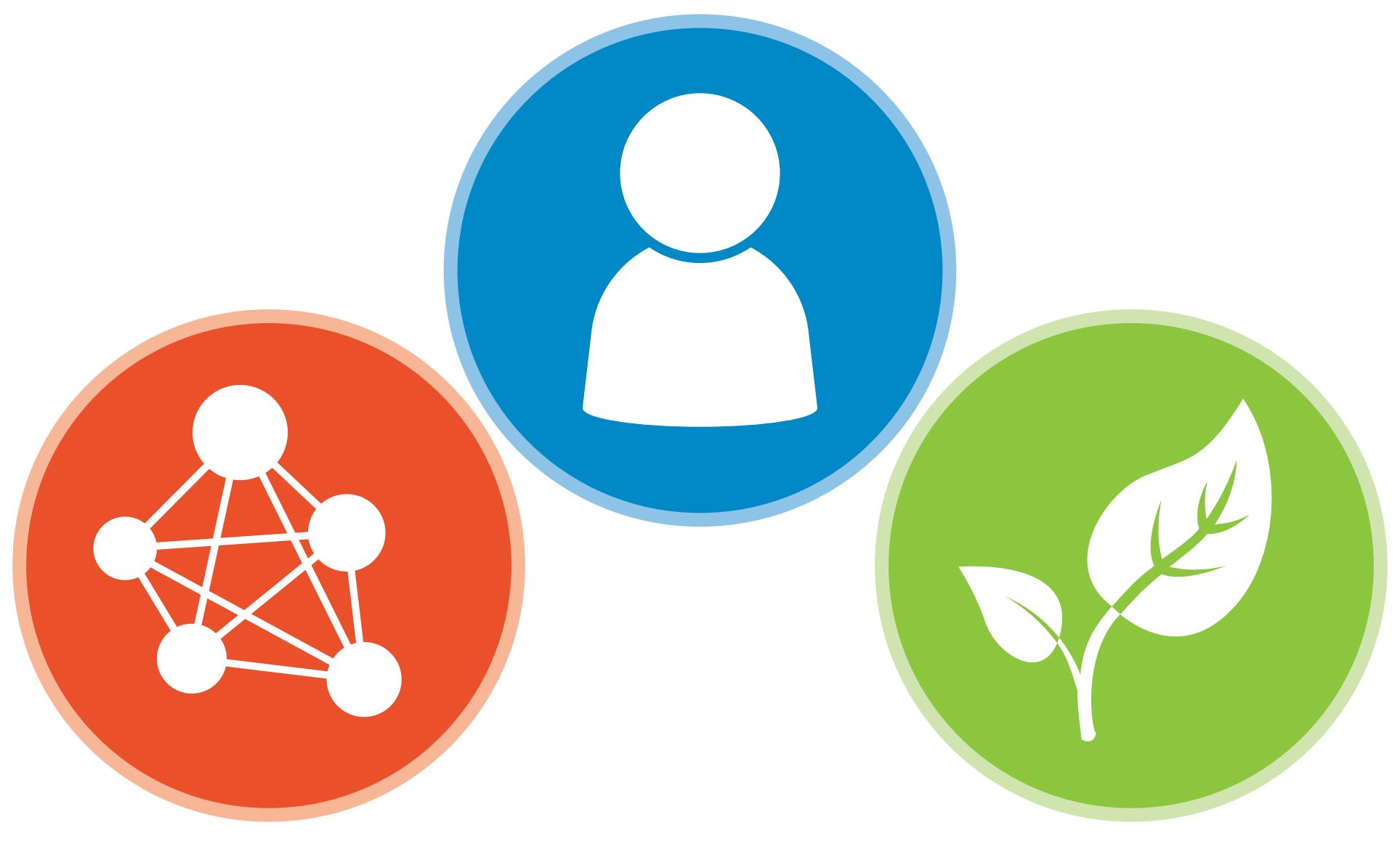

\title{
HEALTH IMPACT ASSESSMENT
}

A GOOD PRACTICE SOURCEBOOK

OCTOBER 2018 



\section{HEALTH IMPACT ASSESSMENT}

A GOOD PRACTICE SOURCEBOOK

OCTOBER 2018 
(C) 2018 Asian Development Bank

6 ADB Avenue, Mandaluyong City, 1550 Metro Manila, Philippines

Tel +632632 4444; Fax +6326362444

www.adb.org

Some rights reserved. Published in 2018.

ISBN 978-92-9261-308-2 (print), 978-92-9261-309-9 (electronic)

Publication Stock No. TIM189515-2

DOI: http://dx.doi.org/10.22617/TIM189515-2

The views expressed in this publication are those of the authors and do not necessarily reflect the views and policies of the Asian Development Bank (ADB) or its Board of Governors or the governments they represent.

ADB does not guarantee the accuracy of the data included in this publication and accepts no responsibility for any consequence of their use. The mention of specific companies or products of manufacturers does not imply that they are endorsed or recommended by ADB in preference to others of a similar nature that are not mentioned.

By making any designation of or reference to a particular territory or geographic area, or by using the term "country" in this document, $\mathrm{ADB}$ does not intend to make any judgments as to the legal or other status of any territory or area.

This work is available under the Creative Commons Attribution 3.0 IGO license (CC BY 3.0 IGO) https://creativecommons.org/licenses/by/3.0/igo/. By using the content of this publication, you agree to be bound by the terms of this license. For attribution, translations, adaptations, and permissions, please read the provisions and terms of use at https://www.adb.org/terms-use\#openaccess.

This CC license does not apply to non-ADB copyright materials in this publication. If the material is attributed to another source, please contact the copyright owner or publisher of that source for permission to reproduce it. ADB cannot be held liable for any claims that arise as a result of your use of the material.

Please contact pubsmarketing@adb.org if you have questions or comments with respect to content, or if you wish to obtain copyright permission for your intended use that does not fall within these terms, or for permission to use the ADB logo.

Notes:

In this publication, “\$” refers to United States dollars.

ADB recognizes "China" as the People's Republic of China, "USA" as the United States, and "Vietnam" as Viet Nam. Corrigenda to ADB publications may be found at http://www.adb.org/publications/corrigenda. 


\section{Contents}

Tables, Figures, and Boxes $\mathrm{v}$

Acknowledgments viii

Abbreviations $\quad$ ix

Glossary xi

I. Introduction 1

A. Vision 1

B. Purpose 2

C. Rationale 2

D. Policy-Setting 3

E. Health Impact Assessment Practices 10

in Other Multilateral Development Banks and Elsewhere

F. Scope 13

G. How the Sourcebook Is Organized 13

H. Cross-Reference to Other Sourcebooks 13

II. Definition of Health and Safety 15

$\begin{array}{ll}\text { A. Introduction } & 15\end{array}$

B. Definition of Health 16

III. Definition of Health Impact Assessment 26

A. The Health Impact Assessment Process $\quad 27$

B. Kinds of Health Impact Assessment $\quad 27$

C. What Health Impact Assessment Is and Is Not 29

D. Opportunities and Concerns 29

IV. Integration with Bank Procedures 31

A. Health in Environmental Impact Assessments 32

B. Administrative Issues 34

$\begin{array}{lll}\text { V. Screening and Classification } & 37\end{array}$

A. Screening 37

B. Examples of Screening Urban Development Projects for Health 42

C. Health Classification 49

VI. Scoping 51

A. Opportunities and Concerns $\quad 52$

B. Priority Health Concerns by Sector 53

C. Communities 60

D. Setting Boundaries 64 
$\begin{array}{lr}\text { VII. Terms of Reference } & 67\end{array}$

$\begin{array}{lr}\text { VIII.Health Baseline } & 68\end{array}$

A. Health Statistics $\quad 68$

B. Community Consultation and Social Surveys 71

IX. Applicable Policy, Legal, and Administrative Framework and Standards 74

A. Harmonization in Transboundary Projects 74

$\begin{array}{ll}\text { X. Impact Analysis } & 76\end{array}$

$\begin{array}{ll}\text { A. Quantification } & 78\end{array}$

B. Questions to Ask $\quad 79$

C. Cumulative Impacts $\quad 79$

D. Associated Assessments 83

$\begin{array}{lr}\text { XI. Mitigation and Enhancement Measures } & 87\end{array}$

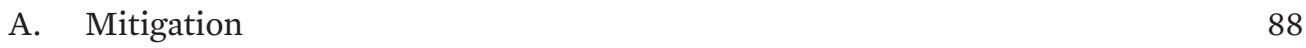

B. Enhancement $\quad 89$

C. Multiple Barriers $\quad 91$

D. Healthy Engineering Design $\quad 91$

$\begin{array}{lr}\text { XII. Appraisal } & 94\end{array}$

$\begin{array}{ll}\text { XIII.Public Health Management Plan } & 97\end{array}$

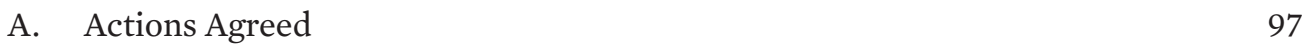

B. Monitoring Plan 99

$\begin{array}{lr}\text { XIV. Implementation } & 102\end{array}$

$\begin{array}{lr}\text { XV. More Information } & 103\end{array}$

A. Books and Guides 103

Appendixes

$1 \quad$ Communicable Disease in Infrastructure Development Including 104 Vector-Borne Diseases

2 Rapid Health Impact Assessment Scoping Template 126

3 Health Impact Assessments Terms of Reference 134

4 Construction Safety Checklist $\quad 148$

$5 \quad$ Evaluation Guide for Health Impact Assessments 155 


\section{Tables, Figures, and Boxes}

\section{Tables}

1 Summary of Key Sustainable Development Goals That Affect Health Determinants 5

2 Summary of National Health Impact Assessment Implementation Plans by Country 9 in the Greater Mekong Subregion

3 Summary of Health Impact Assessment Practices in ADB Comparator Institutions 10

4 Other ADB Sourcebooks 14

5 Examples of Health Outcomes That May Be Changed by Infrastructure Projects 17 in Key Sectors

6 Examples of Negative and Positive Changes in Health Outcomes by Sector 18

7 Examples of Negative and Positive Changes in Health Determinants by Sector 21

8 Health Determinants: Categories, Subcategories, and Examples 23

9 Examples of Environmental Impact Assessment Chapters in a Highway Project 33 and Potential Associated Health Outcomes

10 Resources Required for Two Levels of Assessment 34

11 Competency Framework for Health Impact Assessment Practitioners 36

12 Additions to Rapid Impact Assessment Questions on Project Siting 38

13 Additions to Sector-Specific Rapid Environmental Assessment Questions 39

14 Suggested Screening Questions for Health Infrastructure Projects 40

15 Projects with Explicit Health Objectives 41

16 Examples of Positive and Negative Health Outcomes Associated 43 with Urbanization and Urban Projects

17 Examples of the Environmental and Social Determinants of Health 43 That May Be Affected by Urban Projects

18 Examples of the Urban Health Outcomes of Climate Change

9 Healthy Urban Design Unit Checklist for Urban Planning 45

20 Examples of Urban Communicable Diseases 46

21 Examples of Urban Noncommunicable Diseases $\quad 47$

22 Other Urban Health Issues 47

23 Other Components of the Urban Environment That Are Critical for Health 48

24 Key Health Questions for Urban Projects, Operational Stage 49

25 Health Classification $\quad 50$

26 Water and Sanitation 54

27 Energy

28 Transport 57

29 Urban Development 59

30 Agricultural Development and Irrigation 60

31 Primary and Secondary Functions of Health Baselines 68

32 Examples of Health Baseline Conditions That Might Be Found 69 in a Poor Community 
33 Example of the Elements of a Simple Summary Impact Table 77

34 Example of the Elements of a Residual Risk Analysis $\quad 78$

35 Examples of Quantification of Health Outcomes $\quad 79$

36 General Health Questions During Construction Phase $\quad 81$

37 Some Health Impacts of Climate Change 83

38 Health Challenges and Impacts of Resettlement 85

39 Health Impacts and Management Measures for Influx 86

40 The Health Mitigation Hierarchy and Two Examples 88

41 The Health Benefit Hierarchy with Examples 90

42 Examples of Healthy Engineering Design Considerations 93

43 Example of Simple Public Health Management Plan Components 99

44 Example of Types of Health Monitoring $\quad 100$

45 Examples of Health Indicators by Sector 101

\section{Figures}

1 Overview of the Obesity System Influence $\quad 19$

2 Depiction of Health Outcomes and Health Determinants as 5-3 Model 22

3 Causal Diagram Indicating the Changes in Health Determinants Associated 25 with Health Benefits of the Mandalay Urban Services Improvement Project in Myanmar

4 Changes in Health Determinants 26

5 Overview of Health Impact Assessment Procedure and Method 28

6 From Scoping and Analysis to a Public Health Management Plan 30

$7 \quad$ Health Issues Addressed in Environmental Impact Assessment and Poverty 38 and Social Assessment Screening Practices at the Asian Development Bank

8 Output of Screening for Health Concerns

9 Example of Socioeconomic Status and Community Health 62

10 Average Life Expectancy at Birth Versus National Income per Capita 62

11 A Healthy and Sustainable Engineering Design Procedure

\section{Boxes}

1 An Urban Water Supply Project in India 6

2 The Cost of Air Pollution in the Asia and Pacific Region $\quad 7$

3 Rice Irrigation, Pigs, and Japanese Encephalitis: The Cost of Outbreaks 8 in Sri Lanka

4 Health Impact Assessment of an Agricultural Project in India 20

5 Perception-Related Behavior Change $\quad 20$

6 Air Quality and Health $\quad 31$

7 Curriculum Development in Greater Mekong Subregion Universities 36

8 A Health Impact Assessment of a Very Large Sewer Project in England 52

9 Health Impact Assessment of a Flood Action Plan in Bangladesh 53

10 Nam Theun 2 Hydropower Project in the Lao People’s Democratic Republic $\quad 56$

11 Eindu to Kawkareik Road Improvement Project, Myanmar 58

12 Scoping a Highway $\quad 65$

13 Health Impact Assessment of a Large Industrial Project in the People's 70 Republic of China

14 Primary Data Collection for the Health Impact Assessment of a Gas Plant 70 in a Pakistan Desert 
15 Community Survey of Health Concerns Associated with a Waste-To-Energy Project 72 in England

16 Health Impact Assessment of a Large Industrial Project in a Water-Poor Region 78 of the Middle East

17 Quantifying the Health Costs of Air Pollution 80

18 Cumulative Health Impacts of Special Economic Zones 84 in the Greater Mekong Subregion

19 Resettlement Mismanagement and Indigenous People 86

20 Activated Sludge Treatment Plant in Syria $\quad 87$

21 Unsustainable Mitigation $\quad 89$

22 A Health Impact Assessment of Social Housing Redevelopment in England 90

23 Control of Dengue Vectors in Viet Nam by Repeated Actions 91

24 Health Impact Assessment of a Suburban Housing and Bypass Project in England 94

25 Procurement of Services $\quad 95$

26 Appraisal of the Health Component of the Social Assessment and Social 96 Management and Monitoring Plan of Don Sahong Hydropower Project, Lao People's Democratic Republic

27 Public Health Action Plan of Nam Theun 2 Hydropower Project 98

28 Health Indicators Proposed for the Mandalay Urban Services 101 Improvement Project 


\section{Acknowledgments}

The Health Impact Assessment Sourcebook was developed by a team of experts, led by Susann Roth. We gratefully acknowledge the contributions of the lead consultant Martin Birley as the main author and Genandrialine Peralta as the co-author. The document was developed in close consultation and with inputs from other health impact assessment specialists Robert Bos, Salim Vohra, Yanyong Inmuong, Filipe Silva, Janis Shandro, Liza Tabora, Helen Brown, Jeffery Spickett, and Dianne Katscherian along with technical editing from Terrence Thompson, Luisa Veran, Loida Casaclang, Lydia Domingo, Veronica Birley, and Astrud Lea Beringer.

We thank all contributors for making this document practical and useful. Several regional and national consultation workshops were held in ADB and Greater Mekong Subregion Developing Member Countries to inform the Sourcebook. The ADB Environmental Safeguards team provided valuable comments and suggestions and ensured relevance in the ADB context, especially Bruce Dunn, Emma Marsden, Francesco Ricciardi and Nessim J. Ahmad. The document was edited and designed by Wickie Mercado, Keisuke Taketani, and Principe Nicdao with administrative support from Honey May Manzano-Guerzon. 


\section{Abbreviations}

\begin{tabular}{|c|c|}
\hline ADB & Asian Development Bank \\
\hline ASEAN & Association of Southeast Asian Nations \\
\hline ASEAN - OSHNET & ASEAN - Occupational Safety and Health Network \\
\hline CHS & community health and safety \\
\hline $\mathrm{CO}_{2}$ & carbon dioxide \\
\hline DMC & developing member country \\
\hline EIA & environmental impact assessment \\
\hline ESIA & environmental and social impact assessment \\
\hline ESHIA & environmental, social, and health impact assessment \\
\hline GDP & gross domestic product \\
\hline GHG & greenhouse gas \\
\hline GMS & Greater Mekong Subregion \\
\hline HACCP & hazard analysis critical control point \\
\hline HIA & health impact assessment \\
\hline IAIA & International Association for Impact Assessment \\
\hline ICMM & International Council on Mining and Minerals \\
\hline IFC & International Finance Corporation \\
\hline ILO & International Labor Organization \\
\hline IPIECA & $\begin{array}{l}\text { International Petroleum Industry Environmental } \\
\text { Conservation Association }\end{array}$ \\
\hline IPSA & initial poverty and social analysis \\
\hline ISO & International Standard Organization \\
\hline ITN & insecticide-treated net \\
\hline MDB & multilateral development bank \\
\hline MDG & Millennium Development Goal \\
\hline MOE & Ministry of Environment \\
\hline MONRE & Ministry of Natural Resources and Environment \\
\hline $\mathrm{MOH}$ & Ministry of Health \\
\hline $\mathrm{NO}_{\mathrm{x}}$ & nitrogen oxide \\
\hline $\mathrm{OHS}$ & occupational health and safety \\
\hline OHSAS & Occupational Health and Safety Series \\
\hline $\mathrm{OPH}$ & operational plan for health \\
\hline PEEM & Panel of Experts on Environmental Management \\
\hline PHMP & public health management plan \\
\hline $\mathrm{PM}_{2.5}$ & particulate matter of less than 2.5-micron diameter \\
\hline $\mathrm{PM}_{10}$ & particulate matter of less than 10-micron diameter \\
\hline PPMS & project performance management system \\
\hline PSA & poverty and social analysis \\
\hline REA & rapid environmental assessment \\
\hline RST & rapid scoping template \\
\hline
\end{tabular}


SDG

$\mathrm{SO}_{2}$

SPS

STI

TOR

WHO
Sustainable Development Goal

sulfur dioxide

safeguards policy statement

sexually transmitted infection

terms of reference

World Health Organization 


\section{Glossary}

\begin{tabular}{ll} 
Term & \multicolumn{1}{c}{ Definition } \\
Arbovirus & Arthropod-borne virus such as dengue fever. \\
Brackish & Slightly salty. \\
\hline $\begin{array}{l}\text { Communicable } \\
\text { disease }\end{array}$ & $\begin{array}{l}\text { Any disease that is transmitted between humans or between animals } \\
\text { and humans via an agent or medium, such as insects, food, water, } \\
\text { direct contact, aerosol spray, or blood and blood-contaminated } \\
\text { materials. The disease-causing organisms are referred to as pathogens } \\
\text { and cause an infection. Examples are malaria, dengue, cholera, and } \\
\text { sexually transmitted infections. }\end{array}$ \\
\hline Community health \\
and safety & $\begin{array}{l}\text { The health and safety of a community. It includes communicable } \\
\text { diseases, noncommunicable diseases, injuries, nutritional disorders, } \\
\text { mental health and well-being. These may be changed by a } \\
\text { development action. Community health outcomes are mediated by } \\
\text { the determinants of health. }\end{array}$ \\
Building including excavation and the construction, structural \\
alteration, renovation, repair, maintenance (including cleaning and \\
painting and demolition or dismantling of all types of buildings and \\
structures).
\end{tabular}

1 WHO. 1948. Preamble to the Constitution of the World Health Organization as adopted by the International Health Conference. New York. 19-22 June 1946. Entered into force on 7 April 1948. 
Term Definition

Health,operational Health and safety includes all communicable diseases, definition for use noncommunicable diseases, injuries, nutritional disorders, mental in infrastructure illness, and well-being that may be changed by a development action. development These are mediated by the determinants of health.

Health determinant, The root causes of illness and well-being that may be individual, or determinant of social, or environmental. These are also referred to as risk and health protective factors.

Health impact A combination of procedures, methods, and tools by which a policy, assessment (HIA) program, or project may be judged as to its potential effects on the health of a population, and the distribution of those effects within the population. HIA identifies appropriate actions to manage these effects. $^{2}$

Health inequality Differences in health status, or in the distribution of health determinants between different population groups.

Health outcome Medically defined states of disease or disability, as well as community defined states of well-being. The main categories used in HIA are communicable diseases, noncommunicable diseases, injuries, nutritional disorders, mental health and well-being.

Health services, Prevention and curative care provided to the population normally health care or under the auspices of a national authority, such as the ministry of health system health. Services may be offered by private health care providers, government agencies, or both. The capacity of health services is one determinant of community health status; overall community health status is determined by the policies, programs, and projects of all sectors.

Infection

The invasion of the body by pathogenic microorganisms that multiply, and the reaction of the body to these microorganisms and the toxins they produce.

Insecticide-treated Improved bednet, mosquito net, or room net for protecting sleeping net people from mosquito bites. The chemical on the net actively repels hungry mosquitoes, even when there are gaps or holes.

Noncommunicable Any disease that cannot be transmitted between humans and is not disease usually an infection; root causes are exposure to pollutants, unhealthy behavior or lifestyle, stress, or genetics. Examples are hypertension, cancer, and diabetes.

Nutritional Caused by an insufficient intake of food or of certain nutrients, disorders by an inability of the body to absorb and use nutrients, or by overconsumption of certain foods. Examples include obesity caused by excess energy intake, and anemia caused by insufficient intake of iron.

Occupational health Refers to the health, safety, and welfare of people at work. and safety

2 R. Quigley et al. 2006. Health Impact Assessment International Best Practice Principles. 


\begin{tabular}{|c|c|}
\hline Term & Definition \\
\hline Pathogen & $\begin{array}{l}\text { A pathogen is a disease-causing organism, most commonly viruses, } \\
\text { bacteria, or parasites. }\end{array}$ \\
\hline Psychosocial & The psychological and social factors that influence mental health. \\
\hline Scoping & $\begin{array}{l}\text { Deciding what is to be included in and excluded from an impact } \\
\text { assessment; setting the boundaries for an assessment in time and } \\
\text { space and the community groups that are included; agreeing on key } \\
\text { assessment definitions, criteria, and methods. }\end{array}$ \\
\hline Screening & A process of sorting project proposals to ascertain the need for HIA. \\
\hline $\begin{array}{l}\text { Sexually } \\
\text { transmitted } \\
\text { infection }\end{array}$ & $\begin{array}{l}\text { Infections transmitted through sexual contact, such as HIV and } \\
\text { gonorrhea. }\end{array}$ \\
\hline Severance & $\begin{array}{l}\text { A physical barrier created by a transport or other development } \\
\text { project that creates a physical, social and psychological separation } \\
\text { for individuals and groups within a community or between } \\
\text { communities. }^{3}\end{array}$ \\
\hline $\begin{array}{l}\text { Social license to } \\
\text { operate }\end{array}$ & $\begin{array}{l}\text { The social license to operate is conferred by the community to the } \\
\text { project by enabling the project to proceed. It is lost when the local } \\
\text { community protest a project causing delays or cancellations. }{ }^{4}\end{array}$ \\
\hline Stable malaria & Malaria that is present most of the year. \\
\hline Unstable malaria & $\begin{array}{l}\text { Seasonal or significant variation in new case rates over time, } \\
\text { sometimes epidemics. }\end{array}$ \\
\hline
\end{tabular}

See also World Health Organization's Glossary of Terms Used in Health Impact Assessment. ${ }^{5}$

3 P. Anciaes. 2015. What do we mean by community severance?

4 B. Yates and C. Horvath. 2013. Social License to Operate: How to Get It, and How to Keep It. In: National Bureau of Asian Studies.

5 WHO. Glossary of terms used in Health Impact Assessment. 



\section{Introduction}

\section{Summary}

- The vision, purpose, rationale, and policy-setting of health impact assessments are introduced and linked to the Sustainable Development Goals.

- The economic costs and benefits of investing in health are discussed.

- The health impact assessment policies of some countries, other multilateral development banks, and the World Health Organization are compared.

- The links between this sourcebook and other Asian Development Bank sourcebooks are explained.

\section{A. Vision}

(i) The Asian Development Bank (ADB) is committed to ending poverty in the Asia and Pacific region. ADB's Strategy 2020 was formulated at a time when the Millennium Development Goals (MDGs) provided an overarching framework for international development. ${ }^{1}$ At the time of the strategy's publication, a number of challenges were identified, including the following: Poverty remains the central challenge facing the region;

(ii) Disparities in well-being are widening within and between the bank's developing member countries (DMCs);

(iii) Rapid economic growth is putting severe strains on the environment;

(iv) Lack of infrastructure is constraining market-led growth and access to social services in many countries;

(v) More regional cooperation and integration is needed to address DMCs' challenges and opportunities.

1. The period of implementation of this strategy will soon come to a close. Undeniably, great progress in poverty eradication has been made in the Asia and Pacific region. Meanwhile, the international development community has transitioned from the MDG to the Sustainable Development Goal (SDG) framework, with a greater emphasis on transformative change to strengthen the economic, social, and environmental pillars of sustainability, and with an even greater emphasis on inclusiveness. ${ }^{2}$

2. Some things, however, have not changed. Poverty remains a debilitating phenomenon in many DMCs. And on the flipside of the poverty coin, ill-health continues to play a critical

1 ADB. 2008. Strategy 2020: Working for an Asia and Pacific Free of Poverty. Asian Development Bank 2008-2020. Manila.

2 Anonymous. Sustainable Development Goals: Sustainable Development Knowledge Platform. 
role in putting a brake on equitable and sustainable development. Poverty breeds ill-health, and disease, disability, and premature death help maintain poverty. They need to be tackled in tandem. Progress in community health status cannot be the sole responsibility of the health sector. Thinking about health in development requires the engagement of all sectors at all levels. Development planning needs to consider all options to protect and promote human health at the earliest possible stages. In doing so, it serves the economic strength of national development (preventing the transfer of hidden costs to the health sector), the social face of development (protecting vulnerable groups), and the sustainability of development (no sustainable projects without a healthy human resource base). As Strategy 2020 states:

It is now apparent that not only the pace of growth but the pattern of growth matters.

\section{B. Purpose}

3. The primary purpose of this sourcebook is to provide up-to-date information to ADB environmental safeguards, poverty and social analysis, and compliance staff to support the process of health impact assessment (HIA). This sourcebook may also be a useful reference for other ADB staff, borrowers, and clients, executing agencies, consultants, and other public health practitioners, including nongovernment organizations and members of civil society.

4. HIA is a combination of procedures, methods, and tools that systematically judges the potential effects of a policy, plan, program, or project on the health of a population and the distribution of those effects within the population. HIA identifies appropriate actions to manage those effects. ${ }^{2}$ Its outputs are an HIA report and a public health management plan (PHMP).

5. This sourcebook adds a number of concepts to the way human health is addressed in the existing environmental safeguards and poverty and social analysis frameworks already applied by ADB. These concepts include

(i) considering human health more comprehensively (communicable diseases, noncommunicable diseases, nutritional disorders, injuries and accidents, and psychosocial disorders);

(ii) using a balanced approach toward identifying health benefits and health risks, with the associated recommendations to promote health and health protective measures; and

(iii) focusing on the determinants of health and how these are modified by development, rather than on disease outcomes.

\section{Rationale}

6. The rationale for an "upstream" approach to health in development is based on arguments of economics, social justice, and good governance. The approach

(i) minimizes the transfer of hidden costs (arising from increased diseases burdens) to the health sector; 
(ii) optimizes the potential for cost-effective health interventions by considering a maximum of options (including design and project management);

(iii) recognizes health co-benefits as a matter of social responsibility and a contribution to project viability;

(iv) leverages successful health outcomes as part of a project by incorporating them into economic evaluation;

(v) enhances synergies between assessment procedures (environmental safeguards and poverty and social analyses);

(vi) promotes good governance-focused on vulnerability and social justice-on poverty reduction and on compensation for involuntary risk-taking; and

(vii) promotes resilience and sustainability-a sustainable project needs a healthy human resource base.

\section{Policy-Setting}

7. $\mathrm{ADB}$ aims to optimize the community health outcomes of the development projects that it supports. For example, the Operational Plan for Health 2015-2020 (OPH) confirms that $\mathrm{ADB}$ will continue to advocate and advise infrastructure initiatives to optimize health outcomes. ${ }^{3}$ It will promote cross-sectoral collaboration through the use of improved assessment approaches, enabling $A D B$ to use its impressive presence in infrastructure to better account for the contribution of non-health sectors to health outcomes and to mitigate possible adverse health impacts of infrastructure projects.(footnote 3 ).

8. The OPH identifies HIA as an instrument for implementing this strategy. The ADB Safeguard Policy Statement (SPS) affirms that safeguarding health as part of environmental and social sustainability is a cornerstone of economic growth and poverty reduction. ${ }^{4}$ The goal of the policy is to protect both the natural environment and people from the potential adverse impacts of infrastructure development projects. The ADB Safeguards Policy and Good Practice Sourcebook states that local communities must be protected from projectrelated hazards. ${ }^{5}$ Project-related activities may directly, indirectly, or cumulatively, change community exposure to hazards. Communicable diseases are a significant concern. These include malaria and sexually transmitted infections (STIs) among others. Noncommunicable diseases include different types of cancers, acute and chronic cardiovascular diseases, diabetes, and other endocrinal disorders, and chronic respiratory health problems.

9. The ADB SPS explicitly recognizes the importance of community and occupational health and safety. It does so by having a section on community health and safety and stating that the borrower/client and the environmental assessment:

... will consider all potential impacts and risks of the project on physical, biological, socioeconomic (occupational health and safety, community health and safety, vulnerable groups and gender issues), and impacts on livelihoods through environmental media ... and physical cultural resources in an integrated way. (pp. 31 and $\left.38^{4}\right)$.

3 ADB. 2015. Operational Plan for Health, 2015-2020. Manila.

4 ADB. 2009. Safeguard Policy Statement. Manila.

5 ADB. 2012. Environment Safeguards: A Good Practice Sourcebook (Draft Working Document). Manila. 
10. ADB is committed to the principle of "do no harm." This includes a commitment to poverty reduction and social justice; and to the principle that the most vulnerable members of society require the most protection. There is a strong reciprocal link between socioeconomic status and health. The health impacts of a project are often unevenly distributed between different community groups. Average effects do not provide a realistic picture of whose health benefits and whose health is harmed. Trade-offs do not justify disproportionate ill-health effects for vulnerable community groups. HIA is a tool for disentangling health impacts "upstream," ensuring that the most vulnerable have both the health protection and opportunity that a project offers.

11. HIA is the key systematic approach used internationally as a tool to understand and manage the nature and distribution of the community and occupational health and safety impacts of all types of projects. It also helps to identify existing health assets and coping strategies-the resources and opportunities within affected communities that protect and improve health and well-being. These make communities more resilient to any potential adverse effects of projects and more able to benefit from the opportunities that a project brings.

\section{Sustainable Development Goals and Health}

12. ADB is committed to environmentally sustainable growth and regional integration. Infrastructure development cannot be sustainable if human health is damaged. Conversely, development that includes health gains is likely to be more sustainable. ADB is also committed to supporting the SDGs. In September 2015, heads of states adopted the SDG framework at a special session of the United Nations General Assembly (footnote 2). The target date for achieving the SDGs is 2030. Community health is explicitly recognized under SDG 3: "Ensure healthy lives and promote well-being for all at all ages."

13. There are 13 targets under SDG 3 . The six most relevant to community health in development are:

(i) SDG3.3: By 2030, end the epidemics of AIDS, tuberculosis, malaria and neglected tropical diseases and combat hepatitis, water-borne diseases and other communicable diseases.

(ii) SDG3.9: By 2030, reduce the number of deaths and illnesses from hazardous chemicals and air, water and soil pollution and contamination.

(iii) SDG3.4: By 2030, reduce by one third premature mortality from noncommunicable diseases through prevention and treatment and promote mental health and well-being.

(iv) SDG3.6: By 2020, halve the number of global deaths and injuries from road traffic accidents.

(v) SDG3.8: Achieve universal health coverage.

(vi) SDG3.d: Strengthen the capacity of all countries, in particular developing countries, for early warning, risk reduction and management of national and global health risks.

14. Other SDGs cover a range of key environmental and social determinants of health such as food security and nutrition, access to water, sanitation, and clean energy, good quality built environments, sustainable transport, and road safety, among others (Table 1). 
Table 1: Summary of Key Sustainable Development Goals That Affect Health Determinants

\begin{tabular}{|c|c|}
\hline SDG & Summary \\
\hline 6 & Ensure availability and sustainable management of water and sanitation for all \\
\hline 7 & Ensure access to affordable, reliable, sustainable and modern energy for all \\
\hline 9 & $\begin{array}{l}\text { Build resilient infrastructure, promote inclusive and sustainable industrialization and foster } \\
\text { innovation }\end{array}$ \\
\hline 11 & Make cities and human settlement inclusive, safe, resilient and sustainable \\
\hline 12 & Ensure sustainable consumption and production patterns \\
\hline 13 & Take urgent action to combat climate change and its impacts \\
\hline 15 & $\begin{array}{l}\text { Protect, restore and promote sustainable use of terrestrial ecosystems, sustainably manage } \\
\text { forests, combat desertification, and halt and reverse land degradation and halt biodiversity loss }\end{array}$ \\
\hline
\end{tabular}

15. In addition to the SDG 3 indicators, the World Health Organization (WHO) is formally monitoring health-related indicators for some of these SDGs such as access to safe drinking water and sanitation, child malnutrition, household use of clean fuels, and violence and related deaths. The potential for HIA to support the achievement of additional health co-benefits of development actions that focus on achieving other SDG targets is significant. HIA will help mobilize other development sectors, including the private sector, to work beyond SDG 3 and protect, promote, and improve community health, safety, and well-being.

16. HIA provides an opportunity for assessing the contribution of ADB funded projects to these health-related SDG targets; and mobilizing other resources to protect and improve the health of project-affected communities.

\section{Economic Benefits and Costs}

17. HIA helps project proponents to identify where changes to project design or operation will provide health benefits and mitigate health risks. This adds substantial economic value to projects, to the health sector, and national economies as a whole.

\section{a. Benefits}

18. The economic benefit of investing in health has been demonstrated in many settings. For example:

(i) An additional $\$ 5$ per person per year invested in health expenditure in low-income countries could yield a benefit-to-cost ratio of up to $9: 1 ;^{6}$

(ii) A $10 \%$ reduction in malaria prevalence rates is associated with $0.3 \%$ increase in national economic growth (gross domestic product per capita); ${ }^{7}$

6 K. Stenberg et al. 2014. Advancing Social and Economic Development by Investing in Women's and Children's Health: A New Global Investment Framework. The Lancet. 383 (9925). pp. 1333-54.

7 J Gallup and J. Sachs. 2001. The Economic Burden of Malaria. Am J Trop Med Hyg. 64 (1-2 Suppl). pp. 85-96. 
(iii) The health-related societal cost of air pollution has been estimated at about twice the cost of regulatory mitigation and the consequent costs to consumers and businesses; ${ }^{8}$

(iv) The cost-benefit ratio for the necessary interventions to attain universal access to sanitation in the Asia and Pacific region varies from 4.6 in South Asia to 8.0 in East Asia; ${ }^{9}$ and

(v) Vaccination against Japanese encephalitis can be cost-effective. In one economic evaluation, a cost of $\$ 434,898$ per year yielded a saving of $\$ 1,591,975$ for the health system and $\$ 11,570,989$ for society, per 100,000 people..$^{10}$

\section{b. Costs}

19. One of the keys ideas in HIA is the transfer of hidden costs from other sectors to the health sector (Box 1 and Box 2). A failure to address the health impacts of infrastructure development can transfer economic and social costs from a project to the government health sector (Box 3). These costs are incurred by the increased demand for medical care and curative services, the need for an adequate response to a public health emergency, the loss of economic productivity through chronic illness, and the need for communities to bear the social costs of informal care for those who have disabilities and long-term health problems. The health sector is often under-resourced, so any additional costs become a significant longterm burden.

20. The community may carry the burden directly through out-of-pocket expenses. As these costs are often not acknowledged they are referred to as hidden costs or externalities.

\section{Box 1: An Urban Water Supply Project in India}

The project supplied piped drinking water into the homes of an urban coastal population in a location with a high water table. The project did not include adequate drainage. Open urban drains were blocked with solid waste. Construction of domestic wastewater disposal systems was left to the homeowners. Most households used pit latrines or emptied wastewater onto the street. The health impact assessment (HIA) noted that pit latrines and pooled wastewater were prolific breeding sites for the mosquito species transmitting filariasis. The HIA recognized that permanent improvements in waste management would require high level changes in urban planning, legislation, regulation, land tenure, and investment that were outside the scope of the project. The HIA explained that the hidden cost of filariasis control had been transferred to the health sector. The health sector provided indoor spraying of residual insecticides, insecticidetreated nets, polystyrene beads, clearance of open drains, and curative medicine.

Source: Sustainable Development and Climate Change Department, Asian Development Bank.

8 K. Crane and Z. Mao. 2015. Costs of Selected Policies to Address Air Pollution in China.

9 WHO. 2012. Global Costs and Benefits of Drinking-water Supply and Sanitation Interventions to Reach the MDG Target and Universal Coverage.

${ }^{10}$ Z. Yin et al. 2012. An Economic Evaluation of the Use of Japanese Encephalitis Vaccine in the Expanded Program of Immunization of Guizhou province, China. Vaccine. 30 (37). pp. 5569-77. 


\section{Box 2: The Cost of Air Pollution in the Asia and Pacific Region}

Two-thirds (69\%) of the global annual deaths linked to outdoor air pollution happen in the 48 regional member countries of the Asian Development Bank. This is estimated to be 2 million deaths a year, 200,000 of which are of children under- 5 years of age. These estimates are conservative as they only reflect deaths from exposure to particulate matter and not to other pollutants such as ozone or nitrogen dioxide. Twenty-nine member countries of the Asian Development Bank are seeing a rising trend in deaths due to outdoor air pollution $\left(\mathrm{PM}_{2.5}\right)$. Most development projects and associated activities give rise to atmospheric emissions that affect air quality and have human health consequences. Project-related air quality impacts are often assessed as part of environmental impact assessments (EIAs), which often thought to assess the health effects from changes to air quality. However, the focus of most air quality analyses in EIAs is on regulatory compliance-are national or World Health Organization air quality standards being breached? These analyses often overlook the fact that for most air pollutants, there is no known level (concentration threshold) below which they cease to influence human health. A health impact assessment (HIA) can complement the analyses undertaken in EIAs and translate the modelled changes in air quality into changes in the health risks for key health outcomes. HIA can provide a better understanding of environmental risks and can help to ensure that a more informed decision is taken.

Sources: Institute for Health Metrics and Evaluation. 2017. GBD Compare | IHME Viz Hub.; WHO. 2016. Ambient Air Pollution: A Global Assessment of Exposure and Burden of Disease; WHO. 2017. Global Health Observatory Data Repository; and WHO/EURO. 2013. Review of Evidence on Health Aspects of Air Pollution (REVIHAAP).

\section{Country Policies on Health Impact Assessment, Community Health, and Development}

21. ADB staff need to be aware that over the next decade, HIA, alongside or within environmental impact assessments (EIA), is likely to become a legislative and regulatory requirement in many of its DMCs and many types of projects. ADB held a multicountry consultation on the status of HIA guidelines in the Greater Mekong Subregion (GMS) in 2016. ${ }^{11}$ Table 2 shows a summary of the findings.

22. Despite these legislations, there are still multiple barriers to implementation in most countries. These include a need to strengthen collaboration between ministries of health, labor, and environment. ADB has the influence and convening power to resolve some of the key barriers.

\section{Influence and Convening Power}

23. Should it wish to do so, ADB can have a significant influence on health outcomes by placing health centrally within the objectives and performance indicators of all its projects, whether health or nonhealth sector. HIA is the ideal instrument for this. ADB has convening power, interdisciplinary approaches to regional health governance, and the ability to combine scientific evidence and technical knowledge with infrastructure investment policies and development finance. HIA can help demonstrate good governance.

${ }^{11}$ M. Birley et al. 2016. Multi-Country Consultation on Health Impact Assessment Guidelines. Bangkok. 


\section{Box 3: Rice Irrigation, Pigs, and Japanese Encephalitis: The Costs of Outbreaks in Sri Lanka}

The combination of irrigated rice production, pig rearing, and susceptible humans is the perfect recipe for periodic outbreaks of Japanese encephalitis. Japanese encephalitis is a viral disease carried by Culex tritaeniorrhynchis and Culex gelidus mosquitoes breeding in rice fields. It has a high under-5 mortality rate and leaves those recovered with important mental sequelae. Ardeid birds carry the virus over longer distances (and, as climate change also affect migratory bird flight patterns, into new areas) and pigs are the amplifying hosts for the virus. Normally these Culex mosquitoes prefer taking their bloodmeals from animals, so the transmission cycle remains restricted to pig populations. But when the mosquito population explodes (after heavy rains, or when rice fields are flooded at the start of the cropping season) their biting pattern becomes more indiscriminate and the virus spills over into the human population.

Such was the case by the mid-1980s in North Western province of Sri Lanka, wherein system H of the Accelerated Mahaweli Development Project infrastructure for irrigated rice culture was rapidly expanded, new population groups were settled in the area to start growing rice and the idea was implemented to strengthen these farmers' livelihood base by promoting pig raising as a secondary source of income. The new population had no immunity and major Japanese encephalitis outbreaks were the result.

The Sri Lankan health authorities had to lay out huge investments in expensive vaccination campaigns, at a time when delivery of the regular vaccine was cumbersome: two vaccinations with an interval of 1-4 weeks for infants aged over 6 months, and a third booster vaccination a year later (vaccines have since improved greatly). This placed a huge financial burden on the Ministry of Health. Death and disability among local communities suffered as a result of the outbreak-a dual cost in terms of money and ill-health. In this case, the environmental determinants (rice growing, pig raising), the social determinants (poor livelihoods leading to the promotion of pig raising as a secondary source of income) and individual determinants (no Japanese encephalitis immunity) are obvious. So are the economic benefits of managing risks on the basis of health impact assessment.

Sources: J. Peiris et al. 1992.

Japanese Encephalitis in Sri Lanka-The Study of An Epidemic: Vector Incrimination, Porcine Infection and Human Disease. Trans R Soc Trop Med Hyg. 86 (3). pp. 307-313; and J. Peiris et al. 1993. Japanese Encephalitis in Sri Lanka: Comparison of Vector and Virus Ecology in Different Agro-Climatic Areas. Trans R Soc Trop Med Hyg. 87 (5). pp. 541-548. 
Table 2: Summary of National Health Impact Assessment Implementation Plans by Country in the Greater Mekong Subregion

\begin{tabular}{|c|c|}
\hline Country & Summary of HIA implementation \\
\hline Cambodia & $\begin{array}{l}\text { Under a } 2007 \text { Memorandum of Understanding between the MOH and the MOE, } \\
\text { a National Commission for Environment and Health was established, which } \\
\text { covers many HIA-relevant areas, though not explicitly HIA itself. An HIA policy } \\
\text { has been under preparation. The new draft EIA Law, pending in anticipation of the } \\
\text { approval of an overarching environmental code, discusses HIA in Section 5. The } \\
\text { MOE is responsible for community health impacts of infrastructure development } \\
\text { through the EIA process. A national EIA guideline based on principles of public } \\
\text { participation is under development by the MOE. The need for a national HIA } \\
\text { guideline has been recognized. }\end{array}$ \\
\hline $\begin{array}{l}\text { Lao People's } \\
\text { Democratic } \\
\text { Republic }\end{array}$ & $\begin{array}{l}\text { Issued a National Policy on HIA in 2006, with accompanying practitioner } \\
\text { guidelines drafted in } 2008 \text { and approved in 2010. There is also an EIA guideline in } \\
\text { which health is mentioned. }\end{array}$ \\
\hline Myanmar & $\begin{array}{l}\text { As of 2017, draft legislation in support of HIA is being prepared. There is a } 2012 \\
\text { Environmental Conservation Law and a } 2015 \text { EIA procedure. The } 2012 \text { law refers } \\
\text { to the need for environmental and social impact assessment. The } 2015 \text { procedure } \\
\text { refers to human health. The Public Health Law (1992) may need revision to refer to } \\
\text { HIA. Myanmar has recently approved new EIA legislation and has now moved on } \\
\text { to drafting a clause to be inserted into the new EIA legislation on how HIA should } \\
\text { be undertaken as part of EIA. An EIA guideline is being formulated. }\end{array}$ \\
\hline Thailand & $\begin{array}{l}\text { HIA policies are in place. There are three drivers-the first is health in EIA of } \\
\text { MONRE legal framework and this prescribes } 12 \text { proposed project types that require } \\
\text { an EHIA. The second driver is the National Health Act (2007) of Office of The } \\
\text { Prime Minister, which enables any affected community group to request an HIA } \\
\text { study of any past-present-future proposed development projects, programs, and } \\
\text { policies. This type of HIA aims to enable the community to learn health impacts } \\
\text { from development activities and propose correction measures to the government } \\
\text { for the existing and future development activities. The third is HIA of MOPH, this } \\
\text { focuses on building capacity of public health officers on HIA as well as developing } \\
\text { HIA specific guidelines available for use by both government and private sectors. } \\
\text { Three types of guidelines have been issued: the EHIA Guideline for EHIA of } \\
\text { MONRE, HIA Guideline for public policy development of the National Health } \\
\text { Commission under the National Health Act, and Sector-based (specific) HIA } \\
\text { Guidelines by the MOPH. }\end{array}$ \\
\hline Viet Nam & $\begin{array}{l}\text { Has a Law on Prevention and Control of Infectious Diseases (2007) that requires } \\
\text { HIA for the sectors: industrial zones, urban areas, centralized residential areas, } \\
\text { and healthcare facilities. Draft technical guidelines on health impact assessment } \\
\text { for development projects were issued by the MOHs in } 2012 \text { and translated into } \\
\text { English in 2016. These contain a list of } 59 \text { project types requiring HIA. The law on } \\
\text { environmental protection (2014) requires inclusion of public health in EIA reports. }\end{array}$ \\
\hline
\end{tabular}

EHIA = environmental health impact assessment, EIA = environmental impact assessment, HIA = health impact assessment, $\mathrm{MOE}=$ Ministry of Environment, $\mathrm{MOH}=$ Ministry of Health, MONRE = Ministry of Natural Resources and Environment, $\mathrm{MOPH}=$ Ministry of Public Health.

Source: Sustainable Development and Climate Change Department, Asian Development Bank. 


\section{E. Health Impact Assessment Practices in Other Multilateral Development Banks and Elsewhere}

24. Many of ADB's comparator institutions have adopted HIA practices (Table 3). The World Bank has also published a high-level comparative review of Multilateral Development Bank Safeguard Systems. ${ }^{12}$

\section{International Finance Corporation and the World Bank}

25. The World Bank Group has published guidance on HIA for both the private and public sector, through the International Finance Corporation (IFC) and the World Bank. The IFC has established a Sustainability Framework ${ }^{13}$ and the World Bank an Environmental

\section{Table 3: Summary of Health Impact Assessment Practices in ADB Comparator Institutions}

\begin{tabular}{|c|c|}
\hline Institution & Practice \\
\hline $\begin{array}{l}\text { World Bank Group including } \\
\text { International Finance } \\
\text { Corporation }\end{array}$ & $\begin{array}{l}\text { Approved a new environmental and social framework in } 2016 \text { and it is } \\
\text { due to be implemented by } 2018 \text {. } \\
\text { Performance Standard } 4 \text { addresses the client's responsibility to avoid } \\
\text { or minimize the risks and impacts to community health, safety, and } \\
\text { security that may arise from project related-activities. } \\
\text { Published a supplementary introduction to Health Impact Assessment } \\
\text { (HIA) to give good practice guidance. }\end{array}$ \\
\hline $\begin{array}{l}\text { Other Equator Principles } \\
\text { signatory banks }\end{array}$ & $\begin{array}{l}\text { Adopted the International Finance Corporation Performance Standards } \\
\text { for private sector lending as the Equator Principles. }\end{array}$ \\
\hline African Development Bank & Circulated a draft "Operational Requirements on Health" in 2016. \\
\hline $\begin{array}{l}\text { Inter-American Development } \\
\text { Bank and European Bank } \\
\text { for Reconstruction and } \\
\text { Development }\end{array}$ & Have held discussions and reviewed internal papers on HIA. \\
\hline Extractive Sector & $\begin{array}{l}\text { The trade associations of the oil and gas corporations, International } \\
\text { Petroleum Industry Environmental Conservation Association, and } \\
\text { mining and minerals corporations, International Council on Mining } \\
\text { and Metals, have published guidance. }\end{array}$ \\
\hline World Health Organization & $\begin{array}{l}\text { Issued general guidance on HIA both globally and in some regions. } \\
\text { Various projects with other agencies. }\end{array}$ \\
\hline $\begin{array}{l}\text { United States Agency for } \\
\text { International Development }\end{array}$ & $\begin{array}{l}\text { Supplementary guidance on emerging infectious diseases and HIA has } \\
\text { been drafted. }\end{array}$ \\
\hline
\end{tabular}

Sources: African Development Bank. 2016. Draft: Operational Safeguard Requirements on Health. Guidance on Safeguard Issues. Report No.: 2.x. p.63.; Equator Principles. 2016. Equator Principles.; International Finance Corporation. 2009. Introduction to Health Impact Assessment. Washington, D.C.; International Petroleum Industry Environmental Conservation Association. 2016. Health Impact Assessments.; Pan American Health Organization. 2013. Health Impact Assessment: Concepts and Guidelines for the Americas.; S. Vohra and M. Birley. Health Impact Assessment: Summary of the Good Practice Guidance. The International Council on Mining and Metals.; USAID. 2012. Proposed supplemental guidance to the IFC's introduction to Health Impact Assessments: Emerging Infectious Diseases and HIAs.; and WHO. 2015. Health Impact Assessment (HIA): Why use HIA?

${ }^{12}$ Himberg H. 2015. Comparative Review of Multilateral Development Bank Safeguard Systems.

${ }^{13}$ International Finance Corporation. 2017. IFC Sustainability Framework. 
and Social Framework. They are similar and include a policy on environmental and social sustainability, as well as performance standards on environmental and social sustainability. ${ }^{14}$ They set environmental and social standards for investment project financing. The World Bank Board of Directors approved a new environmental and social framework in $2016^{15}$ and it is due to be implemented by $2018 .^{16}$

26. Performance Standard 4 in the IFC and Environment and Social Standard 4 in the World Bank address the client's responsibility to avoid or minimize the risks and impacts to community health, safety, and security that may arise from project related-activities, giving due attention to vulnerable groups. Avoidance of adverse health impacts is prioritized. Standard 4 is designed to be read in conjunction with the other standards as they complement each other. The Standard includes statements about:

(i) Infrastructure and equipment design and safety,

(ii) Hazardous materials management and safety,

(iii) Ecosystem services,

(iv) Community exposure to disease,

(v) Emergency preparedness and response, and

(vi) Security personnel.

27. The World Bank Standard also includes (i) safety of services, and (ii) traffic and road safety.

28. IFC has published a supplementary introduction to HIA, which is intended to give good practice guidance. ${ }^{17}$ This document has three objectives:

(i) To present methodological approaches to assess and address potential community health impacts that might typically be encountered in the development or review of existing or future industrial projects;

(ii) To help develop the terms of reference (TOR) that may be needed to conduct the HIA;

(iii) To help ensure inclusion of health impact aspects in the social and environmental impact assessment process.

29. The steps in the HIA process recommended by IFC are like those in this ADB sourcebook. The major conceptual difference lies in the classification of health determinants. IFC refers to 12 Environmental Health Areas. These classification differences are unlikely to change the assessment of health impacts compared to the ADB model. Supplementary guidance on emerging infectious (communicable) diseases and HIA has been drafted by USAID. ${ }^{18}$ Other major banks have adopted the IFC Performance Standards for private sector lending as the Equator Principles. ${ }^{19}$

${ }^{14}$ International Finance Corporation. 2012. Performance Standards on Environmental and Social Sustainability.

${ }^{15}$ World Bank. 2016. World Bank Board Approves New Environmental and Social Framework.

${ }^{16}$ World Bank. 2016. The New Environmental and Social Framework Protecting the Poor and the Environment in Investment Projects.

${ }^{17}$ International Finance Corporation. 2009. Introduction to Health Impact Assessment.

${ }^{18}$ USAID. 2012. Proposed supplemental guidance to the IFC's introduction to Health Impact Assessments: Emerging Infectious Diseases and HIAs.

19 Equator Principles. 2016. Equator Principles. 


\section{Other Multilateral Banks}

30. Regional multilateral development banks (MDBs) such as the African Development Bank, the Inter-American Development Bank, and the European Bank for Reconstruction and Development have held discussions and reviewed internal papers on HIA. The African Development Bank circulated a draft Operational Requirements on Health in 2016. ${ }^{20}$ A similar set of health outcomes is defined, the determinants of health are categorized in a different manner, but the approach is otherwise similar.

\section{Private Sector Example}

31. The extractive sector has been proactive in establishing good HIA practice. It does so to protect its reputation and social license to operate, and to differentiate their services from those of their competitors. The HIA is usually integrated with environmental and social assessment and referred to as environmental and social impact assessment (ESIA) or environmental, social, and health impact assessment (ESHIA). The trade association of the oil and gas corporations, International Petroleum Industry Environmental Conservation Association (IPIECA), has published revised HIA guidance, highlighting the importance that the oil and gas sector attaches to assessing and managing community health impacts. ${ }^{21}$ The trade association of mining and minerals corporations, International Council on Mining and Metals (ICMM), published guidance on HIA in 2010 (footnote 12).

\section{World Health Organization}

32. WHO has issued general guidance on HIA both globally ${ }^{22}$ and in some regions. ${ }^{23}$ WHO has also engaged in joint initiatives on HIA and health safeguards with the Food and Agriculture Organization of the United Nations, United Nations Environment Programme, United Nations Centre for Human Settlements, and some MDBs. These include:

- Panel of Experts on Environmental Management (PEEM) $)^{24}$

- Healthy Cities ${ }^{25,26}$

- Health in Environmental Impact Assessment ${ }^{27}$

- Multilateral Development Banks ${ }^{28}$

${ }^{20}$ African Development Bank. 2016. Draft: Operational Safeguard Requirements on Health. African Development Bank. (Guidance on safeguard issues). Report No.: 2.x. p.63.

${ }^{21}$ International Petroleum Industry Environmental Conservation Association. 2016. Health impact assessments.

${ }^{22}$ WHO. 2015. Health Impact Assessment (HIA): Why use HIA?

${ }^{23}$ Pan American Health Organization. 2013. Health Impact Assessment: Concepts and Guidelines for the Americas.

${ }^{24}$ M. Birley. 1991. PEEM Guidelines for Forecasting the Vector-borne Disease Implications of Water Resources Development.

${ }^{25}$ WHO. Healthy Cities.

${ }^{26}$ WHO. Types of Healthy Settings.

${ }^{27}$ WHO. 2015. Health in Environmental Impact Assessment: Guidance for Project Proponents Commissioning Health Assessments within an EIA. World Health Organization. pp. 21.

${ }^{28}$ M. Pfeiffer. personal communication. 


\section{F. Scope}

33. This sourcebook provides guidance and tools to help ADB staff to comply with the SPS requirements to safeguard occupational and community health and safety. It does not establish or change policy. It provides further technical guidance and good practice examples to better enable ADB staff to optimize and safeguard community and occupational health and safety as set out in the SPS.

34. This sourcebook is based on ADB's existing expertise and experience in health assessment and management, and the international good practices adopted by the other development banks and the key international institutions described above. It updates ADB's two previous guidance documents on HIA published in $1992^{29}$ and $2003 .{ }^{30}$

35. The sourcebook is not a definitive and exhaustive reference. A range of useful guidance and tools have been developed by other institutions and provide complementary information. While intended primarily for the use of ADB staff, the sourcebook may also be a useful reference for borrowers, clients, executing agencies, and consultants and other public health practitioners, including nongovernment organizations and civil society in the Asia and Pacific region. It is a working document that will be updated periodically with feedback and lessons learned from the practical application of the sourcebook and experience of projects in protecting, promoting, and improving community and occupational health and well-being.

\section{G. How the Sourcebook Is Organized}

36. The sourcebook has 14 primary sections and several appendixes that elaborate on key areas. The sections follow the general format of other ADB sourcebooks and are listed in the table of contents. The sections guide the reader through the main steps of an HIA and these are similar to the steps in an EIA. There are also sections that define health and health impact together with key concepts such as health determinants. In addition, there are sections that summarize ADB policy and integration with other ADB procedures. No prior knowledge of public health is assumed on the part of readers and there is a glossary of terms at the beginning. Extensive references are cited throughout and listed in a bibliography at the end. Where possible the bibliography provides links to online sources.

\section{H. Cross-Reference to Other Sourcebooks}

37. The HIA sourcebook should be read in conjunction with the other ADB sourcebooks that are listed in Table 4 and can be found on the ADB website. The HIA sourcebook complements these by explaining how health and safety should be considered and assessed in more detail.

${ }^{29}$ M. Birley and G. Peralta. 1992. Guidelines for the Health Impact Assessment of Development Projects. Manila: Asian Development Bank. Environment Paper. pp. 11.

${ }^{30}$ G. Peralta and J. Hunt. 2003. A Primer on Health Impacts of Development Programs. Manila: Asian Development Bank. 
Table 4: Other ADB Sourcebooks

Sourcebook

Environment Safeguards:

A Good Practice

Sourcebook -Draft

Working Document 2012

\section{Relevance}

- Emphasizes the differences between occupational health safeguards and community health safeguards. Sets out the steps in the environmental impact assessment process. These steps are also used in the health impact assessment (HIA) process. Makes clear references to health but does not provide a detailed operational definition.

- The HIA sourcebook complements it by providing an operational definition of health and by explaining community health and safety assessment in more detail. It takes the assessment beyond safeguarding against risks, introducing the concepts of health opportunities, health co-benefits and health promotion.

Involuntary Resettlement Safeguards 2012

A Planning and Implementation Good Practice Sourcebook Draft Working Document

Indigenous Peoples Safeguards 2013

A Planning and Implementation Good Practice Sourcebook

- Explains the assessment of social impacts. Discusses and considers some determinants of health, including provision of medical care.

- The HIA sourcebook complements it by explaining health impact assessment, safeguards and opportunities in more detail and more comprehensively, such as malaria prevention.

- Indigenous peoples are also often the most vulnerable members of a community and often experience the least benefits and the most adverse health impacts. The indigenous peoples sourcebook ensures respect for identity, dignity, human rights, livelihood systems, cultural uniqueness, and traditional health beliefs.

- The HIA sourcebook clarifies why these are all health determinants.

Source: Sustainable Development and Climate Change Department, Asian Development Bank. 


\section{Definition of Health and Safety}

\section{Summary}

- Introduces a definition of health for use in HIAs commissioned by ADB

- Defines health outcomes and health determinants and explains how these are used in HIA

- Introduces five categories of health outcomes and three categories of health determinants that should be considered by development projects

- Provides examples of the potential positive and negative health impact of projects in key sectors

\section{A. Introduction}

38. Many ADB documents such as guidance and procedures documents, TORs, legal documents, and the OPH itself all refer to community health and safety (CHS) or occupational health and safety (OHS), but not necessarily with a clear or uniform understanding of the term health. The term is open to a variety of interpretations in different documents. Current usage in $\mathrm{ADB}$ environmental safeguard documents focuses on environmental hazards (footnote 5). The ADB Poverty and Social Analysis ${ }^{31}$ extensively covers issues such as resettlement, the rights of indigenous peoples, and community coherence, but without recognizing explicitly all the associated health issues. A clear understanding and consistent usage of the term health in all $\mathrm{ADB}$ documents would likely lead to more consistent understanding, consideration, and assessment of health issues and impacts.

39. The words medical and health are often used interchangeably but they mean different things. For a better understanding of HIA as an intersectoral planning tool, it is pertinent to distinguish between health services and health status. The provision of quality health services usually comes under the remit of the ministry of health-either it provides the health services itself or it regulates the provision of health services by other entities. Health services are primarily medical in nature, in other words, they are curative. Health services do, however, also include a preventive component, usually smaller in volume and with a disproportionally limited budget. This preventive component includes vaccination campaigns, the distribution of insecticide-treated nets, malaria prophylaxis, health promotion, engineering and administrative controls to reduce risks of injuries, epidemiological services, environmental and public health, and data collection and analysis. Community health status refers to the outcome of all health determinants, many under the control of sectors other than health, and of the preventive actions of the health system.

${ }^{31}$ ADB. 2012. Handbook on Poverty and Social Analysis: A Working Document. Manila. 
40. Environmental health provides a slightly broader view of what affects our health. This includes air quality, noise, water quality, and food safety. It involves sectors other than health, such as food, water, and energy. Within the health sector, environmental health departments tend to have a marginal position, resulting in limited budgets and less attractive career opportunities. This position does, however, make environmental health departments well-placed to interact with other sectors. Responsibility for links between the health sector and EIA practitioners and regulators tends to fall within the remit of these departments. The model of health that informs the HIA is considerably broader than medical services and environmental health.

\section{B. Definition of Health}

41. Health is a complete state of physical, social, mental, and spiritual well-being, and not merely the absence of disease and infirmity. This definition is taken from WHO's constitution, with one amendment-spiritual well-being was not included in the original WHO definition. ${ }^{32}$ The distinct and important contribution of spiritual well-being to human health is well-recognized across Asia, and merits inclusion here. However, for practical purposes this definition is too general and broad, and therefore HIA practitioners generally use a more operational version.

42. The operational definition of health and safety proposed for use by ADB in HIA and other documents is the following.

Health and safety includes all programs and activities that prevent or control communicable diseases, noncommunicable diseases, injuries, nutritional disorders, mental health, and well-being that may be changed by a development action. Development actions affect health outcomes in beneficial and adverse ways through their influence on health determinants.

43. The two key ideas are health outcomes and health determinants. These are each explained in the following two subsections.

\section{Health Outcomes}

44. Health outcomes are medically defined states of disease and disability, as well as community-defined states of well-being. Table 5 indicates the main categories of health outcomes that may be associated with ADB's infrastructure projects and includes examples in each key sector. Communicable or infectious diseases are caused by pathogens (diseasecausing microorganisms) and can be acquired from another person or animal or transmitted by an intermediate agent. The pathogen may be transmitted either directly (such as sexually transmitted infections) or via another medium such as food, water, soil, and vectors (such as mosquitoes). By this means, they can multiply and spread through a population. They have the potential to cause epidemics. Further information is in Appendix 1. Noncommunicable diseases, by contrast, are not transmitted from one person to another. They are caused by

${ }^{32}$ WHO. 1948. Preamble to the Constitution of the World Health Organization as adopted by the International Health Conference. New York. 19-22 June 1946. Entered into force on 7 April 1948. 
Table 5: Examples of Health Outcomes That May Be Changed by Infrastructure Projects in Key Sectors

\begin{tabular}{|c|c|c|c|c|c|}
\hline Sector & $\begin{array}{c}\text { Communicable } \\
\text { Diseases }\end{array}$ & $\begin{array}{c}\text { Noncommunicable } \\
\text { Diseases }\end{array}$ & Injury & $\begin{array}{l}\text { Nutritional } \\
\text { Disorders }\end{array}$ & $\begin{array}{l}\text { Mental Illness } \\
\text { and Well-being }\end{array}$ \\
\hline $\begin{array}{l}\text { Water supply } \\
\text { and sanitation }\end{array}$ & $\begin{array}{l}\text { Dengue, } \\
\text { filariasis, } \\
\text { diarrhea }\end{array}$ & $\begin{array}{l}\text { Arsenicosis, } \\
\text { Fluorosis } \\
\text { cardio-vascular } \\
\text { disease }\end{array}$ & $\begin{array}{l}\text { Skeletal } \\
\text { deformation } \\
\text { due to carrying } \\
\text { heavy water } \\
\text { loads }\end{array}$ & $\begin{array}{l}\text { Undernutrition, } \\
\text { micronutrient } \\
\text { disorders }\end{array}$ & Well-being \\
\hline $\begin{array}{l}\text { Water } \\
\text { Resources } \\
\text { development }\end{array}$ & $\begin{array}{l}\text { Malaria, } \\
\text { leptospirosis, } \\
\text { filariasis }\end{array}$ & & $\begin{array}{l}\text { Drowning, } \\
\text { crushing }\end{array}$ & Undernutrition & $\begin{array}{l}\text { Psychosocial } \\
\text { disorders } \\
\text { related to } \\
\text { resettlement }\end{array}$ \\
\hline $\begin{array}{l}\text { Thermal } \\
\text { energy }\end{array}$ & & $\begin{array}{l}\text { Cancer, heart } \\
\text { disease, asthma }\end{array}$ & Burns & & Well-being \\
\hline $\begin{array}{l}\text { Agriculture } \\
\text { and animal } \\
\text { husbandry }\end{array}$ & Zoonoses & $\begin{array}{l}\text { Pesticide poisoning, } \\
\text { heavy metal } \\
\text { poisoning }\end{array}$ & $\begin{array}{l}\text { Skeletal } \\
\text { deformation } \\
\text { due to manual } \\
\text { labor }\end{array}$ & $\begin{array}{l}\text { Obesity, wasting } \\
\text { and stunting, } \\
\text { micronutrient } \\
\text { deficiencies }\end{array}$ & Suicide \\
\hline Urban & Tuberculosis & $\begin{array}{l}\text { Cancer, heart } \\
\text { disease, asthma }\end{array}$ & $\begin{array}{l}\text { Heat-related } \\
\text { deaths } \\
\text { Interpersonal } \\
\text { violence }\end{array}$ & $\begin{array}{l}\text { Obesity } \\
\text { Diabetes }\end{array}$ & $\begin{array}{l}\text { Anxiety } \\
\text { Substance } \\
\text { abuse }\end{array}$ \\
\hline Transport & $\begin{array}{l}\text { HIV and other } \\
\text { STIs }\end{array}$ & $\begin{array}{l}\text { Chronic obstructive } \\
\text { lung diseases }\end{array}$ & $\begin{array}{l}\text { Road traffic } \\
\text { injury }\end{array}$ & Obesity & $\begin{array}{l}\text { Sleep } \\
\text { disturbance }\end{array}$ \\
\hline $\begin{array}{l}\text { Sewage } \\
\text { treatment }\end{array}$ & $\begin{array}{l}\text { Gastrointestinal } \\
\text { infections }\end{array}$ & & Drowning & & Well-being \\
\hline
\end{tabular}

STIs = sexually transmitted infections.

Source: Sustainable Development and Climate Change Department, Asian Development Bank.

external environmental and social factors, or by genetic inheritance. Many different health outcomes could be added to each cell of the table and this will also vary with the project context. Table 6 subdivides the health outcomes into positive (benefits), and negative (risks).

\section{a. Missing Health Impacts - Nutrition as an Example}

45. Some, but not all, of the potential health impacts of ADB projects are already captured by environmental assessments or social appraisals. Nutritional issues are an example of a potential gap in ADB impact assessment procedures as the determinants either do not fit into existing checklists or are dispersed between them. The design and operation of projects in several sectors can influence nutritional status, as the previous tables indicate.

46. Infrastructure projects can have both positive and negative impacts on human nutrition and the associated diseases. Nutritional issues can be divided broadly into undernutrition and overnutrition. These vary between community groups. For example, the wealthier part of a community may be overnourished and suffer from overweight, obesity, diabetes, and heart disease at the same time that the poorer part of the community is undernourished and suffering from underweight, childhood stunting and wasting, anemia, or micronutrient deficiencies such as goiter, or overweight as a result of a poorly balanced diet. In addition, relatively wealthy people may be undernourished because of a poorly balanced diet. 
Table 6: Examples of Negative and Positive Changes in Health Outcomes by Sector

\begin{tabular}{|c|c|c|}
\hline Sector & $\begin{array}{l}\text { Potential Negative Changes } \\
\text { (Risk Increases) }\end{array}$ & $\begin{array}{c}\text { Potential Positive Changes } \\
\text { (Benefit Increases or Risk Decreases) }\end{array}$ \\
\hline Water supply & Dengue, filariasis & Diarrhea \\
\hline Thermal energy & Cancer, heart disease, asthma & $\begin{array}{l}\text { Respiratory disease, injury, mental } \\
\text { well-being }\end{array}$ \\
\hline $\begin{array}{l}\text { Agriculture and } \\
\text { livestock }\end{array}$ & $\begin{array}{l}\text { Dizziness, death, suicide, zoonoses, } \\
\text { poisoning }\end{array}$ & Nutritional status \\
\hline Urban & $\begin{array}{l}\text { Cancer, dengue, filariasis, mental illness, } \\
\text { diabetes, obesity, chronic obstructive lung } \\
\text { diseases, tuberculosis, traffic injury }\end{array}$ & $\begin{array}{l}\text { Mental well-being, cardiovascular } \\
\text { fitness, nutritional status }\end{array}$ \\
\hline Transport & $\begin{array}{l}\text { Cardiovascular disease, chronic } \\
\text { obstructive lung diseases, obesity, mental } \\
\text { illness }\end{array}$ & $\begin{array}{l}\text { Mental well-being, cardiovascular } \\
\text { fitness, nutritional status, injury }\end{array}$ \\
\hline $\begin{array}{l}\text { Sewage } \\
\text { treatment }\end{array}$ & $\begin{array}{l}\text { Mental well-being, gastro-intestinal } \\
\text { infections }\end{array}$ & Diarrhea, filariasis \\
\hline
\end{tabular}

Source: Sustainable Development and Climate Change Department, Asian Development Bank.

There are interactions between communicable diseases and nutritional status. For example, parasitic infections can lead to an unhealthy loss of weight. Complex changes in population nutritional status occur as a result of urbanization and development. Rural communities can have diets that are balanced and high in vegetable fibers. As these communities move to urban environments their diets may become unbalanced with starches, complex fats and sugars leading to overweight, obesity, and associated diseases.

47. Obesity is important because there is a global epidemic ${ }^{33}$ and rates are rising in Asia. ${ }^{34}$ It affects the poor as well as the wealthy; childhood hunger can trigger adult obesity. Over 100 determinants-or causes-of obesity have been identified. These are captured on a system influence diagram. The diagram is complex and best viewed online and interactively. ${ }^{35}$ Figure 1 provides a simplified overview of the health determinants.

48. The seven principal health determinants in this figure are as follows. ${ }^{36}$

(i) Biology: An individual's starting point-the influence of genetics and ill health;

(ii) Activity environment: The influence of the environment on an individual's activitybehavior-for example a decision to cycle to work may be influenced by road safety, air pollution, or provision of a cycle shelter and showers;

(iii) Physical activity: The type, frequency, and intensity of activities an individual carries out, such as cycling vigorously to work every day;

(iv) Societal influences: The impact of society, for example the influence of the media, education, peer pressure, or culture;

\footnotetext{
33 A. Ramachandran et al. 2010. Rising Burden of Obesity in Asia. Journal of Obesity. 2010:e868573.

${ }^{34}$ WHO. 2016. Obesity.

${ }^{35}$ Shiftn. Obesity System Influence Diagram.

${ }^{36}$ Public Health England Obesity Knowledge and Intelligence team. Causes of Obesity.
} 


\section{Figure 1: Overview of the Obesity System Influence}

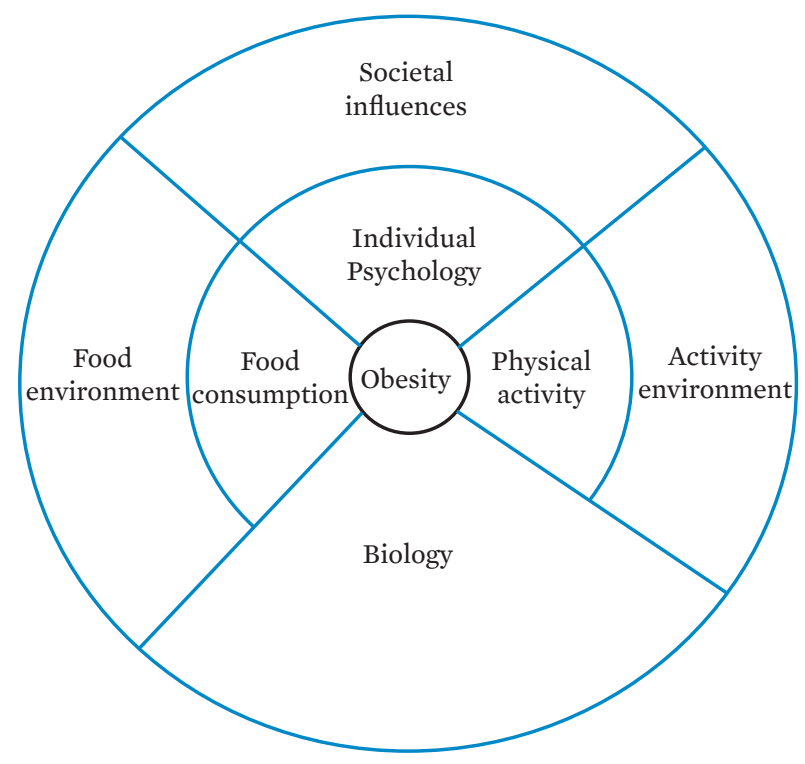

Source: Foresight systems map. 2007.

(v) Individual psychology: For example, a person's individual psychological drive for particular foods and consumption patterns, or physical activity patterns or preferences;

(vi) Food environment: The influence of the food environment on an individual's food choices, for example a decision to eat more fruit and vegetables may be influenced by the availability, affordability, and quality of fruit and vegetables near home;

(vii) Food consumption: The quality, quantity (portion sizes) and frequency (snacking patterns) of an individual's diet.

49. ADB's urban, agricultural, and transport projects may influence several of these determinants through design, construction, and operation. This is clearest in the urban environment where active transport such as walking and cycling can be promoted by parks, quiet-ways, stairs, bridges, underpasses, and cycle lanes. Active transport can be hindered by obstacles such as railway lines, embankments, cuttings, and highways. Access to healthy foods can be affected by marketplaces, fast food outlets, and supermarket locations. Agricultural projects that change economic activity from subsistence to commercial crops can have complex impacts on nutritional status, ${ }^{37}$ as Box example 4 illustrates.

\section{b. Mental Health - Anxiety}

50. Mental health is a major public health issue that is greatly affected by resettlement, noise, disruption, urban design, and much else. Infrastructure projects can also create anxiety and uncertainty. The stakeholders of a development project can experience many changes

${ }^{37}$ K. Cleaver, N. Okidegbe, and E. De Nys. 2006. Agriculture and Rural Development: Hunger and Malnutrition. Washington DC: World Bank. pp. 18. 


\section{Box 4: Health Impact Assessment of an Agricultural Project in India}

A subsistence agricultural community was provided with a commercial irrigated rice growing scheme. As subsistence farmers, food crops had been grown and harvested by the women and children. The food was then cooked in the household and distributed to family members.

Under the commercial rice growing scheme, rice was mostly cultivated by women and children, but generally it was the male head of household who sold it in the market. The cash from the sale was in some instances used to purchase tobacco, alcohol, and similar products. Family food supplies had to be purchased, no longer grown. One of the key health impacts identified was an increased risk of unequal entitlements within the household leading to childhood malnutrition. Mitigating this impact requires input from social, poverty, gender, and health specialists.

Source: N. Ramachandran. 2006. Women and food security in South Asia.

in their mental health and well-being. Uncertainty and loss of control can contribute to anxiety, substance abuse, suicide, and domestic violence. Project affected communities may also perceive a risk to their own health-or someone else's-that seems strange to the project assessment team and engineers. These perceptions not only give rise to anxiety and stress, they also create obstacles to project delivery through collective anger, demonstrations, and legal challenges. Risk perception is a well-developed field of sociology, psychology, ${ }^{38}$ economics ${ }^{39}$ and anthropology. ${ }^{40}$ The following list summarizes some conclusions.

(i) A formal process of information, education, and communication associated with a project is unlikely to change the risk perceptions of a community.

(ii) Risk perception is subjective and based on earlier experiences and trusted informants (Box 5).

(iii) Perceived risks can give rise to anxiety and anger. These can lead to changes in mental health and well-being.

(iv) There will always be substantial differences in the risk perceptions made by project proponents and by some of the project-affected communities. The proponents are voluntary risk takers; most of the project-affected communities are involuntary risk receivers. Many people accept high voluntary risks but reject low involuntary risks.

\section{Box 5: Perception-Related Behavior Change}

The risk of a road traffic accident is much higher than the risk of an air or train accident, but many people perceive road travel as safer. After one plane crash, the number of excess deaths from the consequent road traffic accidents was observed to be similar to the number of deaths in the original tragedy. Railway infrastructure is likely to have a much lower health impact than highways.

Source: G. Gigerenzer. 2015. Risk Savvy, How To Make Good Decisions.

${ }^{38}$ P. Slovic. 2016. The Feeling of Risk: New Perspectives on Risk Perception.

39 A. Boholm. 2015. Anthropology and Risk.

${ }^{40}$ G. Gigerenzer. 2015. Risk Savvy, How To Make Good Decisions. 
(v) Whether a project is perceived as a hazard or an opportunity depends on the observer. Individuals who believe themselves powerful, and in control of their own destiny, rank hazards as being of lower importance. Individuals who believe themselves to be underprivileged or powerless rank the same hazards much higher.

(vi) We all evaluate risks using criteria like: voluntary or involuntary; affecting children or affecting adults; familiar or unfamiliar; risk of killing people one-by-one or in groups.

(vii) It is good practice to enable communities to take control of the risks that affect them. This includes consulting on and involving communities in development projects as well as getting them involved in monitoring impacts by providing monitoring reports, having independent monitoring by trusted third parties, or by enabling communities to monitor risk and impacts themselves by providing them with monitoring equipment.

\section{Health Determinants}

51. Health outcomes can arise from policies or actions by any sector through a variety of mechanisms, illustrated in Table 7. These mechanisms are called health determinants.

52. The determinants of health can be categorized in many ways. One simple way is to distinguish those that can be changed by an infrastructure project from those that cannot. The operational categories are intended to fit within the ADB themes, sectors, and procedures while remaining consistent with WHO classifications. ${ }^{41}$ There are three categories of health determinants, and each has several subcategories. ${ }^{42}$ Figure 2 is a graphic illustration of the concept. It is adapted from WHO (footnote 22) and earlier sources (footnote 29). ${ }^{43}$

\section{Table 7: Examples of Negative and Positive Changes in Health Determinants} by Sector

\begin{tabular}{|c|c|c|}
\hline Sector & Negative Changes & Positive Changes \\
\hline Water supply & $\begin{array}{l}\text { Dengue vectors breeding in } \\
\text { water containers }\end{array}$ & Safe drinking water \\
\hline Thermal energy & Increase in stack emissions & Electric power in the home \\
\hline Agriculture & $\begin{array}{l}\text { Intended and unintended } \\
\text { pesticide poisoning }\end{array}$ & Enhanced food security \\
\hline Urban & Heat islands & $\begin{array}{l}\text { Active travel, quality of public realm, improved } \\
\text { air quality }\end{array}$ \\
\hline Transport & $\begin{array}{l}\text { Traffic congestion } \\
\text { and pollution }\end{array}$ & Modal shift toward public transport, active travel \\
\hline $\begin{array}{l}\text { Sewage } \\
\text { treatment }\end{array}$ & Mosquito production & $\begin{array}{l}\text { Enhanced food security from use of wastewater } \\
\text { in agriculture and aquaculture }\end{array}$ \\
\hline
\end{tabular}

Source: Sustainable Development and Climate Change Department, Asian Development Bank.

${ }^{41}$ WHO. 2016. The Determinants of Health.

${ }^{42}$ M. Birley, M. Gomes, and A. Davy. 1997. Health Aspects of Environmental Assessment. Environ Assess Sourceb. 18. pp. 1-10.

${ }^{43}$ British Medical Association. 1997. Health and Environmental Impact Assessment: An Integrated Approach. Routledge. pp. 274. 


\section{Figure 2: Depiction of Health Outcomes and Health Determinants} as 5-3 Model

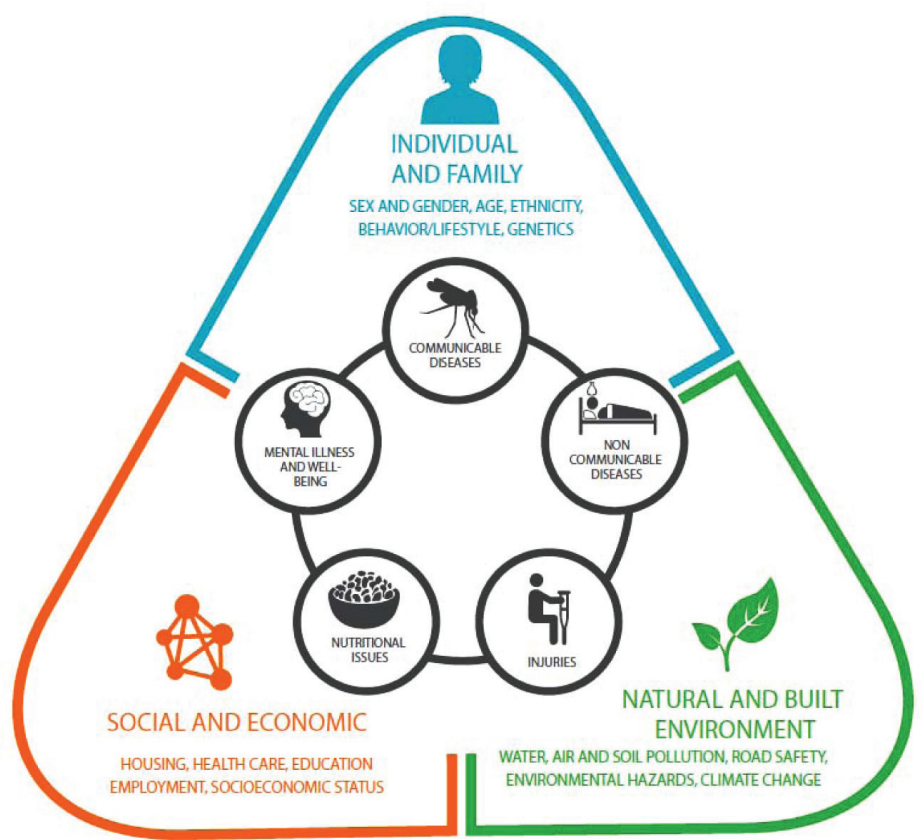

Source: Sustainable Development and Climate Change Department, Asian Development Bank.

Table 8 provides examples of the determinants of health, subdivided by category, that may be encountered in ADB infrastructure projects. Further detail is provided in the subsequent discussion. Infrastructure projects are likely to affect the health determinants associated with the natural and built environment, the social and economic conditions, and individual and family health determinants. There is often a complex relationship between health determinants and this can be captured on a causal diagram. Figure 1 and Figure 3 are examples.

\section{a. Natural and Built Environment Determinants of Health}

53. Some of the natural and built environment determinants of health are included, implicitly, in ADB's existing environmental assessment processes. For example, in the rapid environmental assessment (REA) checklist, there is a question about the transport of hazardous chemicals that could be spilled, by accident, on a road. Spillage of such chemicals could cause acute or chronic poisoning of people and animals. This, in turn, could lead to noncommunicable diseases (such as cancers), injuries (such as acid burns), nutritional disorders (such as malnutrition due to loss of fisheries), and loss of mental well-being (such as stress and anxiety). Some examples of health outcomes associated with changes in the natural and built environment are listed below. Many more examples can be found in WHO publication on preventing disease through healthy environments. ${ }^{44}$

44 J. Peiris et al. 1993. Japanese Encephalitis in Sri Lanka: Comparison of Vector and Virus Ecology in Different Agroclimatic Areas.. Trans R Soc Trop Med Hyg. 87 (5). pp. 541-548. 
Table 8: Health Determinants: Categories, Subcategories, and Examples

\begin{tabular}{|c|c|c|}
\hline $\begin{array}{l}\text { Determinant } \\
\text { Categories }\end{array}$ & Subcategories & Examples That May Be Associated with ADB Projects \\
\hline \multirow[t]{3}{*}{$\begin{array}{l}\text { Natural and built } \\
\text { environment }\end{array}$} & Manufactured & $\begin{array}{l}\text { Quality of air, water, soil, and public realm; traffic, housing, } \\
\text { land use, location; agriculture }\end{array}$ \\
\hline & Natural & $\begin{array}{l}\text { Ecosystems, vectors, disease reservoirs, weather and } \\
\text { climate, water resources, soils, minerals }\end{array}$ \\
\hline & $\begin{array}{l}\text { Physical cultural } \\
\text { resources }\end{array}$ & $\begin{array}{l}\text { Tangible cultural heritage, including movable or immovable } \\
\text { objects, sites, structures, groups of structures, and natural } \\
\text { features and landscapes that have religious or other cultural } \\
\text { significance }\end{array}$ \\
\hline \multirow[t]{5}{*}{$\begin{array}{l}\text { Social and } \\
\text { economic }\end{array}$} & Cohesion & $\begin{array}{l}\text { Community and family structure, culture, crime, gender } \\
\text { inequality, social status, entitlement, severance, involuntary } \\
\text { displacement, migration }\end{array}$ \\
\hline & Economic & $\begin{array}{l}\text { Employment, underemployment, investment, income, debt, } \\
\text { poverty, inequality, access to credit; ownership, wealth; } \\
\text { livelihood }\end{array}$ \\
\hline & Governance & $\begin{array}{l}\text { Policies, regulations, legislation, law, standards and } \\
\text { thresholds; trade rules; corruption and money laundering; } \\
\text { freedom of speech, assembly, and organization; } \\
\text { accountability, transparency, openness, quality assurance; } \\
\text { social and civic participation that ensures accountability } \\
\text { and equity }\end{array}$ \\
\hline & Institutions & $\begin{array}{l}\text { The capacity, capability, and jurisdiction of institutions } \\
\text { to provide accessible services, including medical care, } \\
\text { health promotion, security, transport, government, } \\
\text { education, water supply and sanitation, loans; civil society } \\
\text { organizations }\end{array}$ \\
\hline & Participation & $\begin{array}{l}\text { Freedom of speech, assembly, and organization; social and } \\
\text { civic participation that ensures accountability and equity }\end{array}$ \\
\hline \multirow[t]{3}{*}{$\begin{array}{l}\text { Individual and } \\
\text { family }\end{array}$} & Physiological & $\begin{array}{l}\text { Age, sex, genes, disability, ethnicity, nutritional status, } \\
\text { immunity }\end{array}$ \\
\hline & Behavioral & Attitude to risk, occupation, eating habits \\
\hline & Circumstances & Social status, education, peer pressure \\
\hline
\end{tabular}

Source: Sustainable Development and Climate Change Department, Asian Development Bank.

(i) The introduction of pig-keeping to an upgraded rice irrigation system in Sri Lanka led to an epidemic of Japanese encephalitis (footnote 43).

(ii) The provision of poorly designed domestic water storage jars supplied to households in Viet Nam led to an increase in dengue fever.

(iii) The abundance of accessible and good quality green space in cities is associated with improved mental and physical health.

(iv) Prioritizing motorized private transport has led to an increase in cardiovascular and respiratory diseases associated with breathing polluted air.

(v) Living under the flight path of a major airport is associated with increased cardiovascular disease. 


\section{b. Social and Economic Determinants of Health}

54. The environmental determinants of health are relatively familiar. The social determinants may require more explanation. WHO defines social determinants of health as the conditions in which people are born, grow, live, work and age. ${ }^{45}$ These circumstances are shaped by the distribution of money, power, and resources at global, national, and local levels. The social determinants of health are mostly responsible for health inequities-the unfair and avoidable differences in health status seen within and between countries.

55. The World Health Assembly has requested its member states to act in the following areas to improve the social determinants of health:

(i) Governance - Adopt improved governance for health and development,

(ii) Collaboration - Strengthen global governance and collaboration,

(iii) Participation - Promote participation in policy-making and implementation,

(iv) Promotion - Further reorient the health sector toward promoting health and reducing health inequities, and

(v) Accountability - Monitor progress and increase accountability.

56. The following examples illustrate the diversity and effects of selected social determinants.

(i) Poorly trained and overworked workforces who must work long shifts for low pay may be more vulnerable to infections, injuries, chronic respiratory diseases, and musculoskeletal conditions.

(ii) The social disruption and loss of livelihood associated with becoming a tenant farmer on a rice irrigation system in Sri Lanka led to increased rate of suicide. ${ }^{46}$ The method of choice involved consumption of pesticides provided to control rice pests.

(iii) Building major highways and similar structures through the middle of communities reduces social support networks and increases traffic injuries unless accessible and safe crossing points are provided.

(iv) Childhood malnutrition rates may rise when communities change from subsistence to commercial farming because of unequal entitlements to household income. ${ }^{47}$

(v) For almost all diseases studied, there is a linear relationship between socioeconomic status and health status, referred to as the social gradient. ${ }^{48}$ In more economically equal societies, life expectancy is higher.

(vi) Children in the poorest $20 \%$ of urban households are twice as likely to die as children in the richest $20 \%$ of urban households. ${ }^{49}$

(vii) National reliance on a small number of natural resources, such as minerals, forests, or hydropower can be associated with reductions in life expectancy, increased corruption, and economic underperformance.

(viii) Large construction sites often require large numbers of male workers for long periods of time. When they mix with poor local communities, there is the potential

${ }^{45}$ WHO. What are Social Determinants of Health?

${ }^{46}$ T. Widger. 2014. Suicide in Sri Lanka.

${ }^{47}$ N. Ramachandran. 2006. Women and Food Security in South Asia.

${ }^{48}$ WHO. 2016. Key Concepts.

${ }^{49}$ WHO. 2016. Under-Five Mortality. 
for sexually transmitted infection rates to increase. The health determinants associated with this are often summarized as: mobility, men, money, and mixing.

(ix) Increased costs of food and medical services may make them inaccessible to local communities.

(x) Services that protect health can help to support and buffer communities against adverse health impacts. These services include much more than medical services, public health and environmental health departments. They include police, fire service, water supply, sanitation, energy supply, urban planning and transport. These all have a health protection and health enhancement function. They are also referred to as institutional determinants of health.

\section{c. Individual and Family Determinants of Health}

57. Certain aspects of individual and family determinants of health, such as age, sex, and genetics, cannot be changed by an infrastructure project. The differential effect of malaria on a population exemplifies this fact. In some ecosystems, for example, malaria affects pregnant women and young children more than men. ${ }^{50}$ The project cannot and should not attempt to change the likelihood of pregnancy. In other ecosystems, malaria affects mainly poor men who work in forests and tree plantations independently of the project. There are also genetic variations in susceptibility to disease. For example, Asians are at a higher risk of developing type 2 diabetes compared to people of European ancestry. ${ }^{51}$

\section{Figure 3: Causal Diagram Indicating the Changes in Health Determinants Associated with Health Benefits of the Mandalay Urban Services Improvement Project in Myanmar}

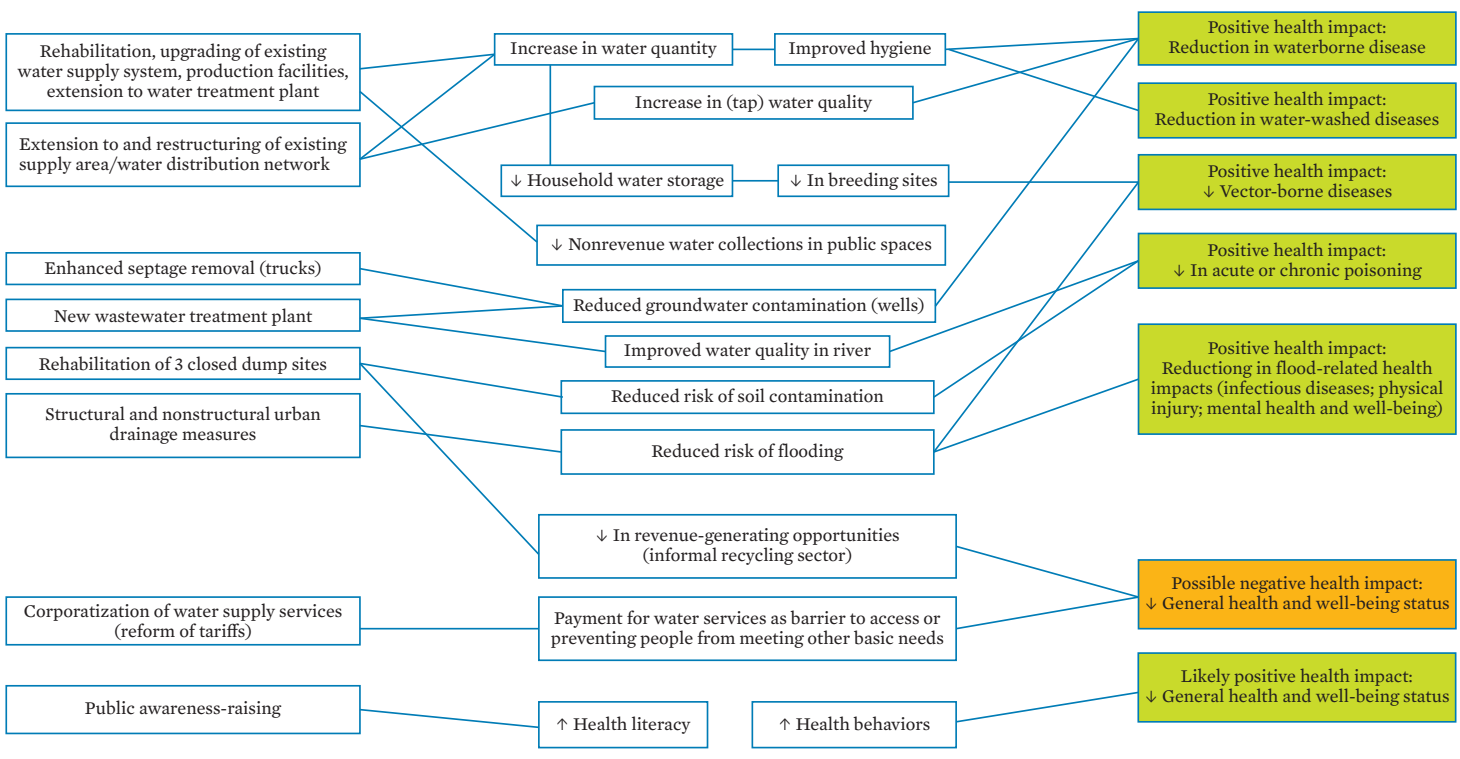

Source: Sustainable Development and Climate Change Department, Asian Development Bank.

${ }^{50}$ WHO. 2017. Malaria in Pregnant Women.

51 J. Chan et al. 2009. Diabetes in Asia: Epidemiology, Risk Factors, and Pathophysiology.. JAMA. 301 (20). pp. 2129-2140. 


\section{Definition of Health Impact Assessment}

\section{Summary}

- Definition of HIA

- Hierarchy of actions required

- The HIA process

- Kinds of HIA

- What HIA is and is not

- Health opportunities, concerns, benefits, and risks in infrastructure development

58. A project's health impact is a direct, indirect, or cumulative change in one or more determinants of health that is attributable to the project. Changes in health determinants produce changes in health outcomes (Figure 4). The changes may be positive or negative, or a mixture of both.

59. WHO and the International Association for Impact Assessment define HIA as a combination of procedures, methods, and tools that systematically judge the potential effects of a policy, plan, program or project, upon the health of a population; and the distribution of those effects within the population. HIA identifies appropriate actions to manage those effects. ${ }^{52}$

60. Distribution of effects refers to the differences in health opportunities and risks that are experienced by different community groups. These can be due to, for example, ethnicity, sex/gender, age, disability, socioeconomic roles and positions, poverty and education, employment, housing, transport, and access to goods and services. The diversity of health inequalities in communities influence the level of vulnerability and, hence, the health impact of a development project.

Figure 4: Changes in Health Determinants

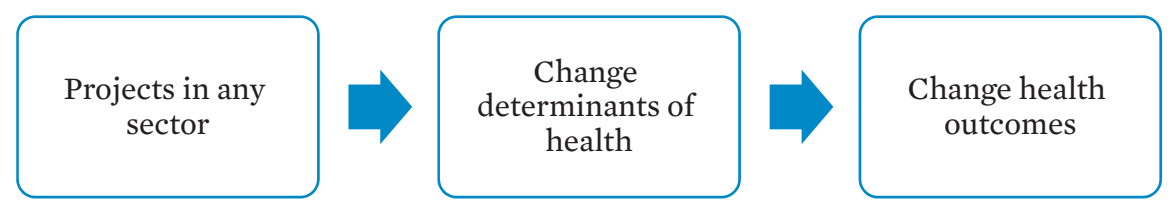

Source: Sustainable Development and Climate Change Department, Asian Development Bank.

\footnotetext{
52 R. Quigley et al. 2006. Health Impact Assessment International Best Practice Principles.
} 
61. The objective of an HIA is to make justifiable recommendations to manage health benefits and risks, as part of the planning, design, and implementation process of a development project. The justification is provided by the analysis of impacts. There is a distinction between projects in which health is a stated objective (water supply and sanitation) and projects where it is not (energy and transport). In the former, the HIA is likely to focus on health enhancement to ensure that the project objectives are met and the health benefits are realized. In the latter, the HIA is likely to focus on the unintended and unstated risks, to ensure that project-related health risks are mitigated.

\section{A. The Health Impact Assessment Process}

62. Figure 5 is a general and ideal view of the entire HIA process. The concepts of procedure and method are separated in the flowchart. The procedure is the management process that enables the technical specialist to use the method. The procedures include deciding whether an HIA is needed, procuring the services of a consultant and appraising their report.

63. The key steps in HIA are similar to EIA and are described below. The main components include:

(i) Screening the project and assigning to a potential impact category.

(ii) Scoping the impact assessment.

(iii) Scheduling the assessment.

(iv) Preparing the project description with components that will impact health during construction and operation

(v) Summarizing applicable legislative, policy, and regulatory frameworks and standards.

(vi) Preparing a baseline report of health conditions in the project location.

(vii) Performing the HIA guided by TOR.

(viii) Preparing the impact assessment report.

(ix) Reviewing and appraising the impact assessment report.

(x) Formulating the PHMP, with a comparison of options and negotiation of resources.

(xi) Implementing the PHMP, with a strong monitoring component.

64. The flowchart includes an option for multiple iterations. This is especially important for bringing healthy design into the engineering design process. Iterations can help ensure that the assessment is sufficiently detailed, but not too detailed. The output of an HIA is a PHMP. The plan includes both enhancement of health benefits and mitigation of health risks.

\section{B. Kinds of Health Impact Assessment}

65. There are many kinds of HIA that are in use but at their core they have the same aim and same broad methodology and process. Some of the distinctions that can be found in the literature and practice are: 
Figure 5: Overview of Health Impact Assessment Procedure and Method

Procedure

Apply screening criteria

(REA and IPSA)

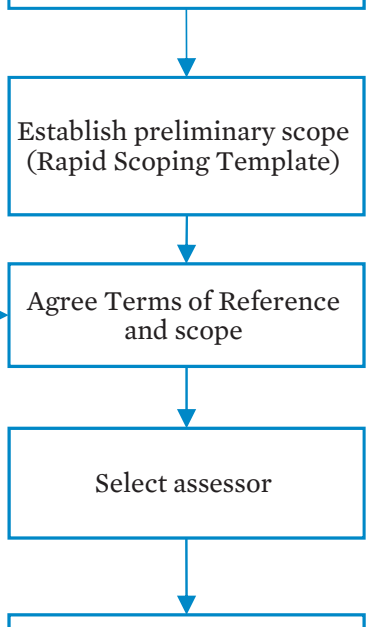

Conduct assessment

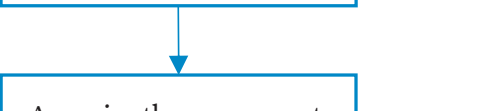

Appraise the assessment report

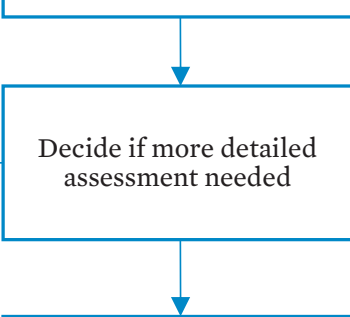

Negotiate favored options (Public Health Management Plan)

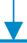

Implement and monitor (Project Performance Monitoring System)

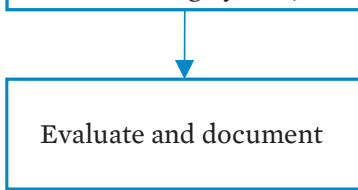

IPSA = initial poverty and social analysis, REA = Rapid Environmental Assessment. Source: Sustainable Development and Climate Change Department, Asian Development Bank.
Collect evidence

Interview stakeholders

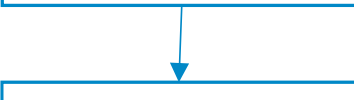

Prepare baseline report

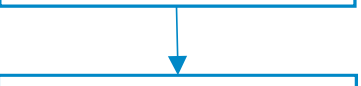

Identify health determinants affected

Assess evidence

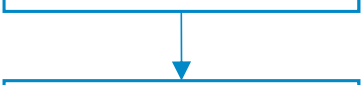

Establish priority impacts

Develop justifiable recommendations

Prepare report

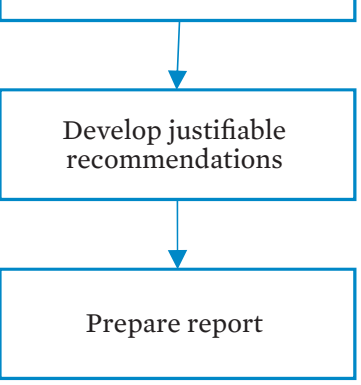


(i) Policy versus project HIA,

(ii) Health within EIA,

(iii) Health within poverty and social analysis (PSA),

(iv) Equity focused HIA,

(v) Healthy spatial planning and healthy urban design,

(vi) Mental well-being impact assessment,

(vii) Rapid, or in-depth HIA, and

(viii) Prospective, concurrent, or retrospective HIA.

66. The focus of this sourcebook is the prospective HIA of infrastructure development projects in the ADB portfolio. The HIA will be coordinated with EIA or PSA; the level of integration of these processes will depend on the nature and magnitude of the project.

\section{What Health Impact Assessment Is and Is Not}

67. HIA is an evidence-based management tool for enhancing potential health gains and mitigating potential health risks during project preparation technical assistance for sovereign loans, or its equivalent in nonsovereign loans. Its use demonstrates to regulatory agencies and communities a client's commitment to improving and protecting CHS.

68. What HIA is not:

(i) Like other impact assessment tools, HIA is not intended to stop projects.

(ii) HIA is not an additional procedure that will slow down loan processing and later implementation. At its simplest, it is an additional chapter and annex in an EIA report.

(iii) It is not a process for channeling development and social investment funds to the health sector to support medical services. It favors public health actions by other sectors involved in the project. Prevention of disease ensures that the health sector is less burdened.

(iv) It is not an academic exercise, a scientific endeavor, an epidemiological study, or a search for absolute truth.

(v) It is not a tool for comparing before-and-after community health conditions.

(vi) It is not limited to quantitative methods.

(vii) It is not only about safeguards, but also about health opportunities.

(viii) It is not a new evaluation procedure.

\section{Opportunities and Concerns}

69. Infrastructure development projects provide a wide range of health opportunities as well as some health concerns. These are registered at the scoping stage and translated by the analytic process into project health benefits and risks. A PHMP is then developed to ensure the benefits and mitigate the risks (Figure 6). 
Figure 6: From Scoping and Analysis to a Public Health Management Plan

Scoping

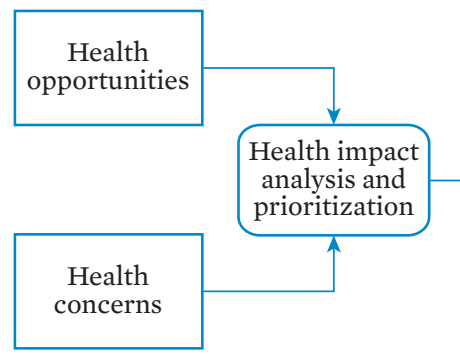

Recommendations

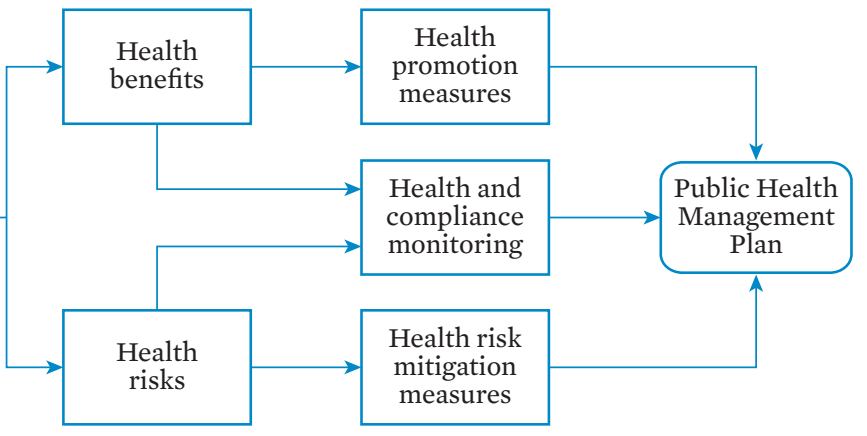

Source: Sustainable Development and Climate Change Department, Asian Development Bank. 


\section{Integration with Bank Procedures}

\section{Summary}

- Comparison of HIA with EIA and PSA

- Adding a health chapter to an EIA report

- Administrative requirements including budget, time, schedule, code of practice

- Competency and procurement of services

70. Impact assessment procedures in ADB are distributed between environmental and social safeguards and poverty reduction specialists-responsible for EIAs, resettlement plans, and indigenous peoples plan; and social development specialists-responsible for PSAs. These procedures consider many, but not all, community health impacts. Impact assessment procedures in $\mathrm{ADB}$ are distributed between environmental and social safeguards and poverty reduction specialists-responsible for EIAs, resettlement plans, and indigenous peoples plan; and social development specialists-responsible for PSAs. These procedures consider many, but not all, community health impacts.

71. ADB uses a balanced approach to managing health issues associated with development projects-it gives similar weight to environmental and social determinants of health. The HIA procedure set out in this sourcebook complements and integrates environmental and social analysis by providing a more detailed CHS analysis (Box 6). Integration ensures that there are no gaps and no overlaps, that resource use is efficient, and that all the project benefits are identified and reported. It also enables mitigation measures to be combined. For example:

(i) An EIA estimates a project's air quality impacts and whether the project may cause national air quality thresholds to be exceeded. The HIA will use the findings of the EIA modelling and assessment to determine whether this may lead to an increase or decrease in cardiovascular and respiratory disease. The HIA will also include recommendations on whether additional mitigation measures are required or not.

\section{Box 6: Air Quality and Health}

Air quality impacts are assessed within environmental impact assessments (EIAs) with a focus on regulatory compliance. This assessment, while often understood as a good proxy indicator of the likely health effects, provides little information on human health risk. The health effects associated with changes in air quality can be better assessed within health impact assessments (HIAs) using the analyses and modelled data from EIA studies. Internal assessment management procedures should be in place to ensure a joint scoping of the EIA and HIA. This will help to ensure that the approach and outputs are defined for the EIA (air quality modelling) and the HIA (health risk assessment) in a complementary way. 
(ii) A PSA estimates whether the differences in income levels (social gradient) between different community groups will be increased or reduced. The HIA will use this finding to assess whether the differences will lead to an increase or decrease in the overall health of the different groups.

72. There are well defined roles and responsibilities in ADB to carry out the environmental assessment and poverty and social analysis of a proposed project, resulting in REA and initial poverty and social analysis (IPSA). It is suggested that, in parallel, health experts in ADB be engaged in these procedures to ensure an evidence-based, integrated, and comprehensive consideration of CHS in EIA and PSA work.

\section{A. Health in Environmental Impact Assessments}

73. In some cases, $\mathrm{ADB}$ may wish to include a health chapter in an EIA or PSA report rather than commission a standalone HIA report. The most common scenario is likely to be an expanded health chapter in an EIA report or adding health inputs in strategic locations within the EIA report. A standalone HIA may be required on a case to case basis..

74. The outputs of many of the other EIA chapters are inputs to the HIA. For example, the air quality chapter estimates the change in outdoor air quality on sensitive receptors as a consequence of the project. A change in outdoor air quality is an environmental determinant of health. Table 9 illustrates the chapter headings that may be used in an EIA of a highways project. Examples are provided of the health determinants that are addressed, implicitly, in each chapter. Five columns indicate the health outcomes that may be affected by changes in the associated health determinants. The health changes may be positive or negative. The table illustrates the diverse range of health determinants and health outcomes that may already be found in other chapters of an EIA report.

75. The objectives of an HIA chapter in an EIA include the following.

(i) To gather the statements relevant to health from all the other EIA chapters and the engineering design documents into one coherent whole that can be read and understood by project officers, other assessment and development specialists, public health officers, and members of the public.

(ii) To identify any health gaps, assess the significance of health impacts, and make justifiable recommendations for managing health impacts.

76. These objectives can be met by the following actions.

(i) Read draft copies of the other chapters and summarize health-related material.

(ii) Identify gaps where health determinants are not assessed in the other chapters and fill those gaps.

(iii) Avoid duplicating material found in other chapters of the EIA and instead cross-reference them extensively.

(iv) Avoid duplicating the recommendations made in other chapters, but instead cross-reference and elucidate as appropriate.

(v) Summarize the significance of health-related impacts found in other chapters, consider the residual impacts and make additional recommendations that reduce the significance to an acceptable level, if necessary. 


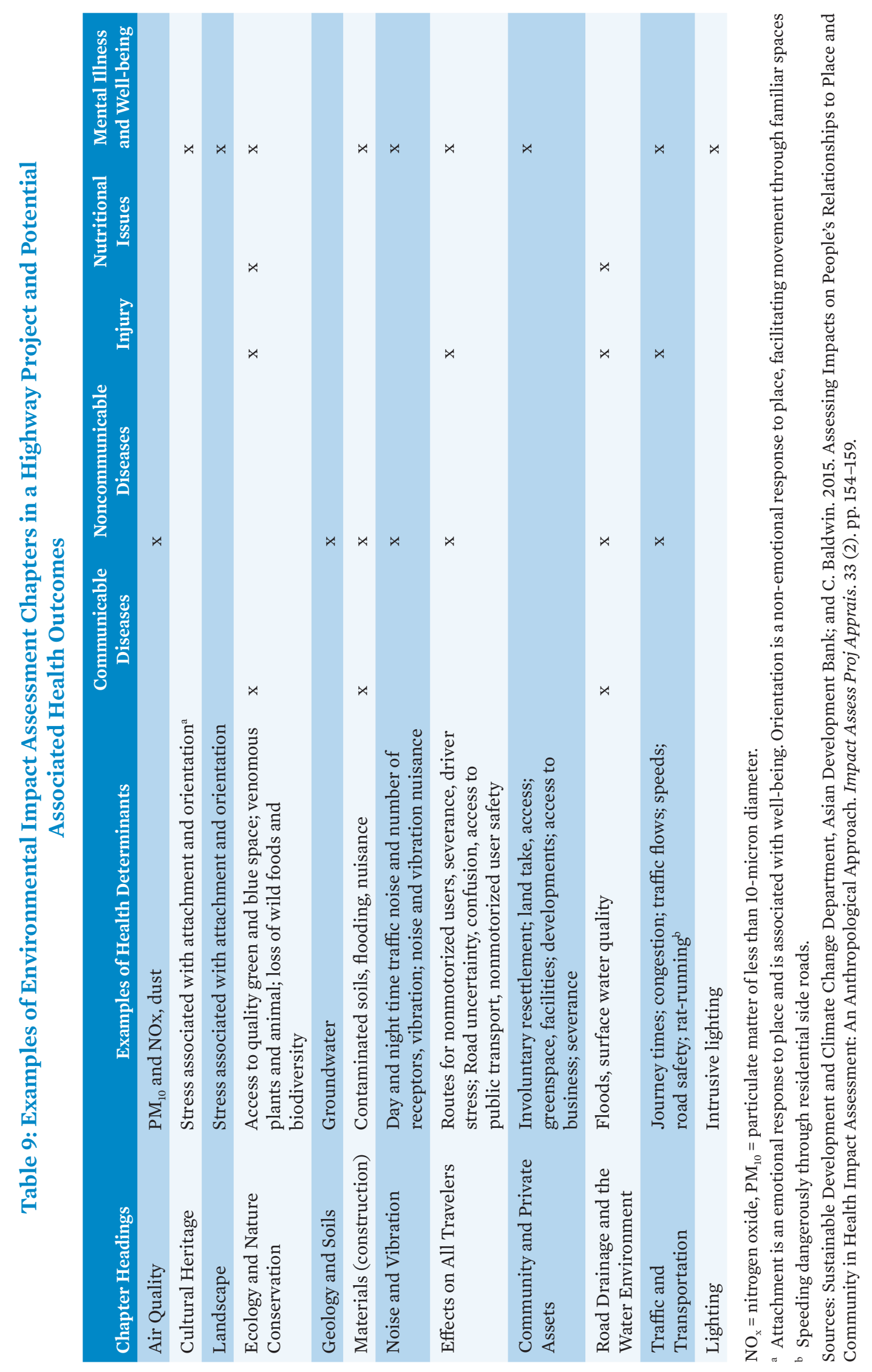




\section{B. Administrative Issues}

77. The financial budget, time available, pool of competent consultants, and quality assurance procedures for undertaking an HIA are limited and require careful management.

\section{Budget}

78. As a rough objective, the budget for an HIA could be $10 \%-20 \%$ of the budget for an EIA. The budget for an EIA is often distributed between many different specialist disciplines, such as air pollution, water pollution, biodiversity, archaeology, and transportation. Community health is generally considered to be one additional specialist discipline that is informed by the findings of many of the other specialist disciplines.

79. The budget is distributed between the different procedural steps required to complete an HIA. One of these is the collection of baseline data. As a rule-of-thumb the baseline work should be limited to well under $50 \%$ of the financial and time budgets available for the whole HIA. This releases time and financial resources for the more important step of developing mitigation and enhancement measures, negotiating and agreeing a PHMP.

80. The implementation of a PHMP requires a separate budget to that used for preparing the HIA or making social investments. This budget is used to deliver several different health enhancement and mitigation measures. Ideally, these measures are limited to managing changes in CHS attributable to the project. They may include some medical care costs. The PHMP budget does not usually include the general cost of strengthening medical services for project-affected communities. In some cases, HIAs are used to negotiate changes in general medical care budgets to meet the increased demand generated by a development project.

\section{Time Budget and Schedule}

81. The time requirement of an HIA is fitted to the budget available. Two levels of assessment are often distinguished, as indicated in Table 10. There is no international definition of these levels, or the resources required. An in-depth assessment is likely to require 10 times the resources of a rapid assessment.

82. The screening and scoping stages that take place before the assessment proper can be regarded as brief, high-level assessments in themselves. The quality of the assessment is more important than the time taken. An experienced HIA consultant may be able to identify the key issues and justify recommendations relatively quickly.

83. The outputs of the EIA and other assessments are often inputs to the HIA. This can affect timing. The HIA may start at the same time as the environmental and social assessments, but cannot be completed until the findings of the other reports are available, at least in draft.

Table 10: Resources Required for Two Levels of Assessment

$\begin{aligned} & \text { Level of Assessment } \\ & \text { Rapid }\end{aligned}$
$\begin{array}{ll}\text { In-depth } & \text { Desk exercise, brief field visit, consult key informants, published health data } \\ \text { Several specialist staff, social surveys, sampling of health determinants }\end{array}$
Source: Sustainable Development and Climate Change Department, Asian Development Bank.


On the other hand, much of the information needed may be collected and analyzed by the other specialists, saving time and money and preventing duplication.

\section{Code of Practice}

84. All impact assessments require interpretation and judgment and these should be guided by a professional code of ethics. HIA is no different. A simple code, applicable to all forms of impact assessment has been issued by the International Association for Impact Assessment. ${ }^{53}$ Typical principles include: community participation in decision making, equity, sustainable development, ethical use of evidence, respect for human rights, avoidance of bias, and distributive and procedural justice. ${ }^{54}$ It is difficult to ensure and demonstrate that an HIA is unbiased, credible, and robust. Ideally, the consultants writing the report are seen to act independently of $\mathrm{ADB}$ and the project owner.

\section{Competency Frameworks}

85. There is a relative shortage of competent HIA practitioners. More curriculum development and training courses are needed. Different levels of competency are required for overseeing an HIA process, carrying out a technical HIA, reviewing a draft report, running training courses, and advancing the subject. At the time of writing, there are no international standards or certification schemes. ADB has an opportunity to promote competency through its technical assistance and through its oversight of development loans, by assisting DMCs in establishing HIA competency frameworks, university curricula (Box 7), and performance standards, and by ensuring that the procurement of consultancy services meets acceptable standards.

86. HIA requires two kinds of competencies. The first kind is competency of government officers whose responsibility is to regulate HIA. The second kind is for managers and consultants who are HIA practitioners. Managers procure the services of consultants and oversee their work. Consultants undertake HIAs of specific projects. Standards are needed to ensure the quality of consultants' services.

87. A competent assessment team includes someone who has training and experience in HIA, together with graduate or postgraduate education in a health-related discipline such as public health or epidemiology. The team may also require an experienced HIA practitioner who is knowledgeable about the potential health impacts of similar development projects. Such consultants may not necessarily be familiar with the country or region. The team will also require national consultants who have public health, environmental health, or epidemiology education and who speak the local language, even if such consultants are not experienced in HIA. It is often advisable to include a 1-week training or refresher course on HIA for the team, the government and ADB staff, as part of the kick-off process. The training course could be included in the TOR. This can help ensure that stakeholders have the same understanding of and share the same expectations of the HIA. It also helps with team building.

88. Table 11 presents four different levels of basic competency for HIA and indicates some of their uses [adapted from ${ }^{5}$ ]. The lead HIA consultant should have competency level 3 or 4

${ }^{53}$ IAIA. 2016. Ethical Responsibilities.

${ }^{54}$ M. Birley. 2011. Health Impact Assessment, Principles and Practice.

${ }^{55}$ S. Vohra and M. Birley. Health Impact Assessment: Summary of the Good Practice Guidance. The International Council on Mining and Metals. 


\section{Box 7: Curriculum Development in Greater Mekong Subregion Universities}

The Asian Development Bank (ADB) has recognized the need of strengthening health impact assessment (HIA) capacity across the Greater Mekong Subregion (GMS). A strategic approach to capacity building was to increase the skills and knowledge of those currently involved in HIA as well as building a new generation of HIA experts.

To ensure long-term advancement and sustainability of HIA in the GMS, ADB worked with GMS public health institutions to expand HIA teaching through curriculum development and research in the region. ADB commissioned the Curtin University (Western Australia) which is a World Health Organization Collaborating Centre for Environmental Health Impact Assessment to develop and conduct HIA curriculum and teaching courses at the regional and country levels in different public health and environmental science faculties of universities across the GMS. The curriculum for each of the various settings were developed: (i) HIA in environmental impact assessment; (ii) HIA in public health, environment and planning courses; and (iii) Standalone HIA, and delivered accordingly by the following GMS universities:

(i) University of Health Sciences (Lao People's Democratic Republic)

(ii) University of Public Health - Yangon (Myanmar)

(iii) Mahidol University (Thailand)

(iv) Hanoi Medical University (Viet Nam)

(v) Ho Chi Minh University of Medicine and Pharmacy (Viet Nam)

(vi) Hue University of Medicine and Pharmacy (Viet Nam)

Source: Sustainable Development and Climate Change Department, Asian Development Bank.

and the team members (if any) should have competency level 2 or 3. If the HIA is integrated with other assessments, such as EIA, there will be an overall team leader with at least level 1 competence. Government counterparts should also have level 1 competence.

Table 11: Competency Framework for Health Impact Assessment Practitioners

\begin{tabular}{|c|c|c|}
\hline Levels & How Obtained & Some Uses \\
\hline 1 Awareness & $\begin{array}{l}\text { Attends one-day introductory health } \\
\text { impact assessment (HIA) course }\end{array}$ & $\begin{array}{l}\text { - Know what needs to be managed } \\
\text { - Can regulate and negotiate } \\
\text { - Can screen projects }\end{array}$ \\
\hline 2 Knowledge & Attends five-day HIA course & $\begin{array}{l}\text { - Can contribute to an HIA as a team member } \\
\text { - Can liaise with members of the social and } \\
\text { environmental teams } \\
\text { - Can explain and advocate HIA to project } \\
\text { managers, communities and other stakeholders } \\
\text { - Can commission HIAs }\end{array}$ \\
\hline 3 Skilled & $\begin{array}{l}\text { 2-years' experience of doing HIA; } \\
\text { Has attended both courses; } \\
\text { Public or environmental health, or } \\
\text { similar, to master's degree level }\end{array}$ & $\begin{array}{l}\text { - Can lead an HIA and manage the HIA process } \\
\text { - Can appraise and audit an HIA }\end{array}$ \\
\hline 4 Expert & $\begin{array}{l}\text { Substantial experience of HIA; } \\
\text { National or international reputation; } \\
\text { Professional qualification in public } \\
\text { health or equivalent; } \\
\text { Familiar with state-of-the-art; } \\
\text { 5-years' experience of doing HIA }\end{array}$ & $\begin{array}{l}\text { - Can improve HIA methods and procedures } \\
\text { - Can adapt HIA to new situations } \\
\text { - Can provide back-up expertise } \\
\text { - Can provide authoritative advice to } \\
\text { governments, multinational corporations and } \\
\text { multilateral organizations } \\
\text { - Can teach HIA at postgraduate level }\end{array}$ \\
\hline
\end{tabular}

Source: Sustainable Development and Climate Change Department, Asian Development Bank. 


\section{Screening and Classification}

\section{Summary}

- Addition of screening questions to existing rapid impact assessment and initial poverty and social analysis checklists

- Projects with and without explicit health objectives

- Optional classification system to determine the level of health assessment

- Urban development example

\section{A. Screening}

89. The output of screening is to assign a project to a specific impact class, and a decision on whether an HIA is needed or not. ADB screens projects for impact through the REA and IPSA checklists. Many of the questions in these two checklist systems address the determinants of health implicitly or explicitly (Figure 7).

\section{Additions to REA and IPSA}

90. Given this, a separate CHS or HIA checklist has not been developed. Instead, a small number of additional CHS questions and footnotes have been added to the existing checklists (Tables 12 and 13).

91. The IPSA checklist has not been changed, but a new footnote should be added, framed as similar footnotes in the checklist:

Obligation is recognized in enhancing the health benefits and reducing the health risks associated with an infrastructure project through changes in both the social and environmental determinants of health. 


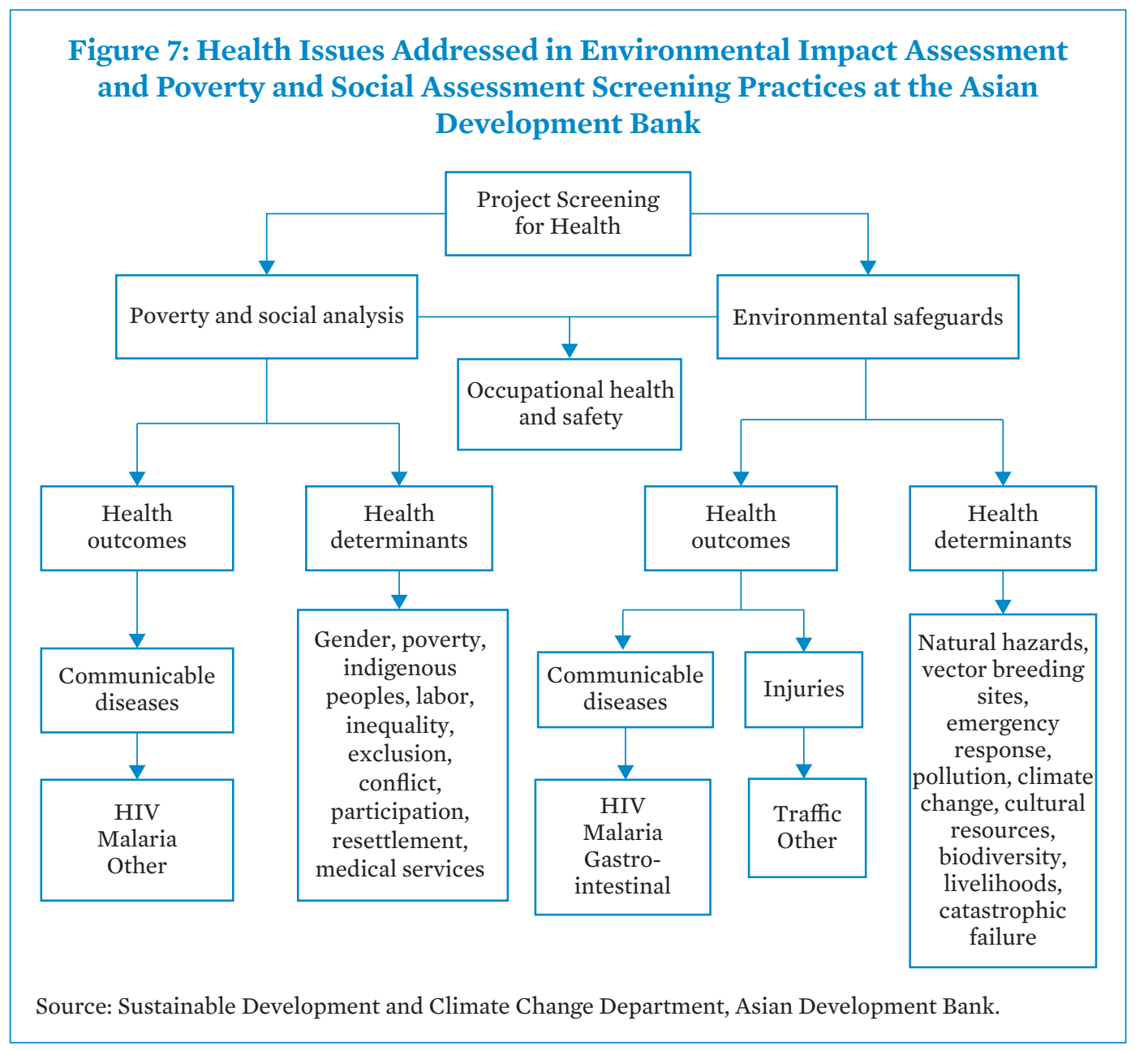

Table 12: Additions to Rapid Impact Assessment Questions on Project Siting

$\quad$ Is the Project Sited in a Locality With
All projects
A malaria or zoonotic disease hotspot? ${ }^{\text {a }}$
A high water table? ${ }^{b}$
Important fisheries?
Tourist potential?
Dense human habitation?

a Forests, forest edges, tree plantations, and coastal shrimp farms are the main malaria habitats in the Greater Mekong Subregion. See also the Appendix "Communicable diseases including vector-borne diseases in infrastructure development."

b Wastewater disposal practices can cause pooling, especially in areas with high water tables. Pooling of wastewater can promote mosquito vectors of filariasis.

Source: Sustainable Development and Climate Change Department, Asian Development Bank. 
Table 13: Additions to Sector-Specific Rapid Environmental Assessment Questions

\begin{tabular}{|c|c|}
\hline Sector/Theme & Will the Project Cause \\
\hline $\begin{array}{l}\text { Roads and } \\
\text { highways }\end{array}$ & $\begin{array}{l}\text { - Community severance? }{ }^{a} \\
\text { - Long-distance trucking? } \\
\text { - Reduced access to public services? } \\
\text { - Reduction in active travel? } \\
\text { Transboundary movement or migration of people or animals? }\end{array}$ \\
\hline Water supply & $\begin{array}{l}\text { - Increase in domestic or industrial container water storage? } \\
\text { - Increase in mineral content of drinking water? } \\
\text { - Increase in service interruptions because of under-design? }\end{array}$ \\
\hline Sewage & $\begin{array}{l}\text { - Interference with other utilities and blocking of access to buildings? } \\
\text { - Health risks and nuisance to neighboring community's due to noise, smell, and an Increase in the } \\
\text { population density of insects (vectors) and rodents (disease reservoirs)? } \\
\text { - Substantial increases in unsafe use of wastewater or fecal sludge? }\end{array}$ \\
\hline $\begin{array}{l}\text { Urban } \\
\text { development }\end{array}$ & $\begin{array}{l}\text { - A reduction in access to good quality green and blue space, attractive public realms, public services or } \\
\text { community centers? } \\
\text { - A reduction in housing mix and affordability? } \\
\text { - A reduction in access to raw fresh foods and food markets? } \\
\text { - An increase in domestic, industrial, or construction site water storage? } \\
\text { - An increase in pit latrines or surface drains? } \\
\text { - Exclusion of waste pickers and urban farmers? } \\
\text { - An increase in private car transportation? } \\
\text { - A modal shift from safe active transport options? } \\
\text { - Increased commuting times? } \\
\text { - An increase in the density of human settlements? } \\
\text { - An increase in nighttime noise during operation? } \\
\text { - An increase in indoor or outdoor temperature extremes (e.g., through poor insulation or loss of shade)? } \\
\text { - A net increase in national carbon dioxide emissions? }\end{array}$ \\
\hline Hydropower & $\begin{array}{l}\text { - An increase in road traffic injuries on access roads? } \\
\text { - A reduction in nutritional status due to loss of a staple food or disruption of irrigated or downstream } \\
\text { recession agriculture? } \\
\text { - Increase in vector breeding or human contact with vectors? } \\
\text { - Loss of clean drinking water supplies? } \\
\text { - A localized boom and bust economic effect? } \\
\text { - Modified downstream hydrology leading to increased irrigated agriculture with consequences for } \\
\text { human health (disease vector breeding, intensified pesticide use, nutritional status) }\end{array}$ \\
\hline $\begin{array}{l}\text { Wind and solar } \\
\text { power }\end{array}$ & - Anxiety about flicker, glare, or electromagnetic radiation? \\
\hline $\begin{array}{l}\text { Power supply in } \\
\text { general }\end{array}$ & $\begin{array}{l}\text { - A reduction in accountable, transparent, predictable and affordable energy supplies? } \\
\text { - An increase in carbon dioxide emissions? }\end{array}$ \\
\hline $\begin{array}{l}\text { Power } \\
\text { transmission }\end{array}$ & $\begin{array}{l}\text { - Perception of risk from electromagnetic radiation? } \\
\text { - Risks to human health from storage and use of herbicides?e }\end{array}$ \\
\hline $\begin{array}{l}\text { Construction in } \\
\text { general }\end{array}$ & $\begin{array}{l}\text { - Price inflation of local goods and services? } \\
\text { - Increased risks of community injury? } \\
\text { - Increased risk of exposure to pollution? } \\
\text { - Increased risk of sexually transmitted infections? }\end{array}$ \\
\hline
\end{tabular}

a Severance - separating a previously integrated community by a physical barrier such as a highway. This is associated with loss of social support networks. It can be mitigated by providing bridges, underpasses and crossings.

b Storage of water in containers in the home or on industrial sites can promote the mosquito vector of dengue, dengue hemorrhagic fever, Chikungunya, and Zika virus.

c Mineral content deficits and exceedances are associated with a range of human diseases. For example, excessive arsenic or insufficient iodine can cause chronic diseases as has occurred in Bangladesh. In parts of the Mekong River arsenic is also present in groundwater. Excessive fluoride concentrations lead to bone diseases. At the right doses, calcium and magnesium will help protect against cardiovascular diseases.

${ }^{d}$ Consideration may be required of the safe use of wastewater following the World Health Organization guidelines. The half-life of parasites in fecal sludge varies from a few days to 6 months.

e Herbicides are used to clear the vegetation along the transmission line.

Source: Sustainable Development and Climate Change Department, Asian Development Bank. 
Table 14: Suggested Screening Questions for Health Infrastructure Projects

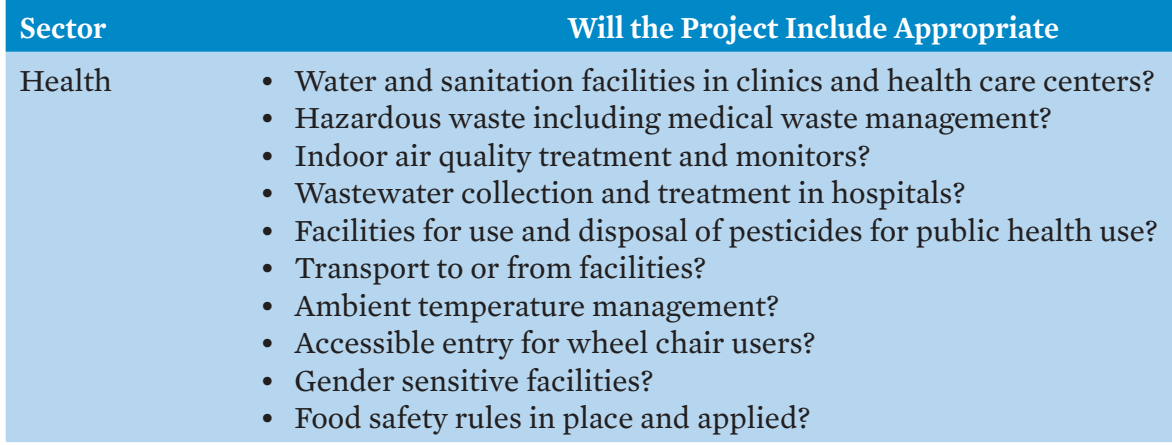

Source: Sustainable Development and Climate Change Department, Asian Development Bank.

\section{Health Sector Projects}

92. Health infrastructure projects and health services delivery plans and programs are not exempt from screening for health impacts (Table 14).

\section{Mixed Health Opportunities and Risks}

93. Infrastructure projects contain a mixture of health opportunities and health risks. For example:

(i) A highway project may improve access to health service facilities but increase the incidence of road traffic injuries

(ii) Cyclists in cities are exposed to the risk of road traffic injury and air pollution. On the other hand, active travel promotes both physical and mental health. Studies indicate that the health benefits are about ten times greater than the health risks. Bike transport projects are therefore likely to be classed as beneficial for health in most cities. ${ }^{56}$

94. In addition, some projects have explicit health objectives (Table 15). These projects may require a HIA to ensure that the associated health determinants are fully identified and indicators are established that enable achievements to be measured.

\section{Health Screening at the Construction Stage of Any Project}

95. Construction can impact human health through land take, heavy vehicle movement, migrant and local workforces, population influx, involuntary resettlement, labor camps, pollution of air, water and soil, movement of hazardous chemicals, noise and vibration, light pollution, encroachment on sacred sites, landscape alteration, temporary severance and route diversion, encroachment of the public onto construction site, and catastrophic failure of infrastructure. Many of these are already captured in the REA and IPSA.

${ }^{56}$ M. Tainio et al. 2016. Can Air Pollution Negate the Health Benefits of Cycling and Walking? Prev Med. 87. pp. 233-236. 
Table 15: Projects with Explicit Health Objectives

\begin{tabular}{|c|c|c|}
\hline Sector & $\begin{array}{c}\text { Does the Project Usually } \\
\text { Include Explicit Health } \\
\text { Objectives? }\end{array}$ & Example of Objectives \\
\hline Water supply & Yes & Improving access to safe drinking water \\
\hline Sanitation & Yes & Reducing health risks related to poor sanitation \\
\hline Sewage & Yes & Improving disposal of hazardous waste \\
\hline Roads and highways & No & Reducing transport times \\
\hline Urban development & No & Increasing sustainability \\
\hline Energy & No & Increasing domestic and industrial energy supplies \\
\hline Agriculture & Yes or no & $\begin{array}{l}\text { Improving food security and promoting healthy, } \\
\text { balanced diets }\end{array}$ \\
\hline
\end{tabular}

Source: Sustainable Development and Climate Change Department, Asian Development Bank.

96. Construction workers are also exposed to various risks brought about by construction activities. The US Occupational Safety and Health Administration has identified the "Fatal Four" in the construction industry. These are falls, struck by object, electrocution, and caught-in-between (including crushing injuries) ${ }^{57}$ These hazards along with other hazards that may be present should be covered by the impacts analysis and occupational health and safety (OHS) risk assessments.

97. Construction projects often seek to maximize local procurement of goods and services such as hire of a local trucking firm. This brings positive economic and health benefits to the community. Other health consideration during construction include the following.

(i) Dense concentrations of workers around large construction projects can promote the use of alcohol, narcotics, and commercial sex.

(ii) Migrant workforces may bring communicable diseases such as malaria, tuberculosis, and HIV. They should be screened and treated on arrival. It is illegal in most countries to discriminate against workers on medical grounds.

(iii) Construction sites and their access roads are often noisy and polluted. Dust emissions, heavy trucks, and ground vibrations can be a major source of nuisance to peripheral communities.

(iv) Construction sites can encroach on and damage sites of special spiritual or cultural importance, causing anger and distress. They may also encroach on public recreation lands, and common land used for animal grazing.

(v) Large construction projects often include onsite doctors and nurses with well-planned stabilization and evacuation procedures. By contrast, local clinics may be poorly staffed and resourced. A protocol may be required that enables the two to call on each other's services in emergencies.

${ }^{57}$ Occupational Safety and Health Administration. Commonly Used Statistics. 
Figure 8: Output of Screening for Health Concerns

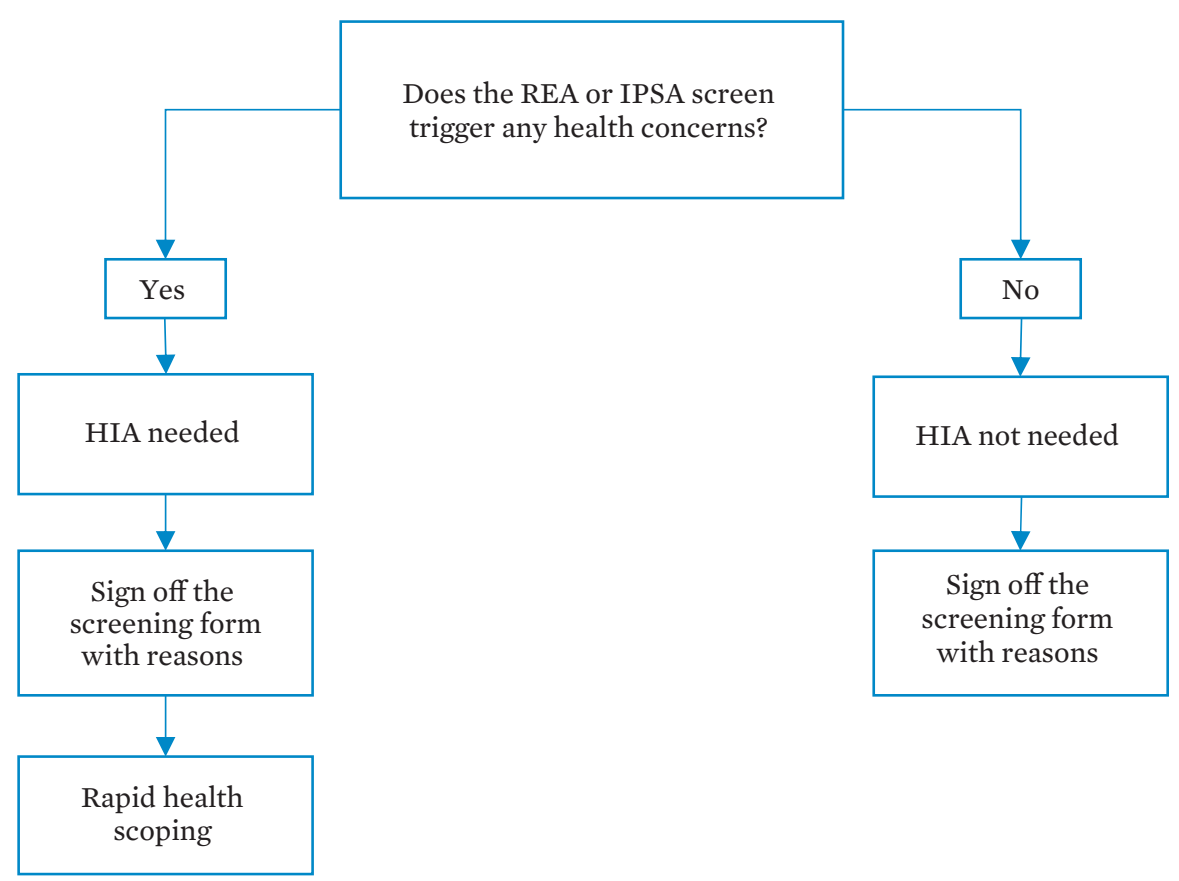

HIA = health impact assessment, IPSA = initial poverty and social analysis, REA = rapid environmental assessment.

Source: Sustainable Development and Climate Change Department, Asian Development Bank.

\section{Output of Screening}

98. The rapid screening process leads to a conclusion that the project does or does not trigger any health concerns (Figure 8). If there are health concerns, further assessment takes place, starting with a rapid health scoping described below.

\section{B. Examples of Screening Urban Development Projects for Health}

\section{Introduction}

99. ADB has set out its vision to transform the archetypal chaotic, polluted, inequitable cities of Asia into economically competitive, ${ }^{58}$ equitable, and environmentally sustainable urban regions ${ }^{59}$-or livable cities. ${ }^{60}$ This supports SDG 11. A livable city is green, ${ }^{61}$ safe,

\footnotetext{
58 ADB. 2013. Urban Operational Plan 2012-2020. Asian Development Bank. Manila.

${ }^{59}$ ADB. 2015. ADB's Vision of Livable Cities. Manila.

${ }^{60}$ S. Sandhu. 2016. GrEEEn Solutions for Livable Cities. Manila: ADB.

${ }^{61}$ ADB. 2012. Green Cities. Manila.
} 
sustainable, and healthy. At the heart of the envisioned transformation of Asia's cities is a new integrated planning approach to the provision of infrastructure and services and other public goods. This new approach to integrated urban planning has three interrelated dimensions (called the 3Es): economic competitiveness, environmental sustainability or green growth, equity or social inclusiveness. Cities are the engines of economic growth and have lifted millions out of poverty. But rapid urban growth creates many challenges. These lead to reductions in quality of life, well-being, livability, and population health. They are mediated by depletion of natural resources, rising demand for urban services, increasing household consumption, increasing vulnerability to natural hazards and risks from climate change, and increasing levels of pollution and greenhouse gas emissions. Many of these are closely linked to health determinants. The same factors that promote green, livable cities, also promote, well-being, quality of life, and human health.

100. Health is not mentioned explicitly in the ADB urban vision or plans, except in terms of the provision of medical care. Yet many of the proposed actions address the determinants of health and have the potential to bring substantial health benefits to urban communities. An explicit approach to addressing health issues will help to ensure that health benefits are maximized and health risks are minimized. The following tables provide examples of the health outcomes and health determinants associated with urban development.

\section{Table 16: Examples of Positive and Negative Health Outcomes Associated with Urbanization and Urban Projects}

\begin{tabular}{lll}
$\begin{array}{l}\text { Categories of } \\
\text { Health Outcomes }\end{array}$ & \multicolumn{1}{c}{ Positive Impacts } & \multicolumn{1}{c}{ Negative Impacts } \\
$\begin{array}{l}\text { Communicable } \\
\text { diseases }\end{array}$ & $\begin{array}{l}\text { Reduction in exposure to many } \\
\text { rural diseases, such as malaria }\end{array}$ & $\begin{array}{l}\text { Dengue fever, the mosquito is associated } \\
\text { with small collections of clean water }\end{array}$ \\
\hline $\begin{array}{l}\text { Noncommunicable } \\
\text { diseases }\end{array}$ & $\begin{array}{l}\text { Improving lung status associated } \\
\text { with reduced indoor air pollution }\end{array}$ & $\begin{array}{l}\text { Respiratory diseases associated with } \\
\text { inhalation of fine particulates }\end{array}$ \\
\hline Injury & $\begin{array}{l}\text { Reduction in domestic burns } \\
\text { associated with safer cooking stoves }\end{array}$ & $\begin{array}{l}\text { Road traffic injuries associated with } \\
\text { busy traffic }\end{array}$ \\
\hline Nutrition & $\begin{array}{l}\text { Improved nutrition associated with } \\
\text { new economic opportunities }\end{array}$ & $\begin{array}{l}\text { Obesity associated with fast foods and } \\
\text { highly refined ingredients }\end{array}$ \\
\hline $\begin{array}{l}\text { Mental illness and } \\
\text { well-being }\end{array}$ & $\begin{array}{l}\text { Well-being associated with having } \\
\text { supportive neighborhoods }\end{array}$ & $\begin{array}{l}\text { Stress and anxiety associated with fear } \\
\text { of violence }\end{array}$ \\
\hline
\end{tabular}

Source: Sustainable Development and Climate Change Department, Asian Development Bank.

\section{Table 17: Examples of the Environmental and Social Determinants of Health That May Be Affected by Urban Projects}

\begin{tabular}{ll} 
Category of Health Determinant & \multicolumn{1}{c}{ Examples Associated with Urban Development } \\
Environmental & - Public transport \\
& - Clean drinking water in taps \\
& - Heavy goods vehicles on congested roads \\
Social & - Equitable access to public services \\
& - Improved livelihoods \\
& - Economic inequality
\end{tabular}

Source: Sustainable Development and Climate Change Department, Asian Development Bank. 


\section{Co-Benefits}

101. ADB promotes a co-benefits approach: initiatives for solving challenges in one sector can solve challenges in many sectors (footnote 60). For example, reducing greenhouse gas (GHG) emissions improves energy security, livability, income generation, wealth distribution, and air quality.

102. ADB has framed this as interconnecting the 3Es. There is a fourth benefit: public health and well-being. Maximizing the co-benefits depends on an assessment of the direct and indirect impacts of each initiative. Examples of co-benefits follow:

(i) Reducing GHG emissions from urban transport provides health co-benefits through reducing particulate emissions and enhancing active travel.

(ii) Improving urban green space can provide recreational opportunities, enhance social ties, offer educational opportunities, bolster regional identity and competitiveness, boost tourism performance, as well as promoting physical and mental health.

\section{Urban Climate Change Resilience}

103. Climate change is a public health emergency. Table 18 provides examples of the urban health outcomes of climate change. These outcomes are the consequence of changes in a range of health determinants. These include a risk of increasing social inequality as many impacts affect the poor first.

104. Urban climate change resilience includes adaptation, mitigation, disaster risk reduction, and response to uncertainty. ${ }^{62}$ Resilience planning requires engagement with multiple stakeholders in an iterative, inclusive, and integrated process. This should include public and environmental health officers as well as the health care system. Health care systems are generally under-resourced and overstretched. They are likely to lack the infrastructure to resist flooding, provide emergency power, or regulate the temperature in health centers.

Table 18: Examples of the Urban Health Outcomes of Climate Change

\begin{tabular}{|ll|}
\hline Category & \multicolumn{1}{c|}{ Example } \\
\hline Communicable diseases & $\begin{array}{l}\text { Increased risks of waterborne diseases such as cholera } \\
\text { Increased risks of vector-borne diseases such as malaria, filariasis, } \\
\text { and plague }\end{array}$ \\
\hline Noncommunicable diseases & $\begin{array}{l}\text { Respiratory diseases associated with reduced air quality including } \\
\text { allergens }\end{array}$ \\
\hline Injury & $\begin{array}{l}\text { Drowning } \\
\text { Communal violence and looting }\end{array}$ \\
Heat stress
\end{tabular}

Source: Sustainable Development and Climate Change Department, Asian Development Bank.

${ }^{62}$ ADB. 2014. Urban Climate Change Resilience: A Synopsis. Manila. 


\section{Spatial Planning and Health}

105. The strong links between spatial planning and health are often overlooked. Spatial planning is said to have had its origins in public health. There are many ongoing initiatives that strengthen the linkage. These include, for example, WHO Healthy Cities Program (footnote 25 and 26) ${ }^{63}$, now broadened to Healthy Settings, and the London Healthy Urban Development Unit. ${ }^{64}$ These focus on the many positive impacts that urban planning can have on human health, well-being, and quality of life. As an example, Table 19 is a summary of the London Healthy Urban Development Unit checklist. It identifies four key themes and then connects these to planning on the one hand, and health and wellbeing on the other hand.

106. The key themes are likely to vary between cities. For example, in Cambodia the environmental and social health determinants of establishing garment industries in the city centers include poor working and living conditions, air and water pollution, and heavy traffic.

Table 19: Healthy Urban Design Unit Checklist for Urban Planning

\begin{tabular}{|c|c|c|}
\hline Theme & Planning Issue & Health and Well-being Issue \\
\hline 1. Health housing & $\begin{array}{l}\text { - Housing design } \\
\text { - Accessible housing } \\
\text { - Healthy living } \\
\text { - Housing mix and } \\
\text { affordability }\end{array}$ & $\begin{array}{l}\text { - Lack of living space - overcrowding } \\
\text { - Unhealthy living environment - daylight, } \\
\text { ventilation, noise } \\
\text { - Excess deaths due to cold/overheating } \\
\text { - Injuries in the home } \\
\text { - Mental illness from social isolation and fear of } \\
\text { crime }\end{array}$ \\
\hline 2. Active travel & $\begin{array}{l}\text { - Promoting walking and } \\
\text { cycling } \\
\text { - Safety } \\
\text { - Connectivity } \\
\text { - Minimising car use }\end{array}$ & $\begin{array}{l}\text { - Physical inactivity, cardiovascular disease and } \\
\text { obesity } \\
\text { - Road and traffic injuries } \\
\text { - Mental illness from social isolation } \\
\text { - Noise and air pollution from traffic }\end{array}$ \\
\hline $\begin{array}{l}\text { 3. Healthy } \\
\text { environment }\end{array}$ & $\begin{array}{l}\text { - Construction } \\
\text { - } \text { Air quality } \\
\text { - } \text { Noise } \\
\text { - } \text { Opontaminated land } \\
\text { - Play space } \\
\text { - Biodiversity } \\
\text { - Local food growing } \\
\text { - Flood risk } \\
\text { - Overheating }\end{array}$ & $\begin{array}{l}\text { - Disturbance and stress caused by construction } \\
\text { activity } \\
\text { - Poor air quality - lung and heart disease } \\
\text { - Disturbance from noisy activities and uses } \\
\text { - Health risks from toxicity of contaminated land } \\
\text { - Physical inactivity, cardiovascular disease and } \\
\text { obesity } \\
\text { - Mental health benefits from access to nature and } \\
\text { green space and water } \\
\text { - Opportunities for food growing - active lifestyles, } \\
\text { - healthy diet and tackling food poverty } \\
\text { Excess summer deaths due to overheating }\end{array}$ \\
\hline $\begin{array}{l}\text { 4. Vibrant } \\
\text { neighbourhoods }\end{array}$ & $\begin{array}{l}\text { - Healthcare services } \\
\text { - Education } \\
\text { - Access to social } \\
\text { infrastructure } \\
\text { - Local employment and } \\
\text { healthy workplaces } \\
\text { - Access to local food shops } \\
\text { - Public buildings and } \\
\text { spaces }\end{array}$ & $\begin{array}{l}\text { - Access to services and health inequalities } \\
\text { - Mental illness and poor self-esteem associated } \\
\text { with unemployment and poverty } \\
\text { - Limited access to healthy food linked to obesity } \\
\text { and related diseases } \\
\text { - Poor environment leading to physical inactivity } \\
\text { - Ill health exacerbated through isolation, lack of } \\
\text { social contact and fear of crime }\end{array}$ \\
\hline
\end{tabular}

Source: Healthy Urban Development Unit. 2015. Healthy Urban Planning Checklist, second edition.

${ }^{63}$ H. Barton and C. Tsourou. 2000. Healthy Urban Planning.

${ }^{64}$ Healthy Urban Development Unit. 2014. Rapid Health Impact Assessment Tool, second edition. 


\section{Urban Diseases and Infrastructure Development}

107. A wide range of diseases in the urban and peri-urban areas have environmental and social determinants. The prevalence rate is often distributed unequally across socioeconomic groups. The most vulnerable communities are usually in the peri-urban fringe, in informal settlements with low incomes. They are exposed to a combination of both rural and urban health determinants. ${ }^{65}$

108. Urbanization is often associated with a sedentary lifestyle that affects physical and mental health. One of the keys to health urban projects is the promotion of active travel: walking, cycling, and using public transport. In addition to providing exercise, air quality is improved through a reduction in private motorized transport. Lack of physical activity accounts for $31 \%$ of ischemic heart disease, $30 \%$ of breast cancers, $27 \%$ of colon and rectum cancers, and $9 \%$ of stroke. Exercise is also a cost-efficient treatment for mild to moderate depression. The following tables illustrate some of the associations between urban development and human health.

\section{Table 20: Examples of Urban Communicable Diseases}

\begin{tabular}{|c|c|c|}
\hline Class & Health Outcome & Determinant \\
\hline \multirow[t]{3}{*}{ Vector-borne } & Filariasis & $\begin{array}{l}\text { The common urban mosquito that transmits filariasis breeds } \\
\text { in organically polluted water such as septic tanks, pit latrines, } \\
\text { open ditches, wastewater pools, and sewage ponds. It bites at } \\
\text { night and rests indoors. }\end{array}$ \\
\hline & Dengue fever & $\begin{array}{l}\text { By contrast, the mosquito that transmits dengue fever has } \\
\text { very different habits. It breeds in temporary collections of } \\
\text { clean water. These include flower vases, ant traps, drip trays, } \\
\text { domestic water storage jars, hollow pipes, as well as discarded } \\
\text { car tires, tins, bottles, and plastic cups. The eggs remain } \\
\text { viable when water dries up and hatch when the container is } \\
\text { reflooded. They bite outdoors during the day }\end{array}$ \\
\hline & Malaria & $\begin{array}{l}\text { The malaria mosquitoes in Southeast Asia are usually not } \\
\text { found in urban areas because of the pollution. They can be } \\
\text { found in parks and peri-urban areas associated with clean } \\
\text { water, crops, and trees or forests. } \\
\text { In some parts of Asia, malaria vectors breed in domestic } \\
\text { overhead water tanks and other outdoor water containers. }\end{array}$ \\
\hline Fecal-oral & $\begin{array}{l}\text { Various viruses, } \\
\text { parasites, and } \\
\text { worms }\end{array}$ & $\begin{array}{l}\text { Many pathogens are associated with human feces. Clean } \\
\text { drinking water can be contaminated with feces if pipe pressure } \\
\text { drops or it is stored in open containers. } \\
\text { - Sewage is a valued commodity used to grow salads and other } \\
\text { food crops in peri-urban areas. Pathogens contaminate the } \\
\text { food crops. } \\
\text { - Dried sludge from sewage treatment plants is a valuable } \\
\text { fertilizer but may contain parasites if it is not stored for long } \\
\text { enough. }\end{array}$ \\
\hline
\end{tabular}

Source: Sustainable Development and Climate Change Department, Asian Development Bank.

${ }^{65}$ M. Birley and K. Lock. 1999. The Health Impacts of Peri-urban Natural Resource Development. Liverpool School of Tropical Medicine. 
Table 21: Examples of Urban Noncommunicable Diseases

\begin{tabular}{|c|c|c|}
\hline Class & Health Outcome & Determinant \\
\hline $\begin{array}{l}\text { Sedentary } \\
\text { life-styles }\end{array}$ & $\begin{array}{l}\text { Hypertension, heart } \\
\text { attacks, strokes, } \\
\text { obesity }\end{array}$ & $\begin{array}{l}\text { Many urban dwellers have sedentary occupations. A } \\
\text { minimum level of daily physical activity is required to } \\
\text { maintain health. This can be obtained from active travel } \\
\text { including walking, cycling, or use of public transport. } \\
\text { Recreational exercise is also helpful. Physical activity is } \\
\text { promoted by a safe and attractive public realm, including } \\
\text { access to parks and open spaces. Public buildings } \\
\text { could prioritize stairs over elevators, as in the Asian } \\
\text { Development Bank. }\end{array}$ \\
\hline Air quality & $\begin{array}{l}\text { Wide range of heart } \\
\text { and lung diseases }\end{array}$ & $\begin{array}{l}\text { - There is no lower safe limit to concentrations of key air } \\
\text { pollutants: no point at which harmful health impacts cease. } \\
\text { - Both indoor and outdoor, or ambient, air pollution are } \\
\text { important. } \\
\text { - Traffic, industry and domestic fuel are key sources of } \\
\text { ambient air pollution } \\
\text { - Second-hand tobacco smoke and domestic fuel are key } \\
\text { sources of indoor air pollution }\end{array}$ \\
\hline
\end{tabular}

Source: Sustainable Development and Climate Change Department, Asian Development Bank.

Table 22: Other Urban Health Issues

\begin{tabular}{|c|c|c|}
\hline Class & Health Outcome & Determinant \\
\hline Injuries & $\begin{array}{l}\text { Trauma, drowning, } \\
\text { heat stress }\end{array}$ & $\begin{array}{l}\text { - Road traffic injuries affect pedestrians and cyclists as much } \\
\text { as vehicle occupants } \\
\text { - Drowning is associated with flooding, many cities are at risk } \\
\text { - Temperature extremes affect the health of the most } \\
\text { vulnerable including the very young and old }\end{array}$ \\
\hline Severance & $\begin{array}{l}\text { Injuries, mental } \\
\text { health and } \\
\text { well-being }\end{array}$ & $\begin{array}{l}\text { - Causes people to dodge traffic and risk injury } \\
\text { - Causes loss of social cohesion and social support, and is } \\
\text { associated with mental illness } \\
\text { - Reduces access to public services such as medical care }\end{array}$ \\
\hline Noise & $\begin{array}{l}\text { Mental illness and } \\
\text { well-being }\end{array}$ & $\begin{array}{l}\text { Urban noise levels can impede sleep, disrupt education, } \\
\text { change behavior and reduce mental and spiritual well-being }\end{array}$ \\
\hline Nutrition & Obesity and diabetes & $\begin{array}{l}\text { Migration to cities is associated with dietary changes from } \\
\text { diverse sources with higher roughage content toward } \\
\text { refined sugars, flours, and processed meats. This leads to } \\
\text { overweight, obesity, diabetes, and many other diseases } \\
\text { - Sale of high fat, high sugar, high sodium fast foods is often } \\
\text { of importance near schools }\end{array}$ \\
\hline
\end{tabular}

Source: Sustainable Development and Climate Change Department, Asian Development Bank. 
Table 23: Other Components of the Urban Environment That Are Critical for Health

\begin{tabular}{ll} 
Determinant & \multicolumn{1}{c}{ Health Outcomes } \\
\hline Housing and shelter & $\begin{array}{l}\text { Lack of appropriate housing is associated with stress, anxiety, } \\
\text { and depression, acute and chronic ill-health such as bronchitis, } \\
\text { asthma, pneumonia, tuberculosis, delayed cognitive development, } \\
\text { and physical injury }\end{array}$ \\
\hline Water supply and sanitation & - Dengue, gastrointestinal infections, filariasis \\
\hline Energy & - Heart and lung diseases \\
\hline Transport & - Physical fitness, heart and lung diseases, mental health
\end{tabular}

Source: Sustainable Development and Climate Change Department, Asian Development Bank.

\section{Peri-Urban Areas}

109. Peri-urban areas are vital to cities. They produce much of the food consumed and receive much of the waste products from the city. They also tend to contain associated industries such as abattoirs and tanneries. They are often poorly provided with services such as clean water supplies and proper wastewater disposal systems. They attract the migrating poor from rural areas who live in informal settlements made out of waste materials. Key cottage industries include scavenging and recycling waste. This can include dismantling lead acid batteries to retrieve the lead. Salad crops are often grown in untreated or partially treated sewage and become coated with parasites such as Ascaris, which can survive many months. When these are carried to the kitchen and consumed, the cycle of infection is repeated.

110. Those who acquire jobs in the formal sector often commute large distances at higher relative costs of time and money. Public transport systems in the peri-urban fringe are often unlicensed, poorly maintained, overcrowded, polluting, and unsafe. Food may be prepared and sold by informal street vendors using unsafe practices that produce injuries such as burns and scalds. Hygiene standards may be low and contamination with pathogens high. The need for a long working hours and long commutes reduces the time available for domestic activities. Food may be prepared in the home and stored for long periods, increasing the risk of contamination. The types of food prepared by new migrants may change toward higher fat and starch and less nutrients. Such foods have shorter preparation times and longer storage lives.

111. The peri-urban area can be a meeting point between the diseases common in the countryside and the diseases common in the city. It can have the worst of both worlds. Livestock raising and aquaculture are part of the peri-urban scene. This can introduce a range of zoonoses. For example, a study in Ho Chi Minh City in the 1990s, identified some 20 significant zoonotic diseases associated with slaughterhouses. The use of excreta and organic waste in aquaculture is associated with a range of communicable diseases. Transmission is avoided when the fish are well-cleaned and cooked. Consumption of raw or partially cooked fish from ponds poses the greatest risk. Noncommunicable diseases include poisoning from the many chemicals used in aquaculture or from natural toxins produced by algae. 


\section{Health Screening for the Operational Stage of Urban Projects}

112. Table 24 lists key health questions that should be asked about the planned operational stage of an urban project. There are many kinds of urban development projects and the key questions may not apply to all of them.

Table 24: Key Health Questions for Urban Projects, Operational Stage

\begin{tabular}{ll} 
Category & \multicolumn{1}{c}{ Question } \\
Air quality & - Will ambient or indoor air quality deteriorate or be improved? \\
& - Are there sufficient air quality monitoring sites? \\
\hline Active travel & - Will the project encourage modal shift toward active travel? \\
& - Will public buildings promote stairs rather than elevators? \\
- Will affordable public transport be available always?
\end{tabular}

Source: Sustainable Development and Climate Change Department, Asian Development Bank.

\section{Health Classification}

113. The REA and IPSA screening tools enable a project to be classified to determine the level of impact assessment that is required. Table 25 indicates how the existing classification system can be used to judge the significance of a change in CHS and hence the level of health impact assessment that is required. The most severe health impacts are life-threatening, irreversible, or substantially incapacitating, and difficult to treat. They create an additional burden for the health sector and may undermine the sustainability of the project. The classification is not mandatory but aims to be a guidepost for ADB staff. 
Table 25: Health Classification

\begin{tabular}{|c|c|c|}
\hline Class & Summary & Action Required \\
\hline \multirow[t]{3}{*}{ A } & $\begin{array}{l}\text { The project is expected to change the risk of one or more health } \\
\text { outcomes, and some of these are life-threatening, irreversible, } \\
\text { substantially incapacitating, or difficult to treat. Mitigation will } \\
\text { require careful analysis. }\end{array}$ & \multirow[t]{3}{*}{$\begin{array}{l}\text { HIA and public } \\
\text { health management } \\
\text { plan }\end{array}$} \\
\hline & $\begin{array}{l}\text { The project is expected to provide significant improvements } \\
\text { to CHS (or has health objectives) and additional assessment is } \\
\text { required to understand the pathways, indicators and optimal } \\
\text { enhancement measures. }\end{array}$ & \\
\hline & HIA will add significant improvements to the project & \\
\hline \multirow[t]{3}{*}{ B } & $\begin{array}{l}\text { There is uncertainty about the severity and likelihood of changes } \\
\text { in health attributable to the project. }\end{array}$ & \multirow{3}{*}{$\begin{array}{l}\text { Rapid HIA, possibly } \\
\text { leading to some } \\
\text { additional health } \\
\text { measures }\end{array}$} \\
\hline & $\begin{array}{l}\text { The project is expected to provide improvements to CHS (or has } \\
\text { health objectives) and some additional assessment is required to } \\
\text { understand the pathways, indicators and optimal enhancement } \\
\text { measures. }\end{array}$ & \\
\hline & A rapid HIA is required. & \\
\hline \multirow[t]{3}{*}{$\mathrm{C}$} & $\begin{array}{l}\text { The project is expected to change the risk of one or more } \\
\text { health outcomes, but these are usually not life-threatening, or } \\
\text { are of short duration, or are easily treatable, and can easily be } \\
\text { mitigated. }\end{array}$ & \multirow[t]{3}{*}{$\begin{array}{l}\text { Monitoring plan } \\
\text { with preparedness } \\
\text { of project and } \\
\text { community health } \\
\text { services }\end{array}$} \\
\hline & $\begin{array}{l}\text { The project is expected to provide improvements to CHS and no } \\
\text { additional assessment is required to understand the pathways, } \\
\text { indicators and optimal enhancement measures. }\end{array}$ & \\
\hline & HIA will not add significant improvements to the project & \\
\hline FI & $\begin{array}{l}\text { Funds to a financial intermediary that must apply and maintain } \\
\text { their own environmental and social management system }\end{array}$ & $\begin{array}{l}\text { Environmental and } \\
\text { social management } \\
\text { systems used } \\
\text { by the financial } \\
\text { intermediary }\end{array}$ \\
\hline
\end{tabular}

CHS = community health and safety, HIA = Health Impact Assessment.

Source: Sustainable Development and Climate Change Department, Asian Development Bank. 


\section{Scoping}

\section{Summary}

- The purpose of scoping

- The rapid scoping template

- At the scoping stage, there is an initial list of health opportunities and concerns; these are translated by the HIA into a final list of health benefits and risks

- A generic list of health concerns is provided for each key sector

- The communities affected by the project, considered by gender, age, sex, poverty, and inequality

- Poverty, inequality, and health

- Considering occupational health and safety but assessed separately from community health and safety

- Scoping the geographic and temporal boundaries

114. The scoping process identifies which health opportunities and concerns, communities, project phases, and locations should be included in the HIA. The output of scoping is a preliminary list of these to include in the TOR for the HIA (Appendix 3).

115. The scope is based on the operational definition of community health and safety defined in this sourcebook. This enables a broad range of health issues to be identified and addressed. Otherwise, the assessment will be limited to the risks usually considered under the REAs and IPSAs, such as air pollution, dust and noise, accidents, and injuries and a few communicable diseases.

116. A rapid scoping template (RST) is then completed and this provides the basis for the TOR for the health consultant, who should be instructed to refine and tailor the scope to the specific project. The RST is included in Appendix 2. The key contents of the RST template are as follows.

(i) Basic data about the project;

(ii) Project overview;

(iii) Project objectives;

(iv) Geographical and temporal scope of assessment;

(v) Community scope of assessment, including gender, age, indigenous people, resettlement, migration, other stakeholders;

(vi) Health impacts initial scope of health priorities (opportunities and concerns), including communicable diseases, noncommunicable diseases, nutritional issues, injuries, mental health, and well-being;

(vii) Health determinants that may be affected (opportunities and concerns), including physical and social environment; 
(viii) Health impacts that can be addressed in the project through design, other mitigation, health improvement, medical service provision, and commissioned research;

(ix) Initial scope of work for HIA consultant(s), as TOR for scoping report;

(x) Acceptance of scoping report;

(xi) Next steps, including drafting TOR for HIA consultant(s).

\section{A. Opportunities and Concerns}

117. Scoping takes place at the early stages of a health assessment when little information and analysis is available. It includes a list of perceived health opportunities and health concerns associated with the project. These are translated by the analytic process into health benefits and risks.

\section{Health Opportunities}

118. The scope identifies the health opportunities in the project for improving community health and safety. For example, a new road can provide remote villages with access to health services in addition to providing construction companies with access to project sites. The analysis step of the HIA assesses these opportunities, prioritizes them, and presents them as the health benefits of the project. A decision is then made with regard to the health benefits that can realistically be included in the project design, construction, and operation (Box 8).

\section{Health Concerns}

119. In addition to considering health opportunities, the scope identifies health concerns (Box 9). For example, a new road may create breeding sites for malaria mosquitoes in drainage ditches. It may increase the risk of road traffic accidents, if there is insufficient

\section{Box 8: A Health Impact Assessment of a Very Large Sewer Project in England}

The project required major underground construction throughout the length of a city. Three similar large construction sites were needed on the surface, located in the west, the center, and the east. Very detailed baseline data was available for the city population. This indicated that there were major geographical differences in community health status. The average healthy life expectancy of people in the western part was 13 years longer than people living in the eastern part. Although the construction sites were similar, the impact on the communities near the sites was likely to be different. The key positive health impacts were reduced flood risk through improved surface water drainage, improved domestic wastewater management, and creation of some new public spaces. The key negative impacts were related to the construction phase and included local disruption, noise, odor, increase in heavy goods vehicle traffic, and some loss of existing parks and public spaces. The health impact assessment identified some additional mitigation measures that were not in the environmental impact assessment. These influenced both the design of the sewer and the environmental management plans for the construction phase. 
attention to the needs of nonmotorized users or traffic calming. In urban settings, roads may reduce active travel modes, reducing physical activity, and increasing the risk of obesity and a range of noncommunicable diseases. Roads may also increase outdoor air pollution and the associated risk of diseases. Increased mobility and new movements of people may introduce communicable diseases into communities where they were not prevalent before. Road construction workers are exposed to high risk of heat stroke, musculoskeletal disorder, and other injuries. As with opportunities, the assessment can then prioritize the concerns and present them as health risks that can realistically be mitigated through the project design, construction, and operation.

\section{Box 9: Health Impact Assessment of a Flood Action Plan in Bangladesh}

The project planned to build embankments on major rivers to control annual river floods. The health impact assessment (HIA) identified three major health concerns.

(i) Would the change in water management lead to a change in malaria, kala-azar and other vector-borne diseases? The baseline study established that the risk of local malaria transmission was low. The main reason for this appeared to be that potential breeding sites were too polluted. The risk of increased transmission was rated as low.

(ii) Would the change in flood regime affect access to food? Many of the urban poor relied on river flooding to catch fish to supplement their diet. Agricultural land was in limited supply, but when fields were flooded everyone had the right to fish on them. The HIA concluded that there was a high risk that reduction in flooding would increase the risk of malnutrition by removing the opportunity for poor communities to catch fish. The HIA recommended that flood control measures should include some annual flooding, rather than seeking to eliminate it completely.

(iii) One of the objectives of flood control was to protect shallow wells used for drinking water. The alternative solution was to provide deep tube wells. The water from these deep wells was protected from pathogens, but contaminated with arsenic salts that caused widespread poisoning. No HIA was conducted on the strategy for deep boreholes. Had an HIA been conducted, the risk of arsenic poisoning might have been identified although it was a relatively unknown issue at that time. Clearly, substituting one ill-health outcome (diarrheal diseases) with another (skin disease, cancer) is not a desirable result of a development project.

a Visceral leishmaniasis, a potentially lethal vector-borne disease.

Source: Sustainable Development and Climate Change Department, Asian Development Bank.

\section{B. Priority Health Concerns by Sector}

120. The following tables indicate some of the health issues that should be included in the scope of a HIA, by key sectors (Box 10 and Box 11). For further information see the ADB publication A Primer on Health Impacts of Development Programs (footnote 30). A balanced approach to setting the scope pf health concerns is recommended. Balance can be improved by including all five health outcome categories. The specialist consultant, responsible for the HIA, should be instructed to modify the initial scope to fit the requirements of a specific project, in consultation with stakeholders. The list of health concerns is necessarily incomplete. It is sufficient for the TOR of the health consultant, who is expected to refine the list to finalize the scope. 
Table 26: Water and Sanitation

\begin{tabular}{|c|c|c|}
\hline $\begin{array}{l}\text { Health Outcome } \\
\text { Category }\end{array}$ & Health Concern & Context \\
\hline \multirow[t]{6}{*}{$\begin{array}{l}\text { Communicable } \\
\text { diseases }\end{array}$} & Malaria & $\begin{array}{l}\text { The mosquito vector breeds in shallow, clean water. } \\
\text { Focal distribution associated with specific ecosystems. } \\
\text { In South Asia, it can be urban or rural, elsewhere it is } \\
\text { rural. In Southeast Asia, it is associated with forests and } \\
\text { coasts. Can be associated with small rural drinking supply } \\
\text { systems and with irrigation systems. }\end{array}$ \\
\hline & $\begin{array}{l}\text { Dengue, Zika, } \\
\text { Chikungunya, and } \\
\text { other arboviruses }\end{array}$ & $\begin{array}{l}\text { One important mosquito breeds in containers of clean } \\
\text { water. Wide distribution, largely urban. Severe epidemics. } \\
\text { Association with domestic drinking water storage. }\end{array}$ \\
\hline & $\begin{array}{l}\text { Lymphatic } \\
\text { filariasis }\end{array}$ & $\begin{array}{l}\text { Most common form associated with urban and peri-urban } \\
\text { areas, where the mosquito vector breeds in organically } \\
\text { polluted water. Strong association with poor sanitation. }\end{array}$ \\
\hline & Skin diseases & $\begin{array}{l}\text { Some are associated with lack of domestic water for } \\
\text { hygiene }\end{array}$ \\
\hline & $\begin{array}{l}\text { Diarrhea } \\
\text { and other } \\
\text { gastrointestinal } \\
\text { infections }\end{array}$ & $\begin{array}{l}\text { Clean and abundant drinking water supplies and } \\
\text { improved hygiene reduce risk. Food contamination } \\
\text { reduced by washing. Many pathogens associated with } \\
\text { sewage. Safe use of wastewater is encouraged and there } \\
\text { are WHO guidelines. Association with flooding and } \\
\text { drought, intermittent piped water supply systems, poor } \\
\text { latrines and open defecation. }\end{array}$ \\
\hline & $\begin{array}{l}\text { STIs, HIV and } \\
\text { AIDS }\end{array}$ & $\begin{array}{l}\text { Large construction sites with migrant labor and/or camp } \\
\text { followers or poor peripheral communities and gender } \\
\text { inequality }\end{array}$ \\
\hline \multirow[t]{3}{*}{$\begin{array}{l}\text { Noncommunicable } \\
\text { diseases }\end{array}$} & Poisoning, various & $\begin{array}{l}\text { Chronic contamination of drinking water with excess } \\
\text { concentrations of poisonous minerals such as arsenic, } \\
\text { fluoride, lead, and nitrites occurring naturally or through } \\
\text { industrial and agricultural waste. }\end{array}$ \\
\hline & $\begin{array}{l}\text { Respiratory } \\
\text { diseases }\end{array}$ & $\begin{array}{l}\text { The practice of boiling water stored at home may lead } \\
\text { to increased indoor air pollution and result in increased } \\
\text { respiratory disease }\end{array}$ \\
\hline & $\begin{array}{l}\text { Cardiovascular } \\
\text { disease }\end{array}$ & $\begin{array}{l}\text { Poor mineral content }(\mathrm{Mg}++) \text { of drinking water from } \\
\text { certain sources. }\end{array}$ \\
\hline Nutritional issues & Under-nutrition & $\begin{array}{l}\text { A significant side effect of water- and/or sanitation- } \\
\text { related diarrheal diseases }\end{array}$ \\
\hline \multirow[t]{3}{*}{ Injuries } & Drowning & $\begin{array}{l}\text { An issue linked to deep-sided reservoirs that are } \\
\text { accessible to local communities. }\end{array}$ \\
\hline & Falls and crushing & $\begin{array}{l}\text { Inadequate safety systems on construction sites and poor } \\
\text { construction traffic management. }\end{array}$ \\
\hline & Explosion & $\begin{array}{l}\text { Methane build-up in water supply and sewage treatment } \\
\text { plants }\end{array}$ \\
\hline \multirow[t]{2}{*}{$\begin{array}{l}\text { Mental health and } \\
\text { well-being }\end{array}$} & Well-being & $\begin{array}{l}\text { Improvements associated with secure water supplies and } \\
\text { improved latrines. }\end{array}$ \\
\hline & $\begin{array}{l}\text { Stress, anxiety, } \\
\text { depression }\end{array}$ & $\begin{array}{l}\text { Often associated with the disruption and change resulting } \\
\text { from construction or resettlement }\end{array}$ \\
\hline
\end{tabular}

STIs = sexually transmitted infections.

Source: Sustainable Development and Climate Change Department, Asian Development Bank. 
Table 27: Energy

\begin{tabular}{|c|c|c|}
\hline $\begin{array}{l}\text { Health Outcome } \\
\text { Category }\end{array}$ & Health Concern & Context \\
\hline \multirow[t]{5}{*}{$\begin{array}{l}\text { Communicable } \\
\text { diseases }\end{array}$} & Malaria & $\begin{array}{l}\text { The mosquito vector breeds in shallow, clean water. } \\
\text { Focal distribution associated with specific ecosystems. } \\
\text { In South Asia, it can be urban or rural, elsewhere } \\
\text { it is rural. In Southeast Asia, it is associated with } \\
\text { forests and coasts. Not generally associated with } \\
\text { reservoirs themselves, but with the ecosystems in } \\
\text { which reservoirs and resettlement sites are located. } \\
\text { For example: rockpools in rivers downstream of dams, } \\
\text { created by changed hydrology. Climate change will } \\
\text { increase the range. }\end{array}$ \\
\hline & $\begin{array}{l}\text { Dengue, Zika, } \\
\text { Chikungunya, and } \\
\text { other arboviruses }\end{array}$ & $\begin{array}{l}\text { One important mosquito breeds in containers of } \\
\text { clean water. Wide distribution, largely urban. Severe } \\
\text { epidemics. Association with air conditioning systems } \\
\text { such as drip trays. Climate change will increase the } \\
\text { range. }\end{array}$ \\
\hline & $\begin{array}{l}\text { Acute and chronic } \\
\text { respiratory } \\
\text { infections }\end{array}$ & $\begin{array}{l}\text { Air pollution associated with the products of } \\
\text { combustion of fossil fuels or biomass. Association with } \\
\text { urban outdoor air pollution. } \\
\text { Association with indoor combustion of biomass. }\end{array}$ \\
\hline & STIs & $\begin{array}{l}\text { Large construction sites with migrant labor and/or } \\
\text { camp followers or poor peripheral communities and } \\
\text { gender inequality }\end{array}$ \\
\hline & $\begin{array}{l}\text { Opisthorchiasis, } \\
\text { Paragonomiasis }\end{array}$ & Reservoirs, fishing, eating raw fish \\
\hline \multirow[t]{4}{*}{$\begin{array}{l}\text { Noncommunicable } \\
\text { diseases }\end{array}$} & Poisoning, various & $\begin{array}{l}\text { Fly ash disposal, heavy metals from geothermal plants, } \\
\text { disposal of photovoltaic panels. }\end{array}$ \\
\hline & $\begin{array}{l}\text { Respiratory } \\
\text { diseases such as } \\
\text { bronchitis, asthma }\end{array}$ & $\begin{array}{l}\text { Air pollution with the products of combustion of fossil } \\
\text { fuels or biomass. Association with urban outdoor air } \\
\text { pollution. } \\
\text { Association with indoor combustion of biomass. }\end{array}$ \\
\hline & Cancers & $\begin{array}{l}\text { Air pollution with the products of combustion of fossil } \\
\text { fuels or biomass. Association with urban outdoor air } \\
\text { pollution. }\end{array}$ \\
\hline & & $\begin{array}{l}\text { Association with indoor combustion of biomass. } \\
\text { Association with hazardous materials such as } \\
\text { polychlorinated biphenyls. }\end{array}$ \\
\hline Nutritional issues & Undernutrition & $\begin{array}{l}\text { Loss of livelihoods from resettlement and from climate } \\
\text { change }\end{array}$ \\
\hline \multirow[t]{3}{*}{ Injuries } & Drowning & $\begin{array}{l}\text { Deep-sided reservoirs, floods. Extreme weather } \\
\text { conditions associated with climate change }\end{array}$ \\
\hline & Falls and crushing & $\begin{array}{l}\text { Inadequate safety systems on construction sites. Poor } \\
\text { construction traffic management. }\end{array}$ \\
\hline & Explosion & Transport and storage of fossil fuels \\
\hline \multirow[t]{2}{*}{$\begin{array}{l}\text { Mental health and } \\
\text { well-being }\end{array}$} & Well-being & $\begin{array}{l}\text { Improvements associated with electric lights, fans, } \\
\text { airconditioning, refrigeration }\end{array}$ \\
\hline & $\begin{array}{l}\text { Stress, anxiety, } \\
\text { depression }\end{array}$ & $\begin{array}{l}\text { Disruption and change associated with construction } \\
\text { or resettlement. Provision of inappropriate energy } \\
\text { sources. }\end{array}$ \\
\hline
\end{tabular}

STIs = sexually transmitted infections.

Source: Sustainable Development and Climate Change Department, Asian Development Bank. 


\section{Box 10: Nam Theun 2 Hydropower Project in the Lao People's Democratic Republic}

The Nam Theun 2 Hydropower project is located in Khammouane province, in central Lao People's Democratic Republic. Before the start of the project, a rapid health impact assessment (HIA) was conducted that focuses more on the construction activity and the early commissioning and operation phases. The HIA distinguished the Project into discrete "potential impact areas of concern" that include not only the immediate construction but also the surrounding communities. They were as follows:

(i) Villages in the Nam Theun 2 watershed,

(ii) Plateau resettlement area,

(iii) Nam Theun riparian and watershed area,

(iv) Construction work camps,

(v) Camp followers: family,

(vi) Camp followers: service,

(vii) Villages along the Nam Kathang and the upper Xe Bang Fai,

(viii) Villages along the middle and lower Xe Bang Fai,

(ix) Transmission line corridor, and

(x) Transportation corridor.

With the focus of the HIA was on both general and specific public health issues, the project involved a comprehensive assessment of health risks over the various phases of infrastructure development and were reasonably linked to the potential impact areas of concern. These health risks were:

(i) Respiratory disease-including but not exclusive to acute respiratory infections and tuberculosis;

(ii) Vector borne diseases-including but not exclusive to malaria, typhus, and dengue;

(iii) Sexually transmitted infections-including but not exclusive to HIV and AIDS, genital ulcer disease, syphilis, gonorrhea, chlamydia, and hepatitis B;

(iv) Soil and water borne diseases-including but not exclusive to soil transmitted helminths, leptospirosis, schistosomiasis, meliodosis, and cholera;

(v) Accidents-including but not exclusive to traffic, and construction;

(vi) Food and nutrition-including but not exclusive to stunting, wasting, micronutrient diseases changes in agricultural practices, and gastroenteritis;

(vii) Exposure to hazardous materials-including but not exclusive to pesticides, inorganic and organic fertilizers;

(viii) Health services-including but not exclusive to physical infrastructure, and staffing levels;

(ix) Psychosocial-including but not exclusive to relocation, violence, and security concerns;

(x) Cultural practices-includes the role of traditional medical providers, indigenous medicines and unique cultural health practices.

Source: Nam Theun 2 Power Company. Nam Theun Report Documents. 
Table 28: Transport

\begin{tabular}{|c|c|c|}
\hline $\begin{array}{l}\text { Health Outcome } \\
\text { Category }\end{array}$ & Health Concern & Context \\
\hline \multirow[t]{4}{*}{$\begin{array}{l}\text { Communicable } \\
\text { diseases }\end{array}$} & Malaria & $\begin{array}{l}\text { Focal distribution associated with specific ecosystems. } \\
\text { Roads through forests in Southeast Asia may increase } \\
\text { malaria risk. In South Asia roadside ditches may } \\
\text { provide malaria mosquito breeding sites. }\end{array}$ \\
\hline & $\begin{array}{l}\text { STIs, and HIV } \\
\text { and AIDS }\end{array}$ & $\begin{array}{l}\text { Large construction sites with migrant labor and/or } \\
\text { camp followers or poor peripheral communities and } \\
\text { gender inequality. Truck stops along major highways }\end{array}$ \\
\hline & $\begin{array}{l}\text { Acute and chronic } \\
\text { respiratory } \\
\text { infections }\end{array}$ & $\begin{array}{l}\text { Air pollution associated with motorized vehicles } \\
\text { burning fossil fuels and with fugitive dust. Most } \\
\text { important pollutants are very fine particulates and } \\
\text { nitrogen dioxide. }\end{array}$ \\
\hline & Zoonoses & Transport of domestic animals. \\
\hline \multirow[t]{7}{*}{$\begin{array}{l}\text { Noncommunicable } \\
\text { diseases }\end{array}$} & $\begin{array}{l}\text { Respiratory } \\
\text { diseases such as } \\
\text { bronchitis, asthma }\end{array}$ & $\begin{array}{l}\text { Air pollution associated with motorized vehicles } \\
\text { burning fossil fuels. Most important pollutants are very } \\
\text { fine particulates, nitrogen oxide. }\end{array}$ \\
\hline & Cancers & $\begin{array}{l}\text { Air pollution associated with motorized vehicles } \\
\text { burning fossil fuels. Most important pollutants are very } \\
\text { fine particulates, nitrogen oxide. }\end{array}$ \\
\hline & $\begin{array}{l}\text { Cardio-vascular } \\
\text { diseases }\end{array}$ & $\begin{array}{l}\text { Air pollution associated with motorized vehicles } \\
\text { burning fossil fuels. Most important pollutants are very } \\
\text { fine particulates. }\end{array}$ \\
\hline & Poisoning & $\begin{array}{l}\text { Pollution from motorized vehicles in exhaust fumes, } \\
\text { brakes and run-off. Includes lead poisoning. Leakage } \\
\text { of hazardous chemicals in transport. }\end{array}$ \\
\hline & Hearing loss & Prolonged exposure to high noise levels \\
\hline & $\begin{array}{l}\text { Stunting of } \\
\text { children's lungs }\end{array}$ & Air pollution \\
\hline & $\begin{array}{l}\text { Dust-related } \\
\text { diseases }\end{array}$ & Airborne dust thrown up by vehicles \\
\hline \multirow[t]{2}{*}{ Nutritional issues } & Undernutrition & $\begin{array}{l}\text { Loss of livelihoods from resettlement and from climate } \\
\text { change }\end{array}$ \\
\hline & Overnutrition & $\begin{array}{l}\text { Overweight and obesity associated with lack of } \\
\text { physical exercise. Use of private motorized transport } \\
\text { can be a key contributing factor. }\end{array}$ \\
\hline \multirow[t]{2}{*}{ Injuries } & Road traffic injuries & $\begin{array}{l}\text { Road design and use. Control of construction vehicles. } \\
\text { Lack of crossing points. Speed controls. }\end{array}$ \\
\hline & Falls and crushing & Inadequate safety systems on construction sites. \\
\hline \multirow[t]{4}{*}{$\begin{array}{l}\text { Mental health and } \\
\text { well-being }\end{array}$} & Well-being & $\begin{array}{l}\text { Increased access to family and friends, goods and } \\
\text { services, employment opportunities }\end{array}$ \\
\hline & $\begin{array}{l}\text { Stress, anxiety, } \\
\text { depression }\end{array}$ & $\begin{array}{l}\text { Disruption and change associated with construction or } \\
\text { resettlement. } \\
\text { Prolonged exposure to high noise levels. Community } \\
\text { separation. }\end{array}$ \\
\hline & $\begin{array}{l}\text { Mental } \\
\text { development }\end{array}$ & $\begin{array}{l}\text { Lead and other pollutants in emissions. Prolonged } \\
\text { exposure to high noise levels. }\end{array}$ \\
\hline & Dementia & Suspected association with air pollution \\
\hline
\end{tabular}

STIs = sexually transmitted infections.

Source: Sustainable Development and Climate Change Department, Asian Development Bank. 


\section{Box 11: Eindu to Kawkareik Road Improvement Project, Myanmar}

The project consists of the improvement of a 65-kilometer road section that is part of the Greater Mekong Subregion (GMS) East-West Economic Corridor linking Myanmar to Viet Nam through Thailand and the Lao People's Democratic Republic. An initial environmental examination identified potential health impacts including HIV transmission and road safety. The health impact assessment identified other community health risks including malaria drug resistance. This is emerging in border regions across the GMS, including the Myanmar-Thailand border where this project is located. Mobile populations, such as construction workers, can facilitate its spread. Should artemisinin combination therapy resistance spread from Myanmar to Bangladesh and India, further spread to Africa is likely to occur, potentially reversing decades of malaria control efforts and billions of dollars invested in African countries. Infrastructure projects in areas of artemisinin combination therapy resistance need to pay particular attention to this issue, involve the relevant health authorities and jointly address these specific health risks associated with hard to reach populations such as mobile workers.

Economic corridors have also been associated with the spread of sexually transmitted diseases, including HIV, during their operation. As connectivity improves, the risk of infection increases among transport workers, truck drivers, and crews working along major road corridors and local communities via worker interactions with commercial sex workers. While mobility and migration are not, by themselves, risk factors for HIV, they create circumstances that increase vulnerability to HIV, and pose barriers to prevention, treatment and care. The new transport corridors inevitably give rise to border towns, localized economic hubs, and growth centers that attract rural migrants and foster high-risk behaviors. Women and girls from poor, ethnic minorities living in isolated and remote rural settings are at a significantly higher risk of HIV infection. They often lack alternative means of employment, empowerment, and adequate education on sexual and reproductive health. Experience and lessons from other economic corridors in the GMS points to the need for a more integrated approach to managing social and health risks. The health sector should be involved in developing, implementing and monitoring a management plan, and community participation and engagement should be promoted. Adequate financial resources should be allocated.

Sources: ADB. 2015. Greater Mekong Subregion East-West Economic Corridor Eindu to Kawkareik Road Improvement Project: Report and Recommendation of the President.Manila; ADB. 2015. GMS East-West Economic Corridor Eindu to Kawkareik Road Improvement Project: Initial Environmental Examination. Manila; ADB. 2010. Practice Guidelines for Harmonizing HIV Prevention Initiatives in the Infrastructure Sector: Greater Mekong Subregion. Manila.; M. Inkoshasan et al. 2015. HIV Vulnerability and Service Availablility in Mobility Settings of Myawaddy and Kawkareik.; and WHO. 2016. Approaches for Mobile and Migrant Populations in the Context of Malaria Multi-Drug Resistance and Malaria Elimination in the Greater Mekong Subregion.. 
Table 29: Urban Development

\begin{tabular}{|c|c|c|}
\hline $\begin{array}{l}\text { Health Outcome } \\
\text { Category }\end{array}$ & Health Concern & Context \\
\hline \multirow[t]{8}{*}{$\begin{array}{l}\text { Communicable } \\
\text { diseases }\end{array}$} & Malaria & $\begin{array}{l}\text { Only transmitted in urban areas in South Asia. Mosquito breeds in a wide } \\
\text { variety of settings such as domestic water storage, garden ponds, roof } \\
\text { tanks, roadside ditches. }\end{array}$ \\
\hline & Dengue & $\begin{array}{l}\text { The mosquito breeds in containers of clean water. Wide distribution, } \\
\text { largely urban. Severe epidemics. Association with domestic drinking water } \\
\text { storage, urban construction sites, drip trays, discarded solid waste. }\end{array}$ \\
\hline & Lymphatic filariasis & $\begin{array}{l}\text { Most common form associated with urban and peri-urban areas, where } \\
\text { the mosquito vector breeds in organically polluted water. Association with } \\
\text { sanitation and sanitation safety. Association with blocked drains and lack of } \\
\text { solid waste management. }\end{array}$ \\
\hline & Zika & Same mosquito as for dengue. \\
\hline & $\begin{array}{l}\text { Diarrhea and other } \\
\text { gastrointestinal } \\
\text { infections }\end{array}$ & $\begin{array}{l}\text { Clean and abundant drinking water supplies and improved hygiene reduce } \\
\text { risk. Food contamination reduced by washing. Many pathogens associated } \\
\text { with sewage. Safe use of wastewater is encouraged and there are guidelines. } \\
\text { Association with flooding and drought, intermittent piped water supply } \\
\text { systems, poor latrines and open defecation, water supply safety and } \\
\text { sanitation safety, poor environmental health services, and poor food safety. }\end{array}$ \\
\hline & $\begin{array}{l}\text { Sexually transmitted } \\
\text { infections }\end{array}$ & $\begin{array}{l}\text { Associated with poverty and inequality, including gender inequality, rapid } \\
\text { social change, urban migration, substance abuse. }\end{array}$ \\
\hline & $\begin{array}{l}\text { Acute and chronic } \\
\text { respiratory infections }\end{array}$ & $\begin{array}{l}\text { Associated with crowding, high population densities, poor ventilation, } \\
\text { indoor air pollution, poor outdoor air quality. }\end{array}$ \\
\hline & Viral epidemics & $\begin{array}{l}\text { Associated with crowding, hygiene, lack of preparedness, transport } \\
\text { systems. }\end{array}$ \\
\hline $\begin{array}{l}\text { Noncommunicable } \\
\text { diseases }\end{array}$ & $\begin{array}{l}\text { A complex of } \\
\text { cardiovascular, } \\
\text { respiratory, and } \\
\text { endocrine diseases } \\
\text { and cancers }\end{array}$ & $\begin{array}{l}\text { Associated with poor physical and social environments, learned behaviors } \\
\text { and living conditions, as well as genetic disposition, age and gender, } \\
\text { and allergens. Affected by town planning, improved transport systems, } \\
\text { access to green space, quality of public realm, housing design. Air and } \\
\text { water pollution, hazardous trades, substance abuse. More prevalent than } \\
\text { communicable diseases in urban settings. }\end{array}$ \\
\hline \multirow[t]{2}{*}{ Nutritional issues } & Undernutrition & $\begin{array}{l}\text { Significant side effect of diarrhea and other gastrointestinal infections. } \\
\text { Associated with a lack of food safety and security, high food prices, poor } \\
\text { access to fresh and appropriate foods. }\end{array}$ \\
\hline & Overnutrition & $\begin{array}{l}\text { Associated with a sedentary lifestyle, lack of active travel opportunities, } \\
\text { foods containing high levels of refined sugars, flours, processed meats and } \\
\text { fats, poor access to fresh and appropriate foods. Causes a wide range of } \\
\text { noncommunicable diseases. }\end{array}$ \\
\hline \multirow[t]{5}{*}{ Injuries } & Road Traffic Injuries & $\begin{array}{l}\text { Associated with poorly designed public realm, including lack of footpaths } \\
\text { and cycleways, crossing points, and public transport. }\end{array}$ \\
\hline & Falls and crushing & $\begin{array}{l}\text { Inadequate safety systems on construction sites. Poor construction traffic } \\
\text { management. Poor construction practices. Poor design of staircases. }\end{array}$ \\
\hline & Burns & Hazardous trades, poor cooking facilities. \\
\hline & Drowning & Flood-prone areas. \\
\hline & Heat stress & Associated with temperature extremes and poor housing quality. \\
\hline \multirow[t]{2}{*}{$\begin{array}{l}\text { Mental health and } \\
\text { well-being }\end{array}$} & Well-being & $\begin{array}{l}\text { Improvements associated with urban employment opportunities, equitable } \\
\text { access to goods and services, good housing and public realms, green and } \\
\text { blue space, and supportive neighborhoods. }\end{array}$ \\
\hline & $\begin{array}{l}\text { Stress, anxiety, } \\
\text { depression, } \\
\text { substance abuse }\end{array}$ & $\begin{array}{l}\text { Disruption and change associated with construction. Prolonged exposure } \\
\text { to high noise levels. Severance. Long and difficult commuting. Poverty and } \\
\text { inequality, overcrowding, urban migration, insecurity, fear of theft and } \\
\text { violence, and corruption. }\end{array}$ \\
\hline
\end{tabular}

Source: Sustainable Development and Climate Change Department, Asian Development Bank. 
Table 30: Agricultural Development and Irrigation

\begin{tabular}{|c|c|c|}
\hline $\begin{array}{l}\text { Health Outcome } \\
\text { Category }\end{array}$ & Health Concern & Context \\
\hline \multirow[t]{6}{*}{$\begin{array}{l}\text { Communicable } \\
\text { diseases }\end{array}$} & Malaria & $\begin{array}{l}\text { Poorly designed irrigation infrastructure, lack of proper } \\
\text { drainage, reduction of livestock, tree crops }\end{array}$ \\
\hline & Lymphatic filariasis & $\begin{array}{l}\text { Rural vectors have similar requirements to malaria } \\
\text { vectors }\end{array}$ \\
\hline & Leptospirosis & Zoonosis associated with aquatic rodents \\
\hline & $\begin{array}{l}\text { Japanese } \\
\text { encephalitis }\end{array}$ & $\begin{array}{l}\text { Associated with farming systems that include rice } \\
\text { and pigs }\end{array}$ \\
\hline & Other zoonoses & Livestock, animal husbandry \\
\hline & Diarrheal diseases & $\begin{array}{l}\text { Pollution from livestock waste (Cryptosporidium, } \\
\text { Amoebiasis) }\end{array}$ \\
\hline \multirow[t]{2}{*}{$\begin{array}{l}\text { Noncommunicable } \\
\text { diseases }\end{array}$} & $\begin{array}{l}\text { Pesticides } \\
\text { poisoning }\end{array}$ & $\begin{array}{l}\text { Domestic storage of pesticides, poor application } \\
\text { procedures }\end{array}$ \\
\hline & Poisoning & Associated with excessive mineralization \\
\hline Nutritional issues & Undernutrition & $\begin{array}{l}\text { Associated with transition from subsistence to } \\
\text { commercial crops }\end{array}$ \\
\hline \multirow[t]{3}{*}{ Injuries } & $\begin{array}{l}\text { Crushing and } \\
\text { cutting }\end{array}$ & $\begin{array}{l}\text { Accidents related to mechanization or livestock } \\
\text { husbandry }\end{array}$ \\
\hline & Drowning & Night storage tanks in irrigation schemes \\
\hline & $\begin{array}{l}\text { Communal } \\
\text { violence }\end{array}$ & Ownership and control of irrigation infrastructure \\
\hline \multirow{2}{*}{$\begin{array}{l}\text { Mental health and } \\
\text { well-being }\end{array}$} & Well-being & Abundant food, security of tenure, access to markets \\
\hline & $\begin{array}{l}\text { Stress, anxiety, } \\
\text { depression, } \\
\text { substance abuse }\end{array}$ & $\begin{array}{l}\text { Associated with easy access to pesticides, insecurity of } \\
\text { tenure, cost of farming inputs, uncertain markets }\end{array}$ \\
\hline
\end{tabular}

Source: Sustainable Development and Climate Change Department, Asian Development Bank.

\section{Communities}

121. Human communities are divided into many groups with different vulnerabilities to project impacts. Vulnerability is determined by inequality, marginalization, poverty, gender, ethnicity, occupation, and more. If the most vulnerable groups are safeguarded, then other members of a project affected community are also likely to be safe.

\section{Gender, Age, Poverty, and Inequality}

122. There are often substantial differences in disease prevalence rates associated with gender, age, and poverty. Gender and age specific disease rates are recorded in national health statistics. Very often the data are not disaggregated by poverty, or socioeconomic status. The effect of poverty and inequality is apparent wherever special studies have been made and is referred to as the social gradient in health. ${ }^{66}$

${ }^{66}$ WHO. 2008. Commission on Social Determinants of Health - Final Report. 
123. Poverty is a complex and circular determinant of health as ill-health leads to poverty and poverty leads to ill-health, creating a downward spiral. For example, the poor may have to:

(i) wittingly overuse the natural resources at their disposal to meet their basic needs, suffering malnutrition;

(ii) live in unsafe locations subject to flood, landslide, crime, or increased risk of malaria;

(iii) take time off work to care for sick family members and lose income;

(iv) accept hazardous occupations with a high risk of injury or disease;

(v) accept high interest loans to receive medical treatment or meet other basic needs; or

(vi) commute longer distances between home and work, reducing caring time for their families.

124. As another example, air pollution is experienced unequally by the rich and poor. High income groups can afford to live in and spend leisure time in areas that have lower levels of air pollution that are away from industry and large roads. In contrast, poor income groups often find that the cheapest or unused land is near industry or roads where air pollution is higher.

125. As the World Commission on the Social Determinants of Health states (footnote 66):

In countries at all levels of income, health and illness follow a social gradient: the lower the socioeconomic position, the worse the health.

126. Figure 9 illustrates the social gradient in the association between disease rates and wealth (socioeconomic status). Community health impacts are often distributed in a similar manner. A similar phenomenon is observed between countries. In low-income countries, an increase in average wealth is strongly correlated with an increase in average health. Figure 10 illustrates the relationship at one time and this is known as the Preston curve [graph from ${ }^{67}$ ]. An animated version of this figure, which indicates the trajectories over time, can be found on the GapMinder website.

\section{Workforce}

127. OHS and CHS are substantially different concepts that require different management systems. OHS is managed within the fence where everything is under the direct control of the project managers including the actual construction activities. CHS is managed outside the fence, where people have more freedom to behave as they wish. The same distinction is made in the environmental sourcebook (footnote 5).

128. OHS has many international and national agreements, standards, and management procedures. These include risk assessments that can be done separately or after HIA since it requires details that preliminary construction methodologies and plans may have. The International Labor Organization (ILO) promotes standards through protocols, conventions, codes of practice, and training materials. ${ }^{68}$ There is guidance for specific sectors, risks, and vulnerable worker communities. The communities include migrant workers, waste collectors, agricultural workers, home workers, and small construction site workers. ILO

${ }^{67}$ K. Pickett and R. Wilkinson. 2009. The Spirit Level: Why More Equal Societies Almost Always Do Better.

${ }^{68}$ International Labor Organization (ILO). International Labour Standards on Occupational Safety and Health. 
Figure 9: Example of Socioeconomic Status and Community Health

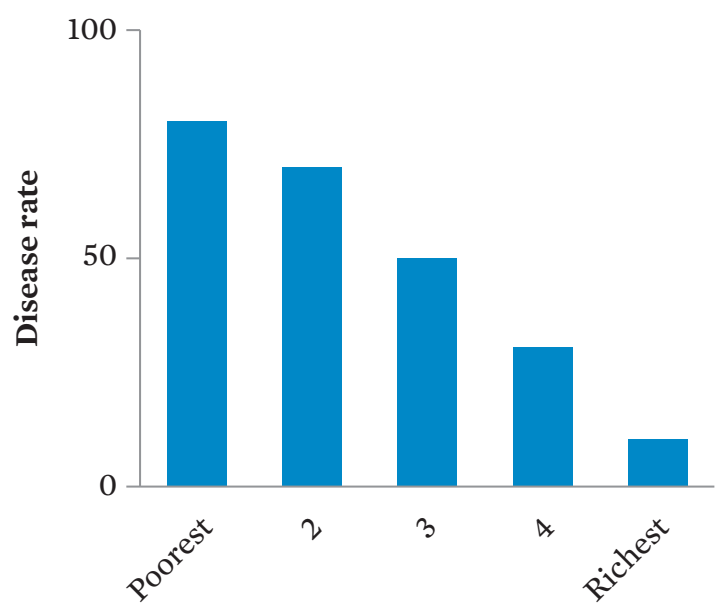

Wealth

Source: Sustainable Development and Climate Change Department, Asian Development Bank.

Figure 10: Average Life Expectancy at Birth Versus National Income per Capita

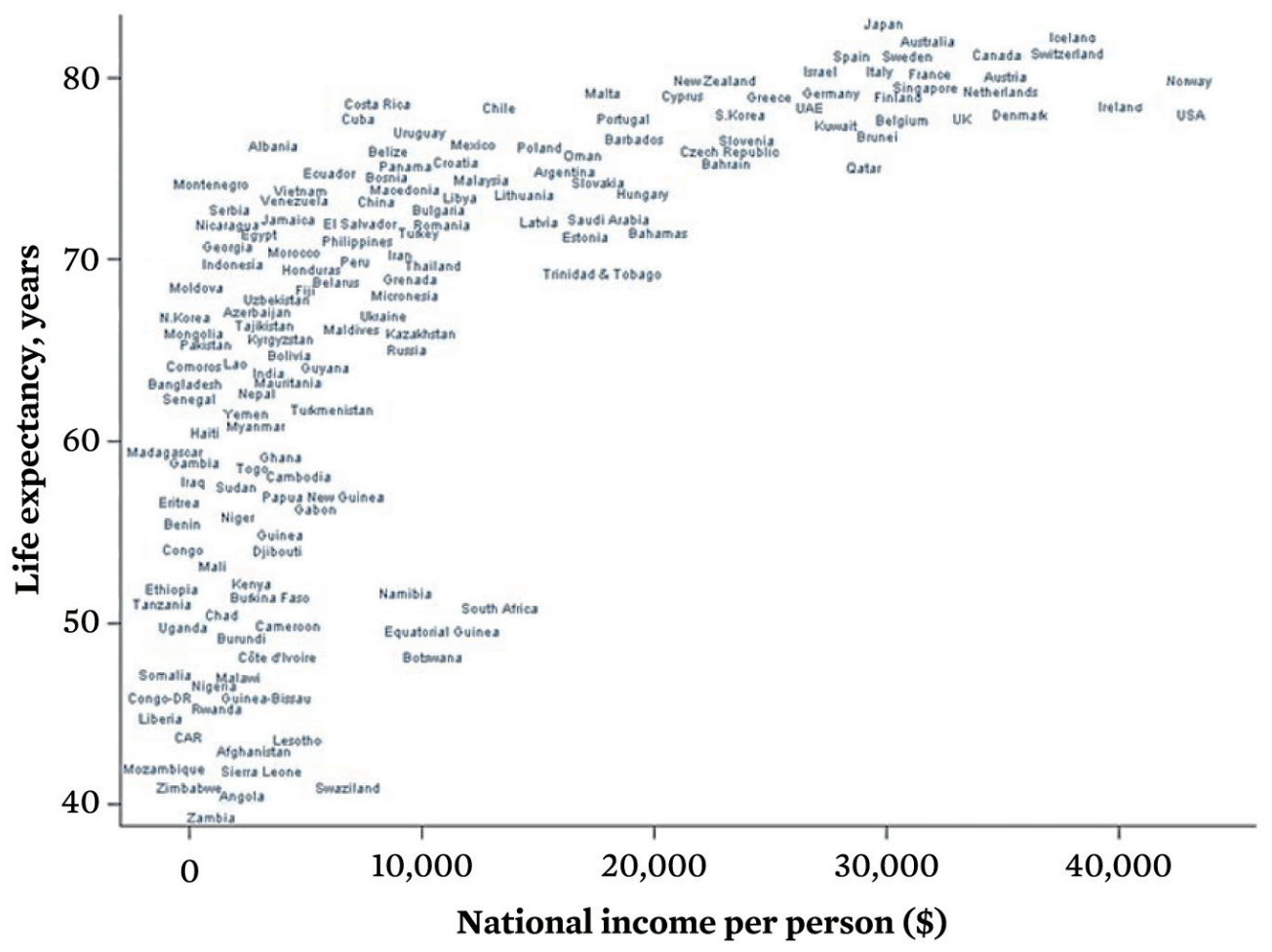

Source: K. Pickett and R. Wilkinson. 2009. The Spirit Level: Why More Equal Societies Almost Always Do Better. 
published a survey of good practice in the Association of Southeast Asian Nations (ASEAN) member countries in $2009^{69}$ that includes frameworks, enforcement guidelines, outreach, training, and research. WHO maintains a list of papers on occupational health topics. ${ }^{70}$ There is also an ASEAN international collaboration on occupational safety and health network (ASEAN-OSHNET). The focus of OHS programs appears to be the established workplace and its risk assessment. There is no reference to proactive risk assessment of planned infrastructure development.

129. Several international standards bodies have collaborated to produce Occupational Health and Safety Series (OHSAS) $18000 .^{71}$ This is an international occupational health and safety management system specification. It is intended to help organizations to control occupational health and safety risks and is available as an online toolkit. It enables an organization to

(i) establish an OHS management system to eliminate or minimize risk to employees and other interested parties who may be exposed to OHS risks associated with its activities;

(ii) assure itself of its conformance with its stated OHS policy;

(iii) demonstrate such conformance to others;

(iv) implement, maintain, and continually improve an OHS management system;

(v) make a self-determination and declaration of conformance to this OHSAS specification; and

(vi) seek certification/registration of its OHS management system by an external organization.

130. The International Standards Organization (ISO) is developing an OHS standard as ISO $45001^{72}$ and this is expected to be consistent with ILO guides and OHSAS 18000. Other standards include EU-OSHA in the European Union and the equivalent OSHA from the United States Department of Labor.

131. The status of occupational health and safety in Asia varies between countries and is correlated with their gross domestic product (GDP). Countries with low GDP tend to have high occupational fatality levels. Some countries have major shortcomings in OHS laws and regulations, and lack of enforcement and compliance. All of them have national improvement programs that are reported by ILO. For example:

(i) Viet Nam Ministry of Labor, Invalids and Social Affairs established national programs on OHS for 2006-2010 and 2011-2015. ${ }^{73}$ This included multiple objectives such as training, prevention, provision of health care to workers, awareness raising, and monitoring. The ministry has published an evaluation of the first five-year plan.

69 T. Fang Qun and T. Kawakami. 2009. The ASEAN Occupational Safety and Health Network: Good Occupational Safety and Health Practices 2008/2009.

${ }^{70}$ WHO. 2017. Occupational Health Topics.

71 OSHA. OHSAS 18001 and 18000 Occupational Health and Safety.

72 ISO. ISO 45001. 2017. Occupational Health and Safety.

73 ILO. 2012. National Programme on Occupational Safety and Occupational Health in Period of 2011-2015 by Government of Vietnam. 
(ii) Thailand launched its first masterplan in 2001. A government resolution to improve worker safety and health was adopted in 2007. A national profile on OHS was published in 2012. ${ }^{74}$ The occupational accident rate peaked in 2004-2005 and fell steadily to 2011. Strategies for improving OSH include capacity development, standards, laws, management systems, and monitoring.

132. HIA consultants cannot be expected to be experts in OHS. It is a separate discipline with its own training, certification, body of knowledge, and opportunities for experience. An HIA can simply ensure that gaps and overlaps are identified and managed appropriately. This includes the following considerations.

(i) Construction and operating companies have in place an OHS management system and this usually includes a responsible officer.

(ii) The OHS management system includes a risk assessment at the planning stage.

(iii) Requests to tender for construction contracts include provision for OHS.

(iv) The OHS management system extends to all levels of subcontractors. Performance is actively reported and monitored to ensure continuous implementation.

(v) The OHS management system includes a mitigation hierarchy. This hierarchy places the obligation for maintaining a safe work place on the project managers rather than the individual workers and subcontractors. The provision of protective equipment is necessary but not sufficient. Specific requirements are enumerated in Appendix 4construction OHS checklist.

(vi) OHS management is conventionally limited to the period of employment. Many construction workers originate from different parts of a country or region, or from different countries. Scoping takes into consideration the possibility that workers returning to their places of origin carry with them pathogens (and, importantly, strains of pathogens with antimicrobial resistance) to remote communities.

(vii) Outside of the work environment, the workforce and their families form an additional community group and are exposed to the health risks and opportunities of the project. They also interact with other community groups, creating additional health impacts.

(viii) An overlap between OHS and CHS management is likely to occur during the construction phase of infrastructure projects. The workforce mixes with the local community, creating challenges such as malnutrition, commercial sex, community violence, road traffic injury, trespass, and price inflation.

\section{Setting Boundaries}

133. The spatial and temporal boundaries of an HIA represent compromises between where and when important health risks or opportunities will occur, and the resources that can realistically be invested into the HIA. Even when health is considered within an EIA context, the boundaries for health impacts may differ from those for environmental impacts. There may be environmental impacts in areas that are not populated and so do not have health impacts. Impacts on human health may expand beyond the areas where the environmental impacts occur, because of human circulation, migration, or resettlement.

\footnotetext{
${ }^{74}$ Ministry of Labour of Thailand, Department of Labour Protection and Welfare. 2012. National Profile on
} Occupational Safety and Health of Thailand 2012. 


\section{Spatial Boundary}

134. The spatial boundary of the HIA takes account of where people come from and go to (Box 12). This is particularly important for communicable diseases with direct transmission between people, such as STIs. Setting the boundary also takes account of natural transport mechanisms such as wind (pollution, vectors) and water (pollution, pathogens), linear features such as roads, and locations of settlements and towns.

135. There are differences between natural boundaries (ecosystems, hydrology, land use patterns) and administrative boundaries (provinces, districts). HIA consultants are likely to find that the health outcome datasets are clustered by administrative boundary or the catchment of a health center, and are therefore hard to aggregate with datasets on health determinants that use natural boundaries.

\section{Box 12: Scoping a Highway}

Scoping bias is a common challenge. For example, a rural highway project in Europe set the scope of the environmental impact assessment to 250 meters around the highway's alignment. The project included a segregated cycle and walkway for nonmotorized users. The highway ended at a busy intersection some 2 kilometers from the city. There was no safe cycleway from there to the city center. The spatial boundary of the health impact assessment was expanded to include this section.

Source: Sustainable Development and Climate Change Department, Asian Development Bank.

\section{Temporal Boundary}

136. The potential community health impacts will differ between pre-project, construction, operation, and decommissioning phases. The HIA considers each of these project phases in turn. For example, at the pre-project phase, there may be involuntary resettlement of communities, or stagnation of local economic activity (planning blight). During the construction phase, there may be a substantial influx of temporary construction workers, camp-followers, and secondary industries. The operational phase may only require a small workforce and there may be a "boom-and-bust" effect as the demand for construction work ceases, and construction workers and camp followers depart. The health outcomes of the project vary with time. Some impacts occur rapidly, such as malaria, while others are not evident for many decades, such as cancers. The degree of uncertainty about impacts naturally increases with the time horizon. The scope should also take account of seasonality. Many diseases are seasonal and associated with wetter or drier conditions. These conditions may change, for example, the abundance and longevity of vector mosquitoes may be more important during wet weather and the concentration of air pollutants may be greater in dry weather. 
137. The decommissioning phase is usually outside of ADB's control and may be 30-40 years in the future. Relatively little can be said about it, other than recommending:

(i) A new HIA at that time;

(ii) Careful archiving of project information; and

(iii) Insurance and bond posting, to prevent abandonment.

138. Abandonment occurs when infrastructure no longer produces economic returns and there are no resources for proper decommissioning. Abandoned factories may contain many hazards such as rusting containers full of dangerous chemicals, deep shafts and ponds, unsafe floors, asbestos sheeting, and sharp edges. Special programs are often required to clean up such sites and these must often be paid for by local and national governments. 


\section{Terms of Reference}

139. The final output of the scoping stage is a terms of reference (TOR) for a consultant to undertake an HIA. In practice, there are often a series of activities associated with a project and each may require the services of consultants and a separate TOR. The activities include the following.

(i) Reconnaissance missions,

(ii) Project design missions,

(iii) Rapid HIA, and

(iv) Feasibility studies.

140. The activities are likely to be initiated through the environmental safeguards or PSA processes. Generic TORs have been developed under the assumption that a public health specialist with the appropriate HIA competency is being added to a mission that includes a wide range of other specialists (Appendix 3). The TORs for public health are intended to ensure that health and safety is addressed in a competent manner. Key elements include:

(i) The HIA lead must have a strong public health background (public health education, such as a Master's degree in Public Health), training in HIA, and relevant experience in public health and HIA. Skills should include gender-sensitivity, speaking the local language, and capabilities to interact with people with different cultural backgrounds (Section IVB).

(ii) The assessment should conform with the definitions, procedures, methods, and concepts provided in this book, and explain when divergence is necessary.

(iii) The public health TOR below are assumed to be embedded in a larger TOR that includes additional administrative requirements.

(iv) Each TOR is divided by: knowledge, skills, and experience; management; scope; and method.

(v) The health consultant refines the scope based on knowledge of similar projects, the scientific literature, the opinions of stakeholders, baseline conditions, and personal experience. 


\section{Health Baseline}

\section{Summary}

- The functions of baseline data

- The nature of health data

- Social surveys

- The challenge of biomedical data collection

141. Community health assessments usually include a description of baseline conditions. This may be called a community health profile. It is generally required for the reasons listed in Table 31.

142. It is not practical to produce a complete generic list of data to collect during a baseline survey. The key principle is to avoid collecting data indiscriminately. The data should be collected for a specific purpose that is clearly identified in the primary and secondary functions listed above. The health baseline usually includes information on both health outcomes and health determinants at national, regional, district, and where possible, project site levels. Table 32 illustrates the health baseline conditions that may be encountered in a poor community.

\section{A. Health Statistics}

143. Government health statistics regularly update and present data about rates of death and illness, and their common causes. Governments report these to WHO, which summarizes

\section{Table 31: Primary and Secondary Functions of Health Baselines}

Primary
$\begin{aligned} & \text { - As a status report on the existing health determinants and outcomes in } \\ & \text { the project affected community, that helps to inform the identification, } \\ & \text { characterization, and prioritization of impacts; }\end{aligned}$
- As a basis for developing health indicators to use during monitoring;
- As an assessment of the adequacy of current health services and of the need to
strengthen them.
$\begin{aligned} & \text { Secondary } \\ & \text { function }\end{aligned}$
$\begin{aligned} & \text { - As a contribution to an assessment of the health needs of the existing } \\ & \text { community and how they should be managed; } \\ & \text { although attribution is usually difficult and expensive. }\end{aligned}$

Source: Sustainable Development and Climate Change Department, Asian Development Bank. 


\section{Table 32: Examples of Health Baseline Conditions That Might Be Found in a Poor Community}

\begin{tabular}{ll} 
Category & \multicolumn{1}{c}{ Examples } \\
Common causes of & - Acute respiratory infections \\
illness in children & - Malaria \\
& - Diarrhea \\
Common causes of & - Road traffic and other accidents \\
death in adults & - Heart disease \\
& - Chronic respiratory infection \\
Health determinants & - The percentage of homes with access to safe drinking water \\
& - The percentage of homes with adequate sanitation \\
& - The percentage of children sleeping under an insecticide-treated net ${ }^{\mathrm{a}}$ \\
& - The number of road traffic accidents
\end{tabular}

${ }^{a}$ Improved mosquito net.

Source: Sustainable Development and Climate Change Department, Asian Development Bank.

them, for every country, on its website. Similar information is usually available for regions, provinces, and cities, and sometimes for local areas. None of the health outcome data should be assumed to be accurate and it is usually not suitable for before-and-after comparisons of health outcomes associated with the project. It is useful for understanding the current health status of a community, for identifying the key relevant health determinants and for assessing community needs. It provides a starting point for constructing simple indicators that can be used for monitoring. See Section XIIIB for more details about indicators.

144. Health statistics are generally measured in absolute numbers, proportions and as rates. Both proportion and rate data enable comparisons to be made over time, between areas and between community groups. For example, the rate of infant mortality is 50 per 1,000 live births, recorded violent crime is 100 per 100,000 population; emergency hospital admissions are 200 per 10,000 population; early deaths from cardiovascular disease is 200 per 100,000 population.

145. A proportion is the percentage of a disease or condition and is calculated from the number of people with a disease or condition divided by the size of the exposed population multiplied by a 100. Examples include: percentage of children vaccinated against measles, percentage of women who gave birth last year, percentage of new lung cancer cases in adult men per year.

146. A rate is the number of people with a disease or condition divided by the size of the exposed population multiplied by a standard population size e.g., 1,000; 10,000 or 100,000. A distinction is made between prevalence rate and incidence rate. The prevalence rate is the proportion at a given time and the incidence rate is the proportion of new cases within a given time period. Rate data enables comparisons to be made over time, between localities, and between community groups. These rates vary with the community group, by age, gender, ethnicity, socioeconomic circumstances, and location. Disaggregated data of this kind are often not collected routinely and the size of the exposed community group is often not known with accuracy. 


\section{Box 13: Health Impact Assessment of a Large Industrial Project in the People's Republic of China}

The plans for the project construction phase of a large industrial project foresaw an increase in heavy vehicles on small rural roads. The baseline study tried to establish the number and location of road traffic accidents. The local police stated that they had no records that any road traffic accidents had occurred. The local hospital stated that road traffic accidents were the primary cause of visits to accident and emergency units. This illustrates the value of triangulating baseline information.

Source: Sustainable Development and Climate Change Department, Asian Development Bank.

147. Sometimes published specialist academic studies are available that include project locations. The data gathered in these studies has been collected for research purposes and to a high standard of accuracy and reliability. It is often disaggregated by age, sex, and ethnicity. Whenever possible, data is triangulated in order to improve reliability: similar data from independent sources is compared (Box 13). Large differences suggest inaccuracies.

148. Primary data on human health status, through biomedical measurements, are not usually collected for HIA baselines (Box 14). To do so is expensive, requires a long time, and is subject to ethical restrictions. In this sense, community health surveys differ from ecological surveys and biological sampling. The ethical considerations require clearance from a medical ethics committee or ministry of health, as happens in Thailand and Viet Nam, ${ }^{75}$ for example. Ethical requirements include: a rigorous statistical design; free, prior, informed consent; a

\section{Box 14: Primary Data Collection for the Health Impact Assessment of a Gas Plant in a Pakistan Desert}

Relatively little health data were available about the communities in the locality in Pakistan. A special budget was obtained from the project owner to remedy this as part of the social investment program, intended for strengthening health clinics. A university was contracted to do the sampling and analysis. The sampling design and objectives were submitted to the university medical ethics committee for approval. Anemia rates in local adult women were sampled using finger pricks and portable analyzers. The socioeconomic status of the women was ranked by ownership of standard objects. There was a gradient of anemia rates by distance from the nearest town and by socioeconomic status.

The health impact assessment recommended that the survey could be repeated at the end of the construction period. As the consultant was no longer contracted to the project after construction, there is no information available regarding the outcome.

Source: F. Viliani and M. Birley. 2010. Desert Gas Project.

\footnotetext{
75 Viet Nam Ministry of Health. 2013. On Promulgation of Regulation on Organization and Operation of Council of
} Ethics in Biomedical Research at Grass-Root Level. 
robust confidentiality procedure; and a referral protocol for cases of illness detected. On the other hand, it is often relatively easy to survey some of the main health determinants, such as those listed in Table 32, without medical research ethics approval.

149. National statistics on health determinants are often based on sampling methods that do not provide accurate local information at project level. For example, the national datasets on access to safe drinking water and basic sanitation, collected for monitoring progress toward the MDGs, are based on Multiple Indicator Cluster Surveys-surveys of randomly selected clusters of households. ${ }^{76}$ Simple local surveys can be arranged to count physical assets such as insecticide-treated nets, taps, housing quality, and toilets. Other determinants of health can be assessed through social surveys. Such surveys can also support an assessment of household wealth based on the possession of different assets: a mobile telephone, a television, a washing machine, a vehicle, a brick house.

150. Projects may introduce new risks, reduce old ones, and change a community's perceptions of existing and future health risks. They may also introduce new community groups with different health conditions. These new groups and their health status will not be in the health baseline because their size and origin is unknown. For these reasons, the health baseline is just one of several sources of information used to assess health impacts.

\section{B. Community Consultation and Social Surveys}

151. Public consultation and information disclosure are emphasized in ADB's safeguards policy statement (footnote 4). The elements of good community consultation are described in the environment safeguards, involuntary resettlement, and indigenous people sourcebooks and referred to as public communication and information, education, and communication. The questions and approach are cleared in advance by the community engagement officer associated with the project, if there is one. The results of community consultation are likely to identify new health concerns that should be included in the impact analysis.

152. The value attached to community consultation varies between countries. From a technical perspective, it is one of the best ways of gathering information about the health concerns of a community, the options for mitigation and health enhancement, and the general acceptability of the project. It is also an important mechanism for managing the risk perceptions of a community, which links to their mental health and well-being. Countries may have specific requirements for the form, content and timing of community consultation in HIA. For example, Thailand has made community consultation a legal requirement in HIA. The Government of the Lao PDR has emphasized public participation through a number of articles provided in the constitution, laws, decrees, notices, and guidelines.

153. Social surveys conducted as part of EIA and social impact assessment can provide an indication of health concerns. Additional health questions may be added to these surveys by the HIA team. Such surveys often use tools like focus groups and social mapping. An indirect approach may be preferred which does not include the word health. Open questions are often preferable to closed questions. Great sensitivity to local culture is required when framing health questions. For example, it may be inappropriate to ask questions about sexual

${ }^{76}$ UNICEF. 2017. Multiple Indicator Cluster Survey. 


\section{Box 15: Community Survey of Health Concerns Associated with a Waste-To-Energy Project in England}

The proposal was to build a new waste-to-energy plant, with combined heat and power, to replace an aging incinerator. The new plant would be built on a coastal promontory. The health impact assessment (HIA) team expected a high level of public anxiety as the dioxin emissions of old incinerators are well-known. The existing incinerator had a dioxin footprint, measured from soil samples. The public was consulted using telephone interviews and random sampling. A set of open-ended questions was designed. The first question was:

Considering the information you've just heard, what do you think the top three potential positive and top three potential negative impacts of the incinerator will be on you, your friends and family?

The answers from 456 respondents were coded by topic and expressed as the project will lead to this getting better or getting worse. The most common answers, as percentages follow.

\section{Most common responses}

$\begin{array}{lcc}\text { Coded Answers } & \text { Get Worse } & \text { Get Better } \\ \text { The view from the waterfront } & 38 \% & \\ \text { Traffic congestion } & 34 \% & 5 \% \\ \text { Air quality } & 22 \% & 38 \% \\ \text { Odor/smells } & 19 \% & 20 \% \\ \text { Noise pollution } & 13 \% & 9 \% \\ \text { Standard of living } & 11 \% & 13 \% \\ \text { No impact } & 11 \% & 37 \% \\ \text { Traffic accidents } & 10 \% & 2 \%\end{array}$

Participants were also asked:

What do you think the potential effects of the incinerator are likely to be on your family's health and well-being?

The most common answers were as follows.

\section{Community opinion about the health impact of an incinerator}

\begin{tabular}{|c|c|}
\hline Coded Answer & $\%$ \\
\hline No potential effects/Will not affect me & $53 \%$ \\
\hline Don't know/not sure & $13 \%$ \\
\hline Change in well-being or quality of life & $10 \%$ \\
\hline Respiratory disease e.g. asthma & $10 \%$ \\
\hline Improvement/Positive Effect & $9 \%$ \\
\hline Stress/depression or mental illness & $7 \%$ \\
\hline Increase in cancer rates & $4 \%$ \\
\hline Accident rates & $3 \%$ \\
\hline Circulatory disorders e.g., heart attacks, strokes & $2 \%$ \\
\hline
\end{tabular}

The survey also found that less than $50 \%$ of the respondents had confidence in the local government. Respondents were asked if they wish to be involved in air pollution monitoring or part of a management committee. But this was not strongly supported.

The HIA recommended more regular communication about the proposal, including public exhibitions and opportunities to visit the working facility. All of this would help to manage perception of risk and increase confidence. The proposal already included good plans for traffic management and pollution control.

Source: M. Birley et al. 2008. A Prospective Rapid Health Impact Assessment of the Energy from Waste Facility in the States of Jersey. 
or sanitation behavior. The following are examples of health questions that can be included in social surveys.

(i) Have any of your children had diarrhea in the last 7 days?

(ii) Where do you take your children when they are sick?

(iii) What medicines can you get from your local health clinic, pharmacy, or local store?

(iv) What are the main causes of illness in your household?

(v) How safe do you feel?

(vi) Are condoms easily available?

(vii) Where do you get your drinking water and how do you store it?

(viii) What kind of sanitation do you have?

(ix) Can you suggest how this project may affect you and your family?

(x) Are there any locations that you think are more or less suitable for this project?

(xi) What, if anything, concerns you about this project? 


\section{Applicable Policy, Legal, and Administrative Framework and Standards}

\section{Summary}

- Distribution of responsibilities between government ministries

- The challenges of international standards

- The need for regional harmonization, especially for transboundary projects

154. An HIA report includes a summary of the applicable policies, laws, administrative framework, and standards that apply in the country or countries, where the project is located. Responsibility for managing the impacts of new infrastructure development projects usually resides in the ministry of environment and is specified in environmental legislation. One of the purposes of EIA is to safeguard human health. The ministry of labor may be responsible for occupational health and safety and the ministry of social work may have additional responsibilities that are relevant for community health and safety. This creates a challenge as protecting and promoting population health is the main responsibility of the ministry of health. A memorandum of intent, understanding, or agreement may be available between the relevant ministries that clearly delineates the responsibilities of each. The ADB HIA project has actively promoted closer cooperation between ministries and WHO have promoted memoranda of understanding to support HIA.

155. In the case of some health determinants, there are normative international standards developed by WHO and based on scientific evidence. National standards are often derived from these international standards taking into account attainable economic, technical, and political criteria. Such national standards are often available for air and water quality and set acceptable thresholds. Health effects may still be significant at concentrations that are well below the threshold. HIA requirements may vary between neighboring countries, and there is a growing need for harmonization to manage transboundary projects.

\section{A. Harmonization in Transboundary Projects}

156. The Asia and Pacific region is developing rapidly and there is increased attention to transboundary projects such as highways and economic corridors. There are also projects near national boundaries that have transboundary impacts, such as power transmission and hydropower reservoirs, coal-fired power plants, special economic zones, and industrial complexes. 
157. Such projects comply with the national laws, norms, and standards of each country, as well as the norms and standards of the lending agency. It is advisable to develop a consensus about the scope and process of HIA both between ministries of health and environment within each country, and between ministries in neighboring countries. Such a consensus ultimately depends on the ministers themselves and their deliberations at ministerial level. At a technical level, it may be possible to obtain agreement about the standard content of HIA guidelines and the definition of terms used.

158. Transboundary HIAs are likely to include the following considerations.

(i) Agreement of a common impact assessment framework by each government that includes EIA and HIA.

(ii) Agreement by governments and lending agencies on funding of the HIA and whether a unified report will be produced.

(iii) A mechanism enabling responsible ministries in each country to engage in a bilateral discussion on the scope and TOR for the HIA.

(iv) A contractual arrangement with one or more HIA lead consultants. This may require a national, regional, or international consultancy who have experienced HIA staff, to oversee the whole assessment. Alternatively, each country may recruit its own lead consultants, and ADB may issue a unified TOR, and provide a mechanism for cooperation and coordination.

(v) Recruitment of national HIA consultants in each affected country who are familiar with their country's relevant laws, health data systems. They should have a public health background and recommended HIA competency level 2-4 (Table 11).

(vi) Collection, analyses, summaries, and comparisons of relevant environmental and public health legislation and regulation from each affected country, identifying gaps, differences and agreements. A consensus is developed as to what regulatory standards and principles are used as benchmarks by the HIA and the project.

(vii) Security clearance from each government to enable consultants to visit border areas, as necessary.

(viii) Access to relevant datasets in each country.

(ix) Collection, summaries, and comparisons of baseline health data from each side of the border.

(x) Mapping of the project location, with transportation routes, administrative units, and human settlements in each affected country.

(xi) Conducting of HIA-related community consultations in national and ethnic minority languages.

(xii) Consultations with key stakeholders in administrative units within each affected country.

(xiii) Engagement with other related impact assessment teams, such as EIA teams, and cross-reference their documents in assessment reports. 


\section{Impact Analysis}

\section{Summary}

- Transforming a long list of health opportunities and concerns into a short list of health benefits and risks

- What can and cannot be quantified

- The challenge of prioritization

- Residual risks

- Example of questions to ask during the construction phase

- The nature of cumulative impacts including climate change

- Consideration of resettlement, influx, and indigenous people's needs

159. An HIA may be produced alone or it may be integrated in an environmental impact statement. The objective of the analysis is to identify significant health benefits and risks that require attention and to make justifiable recommendations to manage them. Health benefits and risks arise through changes to the determinants of health. For example: there are health benefits in improving the socioeconomic status of a community through access to work or training; travel routes can be safer and quicker; access to social services can be improved. Examples of changing health determinants that increase health risks include: increased density of vector breeding sites, inhalation of high levels of air pollution, interaction between pedestrians and heavy traffic, price inflation of local foods, and anxiety and conflict arising from the project.

160. The method of analysis proceeds from a long list of health opportunities and health concerns to a short list of health benefits and risks. The long list is obtained by combining the health baseline, literature review, stakeholder and community opinion, experience of other projects, understanding of the project design, and any other appropriate sources of information. The shortlist is obtained by attaching significance to each of the items on the long list. These are the expected impacts.

161. There are different methods for attaching significance to the impacts of a project component on the health of a specific community group during a particular project phase. Some methods simply judge whether an impact is minor, moderate or major, and positive or negative. Other methods judge the geographic extent, intensity, magnitude, sensitivity, severity and likelihood and use this to rank impact significance. Table 33 illustrates what a simple impact table looks like. Each of the conclusions should be supported by text. For example, the likelihood of the suicide rate increasing is judged to be low because the community have 
Table 33: Example of the Elements of a Simple Summary Impact Table

\begin{tabular}{|c|c|c|c|c|c|}
\hline $\begin{array}{l}\text { Health Concern or } \\
\text { Opportunity }\end{array}$ & $\begin{array}{c}\text { Community } \\
\text { Group }\end{array}$ & Likelihood & Severity & $\begin{array}{l}\text { Significance of } \\
\text { Benefit or Risk }\end{array}$ & Certainty \\
\hline Increase in STIs & $\begin{array}{l}\text { Marginalized } \\
\text { women }\end{array}$ & High & High & High & High \\
\hline $\begin{array}{l}\text { Reduction in road } \\
\text { traffic accidents }\end{array}$ & All road users & Low & High & Moderate & High \\
\hline $\begin{array}{l}\text { Increased access to } \\
\text { safe drinking water }\end{array}$ & $\begin{array}{l}\text { Households } \\
\text { within the } \\
\text { project area }\end{array}$ & High & High & High & Moderate \\
\hline Increased suicide rate & $\begin{array}{l}\text { Women } \\
\text { agricultural } \\
\text { workers }\end{array}$ & Low & High & Moderate & Low \\
\hline $\begin{array}{l}\text { Increased occurrence } \\
\text { of muscoloskeletal } \\
\text { disorder }\end{array}$ & $\begin{array}{l}\text { Construction } \\
\text { workers }\end{array}$ & High & Moderate & Moderate & High \\
\hline
\end{tabular}

STIs = sexually transmitted infections.

Source: Sustainable Development and Climate Change Department, Asian Development Bank.

demonstrated plenty of coping strategies. There is uncertainty about whether the projectrelated changes will overwhelm these coping strategies. Severity is high because one or more deaths are involved. The significance is scored as moderate and recommendations are needed to reduce the significance. Recommendations are discussed under mitigation and enhancement measures.

162. There is a tendency to mix up the existing health needs of a community with the impacts attributable to the project. The general health needs of a community are the responsibility of the ministry of health. The health impacts of the project are the responsibility of the project owner and the regulatory authority. The outlook on the communities' future health status must be communicated to the health sector to support a process of redirection and targeted capacity development. For example, they may wish to expand the local health clinic before an influx of workers and camp followers.

163. The analysis prioritizes the impacts (Box 16). Recommendations are then made to enhance positive health impacts (benefits) and mitigate negative health impacts (risks). The recommendations for mitigating negative impacts are presumed to reduce the impacts and, if possible, eliminate them. The residual impacts must then be assessed and a judgment made on whether they have been reduced as low as reasonably practical. The residual health risk is assessed under the assumption that the recommendations are implemented. Table 34 illustrates a simple residual risk analysis. The objective is to reduce the residual risk to low or zero. If this cannot be accomplished then the issue is flagged for further consideration. The analysis of community health impacts is generally qualitative. For some health outcomes and associated health determinants a quantitative analysis can also be undertaken. 


\section{Box 16: Health Impact Assessment of a Large Industrial Project in a Water-Poor Region of the Middle East}

The project planned to extract industrial water from a nearby river as well as from other sources. The river flow was reduced by upstream extraction and a damaged watershed. The impoverished local community depended on the river for domestic and agricultural water. The health baseline indicated that gastro-intestinal infections were common and severe in children. There was no hydrological model from which to estimate how much river water could be abstracted safely. The health impact assessment identified opportunities to reduce the incidence of gastrointestinal infections and increase agricultural food production if the overall water management master plan recognized and addressed the needs for improved domestic and irrigation water supplies. The health impact assessment recommended developing a proper hydrological model to study abstraction and a strategic switch to alternative sources of water, even if these were more expensive.

Source: M. Birley, S. Vohra, and B. Ahmad. 2012. HIA of oil projects in Iraq. Annual meeting of the IAIA. Portugal.

Table 34: Example of the Elements of a Residual Risk Analysis

\begin{tabular}{llll} 
Health Concern & \multicolumn{1}{c}{ Significance } & \multicolumn{1}{c}{ Recommendations } & \multicolumn{1}{c}{ Residual Risk } \\
$\begin{array}{l}\text { Increase in sexually } \\
\text { transmitted infections }\end{array}$ & High & $\begin{array}{l}\text { See mitigation and } \\
\text { enhancement measures }\end{array}$ & Moderate \\
$\begin{array}{l}\text { Reduction in road traffic } \\
\text { accidents }\end{array}$ & Moderate & As above & Low \\
Increased suicide rate & Moderate & As above & Low
\end{tabular}

Source: Sustainable Development and Climate Change Department, Asian Development Bank.

\section{A. Quantification}

164. Quantification, where possible, provides a more precise assessment of the likely health impacts, and additional justification to the project owners to support the management of the health impacts. Quantification requires scientific consensus on a quantitative relationship between a health outcome and a health determinant, additional local or modelled data on health outcomes and health determinants, additional time and additional budget. It is usually only practical for environmental health determinants such as pollution. Table 35 provides examples of health determinants and related health outcomes that can be quantified. Where quantification is possible, an economic analysis of benefits and costs may be made (Box 17).

165. Health determinants are easier to quantify than health outcomes. Examples include:

(i) Concentration of $\mathrm{PM}_{10}$ in urban air,

(ii) Number of households with reliable access to safe and clean drinking water,

(iii) Number of insecticide-treated nets in use,

(iv) Number of road traffic accidents recorded, and

(v) The price inflation of basic goods and services in a locality. 


\section{Table 35: Examples of Quantification of Health Outcomes}

\begin{tabular}{|c|c|}
\hline Determinant & Outcome \\
\hline Air pollution & $\begin{array}{l}\text { There is a strong scientific consensus on the concentration-response function } \\
\text { between outdoor air pollution and some key diseases. The concentration-response } \\
\text { function can be used to estimate the change in the number of deaths and illnesses } \\
\text { associated with a specific concentration of a monitored parameter such as } \mathrm{PM}_{10} \text {, } \\
\mathrm{PM}_{2.5}, \mathrm{NOx}, \mathrm{SO}_{2} \text {. } \\
\text { The concentration-response function for air pollution has no safe level or } \\
\text { threshold. Every level of air pollution has some effect on health outcomes. }\end{array}$ \\
\hline Water pollution & $\begin{array}{l}\text { There are concentration-response functions for key industrial chemicals and } \\
\text { microorganisms. However, these are not often used in health impact assessments } \\
\text { because attribution of changes in health outcomes linked to water pollution or } \\
\text { contamination is strongly influenced by individual and community behavior } \\
\text { around drinking water and food hygiene. }\end{array}$ \\
\hline
\end{tabular}

$\mathrm{NO}_{\mathrm{x}}=$ nitrogen oxide, $\mathrm{PM}_{10}$ = particulate matter of less than 10-micron diameter, $\mathrm{PM}_{2.5}$ = particulate matter of less than 2.5-micron diameter, $\mathrm{SO}_{2}=$ sulfur dioxide.

Source: WHO. 2016. Ambient (outdoor) Air Quality and Health .

\section{B. Questions to Ask}

166. A skilled HIA practitioner will approach an impact analysis from different perspectives. These will vary between the project phase, sector, and location. For this reason, it is not practical to provide a comprehensive list of questions to ask. However, the construction stage of many projects has common features and Table 36 provides a starting point. The table focuses on high-level questions about management plans that should be in place if community health and safety is to be protected. Each management plan may have many elements.

\section{Cumulative Impacts}

167. Cumulative health impacts occur at local, national, and global scales. Local cumulative health impacts occur when different development projects are co-located. The impacts of one project may be insignificant but the impact of many projects may be significant. For example, one micro-dam may not influence mosquito populations sufficiently to significantly enhance vector-borne disease transmission, but a project to construct numerous micro-dams in an area may increase vector-borne disease transmission. The management of local cumulative impacts is strengthened by undertaking a strategic assessment that includes human health.

168. Cumulative impacts should be distinguished from in-combination impacts. In-combination impacts occur when two or more health determinants work together in a single project. For example, the in-combination impacts of air pollution and noise on cardiovascular disease, or the in-combination impacts of an increase in the price in medicines and greater difficulty in accessing health services. The two acting together (in-combination) are likely to be worse than each affect acting singly. 


\section{Box 17: Quantifying the Health Costs of Air Pollution}

The health costs of changes in air quality can be partially quantified and then costed or valuated. To undertake this analysis within an health impact assessment, the scope needs to be defined (in coordination with the environmental impact assessment) in terms of (i) the pollutants of interest, (ii) the health outcomes under assessment, (iii) the geographical and population boundaries, and (iv) the temporal scope.

Quantitative risk assessment uses (i) the concentration-response functions (CRF) on the association between a certain level of exposure to an air pollutant and its health impact, as identified in the scientific research literature; (ii) the change in concentration of the air pollutant; (iii) the size of population exposed; and (iv) the baseline rate for the health outcome under assessment e.g., mortality rate. This method provides estimates for the number of attributable cases of a health outcome, for example number of hospital admissions.

More sophisticated methods are also available, such as life table calculations, that provide estimates in terms of years of life lost or gained, or a change in the average life expectancy of the affected population as a whole.

Air pollution can lead to a wide range of mortality and morbidity effects but only some are quantifiable. WHO has produced CRFs for particulates, nitrogen dioxide and ozone. There is also well accepted evidence to support the quantification of health risks of exposure to other air pollutants, including air toxics (e.g., benzene). The lifetime increased risk of cancer from exposure to certain air toxics can be calculated. It is also possible to estimate the association between sulfur dioxide and respiratory morbidity.

The estimated health effects can be monetized. Attributable deaths and hospital admissions are most often monetized. Other outcomes that can be monetized include medication use, and restricted activity days (days when people find they can do less home or work activities). Attributable deaths are monetized by multiplying the number of deaths by the value of a statistical life, or the number of life years lost by the value of a statistical life year. This captures the societal or welfare costs. Hospital admissions are monetized by multiplying the number of hospital admissions by the average cost of each admission and these can be interpreted as health sector costs. A recent study estimated that deaths from air pollution cost the global economy about $\$ 225$ billion in lost labor income and more than $\$ 5$ trillion in welfare losses in 2013.

Sources: F. Hurley et al. 2005. Methodology for the Cost-Benefit Analysis for CAFE: Volume 2: Health Impact Assessment.; US EPA. 1991. Risk Assessment for Toxic Air Pollutants: A Citizen's Guide.; WHO/EURO. 2013. Review of Evidence on Health Aspects of Air Pollution (REVIHAAP); WHO. 2013. Health Risks of Air Pollution in Europe - HRAPIE Project. Recommendations for Concentration-Response Functions for Cost-Benefit Analysis of Particulate Matter, Ozone and Nitrogen Dioxide; and World Bank. 2016. The Cost of Air Pollution: Strengthening the Economic Case for Action. 
Table 36: General Health Questions During Construction Phase

\begin{tabular}{|c|c|c|}
\hline Category & Questions & Yes/No \\
\hline \multirow{2}{*}{$\begin{array}{l}\text { Occupational } \\
\text { health and } \\
\text { safety }\end{array}$} & Is there an OHS management plan? & \\
\hline & Does it cover all tiers of subcontractors? & \\
\hline \multirow[t]{2}{*}{$\begin{array}{l}\text { Resettlement } \\
\text { and Influx }\end{array}$} & $\begin{array}{l}\text { Is there a plan for managing resettlement and its associated health } \\
\text { impacts? }\end{array}$ & \\
\hline & $\begin{array}{l}\text { Is there a plan to manage population influx and associated health } \\
\text { impacts? }\end{array}$ & \\
\hline $\begin{array}{l}\text { Hazardous } \\
\text { materials }\end{array}$ & $\begin{array}{l}\text { Are there plans for the safe transport, storage, and disposal of } \\
\text { hazardous materials? }\end{array}$ & \\
\hline \multirow[t]{3}{*}{$\begin{array}{l}\text { Emissions and } \\
\text { waste }\end{array}$} & $\begin{array}{l}\text { Will emissions and wastes during construction be managed to a } \\
\text { standard that is acceptable to the Asian Development Bank? }\end{array}$ & \\
\hline & $\begin{array}{l}\text { Have the temporary effects of pollution and nuisance associated with } \\
\text { construction been identified and is there a management plan? }\end{array}$ & \\
\hline & $\begin{array}{l}\text { Does the construction plan include measures to reduce greenhouse } \\
\text { gas emissions significantly? }\end{array}$ & \\
\hline \multirow{4}{*}{$\begin{array}{l}\text { Communicable } \\
\text { diseases }\end{array}$} & Will workers be screened and treated on recruitment? & \\
\hline & $\begin{array}{l}\text { Are there policies and plans to avoid discrimination on medical } \\
\text { grounds? }\end{array}$ & \\
\hline & $\begin{array}{l}\text { Will the construction site management include measures to control } \\
\text { vector breeding such as the mosquitoes that transmit dengue fever? }\end{array}$ & \\
\hline & $\begin{array}{l}\text { Is there a management plan to prevent additional STIs for the } \\
\text { workforce and all subcontractors (such as condom distribution)? }\end{array}$ & \\
\hline \multirow[t]{2}{*}{$\begin{array}{l}\text { Local } \\
\text { procurement }\end{array}$} & $\begin{array}{l}\text { Are there plans to maximize the local procurement of goods and } \\
\text { services and to assist secondary providers with loans and training? }\end{array}$ & \\
\hline & $\begin{array}{l}\text { Can price inflation be monitored and procurement adjusted } \\
\text { accordingly? }\end{array}$ & \\
\hline \multirow[t]{3}{*}{ Transport } & $\begin{array}{l}\text { Is there a transport management plan that assures community } \\
\text { transport safety? }\end{array}$ & \\
\hline & $\begin{array}{l}\text { Does the plan include both construction vehicles and community } \\
\text { vehicles? }\end{array}$ & \\
\hline & Are temporary diversions planned to prevent transport barriers? & \\
\hline $\begin{array}{l}\text { Disadvantaged } \\
\text { groups }\end{array}$ & $\begin{array}{l}\text { Have the special health needs of disadvantaged groups been identified } \\
\text { and managed? }\end{array}$ & \\
\hline \multirow{3}{*}{$\begin{array}{l}\text { Encroachment } \\
\text { and land take }\end{array}$} & Have all cultural and spiritual sites been identified and protected? & \\
\hline & $\begin{array}{l}\text { Are there management plans to protect common land used for } \\
\text { recreation, grazing, subsistence farming, or collection of water, wild } \\
\text { foods, and herbal medicines? }\end{array}$ & \\
\hline & $\begin{array}{l}\text { Will there be barriers to prevent the community encroaching on the } \\
\text { construction site? }\end{array}$ & \\
\hline $\begin{array}{l}\text { Catastrophic } \\
\text { failure }\end{array}$ & $\begin{array}{l}\text { Is there a contingency plan to avoid, prevent, and contain catastrophic } \\
\text { failures of engineering structures that would affect human health? }\end{array}$ & \\
\hline \multirow[t]{2}{*}{$\begin{array}{l}\text { Medical } \\
\text { services }\end{array}$} & $\begin{array}{l}\text { Is there a protocol to determine when local health centers can call for } \\
\text { assistance from construction camp medical services, and vice-versa? }\end{array}$ & \\
\hline & Have local medical services been notified about the project? & \\
\hline
\end{tabular}

OHS = occupational health and safety, STIs = sexually transmitted infections.

Source: Sustainable Development and Climate Change Department, Asian Development Bank. 
169. National cumulative impacts are most evident in the extractive sector (oil, gas, minerals), forestry, commercial plantations, and hydropower. When a country relies on a small number of natural resources for a large part of its income there may be economic destabilization and a deterioration in community health status. One sector of the economy booms and this causes price inflation that excludes other sectors of the economy and the communities that work in them. One possible remedy is the creation of a sovereign fund, as has happened in Norway.

170. Global cumulative impacts are linked to a project's contribution to global changes such as carbon dioxide $\left(\mathrm{CO}_{2}\right)$ concentrations, water scarcity, and overload of nitrogen and phosphorus cycles. These are all vital to safeguarding human health and well-being. Major projects that consume fossil fuels contribute to rising $\mathrm{CO}_{2}$ concentrations. These include thermal power stations, internal combustion engines, and industrial processes such as cement and fertilizer production. Rising $\mathrm{CO}_{2}$ concentrations contribute to climate change. WHO refers to this as a public health emergency. Atmospheric $\mathrm{CO}_{2}$ concentrations are already at a historic high; temperature extremes and other climatic events, such as typhoons and reducing river flows, are already creating health impacts. ${ }^{77}$ Food insecurity, changing monsoons, and coastal flooding are expected to affect the health and safety of many millions of people in Asia ${ }^{78}$ and elsewhere. ${ }^{79}$ Table 37 indicates some of the health impacts of climate change. The economic costs of climate change are very high. ${ }^{80}$ For example, an initiative to mitigate the health impacts of climate change estimated that it had saved $\$ 5.7$ billion between 2009 and 2017. ${ }^{81}$ The net health benefits included preventing:

(i) 300-830 early deaths among adults,

(ii) 39,000-47,000 lost work days,

(iii) 35-390 non-fatal heart attacks,

(iv) 8,200-9,900 asthma flare-ups,

(v) 180-220 hospital admissions, and

(vi) 200-230 asthma emergency room visits.

171. Global cumulative health impacts are hard to mitigate at a project level. An HIA therefore refers to the national and international policies and strategies with which the project must comply (Box 18). A balanced approach to mitigation of and adaptation to climate change is desirable. It is unlikely that infrastructure development can be adapted to withstand the effect of food shortages and major sea level rises that are expected. Projects that reduce national $\mathrm{CO}_{2}$ emissions are likely to help mitigate climate change and may have positive health impacts. For example, in the urban transport sector, the co-benefits of change are widely acknowledged. Fossil fuel consumption not only contributes to climate change, but also produces black carbon and other air pollutants that contribute to local health impacts. Policies that promote a modal shift from private car use to active travel not only reduce emissions of $\mathrm{CO}_{2}$ and other air pollutants; they also increase mental and physical health

${ }^{77}$ K. Bush et al. 2011. Impacts of Climate Change on Public Health in India: Future Research Directions. Environ Health Perspect. 119(6). pp. 765-770.

78 ADB. 2011. Accounting for Health Impacts of Climate Change.Manila.

79 J. Kumaresan, P. Jai, and S. Nalini. 2011. Climate Change and Health in South East Asia. Int J Clim Change Strateg Manag. 3 (2). pp. 200-208.

${ }^{80}$ WHO. 2017. Climate Change and Health.

${ }^{81}$ The Medical Society Consortium on Climate and Health (MSCCH). 2017. Report: Medical Alert! Climate Change Is Harming Our Health The Medical Society Consortium on Climate and Health (MSCCH). 
Table 37: Some Health Impacts of Climate Change

\begin{tabular}{|c|c|}
\hline $\begin{array}{l}\text { Effect of } \\
\text { Climate Change }\end{array}$ & Health Impacts \\
\hline Extreme heat & $\begin{array}{l}\text { Heat-related illness and death from heat stroke and dehydration. It also } \\
\text { can make some chronic diseases worse }\end{array}$ \\
\hline $\begin{array}{l}\text { Extreme } \\
\text { weather }\end{array}$ & $\begin{array}{l}\text { Injury, displacement, and death. Extreme weather events can knock out } \\
\text { power and phone lines, damage or destroy homes, and reduce the availability of } \\
\text { safe food and water. They also can damage roads and bridges, impeding access to } \\
\text { medical care and separating people from their medicines. Stomach and intestinal } \\
\text { illnesses tend to increase following extreme weather and associated power } \\
\text { outages. }\end{array}$ \\
\hline Air pollution & $\begin{array}{l}\text { Increases asthma and allergy attacks, and can lead to other illnesses, } \\
\text { hospitalizations, and deaths. Increase in wildfires, pollen levels, mold. }\end{array}$ \\
\hline $\begin{array}{l}\text { Vector-borne } \\
\text { diseases }\end{array}$ & $\begin{array}{l}\text { Increase in the number and geographic range of disease carrying mosquitoes, } \\
\text { fleas, ticks. Diseases including Zika, Dengue, Chikungunya, and other arboviruses. }\end{array}$ \\
\hline $\begin{array}{l}\text { Contaminated } \\
\text { water }\end{array}$ & $\begin{array}{l}\text { Higher water temperatures, heavier downpours, rising sea levels, and more } \\
\text { flooding can lead to contamination of drinking water, recreational waters, fish, } \\
\text { and shellfish. }\end{array}$ \\
\hline $\begin{array}{l}\text { Contaminated } \\
\text { water }\end{array}$ & $\begin{array}{l}\text { Increases in temperature, humidity, and extreme weather events like heavy } \\
\text { downpours and flooding can lead to food becoming contaminated by bacteria and } \\
\text { toxins. }\end{array}$ \\
\hline Mental health & $\begin{array}{l}\text { Many people exposed to the worst extreme weather events experience stress and } \\
\text { serious mental health consequences including depression, anxiety, post-traumatic } \\
\text { stress disorder, increases in suicidal thoughts and behavior, and substance abuse. }\end{array}$ \\
\hline Nutrition & $\begin{array}{l}\text { In the presence of more carbon dioxide, plants produce less protein and more } \\
\text { starch and sugar, and they take in fewer essential minerals. Higher temperatures } \\
\text { can also result in more food spoiling. Drought can damage or destroy crops, and } \\
\text { extreme weather events can disrupt food production and distribution by knocking } \\
\text { out power, damaging infrastructure, and delaying food shipments. As a result, food } \\
\text { can be damaged, spoiled or contaminated, reducing the availability of and access } \\
\text { to safe and nutritious food }\end{array}$ \\
\hline
\end{tabular}

Source: Sustainable Development and Climate Change Department, Asian Development Bank.

through an increase in physical activity, lower transport congestion, and reduced inhalation of pollutants.

\section{Associated Assessments}

172. HIA is usually undertaken in parallel with a range of other assessments. In addition to environmental assessment, the social assessments may include management plans for resettlement, migration, and indigenous peoples. Each of these may have its own health impacts. 


\section{Box 18: Cumulative Health Impacts of Special Economic Zones in the Greater Mekong Subregion}

The development of special economic zones (SEZs) and economic corridors in countries within the Greater Mekong Subregion (GMS) has been set as a priority to achieve a long-term vision of growth, prosperity and acceleration of regional development. The focus is on taking advantage of and enhancing economic opportunities, trade, infrastructure, and business development while enhancing regional strengths to link to major markets beyond the GMS. As of 2015, there were over 500 SEZs within the GMS (excluding the People's Republic of China) with the majority located in Viet Nam.

An overarching goal of SEZ development is to improve development opportunities and benefits to regions outside of capital centers. They are strategically placed to take advantage of cross-border collaboration and transient populations are to be expected. Depending on the nature of the zone and the nationality, businesses can include manufacturing, heavy industry, tourism and textile/garment production. SEZs are culturally diverse locations. SEZs can have unique cumulative health impacts for local communities and workers, if left unidentified and unmanaged. The health determinants of potential cumulative health impacts include the following.

(i) Mixed residential and industrial land use without appropriate buffer zones;

(ii) Airborne emissions of water pollution, noise, light and vibration;

(iii) Inadequate local health services to be able to provide preventive, diagnosis and treatment care to both workers and community members;

(iv) The inability of emergency preparedness and response sector to respond appropriately to industrial and community accidents;

(v) Conflicts between residents and project workforce;

(vi) Resettlement and households that are subjected to resettlement multiple times;

(vii) Worker accommodations being in poor conditions and/or located in vulnerable areas;

(viii) Inadequate and ineffective waste management strategies;

(ix) Disorganized and chaotic industrial and local traffic;

(x) Poor knowledge, attitudes, and practices related to communicable diseases amongst community members and workers;

(xi) Poor coping and personal health practices such as alcohol and drug abuse;

(xii) Human trafficking;

(xiii) Poverty;

(xiv) Lack of basic needs being met including access to safe water, sanitation, shelter, security, and safe food.

Sources: ADB. 2016. Review of configuration of the Greater Mekong Subregion Economic Corridors. Manila; ADB. 2016. The Role of Special Economic Zones in Improving Effectiveness of GMS Economic Corridors. Manila; and ADB. 2018. A Health Impact Assessment Framework for Special Economic Zones in the Greater Mekong Subregion. Manila. 
Table 38: Health Challenges and Impacts of Resettlement

$\begin{array}{ll}\text { Challenges } & \text { - Poor location of new settlement } \\ & \text { - Loss of livelihood } \\ & \text { - Loss of community cohesion } \\ \text { Health impacts } & \text { - Malaria epidemic } \\ & \text { - Malnutrition } \\ \text { - Communal and domestic violence and injury } \\ \text { - Substance abuse and gambling } \\ \end{array}$

Source: Sustainable Development and Climate Change Department, Asian Development Bank.

\section{Resettlement and Influx}

173. Some projects in the Asia and Pacific region require the involuntary resettlement of established communities or give rise to a population influx, leading to the creation of new communities. Both processes cause health impacts whether they occur on a large or small scale. Resettlement planning and management systems are well established. ${ }^{82}$ Resettlement plans often include their own initial environmental examination. They can also include an HIA. The challenges of resettlement are immense ${ }^{83}$ and the adverse health effects can last for several generations ${ }^{84}$ (Table 38 ).

174. Population influx planning and management may be required for large projects. The challenges are even greater than for resettlement as the influx is unintended. Construction sites attract informal settlers, or camp followers, looking for economic opportunities. They are often unskilled and seek to sell food, alcohol, drugs, and sex. The operational phase of projects attracts different kinds of informal settlers. For example, reservoir projects attract fishing folk from distant fisheries. They profit from the upsurge in fish populations associated with the release of nutrients in new reservoirs. There may be seasonal migrations linked to the agricultural cycle. Informal settlers and camp followers are scoped into the HIA because they experience the health impacts generated by a project and also generate additional health impacts on existing communities and the project workforce that are unrelated to project activities (Table 39).

\section{Indigenous People}

175. ADB has specific assessment and management systems for safeguarding indigenous peoples. ${ }^{85}$ Indigenous people may experience health impacts of new projects sited on their ancestral lands in many different ways (Box 19). They may be especially vulnerable to the effects of a population influx. For example, they may contract communicable diseases for which they have no acquired immunity. The enforced changes to their way of life may affect mental health and well-being, increase psychosocial disorders, and reduce community cohesion.

${ }^{82}$ ADB. 2014. Involuntary Resettlement. Manila.

${ }^{83}$ World Commission on Dams. 2016. Dams and Development: A New Framework for Decision-Making.

${ }^{84}$ T. Scudder. 2011. Resettlement Outcomes of Large Dams.

${ }^{85}$ ADB. 2014. Indigenous Peoples. Manila. 


\section{Table 39: Health Impacts and Management Measures for Influx}

\begin{tabular}{|c|c|}
\hline Heal & $\begin{array}{l}\text { - Additional burden on public services such as water supply, sanitation, and waste } \\
\text { management } \\
\text { - Informal settlements selling food, alcohol, and sex } \\
\text { - Community violence } \\
\text { - Exploitation of migrant labor } \\
\text { - Encroachment } \\
\text { - Importation of new infections }\end{array}$ \\
\hline $\begin{array}{l}\text { Influx } \\
\text { management }\end{array}$ & $\begin{array}{l}\text { - Acknowledge that it will happen and work with project team and local } \\
\text { governments to manage medical service requirements } \\
\text { - If possible, define sites for informal settlers and their landlords in collaboration } \\
\text { with local governments, to reduce exploitation } \\
\text { - Identify likely access routes such as roads and linear structures, } \\
\text { - Enforce orderly worker recruitment procedures which prevent recruitment } \\
\text { onsite } \\
\text { - Provide water supply and sanitation } \\
\text { - Account for a future community during impact assessment } \\
\text { - Conduct strategic environmental and social assessment of special economic } \\
\text { zones by governments to ensure a structured management of worker and } \\
\text { informal settler influx }\end{array}$ \\
\hline
\end{tabular}

Source: Sustainable Development and Climate Change Department, Asian Development Bank.

\section{Box 19: Resettlement Mismanagement and Indigenous People}

During the 1980s, an indigenous community in Sarawak were displaced by a development project. They lost their upland rice cultivation which formed part of their diet and had spiritual significance. Many of them used their compensation money unwisely, gambling on cockfights and buying status consumer goods. They were unhappy with the resettlement site and moved away to form new communities in the forest, where they were exposed to malaria.

Source: M. Birley. 1988. Feasibility Test of Guidelines for Forecasting the Vector-borne Disease Implications of Water Resources Development in Two Countries in South-East Asia. World Health Organization Panel of Experts on Environmental Management for Vector Control. Report No.: WHO/VBC/89.3. p. 44. 


\section{Mitigation and Enhancement Measures}

\section{Summary}

- Enhancing benefits and mitigating risks

- The health mitigation and health enhancement hierarchies

- Prevention is better than cure

- Creating multiple barriers in order to safeguard health

- Healthy engineering design

176. Projects generally produce a mixture of health benefits and health risks. They are distributed between different communities. Recommendations identify and enhance the health benefits, mitigate the health risks, and address the needs of communities bearing the brunt of adverse health impacts (Box 20).

177. An example of a health benefit is ensuring that a project optimizes the procurement of local goods and services. This can include purchasing food in local markets and supporting local secondary industries such as haulage, restaurants, and rental accommodation. This raises the socioeconomic status of communities, enabling them to safeguard their own health. A project may also be able to invest in housing, sanitation, drinking water supply, food, public transport, and access to medicines and other social services. Care must be taken, though, to manage price inflation. Increased demand for local food and rental accommodation can cause inflation unless supply is also increased. Inflation excludes communities that are not project beneficiaries leading to under-nutrition and crowding. Mitigation includes social investment to improve supply and careful management of procurement to avoid excessive demand.

\section{Box 20: Activated Sludge Treatment Plant in Syria}

A rapid health impact assessment was undertaken for an activated sludge treatment plant. The output from the plant was destined for irrigation of food crops, with the quality of the output monitored by the plant owners. The output was received by the irrigation department and pumped into irrigation canals. One of the key recommendations of the health impact assessment was that water quality monitoring should be the responsibility of the recipients of the water, not the suppliers. The recipients could then determine the quality of the water and decide to accept or refuse it.

Source: Sustainable Development and Climate Change Department, Asian Development Bank. 
178. An example of mixed health benefits and losses is resettling communities near to the forest edge. The resettled community may benefit from improved housing, water supply and sanitation. However, malaria transmission may be intense in places where vector ecology is linked to forested areas. Resettlement usually requires an environmental assessment during the options stage and an HIA can be added.

179. Another example of mixed benefits and risks arises from promoting pig raising in rice irrigation systems. The pig production provides an economic and hence health benefit. At the same time, the risk of Japanese encephalitis transmission increases and this is a severe communicable disease that has significant economic costs.

\section{A. Mitigation}

180. Mitigation measures are arranged in a hierarchy (Table 40). A similar hierarchy is used for both OHS and CHS. At the top of the hierarchy are actions taken by the project proponent to safeguard the health and safety of the workforce and community through healthy engineering design and social measures. Lower down in the hierarchy are changes in behavior required of the workforce or community as individuals. The dominant principle

\section{Table 40: The Health Mitigation Hierarchy and Two Examples}

\begin{tabular}{|c|c|c|c|}
\hline Hierarchy & How & $\begin{array}{l}\text { Occupational Health and Safety } \\
\text { HIV Example }\end{array}$ & $\begin{array}{l}\text { Community Health and } \\
\text { Safety } \\
\text { Malaria Example }\end{array}$ \\
\hline Avoid & $\begin{array}{l}\text { Design out by } \\
\text { healthy } \\
\text { engineering } \\
\text { design and social } \\
\text { measures }\end{array}$ & $\begin{array}{l}\text { Workers bring families } \\
\text { (seen where worker housing } \\
\text { is unregulated), sexually } \\
\text { transmitted infection control } \\
\text { commitments are included } \\
\text { in construction contracts, } \\
\text { microfinance initiatives } \\
\text { (provide alternatives to } \\
\text { commercial sex work) }\end{array}$ & $\begin{array}{l}\text { Choose localities for } \\
\text { settlements that are more } \\
\text { than } 3 \text { kilometers from } \\
\text { forests and tree plantations }\end{array}$ \\
\hline Abate at site & $\begin{array}{l}\text { Add to design } \\
\text { by healthy } \\
\text { engineering } \\
\text { design and social } \\
\text { measures }\end{array}$ & $\begin{array}{l}\text { Closed construction camps } \\
\text { (seen in oil projects) }\end{array}$ & $\begin{array}{l}\text { Design houses that are } \\
\text { mosquito-proof such as using } \\
\text { insecticide-treated screens }\end{array}$ \\
\hline $\begin{array}{l}\text { Abate at } \\
\text { receptor }\end{array}$ & $\begin{array}{l}\text { Personal } \\
\text { Protection }\end{array}$ & $\begin{array}{l}\text { Condoms and training in their } \\
\text { use }\end{array}$ & $\begin{array}{l}\text { Insecticide-treated nets and } \\
\text { training in their use }\end{array}$ \\
\hline Repair & Medical treatment & Diagnosis and antivirals & $\begin{array}{l}\text { Rapid diagnosis, surveillance, } \\
\text { and effective treatment }\end{array}$ \\
\hline Compensate & $\begin{array}{l}\text { Finance and } \\
\text { insurance }\end{array}$ & $\begin{array}{l}\text { Provide funding to the medical } \\
\text { sector to cope with additional } \\
\text { medical demands during } \\
\text { construction }\end{array}$ & $\begin{array}{l}\text { Provide funding to the } \\
\text { medical sector to cope with } \\
\text { additional medical demands } \\
\text { during construction }\end{array}$ \\
\hline
\end{tabular}

Source: Sustainable Development and Climate Change Department, Asian Development Bank. 


\section{Box 21: Unsustainable Mitigation}

When project proponents construct health clinics or hospitals, they should consider long-term sustainability. Project proponents sometimes build, staff, and operate health clinics for projectaffected communities. After the project is finished and under operation, the clinics are often handed over to the ministry of health. Project evaluations sometimes observe that medical staff can no longer be recruited or retained, especially for clinics in remote rural areas. There are many possible reasons. For example: staff may no longer be paid regularly; medical supplies may not be replenished adequately; staff may have no means of transport; supervision, promotion and encouragement may be lacking; clinic water supplies, sanitation and hazardous waste disposal may be poor; housing and educational facilities for staff may be inadequate; the ministry of health may simply lack the resources to maintain the clinic.

Source: Sustainable Development and Climate Change Department, Asian Development Bank.

is that people should not be required to change their behavior until all higher measures in the hierarchy have been implemented. At the bottom are the consequences of a failure to safeguard. These often include medical treatment. This cost of treatment may be transferred from the project to the health sector. The health sector should be forewarned that this may occur so that it can work with the project to plan for any additional medical services that may be required. Whatever mitigation measures are chosen should be sustainable (Box 21).

\section{B. Enhancement}

181. Enhancement is about maximizing the health benefits of the project and identifying opportunities for improving the health of affected communities (Box 22 and Box 23). For example:

(i) using social investment to further improve the quality of life of affected communities or to support existing plans and programs by the public sector,

(ii) providing vocational training to increase the employability of local workers,

(iii) improving access to social services,

(iv) promoting secondary industry,

(v) improving safe water supplies and waste disposal, and

(vi) improving housing infrastructure (construction camps can be handed over to community housing services when construction is complete).

182. There is no universal health benefit hierarchy equivalent to the mitigation hierarchy. A suggested hierarchy follows. ${ }^{86}$

\footnotetext{
${ }^{86}$ S. Vohra. 2016. Personal observation.
} 
Table 41: The Health Benefit Hierarchy with Examples

\begin{tabular}{|c|c|}
\hline Hierarchy & Examples \\
\hline $\begin{array}{l}\text { Permanent } \\
\text { modifications }\end{array}$ & $\begin{array}{l}\text { - Benefits that last the length of the project, such as roads with space for } \\
\text { nonmotorized users, } \\
\text { - Parks and recreational facilities included in urban housing projects, } \\
\text { - Hydraulic structures that are mosquito-breeding proof. }\end{array}$ \\
\hline Enhancing equity & $\begin{array}{l}\text { - Ensuring that disadvantaged groups benefit, such as protecting and } \\
\text { widening livelihoods, } \\
\text { - Creating healthy choices, such as making the public realm attractive to users. }\end{array}$ \\
\hline Repeated actions & - Maintenance and repair of project structures. \\
\hline $\begin{array}{l}\text { Promoting healthy } \\
\text { behavior }\end{array}$ & $\begin{array}{l}\text { - Targeted health promotion campaigns, such as healthy eating, physical } \\
\text { activity, and protected sex. }\end{array}$ \\
\hline $\begin{array}{l}\text { Enhancing medical } \\
\text { care }\end{array}$ & $\begin{array}{l}\text { - Sustainable improvements to public clinics, that continue to function when } \\
\text { project-related finance is removed. }\end{array}$ \\
\hline
\end{tabular}

Source: Sustainable Development and Climate Change Department, Asian Development Bank.

\section{Box 22: A Health Impact Assessment of Social Housing Redevelopment in England}

A large block of social housing was planned to be redeveloped by its owners, a social enterprise. The redevelopment included substantial modernization of kitchens, bathrooms, windows, and heating. It would be very disruptive to the occupants and some would need temporary rehousing.

An analysis of the affected community indicated that at least $25 \%$ had chronic physical or mental illnesses, or learning disabilities. Some had chaotic lifestyles and addictions. A substantial percentage were members of ethnic minorities.

One key finding from the health impact assessment came from observing that there were two unconnected databases. One database belonged to the owners and registered property location, size and condition, and leaseholder. The other database belonged to social services and identified vulnerable people and the nature of their special needs. Data protection laws prevented the two databases being merged. The challenge was to plan renovation of the properties while taking adequate account of the special needs of occupants. The health impact assessment recommended that social services and social housing collaborate to resolve this.

Source: M. Birley, A. Pennington, and H. Dreaves. 2010. Strategic Guidance for Safeguarding and Improving the Health of Communities Affected by Estate Regeneration in Tower Hamlets. 


\section{Box 23: Control of Dengue Vectors in Viet Nam by Repeated Actions}

In Viet Nam, dengue vector mosquitoes often breed in large outdoor concrete tanks and wells. These permanent breeding sites were controlled by repeated introductions of a local invertebrate predator called Mesocyclops, with the help of the community This was supplemented by waste management programs that repeatedly removed small, temporary breeding sites such as old tires. By these means the mosquito population was reduced by up to $98 \%$ and dengue cases were reduced $77 \%$ compared with other communities.

Sources: B. Kay et al. 2002. Aedes Vectors of Dengue in Three Provinces of Vietnam by Use of Mesocyclops (Copepoda) and Community-based Methods Validated by Entomologic, Clinical, and Serological Surveillance.. Am J Trop Med Hyg. 66 (1). pp. 40-8.; and S. Vu et al. 2005. Elimination of Dengue by Community Programs using Mesocyclops(Copepoda) Against Aedes Aegypti in Central Vietnam. Am J Trop Med Hyg. 72 (1): pp. 67-73.

\section{Multiple Barriers}

183. A key principle for reducing risk is to put multiple barriers in place to prevent exposure to a hazard. This ensures that if any single barrier fails, the whole risk reduction process does not fail. A barrier, in this context, need not be physical. A similar concept is found in food safety where the barriers are called Hazard Analysis Critical Control Points (HACCP), and in water safety planning. For example, multiple barriers for malaria control include:

(i) Environmental engineering measures,

(ii) Water management practices,

(iii) Settlement location,

(iv) Housing improvement,

(v) Distribution of livestock in relation to human settlements,

(vi) Provision of insecticide-treated nets,

(vii) Rapid diagnosis and effective treatment, and

(viii) Poverty reduction and gender empowerment (enables people to protect themselves and their families).

\section{Healthy Engineering Design}

184. The engineering design process is central to any large infrastructure project. It is methodical, highly iterative, and team-based. It includes conceptualization, feasibility assessment, establishing design requirements, outline design, preliminary design, detailed design, and execution planning. During this process the benefits, constraints, and costs of a wide range of options are reduced to a deliverable and detailed final design. It generally includes a high-level risk register or equivalent that is refined at each iteration. 
Figure 11: A Healthy and Sustainable Engineering Design Procedure

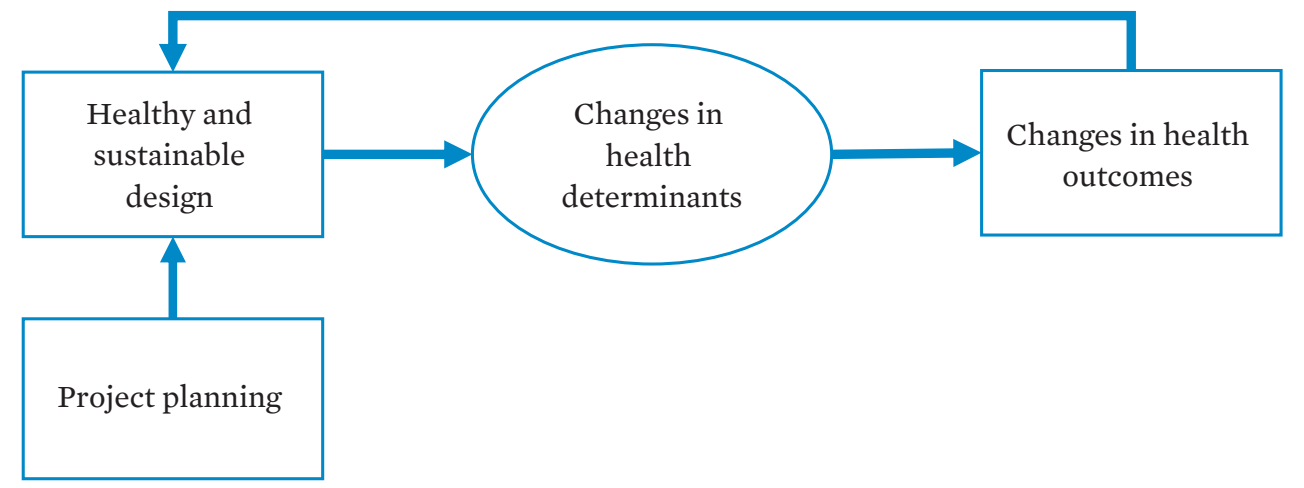

Source: Sustainable Development and Climate Change Department, Asian Development Bank.

185. Figure 11 is a model of a healthy engineering design procedure for delivering projects that enhance CHS. It starts with an intention to have a healthy and sustainable engineering design. The HIA identifies changes in health determinants and outcomes, providing an opportunity to identify gaps, risks and benefits, and make recommendations. Recommendations are fed back into the engineering design through successive iterations.

186. The risk of catastrophic failure is always considered during engineering design. This includes failures of dam walls, explosions and fires, and the consequences of extreme weather events such as landslides and floods. In some cases, HIA may provide strategic recommendations associated with catastrophic failure, such as the development of an emergency and contingency plan, in partnership with public agencies and local community representatives.

187. One approach to healthy engineering design is to provide engineers with detailed design checklists. Detailed checklists have been developed for urban planning, ${ }^{87}$ highways, ${ }^{88}$ and water resource development (footnote 24). Table 42 provides examples of key healthy design considerations in different sectors or themes.

${ }^{87}$ Healthy Urban Development Unit. 2015. Healthy Urban Planning Checklist, second edition.
${ }^{88}$ Health Scotland. 2007. Health Impact Assessment of Transport Initiatives: A Guide. 


\section{Table 42: Examples of Healthy Engineering Design Considerations}

\begin{tabular}{|c|c|}
\hline Sector or Theme & Examples \\
\hline \multirow[t]{3}{*}{$\begin{array}{l}\text { Healthy urban } \\
\text { design }\end{array}$} & $\begin{array}{l}\text { Healthy urban spaces promote active travel and social interaction. This includes walking, } \\
\text { cycling, and using public transport. The public realm is attractive, traffic free, well-lit and } \\
\text { much used. Cycleways are segregated from motorized vehicles. There are signposts with } \\
\text { walking maps and distances are clearly indicated. There are hire bike schemes. Public } \\
\text { transport is affordable and accessible to all. Communities are integrated and cohesive }\end{array}$ \\
\hline & $\begin{array}{l}\text { Markets are healthy with washing and waste disposal facilities. Buildings are designed to } \\
\text { regulate internal temperatures, be accessible to all users, and be vector-proof. }\end{array}$ \\
\hline & Water supply and drainage is designed to prevent vector breeding. \\
\hline $\begin{array}{l}\text { Healthy surface } \\
\text { transport design }\end{array}$ & $\begin{array}{l}\text { Healthy and sustainable surface road transport encourages nonmotorized users. In rural } \\
\text { areas, there are aprons beside the tarmac, or white lines that designate tarmac edges for } \\
\text { nonmotorized users. In urban areas, there are many safe crossing places, walkways, and } \\
\text { passive speed regulators. Intermodal transfer is facilitated and there is safe cycle storage. }\end{array}$ \\
\hline $\begin{array}{l}\text { Healthy energy } \\
\text { projects }\end{array}$ & $\begin{array}{l}\text { Healthy energy projects consult communities about location and have zero emissions } \\
\text { of carbon as gas or particulates. They distribute benefits to disadvantaged communities. } \\
\text { Transmission lines and substations are located away from residential areas where } \\
\text { possible, or buried. }\end{array}$ \\
\hline $\begin{array}{l}\text { Healthy water } \\
\text { supply and } \\
\text { sanitation }\end{array}$ & $\begin{array}{l}\text { Healthy urban water supply systems aim for } 24 / 7 \text { reliability so users are not encouraged to } \\
\text { apply pumps that create negative pressure (and risk of contamination) in the distribution } \\
\text { system, or to store drinking water in ways that can lead to disease vector breeding. } \\
\text { They ensure that appropriate wastewater disposal is provided, preferably in a grid with } \\
\text { decentralized treatment plants. Wastewater contaminated with organic material is a } \\
\text { breeding site for the mosquito vector of urban filariasis. Where septic tanks are used, } \\
\text { healthy design includes seals and netted vents. Where pit latrines are needed, these are } \\
\text { ventilated and use light and shade to deter mosquito breeding. }\end{array}$ \\
\hline \multirow[t]{2}{*}{$\begin{array}{l}\text { Healthy reservoir } \\
\text { design }\end{array}$} & $\begin{array}{l}\text { The engineering design of a dam provides an opportunity to minimize mosquito (vector) } \\
\text { breeding sites. This should be setting-specific, because there are many different mosquito } \\
\text { species, each with their own ecological requirements. Shallow shore lines are avoided. }\end{array}$ \\
\hline & $\begin{array}{l}\text { In some valleys, dams are designed to create cascading reservoirs-this allows rapid } \\
\text { drawdown of individual reservoirs, stranding and killing larvae of the local malaria } \\
\text { mosquito, breeding in the shallow shore waters of reservoirs. However, dam cascades may } \\
\text { change the hydrology of the river, creating rock pools that serve as new breeding places. }\end{array}$ \\
\hline \multirow{5}{*}{$\begin{array}{l}\text { Healthy } \\
\text { agricultural } \\
\text { production } \\
\text { systems }\end{array}$} & $\begin{array}{l}\text { The engineering design of agricultural systems provides many opportunities to promote } \\
\text { a healthy environment. }\end{array}$ \\
\hline & $\begin{array}{l}\text { Agricultural systems often require the safe collection and channeling of water for } \\
\text { irrigation, the flooding of rice fields, and the disposal of wastewater contaminated with } \\
\text { fertilizers and pesticides. A range of disease vectors may breed in the waters and their } \\
\text { numbers can be reduced by careful design, operation, and maintenance. Water is also } \\
\text { required for bathing, washing and drinking by farmer and laborer families. Competition } \\
\text { for water between domestic, agricultural and industrial users can be designed out. }\end{array}$ \\
\hline & $\begin{array}{l}\text { Pesticides should be stored in properly designed sheds and applied using appropriately } \\
\text { designed personal protection equipment. }\end{array}$ \\
\hline & $\begin{array}{l}\text { Commercial farmers require land allocated for traditional subsistence crops and } \\
\text { accessible markets for their produce. }\end{array}$ \\
\hline & Tree plantations can be designed to minimize vector breeding. \\
\hline Health facilities & $\begin{array}{l}\text { Hospitals, clinics, and health care centers must have water, sanitation, and hygiene } \\
\text { facilities; infrastructure must facilitate effective and safe medical waste management. }\end{array}$ \\
\hline
\end{tabular}

Source: Sustainable Development and Climate Change Department, Asian Development Bank. 


\section{Appraisal}

188. Appraisal is a critical component of HIA as it assures quality (Box 24). It should be undertaken by a highly competent HIA specialist. Appraisals may be made by both ADB and the national government. In the case of national governments, the ministry of health is either represented on a national EIA committee convened by the environment authorities or has its own HIA unit mandated with this responsibility. The competencies required include awareness, knowledge and experience in HIA and a background in one or more health-related disciplines such as public or environmental health (Box 25). The competency level recommended is 3-4 (Section IVB.4). As illustration, the ministry of health staff or consultant responsible for appraising the HIA of a large, category A, project should have Level 4 competency. Detailed guidance on how to review HIA report is in Appendix 5.

189. The appraisal of the HIA report should consider:

(i) Whether the TOR were adequate, and whether the TOR were adhered to by the consultants;

(ii) Whether the report requires major or minor revision;

(iii) Conflicts of interest;

(iv) Timing;

(v) Budgeting;

(vi) Consultants' competence;

(vii) Access to information, such as government datasets;

(viii) Procedural rigor;

(ix) Accuracy and comprehensiveness;

(x) Justification for recommendations;

(xi) Sources of potential bias;

(xii) Whether any health impacts have been obviously missed.

\section{Box 24: Health Impact Assessment of a Suburban Housing and Bypass Project in England}

The project included a new housing estate and bypass road on the edge of a market town. The health impact assessment report noted that the planned bypass did not make adequate provision for crossings of footpaths and minor roads and this would create barriers. The design of the housing estate assumed that the main mode of transport would be private car. The health impact assessment identified the gap and proposed making adequate provision for active travel (cycle and walkways, safe and accessible crossing points, and bus stops).

Source: Sustainable Development and Climate Change Department, Asian Development Bank. 


\section{Box 25: Procurement of Services}

The curriculum vitae of the lead health impact assessment (HIA) consultant provides good evidence of their training and experience and the HIA may be biased accordingly. The following three scenarios are based on personal observation of HIAs and the curriculum vitae of those who wrote them. Each consultant has significant weaknesses.

(i) The consultant has training and experience in environmental assessment and is a competence generalist. Experience of public health

(ii) is limited to environmental health issues such as pollution control. The consultant has not attended an HIA training course and has no training in a health discipline. The HIA report is strong on pollution control but weak on everything else. Most of the detailed recommendations concern improved pollution monitoring.

(iii) The consultant has training in medicine and has research experience in the treatment and control of one parasitic disease, such as malaria. The consultant has not attended an HIA training course and does not have a master's degree in public health. The HIA report is strong on the research experience but weak on everything else. Most of the detailed recommendations concern strengthening of medical services.

(iv) The consultant has a master's degree in public health and extensive experience of health promotion. The consultant has not attended an HIA training course and has no experience of infrastructure development projects. The HIA report is a detailed health needs assessment of the existing community.

Source: Sustainable Development and Climate Change Department, Asian Development Bank.

190. The appraisal is carried out in three ordered steps.

(i) Appraisal of the HIA process (TOR strictly followed, objectivity, conflict of interest, timing, budgeting, access to information and procedural rigor);

(ii) Appraisal of the HIA content (identification of relevant environment and socioeconomic determinants, consideration of risks and opportunities for vulnerable groups, the integration of findings into an overall HIA, justification and evidence base for the conclusions) (Box 26); and

(iii) Appraisal of the public health management plan (economic feasibility, social acceptability, and technical soundness of proposed measures, sensitivity analysis, institutional arrangements required for its implementation, and monitoring components). 


\section{Box 26: Appraisal of the Health Component of the Social Assessment and Social Management and Monitoring Plan of Don Sahong Hydropower Project, Lao People's Democratic Republic}

The social assessment identified four communicable diseases that were present in the project area and made broad and nonspecific recommendations for their control during the construction phase. The diseases were dengue fever, schistosomiasis, opisthorchiasis and sexually transmitted infections (STIs). For three of the diseases, there was no indication of how the project could change the risk of infection.

Recommendation (Exact Text)

Control of breeding Aedes aegypti (vector for dengue fevers) by elimination of small standing pools that provide breeding habitat.

Education and treatment programs for Schistosoma mekongi by: (i) drug treatments for local communities and workers; (ii) education in risks of direct contact (e.g. bathing) in the river water; (iii) provision of suitable ablution and sanitary facilities to limit the risk of S. mekongi infection back to the intermediate host a small river snail.

Educate and regularly test and treat workers and residents for infection by liver fluke (e.g., Opisthorchis viverrini). Use public awareness programs to discourage eating local raw fish dishes likely to be contaminated with these parasites.

Provide an active program promoting community and worker awareness and treatment of STI and HIV infections. While the existing rates of these infections are low, transient worker populations may introduce these diseases (The Government of Lao People's Democratic Republic actively encourages such prevention and control programs).

\section{Appraisal}

No indication of how the project could change the risk of dengue or how breeding sites could be controlled.

No indication of how the project could change the risk of schistosomiasis, how communities might stop bathing in rivers, or what is a suitable ablution and sanitary facility.

No indication of how project could change the risk of opisthorchiasis. Reinfection can be prevented by avoiding eating raw fish.

There was an indication of how the project might change the risk of STIs. No indication of what an awareness and treatment might include.

The health baseline noted the high level of undernutrition in the project affected communities and the importance of fish in local diets and economy. The health impacts on nutrition associated with loss of fisheries were not discussed. However, the need to safeguard fisheries was noted and general mitigation measures were proposed.

The social assessment concluded that "With these mitigating measures in place, including implementation of the Social Management and Monitoring Plan (SMMP) which provides for new health facilities, impacts on public health will not be significant, and positive impacts are likely".

The SMMP report contained no references to dengue, opisthorchiasis, or how they should be managed and monitored. There was a brief mention of schistosomiasis, but no mitigation measures. There was a brief discussion of STIs (STDs) but it only proposed an awareness program.

There was a section entitled 'health promotion' that included: existing health infrastructure and medical care, emergency response, camp management, safety due to rock blasting, road traffic management, education promotion program, agricultural promotion program, public awareness program, livelihood training and awareness raising, construction of infrastructure, livelihood development, and employment and commercial opportunities.

The following health indicators were proposed for the monitoring program: availability of and distance to safe drinking water and sanitation; incidence of main diseases, gender, age; death rates of main diseases, gender, age; trained health staff; percentage of catchment population; distance to health center; child nutrition such as height for age (stunting), weight for age (wasting); possibly incidence of HIV and AIDS and other STDs by gender and age; household economy including: housing, quality of roof, walls, floor, road to next village, tracks, dust/motor road. There was no mention of how morbidity and mortality rates could be determined.

In general, the health recommendations focus on medical care and changing community behavior.

Source: National Consulting Company Vientiane. 2013. Don Sahong Hydropower Project, Lao PDR: Social Management and Monitoring Plan. 


\section{Public Health Management Plan}

\section{Summary}

- The most important part of an HIA

- Consists of actions and monitoring plans that must be justified, negotiated, and implemented

- What to monitor

- The use of health indicators

191. The public health management plan (PHMP) may be drafted with the HIA report. It is finalized after the HIA report, together with its recommendations, have been appraised and accepted. It is the most important part of the HIA because it leads to real changes in the project proposal that enhance health benefits and reduce health risks for vulnerable communities (Box 27). The recommended level of competency of the consultants who draft it is level 3-4. The PHMP requires approval and appraisal before negotiations can start about the resources to implement it. As a result of these negotiations, some components may need to be suppressed. The extent to which the PHMP budget will be part of the project loan will need to be negotiated with the client country. Other bilateral or multilateral sources of external support (technical assistance) may also need to be identified to help deliver the PHMP. The PHMP has two main components: the actions agreed, and the monitoring plan.

\section{A. Actions Agreed}

192. The PHMP identifies who does what and by when (Table 43). The key points to consider are as follows.

(i) The plan focuses, as far as practical, on the changes in health attributable to the project, rather than the general health needs of the community. The general health needs of the community are managed through the normal ministry of health and local government budgets, which may need strengthening independently.

(ii) Mitigation and enhancement measures follow the hierarchy described in section XI, and create multiple barriers.

(iii) Cost-benefit analysis may not be practical, but is desirable when other sectors need to be convinced of their obligations to participate in the plan's implementation.

(iv) The plan is practical, specific, achievable, acceptable, and affordable by the project owner.

(v) Adaptive management will be required through appropriate monitoring. 


\section{Box 27: Public Health Action Plan of Nam Theun 2 Hydropower Project}

The Nam Theun 2 Hydropower Project in the Lao People's Democratic Republic (Lao PDR) underwent a rapid (3-week) HIA, just prior to the start of construction. Based on the HIA, a public health action plan (PHAP) was formulated. The PHAP is 157 pages long. The plan covered 8 years and had three components: resettlement health program, regional health program, and monitoring and surveillance of health. A health program management unit was created to assure planning, coordination, management and supervision. Implementation was assured by Lao PDR public health institutions. The PHAP included a schedule and a budget. The plan was developed by a taskforce of the Lao PDR Ministry of Health with technical support from public health consultants and an environmental health specialist. Though limited by time constraints, community and stakeholder consultation was part of the HIA. The timing of the HIA explains the PHAP's focus on health sector/medical interventions-it was too late for project design and management measures. Financing was provided by several different development institutions.

There were many technical components of the PHAP including:

- Improving medical care services;

- Providing health education activities to sensitize the local communities on the changing health risks;

- An infectious disease detection system with outbreak preparedness, as an influx was expected of 4,000 workers and 8,000-16,000 camp followers and service providers;

- Construction of sanitary facilities, waste management and domestic water supply for the camp followers;

- $\quad$ Assurance of domestic water quality and quantity;

- Reproductive health services including condom distribution, safe motherhood, family planning, and health promotion;

- $\quad$ Support for financial accessibility to medical services; and

- Specification of entitlements to compensation, rehabilitation and access to preventive measures.

One subcomponent of the infectious disease program concerned vector-borne diseases. This included:

- Promotion and prevention through health education, dengue breeding site control, distribution of long-lasting impregnated mosquito nets, development and implementation of waste management plans;

- Diagnosis and detection of malaria using antigen test and/or microscopy;

- Appropriate treatment of malaria, taking account of drug resistance;

- Adequate supportive care of dengue and other fevers;

- Capacity building, including health promotion skills; and

- Monitoring and surveillance, including quality control.

Source: Nam Theun 2 Power Company. Nam Theun Report Documents. 
Table 43: Example of Simple Public Health Management Plan Components

\begin{tabular}{lllll} 
Action Agreed & \multicolumn{1}{c}{$\begin{array}{c}\text { Who is } \\
\text { Responsible }\end{array}$} & $\begin{array}{l}\text { When It Must be } \\
\text { Implemented }\end{array}$ & $\begin{array}{l}\text { How It is } \\
\text { Implemented }\end{array}$ & $\begin{array}{l}\text { How Implementation } \\
\text { Will Be Monitored }\end{array}$ \\
\hline $\begin{array}{l}\text { Ensure that all } \\
\text { construction workers } \\
\text { have access to condoms }\end{array}$ & $\begin{array}{l}\text { Construction } \\
\text { contractor }\end{array}$ & $\begin{array}{l}\text { Before } \\
\text { construction } \\
\text { workers arrive on } \\
\text { site }\end{array}$ & $\begin{array}{l}\text { Add clause to } \\
\text { construction } \\
\text { contract }\end{array}$ & $\begin{array}{l}\text { Number of condoms } \\
\text { supplied }\end{array}$ \\
\hline $\begin{array}{l}\text { Safe crossing points on } \\
\text { highways }\end{array}$ & $\begin{array}{l}\text { Engineering } \\
\text { designers }\end{array}$ & $\begin{array}{l}\text { During the } \\
\text { engineering } \\
\text { design process }\end{array}$ & $\begin{array}{l}\text { Bridges, } \\
\text { tunnels, traffic } \\
\text { lights }\end{array}$ & $\begin{array}{l}\text { Direct observation } \\
\text { of crossing points } \\
\text { constructed }\end{array}$ \\
\hline $\begin{array}{l}\text { Providing resettlement } \\
\text { community with } \\
\text { insecticide-treated nets }\end{array}$ & $\begin{array}{l}\text { Resettlement } \\
\text { site health } \\
\text { center }\end{array}$ & $\begin{array}{l}\text { As resettlement } \\
\text { community are } \\
\text { given houses }\end{array}$ & $\begin{array}{l}\text { Purchase and } \\
\text { distribution of } \\
\text { nets }\end{array}$ & $\begin{array}{l}\text { Number of nets } \\
\text { distributed, } \\
\text { household survey }\end{array}$ \\
\hline
\end{tabular}

Source: Sustainable Development and Climate Change Department, Asian Development Bank.

\section{B. Monitoring Plan}

193. The health outcomes of a project will often deviate from the assessment. A monitoring plan is required that detects deviations at an early stage and provides decision makers with sufficient information to manage them in a timely manner. There are different types of monitoring including:

(i) Compliance monitoring of the PHMP, in accordance with agreed roles and responsibilities;

(ii) Health outcome monitoring, such as changing disease rates; and

(iii) Health determinant monitoring using indicators associated with potential changes in health outcomes.

194. Table 44 provides examples of each and is based on a table in the Poverty and Social Analysis Handbook (footnote 31). Compliance monitoring is concerned with the implementation of PHMPs and is an administrative arrangement. It is basically a check to see whether the non-health sector partners comply with their obligations for the implementation of the PHMP. Health outcome monitoring depends on having accurate and up-to-date records of changes in disease rates in project affected communities. This is often difficult and costly to obtain. Standard health sector records are usually not suitable. Some disease rates change quickly, such as malaria rates and acute poisoning, while others change slowly over decades, such as cancer rates. The preferred technical option is to monitor health indicators based on health determinants. Indicators are also monitored to demonstrate a positive or negative change in community health attributable to a project for project evaluation purposes.

\section{Health Indicators}

195. Good health indicators are easy to monitor and respond rapidly to change. If they are identified during the baseline study, then the changes associated with the project may be observable. As they are based on determinants rather than health outcomes, they may not be obviously health-related. Many of the indicators used in environmental and social assessment 
Table 44: Example of Types of Health Monitoring

\begin{tabular}{|c|c|c|c|c|}
\hline Type & $\begin{array}{c}\text { Examples of Monitoring } \\
\text { Achievements }\end{array}$ & $\begin{array}{c}\text { Example of What to } \\
\text { Monitor }\end{array}$ & Achievable & $\begin{array}{c}\text { Attributable } \\
\text { to the } \\
\text { Project }\end{array}$ \\
\hline Compliance & $\begin{array}{l}\text { At least one action in the } \\
\text { public health management } \\
\text { plan has been implemented } \\
\text { for each of the construction } \\
\text { and operational stages and } \\
\text { is functioning as intended } \\
\text { at the time of monitoring. }\end{array}$ & $\begin{array}{l}\text { A map is available } \\
\text { showing the time and } \\
\text { location of all serious } \\
\text { traffic injuries on the } \\
\text { access roads }\end{array}$ & $\begin{array}{l}\text { Relatively } \\
\text { easy and } \\
\text { non- } \\
\text { technical }\end{array}$ & $\begin{array}{l}\text { Relatively } \\
\text { easy }\end{array}$ \\
\hline Outcome & $\begin{array}{l}\text { After the first year of } \\
\text { operation, at least one } \\
\text { disease prevalence rate has } \\
\text { improved or stabilized and } \\
\text { there is monitoring data or } \\
\text { stakeholder consensus that } \\
\text { this is attributable to the } \\
\text { project. }\end{array}$ & $\begin{array}{l}\text { The recorded number } \\
\text { of cases of malaria at } \\
\text { the local clinic has } \\
\text { decreased (does not take } \\
\text { account of population } \\
\text { size, clinic access, } \\
\text { health care seeking } \\
\text { behavior, diagnostic } \\
\text { accuracy) }\end{array}$ & $\begin{array}{l}\text { Difficult, or } \\
\text { impossible }\end{array}$ & $\begin{array}{l}\text { Difficult, or } \\
\text { impossible }\end{array}$ \\
\hline Indicator & $\begin{array}{l}\text { At least one health } \\
\text { indicator has improved } \\
\text { by the beginning of the } \\
\text { operational phase. }\end{array}$ & $\begin{array}{l}\text { See examples below } \\
\text { (main text, para. 195) }\end{array}$ & $\begin{array}{l}\text { Relatively } \\
\text { easy }\end{array}$ & $\begin{array}{l}\text { Relatively } \\
\text { easy }\end{array}$ \\
\hline
\end{tabular}

Source: Sustainable Development and Climate Change Department, Asian Development Bank.

are in this category (Box 28). Examples of health indicators that are relatively easy to monitor include the following:

(i) Volume of water supplied through water meters;

(ii) Number of mosquito nets in use;

(iii) Price of basic foods and rental accommodation;

(iv) Number of condoms supplied;

(v) Insecticide storage practices;

(vi) Road traffic accidents reported;

(vii) Drug supplies in health centers;

(viii) Air and water pollution levels measured by environmental assessors;

(ix) Growth of informal settlements;

(x) Increase in bars, brothels, and sex shows;

(xi) Height and weight measurements of children taken in government clinics or schools;

(xii) Project complaint records;

(xiii) Police reports of crimes and fines;

(xiv) Injury and illness rate;

(xv) Number of construction site inspections conducted;

(xvi) Number of employees trained in OHS.

196. A complete list of health indicators for use in ADB in each sector has not yet been developed and tested. The following are illustrative. 
Table 45: Examples of Health Indicators by Sector

\begin{tabular}{|c|c|}
\hline Sector & Typical Indicators \\
\hline Water supply & Volume of water supplied through water meters \\
\hline Sanitation & Change in nuisance mosquito densities \\
\hline $\begin{array}{l}\text { Urban } \\
\text { development }\end{array}$ & Outdoor air quality, crime rates, public transport volumes \\
\hline Energy & Number of households replacing biomass cookers with electric cookers \\
\hline Transport & Road traffic accidents reported \\
\hline $\begin{array}{l}\text { Construction } \\
\text { generally }\end{array}$ & $\begin{array}{l}\text { Number of condoms supplied, price of basic foods and rental accommodation, } \\
\text { growth of informal settlements, increase in bars and sex shows, number of worker- } \\
\text { hours worked without an accident. }\end{array}$ \\
\hline Agriculture & Insecticide storage practices \\
\hline
\end{tabular}

Source: Sustainable Development and Climate Change Department, Asian Development Bank.

\section{Box 28: Health Indicators Proposed for the Mandalay Urban Services Improvement Project}

The Mandalay Urban Services Improvement Project includes components on water supply, sanitation, waste management and flood management with both structural and nonstructural interventions. The HIA identified the following health indicators, building from and complementing the indicators proposed under the design and monitoring framework.

- $\quad$ Reported incidence of water-borne diseases (diarrhea) and incidence of vector-borne diseases (dengue, lymphatic filariasis, and possibly malaria), by township or wards based on Ministry of Health statistics and household surveys.

- Percentage of households with access to piped water on premises in applicable townships, based on household surveys or water provider data.

- $\quad$ Percentage of households with 24/7 water supply based on household surveys or water provider data.

- Percentage of households with unsafe drinking water storage practices, and using unsafe water storage containers, based on household surveys.

- Water quality at the household tap based on water quality sampling.

- Number and percentage of households with flush or pour-flush toilets connected to sewer systems including breakdown by gender and age of head of household, number of household members, and household income based on household surveys.

- Number and percentage of households in flood-prone areas based on annual local government reporting of flooding and ongoing flood risk monitoring.

- The indicators focused on both health outcomes and health determinants that are affected by the project.

Source: ADB. 2005. Mandalay Urban Services Improvement Project (MUSIP). Manila. 


\section{Implementation}

197. This sourcebook has explained what health is, how infrastructure projects can affect health, how both positive and negative health impacts can be assessed, and the opportunities for health enhancement and health safeguarding. But this is only the beginning of the story.

198. The next step is embedding practical procedures for routine HIA in both the operations of the ADB and the DMCs through a common understanding. In some cases, there may still be a double bind in loan and grant agreements. Borrower countries may be unsure whether they can request from $\mathrm{ADB}$ the financial resources to undertake an HIA. ADB, and other lenders, may be unsure whether they can request a lender country to undertake an HIA.

199. Many DMCs have adopted, or are adopting, policy or legislation about HIA. ADB is assisting countries to develop or revise their own national and provincial HIA guidelines, through the Results for Malaria Elimination and Communicable Diseases Threats in Asia and Pacific technical assistance program. In addition, ADB is financing demonstration projects in countries by adding HIA to projects which might not otherwise include one. Universities in the region are developing curricula for teaching HIA, with assistance from ADB. These will provide the new generation of trained consultants with the skills to undertake all the steps required in an HIA. All of this will assist in promoting a consensus.

200. The practical procedures needed in each ministry, country, or division, cannot be prescribed. They must be debated, designed, and owned by the staff in those institutions. This will require structured and engaging workshops. The procedures must be designed from the ground-up by staff who know what works and who feel empowered by senior managers to undertake the task of such organizational change..$^{89}$ One approach is referred to as living systems theory ${ }^{90}$ and is based on the work of Wheatley and Rogers. ${ }^{91}$ Their maxims for organizational change are:

(i) Real change happens in real work;

(ii) Those who do the work do the change;

(iii) People own what they create;

(iv) Start anywhere, follow it everywhere; and

(v) Connect the system to more of itself.

201. With these steps, or something equivalent, HIA will become firmly embedded in development practice and contribute strongly to ADB's goal of ending poverty in the Asia Pacific region.

\footnotetext{
${ }^{89}$ M. Wheatley.1996. The Irresistible Future of Organizing:

${ }^{90}$ Heart of the Art. 2017. Heart of the Art.

${ }^{91}$ M. Kellner-Rogers and M. Wheatley. 1996. A Simpler Way. San Francisco: Berrett-Koehler.
} 


\section{More Information}

\section{A. Books and Guides}

202. A search of the internet will reveal many guides and tutorials on HIA, such as the following.

(i) Asian Development Bank. 2003. A Primer on Health Impacts of Development Programs.

(ii) Birley, M. 2011. Health Impact Assessment, Principles and Practice. This textbook introduces HIA and is a ready source for the standard procedures, methods and tools that are used. It complements this text.

(iii) British Standard for Occupational Health and Safety Management BS OHSAS 18001.

(iv) CHETRE. 2007. Health Impact Assessment: A Practical Guide.

(v) IFC. 2012. Guidance Note 4: Community Health, Safety and Security.

(vi) International Association of Oil and Gas Producers. 2016. Health Impact Assessment.

(vii) International Council on Metals and Mining. 2014. Health Impact Assessment: Summary of the Good Practice Guidance.

(viii) International Finance Corporation. 2016. Introduction to HIA.

(ix) International Finance Corporation. 2012. Guidance Note 2: Labor and Working Conditions.

(x) Quigley, R., den Broeder, L., Furu, P., Bond, A., Cave, B. and Bos, R. 2006. Health Impact Assessment International Best Practice Principles. Special Publication Series Number 5, International Association for Impact Assessment: Fargo USA.

(xi) World Bank Group Environmental, Health, and Safety (EHS) Guidelines.

(xii) World Health Organization, Glossary of Terms Used in Health Impact Assessment.

(xiii) World Health Organization, Health Impact Assessment.

(xiv) WPRO, Thematic Working Group on Health Impact Assessment, in the Regional Forum on Environment and Health in Southeast and East Asian Countries. 


\section{Communicable Diseases in Infrastructure Development, Including Vector-Borne Diseases}

\section{A. Introduction}

1. This appendix explains how communicable diseases can be affected by infrastructure development. It provides knowledge for users to answer questions about communicable diseases in project screening checklists. For example, the Handbook on Poverty and Social Analysis (PSA) ${ }^{1}$ has the following questions.

(i) What other social issues and risks should be considered in the project design?

- Spread of communicable diseases, including HIV and AIDS Indicate high $(\mathrm{H})$, medium (M), low (L).

(ii) How are these additional social issues and risks going to be addressed in the project design? (The question is asked at both the concept and design stage.)

2. This appendix should be read in conjunction with the Asian Development Bank guidance on harmonizing HIV prevention in the infrastructure sector. ${ }^{2}$

3. Health and safety issues encompass all communicable diseases, noncommunicable diseases, injuries, nutritional disorders, mental illness, and well-being that may be changed by a project. These are mediated by the determinants of health.

4. Thus, communicable diseases are only one of a set of health concerns associated with infrastructure development.

\section{B. Communicable Diseases}

5. Communicable or infectious diseases can be acquired from another person or animal. By this means, they can multiply and spread through a population. They have the potential to become epidemics, like severe acute respiratory syndrome (SARS) and to persist. They may persist as continuous or seasonal risks. The pathogens that cause the disease can develop resistance to drugs, so that a previously controlled disease becomes uncontrolled. Noncommunicable diseases, by contrast, are not transmitted from one person to another and drug resistance is less likely.

6. Communicable diseases can be classified by the mode of transmission. The following simplified table, with just a few examples, is illustrative (Table A1.1). There are seven subcategories.

ADB. 2012. Handbook on Poverty and Social Analysis. Manila.

2 ADB. 2010. Practice Guidelines for Harmonizing HIV Prevention Initiatives in the Infrastructure Sector: Greater Mekong Subregion. Manila. 
7. Detailed information about these subcategories and the associated diseases is widely available on the web. From the perspective of infrastructure development, they have the following common features.

(i) A set of health determinants that can be changed by a project.

(ii) The relative importance within a community of communicable and noncommunicable diseases.

(iii) A risk of emergent new diseases and of drug resistance.

(iv) A baseline prevalence rate.

\section{Health Determinants}

8. Health determinants are the factors that change the risk of disease. Table A1.2 illustrates this for communicable diseases. See the definition of health on the main text for a more comprehensive list.

\section{Relative Importance of Communicable Diseases}

9. Communicable disease is one category of health outcomes that can be changed by a project, as the operational definition of health indicated. There are four others, as seen in Table A1.3. All the categories can be important in infrastructure development. A focus on single

Table A1.1: Subcategories of Communicable Diseases

\begin{tabular}{ll}
$\begin{array}{ll}\text { Subcategory } \\
\text { Vector-borne }\end{array}$ & \multicolumn{1}{c}{ Examples } \\
\hline Foodborne & Salmonellosis, Toxoplasmosis \\
Waterborne & Cholera, Amebiasis \\
\hline Fecal-Oral & Hepatitis A, Shigellosis \\
Airborne & Meningitis, Flu \\
\hline Human contact & HIV, Syphilis \\
\hline From animals (zoonoses) & Trichinosis, Cysticercosis \\
\hline
\end{tabular}

Source: Sustainable Development and Climate Change Department, Asian Development Bank.

Table A1.2: Example of Health Determinants for Communicable Diseases

\begin{tabular}{|c|c|c|}
\hline Some Health Determinants & Question to Ask & Notes \\
\hline Physical Environment & Does it favor transmission? & E.g., is a vector present? \\
\hline Community & Is it vulnerable? & $\begin{array}{l}\text { Differentiated by age, gender, location, } \\
\text { socioeconomic status, and heredity }\end{array}$ \\
\hline Medical service & Is it vigilant? & $\begin{array}{l}\text { Does the service have capacity, } \\
\text { capability, and jurisdiction? }\end{array}$ \\
\hline
\end{tabular}

Source: Sustainable Development and Climate Change Department, Asian Development Bank. 
Table A1.3: Examples of Links Between Sectors and Health Outcomes

\begin{tabular}{|c|c|c|c|c|c|}
\hline Sector/Theme & $\begin{array}{c}\text { Communicable } \\
\text { Diseases }\end{array}$ & $\begin{array}{l}\text { Noncommunicable } \\
\text { Diseases }\end{array}$ & Injury & Nutritional & $\begin{array}{l}\text { Mental } \\
\text { Illness and } \\
\text { Well-Being }\end{array}$ \\
\hline Energy & Malaria & Lung diseases & Electrocution & Wasting & $\begin{array}{l}\text { Stress and } \\
\text { Anxiety }\end{array}$ \\
\hline Transport & $\begin{array}{l}\text { Malaria, Sexually } \\
\text { Transmitted } \\
\text { Infections }\end{array}$ & $\begin{array}{l}\text { Cardiovascular } \\
\text { diseases }\end{array}$ & $\begin{array}{l}\text { Road Traffic } \\
\text { Injuries }\end{array}$ & Diabetes & $\begin{array}{l}\text { Stress and } \\
\text { Anxiety, } \\
\text { Isolation }\end{array}$ \\
\hline $\begin{array}{l}\text { Urban } \\
\text { development }\end{array}$ & $\begin{array}{l}\text { Tuberculosis, } \\
\text { Sexually } \\
\text { Transmitted } \\
\text { Infections }\end{array}$ & $\begin{array}{l}\text { Hypertension, } \\
\text { Asthma }\end{array}$ & $\begin{array}{l}\text { Communal } \\
\text { Violence- } \\
\text { Related } \\
\text { Injuries }\end{array}$ & Obesity & $\begin{array}{l}\text { Depression, } \\
\text { Alcoholism, } \\
\text { Suicide }\end{array}$ \\
\hline $\begin{array}{l}\text { Water supply } \\
\text { and sanitation }\end{array}$ & $\begin{array}{l}\text { Cholera, Dengue, } \\
\text { Ascariasis }\end{array}$ & $\begin{array}{l}\text { Arsenicosis and } \\
\text { Fluorosis }\end{array}$ & Drowning & Goiter & Cretinism \\
\hline Agriculture & $\begin{array}{l}\text { Leptospirosis, } \\
\text { Trichinosis, } \\
\text { Japanese } \\
\text { encephalitis }\end{array}$ & $\begin{array}{l}\text { Pesticide } \\
\text { Poisoning }\end{array}$ & $\begin{array}{l}\text { Musculo- } \\
\text { skeletal } \\
\text { Injuries, } \\
\text { Heatstroke }\end{array}$ & $\begin{array}{l}\text { Stunting } \\
\text { and } \\
\text { Wasting }\end{array}$ & $\begin{array}{l}\text { Domestic } \\
\text { Violence }\end{array}$ \\
\hline
\end{tabular}

Source: Sustainable Development and Climate Change Department, Asian Development Bank.

diseases, such as malaria and HIV, or single categories of diseases, such as communicable disease, is not recommended.

10. The relative importance of communicable versus noncommunicable diseases varies with the state of economic development. For example, deaths from communicable diseases are more common in Myanmar than Thailand. The reverse is true for noncommunicable disease (Figure A1.1 and Table A1.4). Some localities, such as the urban fringe, experience an increase in both. As nations develop, there is often, but not always, an epidemiological transition where communicable diseases decline and noncommunicable diseases increase.

\section{E. Risk of Emergence}

11. Infrastructure development can change the risk of emergent infections with epidemic and pandemic potential. ${ }^{3}$ Sometimes these are new infections and sometimes they are drugresistant forms of earlier infections. Seventy-five percent of emerging disease threats arise from animal reservoirs and this has led to a consideration of human and animal diseases together: "One Health."

12. Examples of emergent infections in Asia include:

(i) HSN1 and H7N9 avian influenza;

(ii) SARS (the economic impact of SARS was estimated at $\$ 40$ billion);

3 USAID. 2012. Proposed Supplemental Guidance to the IFC's Introduction to Health Impact Assessments: Emerging Infectious Diseases and HIAs.

4 One Health Initiative. 2016. One World One Medicine One Health. 
Figure A1.1: Comparison of Death Rates from Communicable and Noncommunicable Diseases (excluding Injury and Nutritional Disorders)

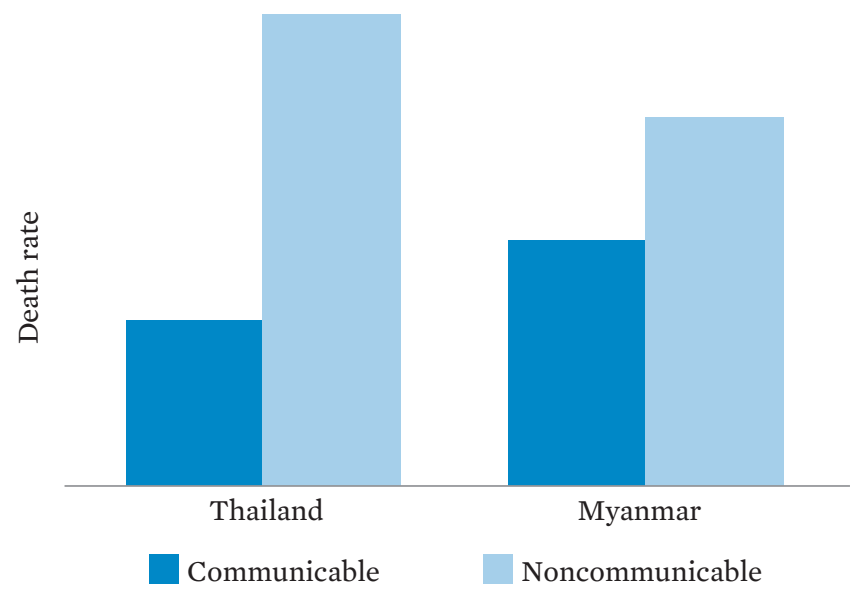

Using available data in 2016.

Source: World Health Organization. Country Profiles.

(iii) Chikungunya, Nipah, and Zika virus; and

(iv) Multiple drug resistant malaria, tuberculosis, and Staphylococcus aureus.

13. Devastating examples elsewhere include the Ebola outbreak in Africa. ${ }^{5}$ In 2015, Ebola cost $15 \%$ of the gross domestic product of the affected countries.

14. The impacts of these epidemics can include:

(i) Weakened health system leading to increased morbidity,

(ii) High mortality among health care workers,

(iii) Food insecurity,

(iv) Lack of education due to school closure,

(v) Commercial closure and increase of unemployment,

(vi) Diminished trust in governments,

(vii) Increase of ethnic divisions and altered cultural norms,

(viii) Further increase in poverty and reduced resilience, and

(ix) Stigma.

15. The lessons from these epidemics are:

(i) Health and veterinary systems must be strengthened together, which is challenging.

(ii) Risk management must be multisectoral and participative. This may include private companies contributing financially and through their core competencies.

5 UNDP. 2016. Socio-Economic Impact of the Ebola Virus Disease in West African Countries; United Nations Economic Commission for Africa. 2016. UNECA Releases Report on Ebola Socio-Economic Impact. 
(iii) Management of risks starts with project design and requires a comprehensive impact assessment.

(iv) There is a continuum from prevention, to preparedness, to response and to restoration.

16. Emergent diseases are often associated with changing land use, especially in rural areas, and the animal-human-ecosystem interface (Figure A1.2). Events are increasing in frequency and impact around the globe. The potential impact has been rated higher than weapons of mass destruction, interstate conflict, and failure of climate change adaptation. ${ }^{6}$ Levels of preparedness vary between countries and are not optimal.

17. An international framework agreement supports the development of mitigation measures. ${ }^{7}$

\section{F. Distinguishing Baseline Risks and Project-Related Risks}

18. The health baseline indicates the risk of communicable diseases independently from the project. The risk is measured by the reported case incidence rate. This is the number of people who are diagnosed as having the disease divided by the number of people attending a health clinic. The reports from health clinics are aggregated by district, province,

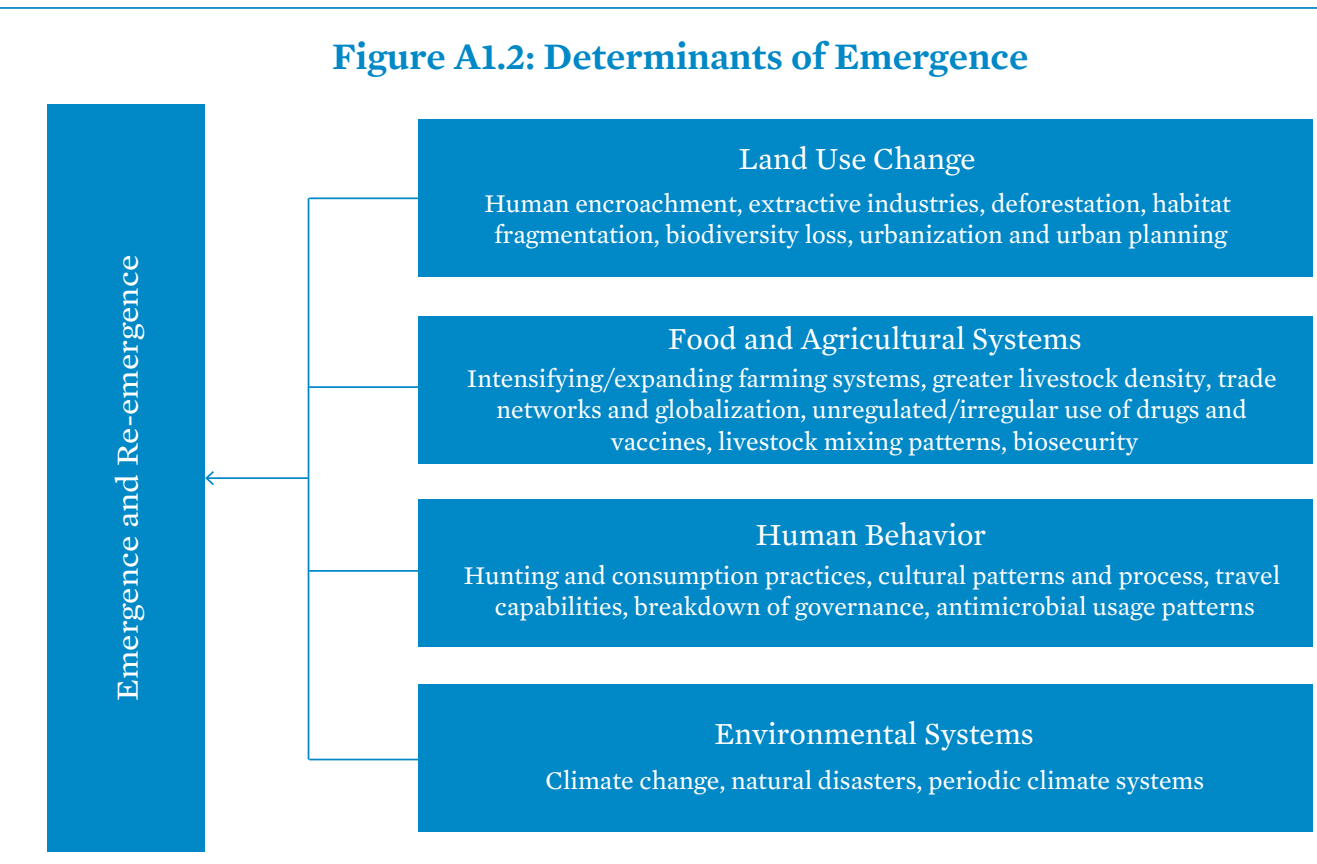

Source: M. Dixon, O. Dar, and D. Heymann. 2014. Emerging Infectious Diseases: Opportunities at the Human-Animal-Environment Interface. Veterinary Record. 174 No. 22. pp. 546-551.

6 World Economic Forum. 2015. The Global Risks 2015 Report.

7 UNISDR. 2016. Sendai Framework for Disaster Risk Reduction. 
region, and nation. Such data are subject to many errors but do indicate the top 10 severe communicable disease risks for populations. The risk varies by age, sex, livelihood, wealth, location, and medical care. Table A1.4 illustrates the mortality data reported to the World Health Organization (WHO) for two countries in the Greater Mekong Subregion (GMS). Morbidity data are also available, but subject to more errors. Data for mental illness is often especially poor.

19. This type of data is used by the medical services during health needs assessments. Such assessments enable resources to be allocated to medical services.

20. A new project creates a social and physical environment with new health risks and opportunities. For example, workers from Myanmar, with a relatively high rate of tuberculosis, who travel to Thailand, may increase the risk of tuberculosis in their host community. If they travelled to work on the project, then the change in risk of tuberculosis is a project health impact.

21. The project may also change health risks by changing the environment. Diseases that were previously rare may become more common and vice versa. For example, in Southeast Asia, improving access to the forest may increase the risk of malaria. There may also be health benefits; the risk of communicable diseases may diminish because of better living conditions, improved drinking water supplies, vaccination, distribution of insecticide-treated nets (ITN), and access to medical care.

\section{G. Severity and Likelihood}

22. The severity and likelihood of communicable diseases vary substantially. This determines their importance, or significance, and project classification. Baseline severity

Table A1.4: Comparison of Top Causes of Death at National Level

\begin{tabular}{|c|c|c|c|}
\hline Category & Disease & Myanmar (\%) & Thailand (\%) \\
\hline \multirow{7}{*}{$\begin{array}{l}\text { Noncommunicable } \\
\text { diseases }\end{array}$} & Ischemic heart disease & 7 & 14 \\
\hline & Stroke & 13 & 10 \\
\hline & Chronic obstructive lung disease & 4 & 5 \\
\hline & Liver and other cancers & & 4 \\
\hline & Kidney diseases & & 3 \\
\hline & Cirrhosis of liver & 4 & \\
\hline & Asthma & 3 & \\
\hline \multirow{2}{*}{$\begin{array}{l}\text { Injury } \\
\text { Nutritional disorders }\end{array}$} & Road injury & & 5 \\
\hline & Diabetes & 3 & 4 \\
\hline \multirow[t]{4}{*}{ Communicable diseases } & Lower respiratory infections & 9 & 9 \\
\hline & HIV and AIDS & 3 & 4 \\
\hline & Tuberculosis & 6 & \\
\hline & Diarrheal diseases & 3 & \\
\hline
\end{tabular}

Source: WHO. Country Profiles. 
and likelihood are explained and recorded in the WHO Country Statistical Profiles. The most severe communicable diseases are life-threatening, irreversible, or substantially incapacitating, and difficult to treat at the project locality.

\section{H. Malaria and Other Vector-Borne Diseases in Infrastructure Development in the Greater Mekong Subregion}

23. This section explains how vector-borne diseases (VBD) can be affected by infrastructure development. It provides knowledge for users to answer questions about VBD in project screening checklists.

24. There is a range of VBD in the GMS such as malaria, dengue, lymphatic filariasis, and Japanese encephalitis. Multidrug-resistant malaria is widespread. Common methods of control are sometimes insufficient to contain either the vectors or the diseases. Economic development is sometimes affected. ${ }^{8}$ Every new infrastructure project has the potential to increase or decrease the challenge of control. Some of the VBD have animal reservoirs. Prevalence is associated with changes to the physical and social environment, such as patterns of land use, migration, and urbanization; it is also associated with institutional changes, such as the capacity and capability of medical services to provide rapid diagnosis and treatment with effective drugs. These are all determinants of health.

25. Vectors can adapt to changing ecosystems: old vectors can colonize new habitats; previously unimportant vectors and diseases can become important. Consequently, projects should plan for the unexpected and expert advice should be sought.

26. This note summarizes some basic information about VBD. Detailed information is widely available on the web. ${ }^{9}$

\section{H.1 Basic Facts About Vector-borne Diseases in the Greater Mekong Subregion}

27. Tables A1.5-A1.7 indicate the VBDs in the GMS together with characteristics of their vectors. The availability of curative drugs and vaccination is indicated. The first group are the arthropod borne viruses (arboviruses). These are growing in importance as ecosystems change and there are probably many new ones waiting to emerge from animal reservoirs. Zika was declared a public health emergency of international concern by WHO in 2016.

28. The second group are arguably the most important: malaria and filariasis. There are two species of each.

8 ADB. 2014. Results for Malaria Elimination and Control of Communicable Disease Threats in Asia and the Pacific. Manila

9 WHO. 2014. Global Brief on Vector-Borne Diseases. 
Table A1.5: Mosquito-Borne Arboviruses

\begin{tabular}{|c|c|c|c|c|}
\hline Disease & Primary Vector Species & Reservoir & $\begin{array}{c}\text { Cure/ } \\
\text { Vaccination }\end{array}$ & Primary Location \\
\hline Dengue & Aedes aegypti & People & & Urban \\
\hline $\begin{array}{l}\text { Japanese } \\
\text { encephalitis }\end{array}$ & $\begin{array}{l}\text { Culex } \\
\text { tritaeniorhynchus }\end{array}$ & Birds, pigs & Vaccination & Rice fields \\
\hline Chikungunya & $\begin{array}{l}\text { Aedes albopictus, } \\
\text { aegypti }\end{array}$ & $\begin{array}{l}\text { Primates, bats, } \\
\text { birds }\end{array}$ & & Rural and urban \\
\hline Zika $^{a}$ & Aedes aegypti & Primates & & Rural and urban \\
\hline
\end{tabular}

a Zika can also be transmitted sexually.

Source: Sustainable Development and Climate Change Department, Asian Development Bank.

Table A1.6: Other Mosquito-Borne Diseases

\begin{tabular}{lllll} 
Disease & \multicolumn{1}{c}{ Genus of vector } & Reservoir & $\begin{array}{c}\text { Cure/ } \\
\text { vaccination }\end{array}$ & \multicolumn{1}{c|}{ Primary location } \\
\hline Malaria & Anopheles & People & Cure & $\begin{array}{l}\text { Forests and plantations, } \\
\text { rice fields }\end{array}$ \\
$\begin{array}{l}\text { Lymphatic } \\
\text { Filariasis }\end{array}$ & $\begin{array}{l}\text { Culex, Anopheles, } \\
\text { Aedes, Mansonia }\end{array}$ & $\begin{array}{l}\text { People, } \\
\text { Monkeys }\end{array}$ & Cure & $\begin{array}{l}\text { Cities, swamps, forests, } \\
\text { reservoirs }\end{array}$
\end{tabular}

Source: Sustainable Development and Climate Change Department, Asian Development Bank.

Table A1.7: Diseases with Other Vectors

\begin{tabular}{|c|c|c|c|c|c|}
\hline Disease & Vector & Genus of vector & Reservoir & $\begin{array}{c}\text { Cure/ } \\
\text { vaccination }\end{array}$ & Primary Location \\
\hline Scrub typhus & Mite & Leptotrombidium & $\begin{array}{l}\text { Small } \\
\text { mammals }\end{array}$ & $\mathrm{C}$ & $\begin{array}{l}\text { Plantations, } \\
\text { uncultivated areas }\end{array}$ \\
\hline Murine typhus & Fleas & Xenopsylla and others & Rodents & $\mathrm{C}$ & Domestic rats \\
\hline
\end{tabular}

Source: Sustainable Development and Climate Change Department, Asian Development Bank.

29. The third group are Rickettsial infections, causing typhus. These are endemic through the region but localized in specific rural and peri-urban ecosystems.

30. A range of parasitic diseases with intermediate hosts such as snails or fishes are locally important. These include schistosomiasis, opisthorchiasis, and paragonomiasis. The intermediate hosts are sometimes referred to as vectors. Curative drugs are generally available.

31. Most of these diseases are associated with poverty, except for Dengue. ${ }^{10}$ For wealthier people, prevention and protection are more affordable. Wealth means improved housing quality or location, enhanced access to diagnosis and treatment, better barriers to mosquito bites, working in jobs that require less exposure, or changes of diet.

10 K. Mulligan et al. 2015. Is Dengue a Disease of Poverty? A Systematic Review. Pathogens and Global Health. 109. No. 1 (February 2015). pp. 10-18, doi:10. 


\section{H.2 Integrated Vector Management}

32. WHO encourages stakeholders to promote integrated vector management. ${ }^{11}$ Key elements include:

(i) Evidence-based decision making;

(ii) Robust methods of monitoring and evaluation, and independent quality control;

(iii) Close collaboration between the health sector and other government sectors, as well as the private sector;

(iv) Optimal use of human and financial resources through a multi-disease control approach;

(v) Use of a range of interventions, often in combination and synergistically;

(vi) Planning and decision making delegated to the lowest possible administrative level (subsidiarity);

(vii) Advocacy and social mobilization to promote vector control in relevant agencies, organizations and civil society;

(viii) A public health regulatory and legislative framework;

(ix) Engagement with local communities to empower them and ensure sustainability of programs; and

(x) Increased capacity building at national and local levels based on a situational analysis.

33. WHO has requested ministers of environment to consider the impact on vectors for all development projects, including irrigation, hydroelectric dam construction, road building, forest clearance, housing development and industrial expansion; and ministries of finance and planning to recognize vector control as a national development issue and integrate funding for vector control into disease control budgets.

\section{H.3 Insecticide Application for Vector Control}

34. Many insecticides are suitable for vector control. Specialist advice should always be sought, but below are some general points to remember.

(i) Control requires multiple interventions at the same time. Spraying on its own is not enough.

(ii) When insecticides are distributed, stored, and applied correctly they do not harm the environment or human health. For example, DDT is still sometimes licensed for malaria control. ${ }^{12}$

(iii) Indoor residual spraying (IRS) is the method of choice when malaria mosquitoes are known to rest indoors. These insecticides are chosen for their low cost, long life and residual action. They sometimes include DDT. Householders frequently refuse to let their homes be sprayed, especially when strong-smelling insecticides like malathion are used.

11 WHO. 2014. A Global Brief on Vector-Borne Diseases.

12 The Stockholm Convention on the Reduction and Elimination of Persistent Organic Pollutants sets rules for the use of DDT for public health purposes, including its gradual phasing out. In many countries the regulatory system is not strong enough to avoid illegal transfer of DDT to the agriculture sector (See http://chm.pops.int/ default.aspx). 
(iv) Under some conditions, IRS reduces the lifespan of adult mosquitoes and has a greater impact on transmission than chemical larviciding aimed at reducing mosquito densities.

(v) Mosquito resistance to insecticides is common. This means that the chemicals have to be tested regularly against the local mosquitoes as part of the management process. There may be behavioral resistance-when the mosquitoes start resting outdoors to avoid the toxic chemical.

(vi) The method of application targets one or two species of mosquitoes. The rest will still be present and biting.

(vii) Fogging (often used to control Aedes mosquitoes) is usually just a cosmetic exercise, unless applied several times per week and at the correct time of day.

(viii) Larval control by insecticide is often not practical beyond urban areas, because larval habitats are too diffuse, or there is too much risk of environmental contamination.

(ix) The distribution of ITN is highly successful and cost-effective, especially for children, when mosquitoes bite at night. The nets can be incorporated in windows or draped over beds. They can be re-treated by households or unskilled workers once or twice per year. Long lasting insecticide-treated nets (LLIN) are often used.

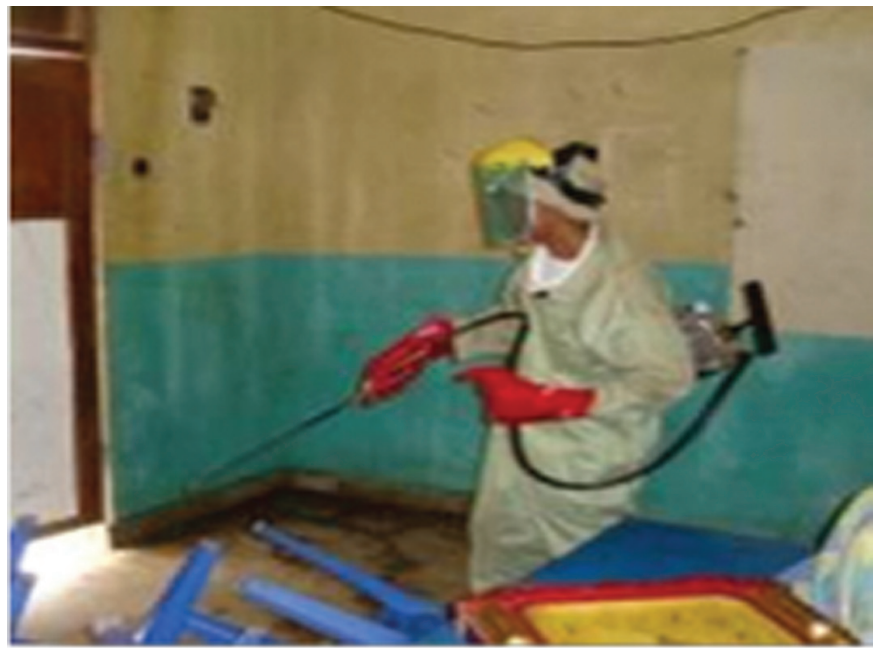

Indoor Residual Spraying in Timor-Leste (photo by World Health Organization).

35. Insecticides may also be applied to water sources to control mosquito larvae. For example, some insecticides are registered as being safe for humans to drink; they are used to control Aedes larvae breeding in water jars. 


\section{H.4 Environmental Management for Vector Control}

About $42 \%$ of the malaria burden in Asia is amenable to environmental management. ${ }^{13}$

36. In addition to the use of insecticides, vectors can often be managed by environmental methods. These can be non-toxic, relatively easy to apply, cost-effective, and sustainable. This is illustrated using malaria as an example.

37. Forests provide essential ecosystem services, including absorbing carbon dioxide and regulating water catchments. Throughout the region, forests are subject to indiscriminate felling, encroachment, mining, poaching, smuggling, drowning, harvesting of forest products, and conversion to plantations. Where forested areas are developed, indigenous forestdwelling peoples are soon outnumbered by an influx of others who can only survive because effective anti-malarials are readily available, either legally or illegally. The conclusion is that development projects and human settlements should be sited away from forests and forest edges, and that forests should be protected. The removal of tree cover to combat malaria is not a sustainable strategy.

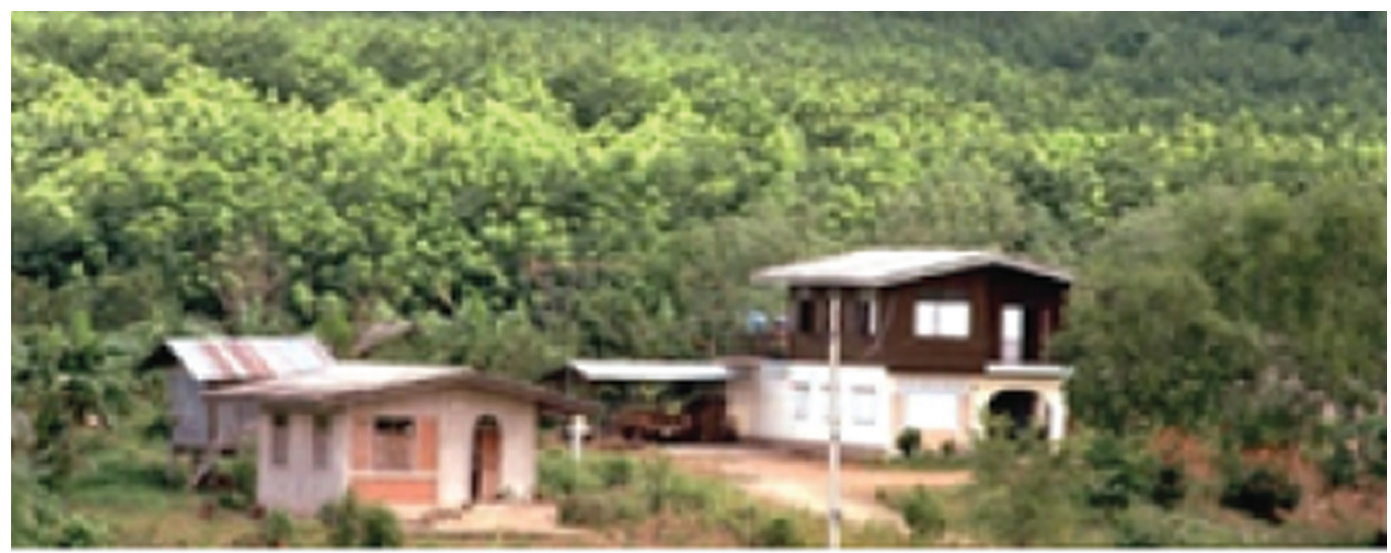

Resettlement village for a reservoir project in South Thailand. Poor laborers who live in informal housing near the forest or rubber plantations face health risks. An. minimus $s l^{14}$ was breeding in streams running through the rubber plantation (photo by Tropix Photo Library).

38. When infrastructure must be developed in or near forests, care should be taken to reduce the number of vector breeding sites during the construction and operation phases. There are many procedures for doing so and they are separated into environmental modification (done once) and manipulation (done repeatedly). ${ }^{15}$ These procedures are often only cost-effective as part of planned infrastructure development. WHO has estimated that environmental manipulation can reduce the malaria risk by about $88 \%$; and that environmental modification can reduce the malaria risk by about $80 \%$.

${ }^{13}$ WHO. 2016. Preventing Disease through Healthy Environments: A Global Assessment of the Burden of Disease from Environmental Risks. http://www.who.int/quantifying_ehimpacts/publications/preventing-disease/en/.

${ }^{14} \mathrm{Sl}=$ sensus latu = an undefined member of the species complex.

15 WHO. 1982. Manual on Environmental Management for Mosquito Control, with Special Emphasis on Malaria Vectors. Geneva. 
Successful malaria vector control has been achieved in specific ecosystems by modifying shaded streams. The modification causes the water to flow under gravel, or in pipes, so that there is no air/water surface. Syphoning systems have been used to provide automatic and periodic flushing of stream beds. Shading trees have been removed. If vectors breed in channels and ditches, these should be kept free of vegetation, steep-sided, deep, or periodically dried.

39. Malaria vector species in the GMS do not breed in cities, as there are no suitable larval habitats, or the habitats are too polluted. Control could be achieved by polluting water, but this is clearly not a sustainable strategy.

40. ITN are highly successful in some ecosystems.

41. A further method of environmental control is reducing contact between mosquitoes and people. Examples include making houses mosquito-proof and ensuring that people do not need to sleep outdoors, or enter forests at peak transmission times

42. Mosquito predators are sometimes used in larval control. The most common examples are larvivorous fish and invertebrate predators. These are only suitable where mosquitoes breed in relatively permanent habitats, like small numbers of large shallow pools, and water jars. The habitats have to be checked and restocked regularly and kept free from surface vegetation.

43. Environmental methods can also be used to control the following (Table A1.8).

Table A1.8: Environmental Methods for Controlling Vectors of Other Diseases

\begin{tabular}{ll} 
Disease & \multicolumn{1}{c}{ Summary of Environmental Method } \\
\hline Urban Lymphatic Filariasis & Improved drainage and solid waste collection \\
Japanese Encephalitis & Avoid large-scale pig raising in rice cultivation areas \\
$\begin{array}{l}\text { Scrub and Murine Typhus } \\
\text { Dengue }\end{array}$ & $\begin{array}{l}\text { Small mammal control through scrub clearance } \\
\text { Rigorous removal of rainwater collections in urban areas and sealing } \\
\text { of water jars, addition of invertebrate predators to water jars }\end{array}$
\end{tabular}

Source: Sustainable Development and Climate Change Department, Asian Development Bank.

\section{Malaria}

44. Malaria is the most important of the VBDs because of the number of people affected and the risk of serious illness and death. The malaria story varies geographically; this story applies in the GMS. There are two common species of malaria parasite in the GMS (Table A1.9), about $75 \%$ of case reports are falciparum malaria. 
Table A1.9: Two Common Species of Malaria Parasite in the Greater Mekong Subregion

\begin{tabular}{ll}
\hline Species of malaria & Characteristics \\
Falciparum & - Serious and deadly \\
& - Dore common resistance common \\
Vivax & - Less serious \\
& - Less common \\
& - Larger geographical distribution \\
& - Less drug resistance
\end{tabular}

Source: Sustainable Development and Climate Change Department, Asian Development Bank.

\section{I.1 Basic facts}

(i) Much of the malaria in the GMS is associated with laborers working in forests or plantations.

(ii) Drug resistance is growing fast. Chloroquine has long been abandoned for falciparum malaria. For vivax malaria, chloroquine resistance rates of $17 \%$ have been reported from Cambodia. ${ }^{16}$ Artemisinin resistance is growing and we are running out of curative drugs.

(iii) Poor quality and counterfeit drugs are in circulation.

(iv) Rates of new infection may vary seasonally.

\section{I.2 Distribution of Malaria in the Greater Mekong Subregion}

45. Good maps of the predicted distribution of malaria and its vectors are available ${ }^{17}$ but maps of actual distribution may not be available. Figure A1.3 indicates the predicted distribution of falciparum malaria in the GMS. Maps such as this are insufficient to determine the malaria status of a project location. If in doubt, consult a specialist. Malaria has been successfully controlled in some areas, such as central Thailand, but is still common along forested national borders and elsewhere. Thailand's success was based on a combination of rapid diagnosis and treatment, distribution of ITNs, indoor residual spraying, economic development, and deforestation.

\section{The Malaria Mosquito}

46. Malarious locations have many biting mosquitoes that may or may not transmit malaria. There are usually just one or two species that both can and do transmit malaria. They are the primary and secondary vectors and belong to the genus Anopheles (An.). The three species below are a species complex. ${ }^{18}$ The most important is An. dirus. Their adult and larval habitats are indicated in Table A1.10.

${ }^{16}$ Vivax Working Group. 2016. The Asia Pacific Malaria Elimination Network.

17 Oxford University. 2016. Malaria Atlas Project.

${ }^{18}$ Species complex means there are several genetically differentiated subspecies that are hard to tell apart in appearance and with a differing ability to transmit malaria. 


\section{Figure A1.3: Predicted Distribution of Falciparum Malaria in the Greater Mekong Subregion}

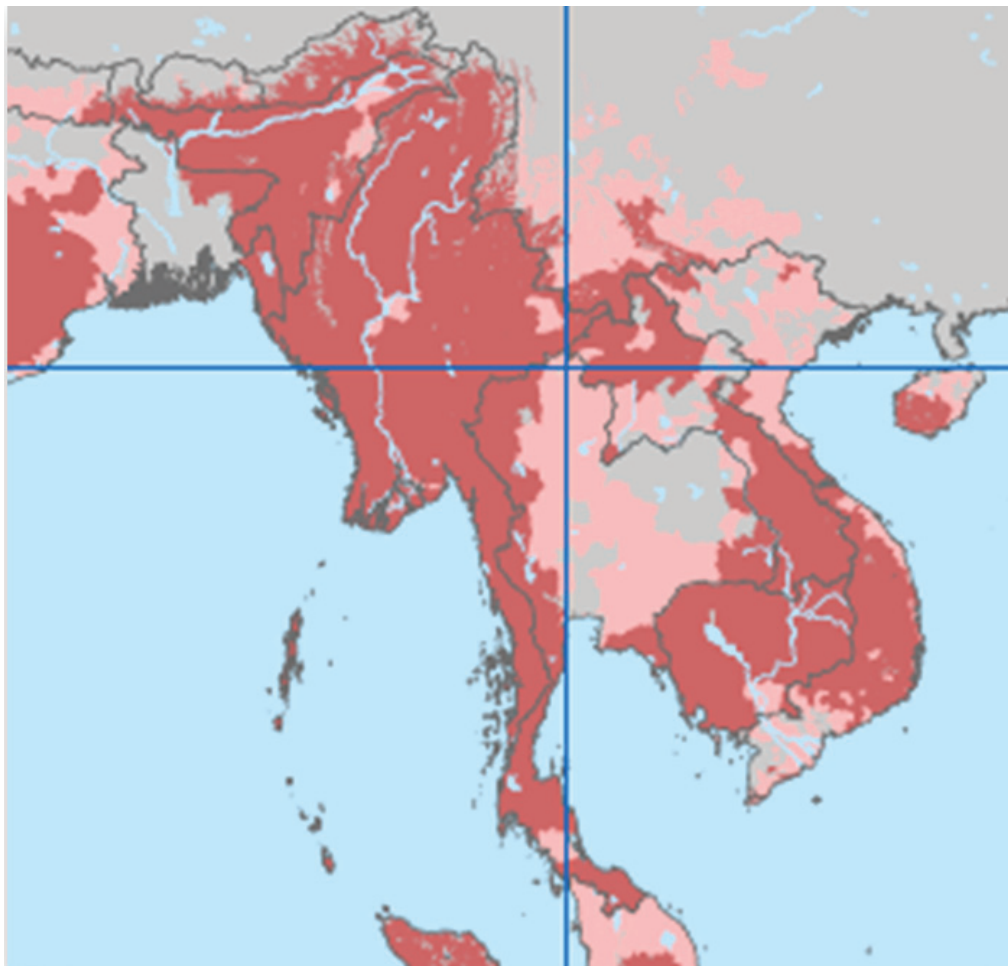

Grey $=$ Falciparum-free, Red $=$ stable transmission, Pink = unstable transmission .

Source: Sustainable Development and Climate Change Department, Asian Development Bank.

Table A1.10: The Malaria Vectors

Vector Species Complex

An. dirus

An. minimus

An. sundaicus

Source: Sustainable Development and Climate Change Department, Asian Development Bank.

\section{Larval Habitat}

Forested mountains and foothills, Larvae in temporary, standing, or cultivated forests, plantations, and slowly moving water under shade, forest fringes often in deep forest. Secondary sites in shaded temporary puddles

Forested and deforested hills, forest fringes, agricultural fields including traditional rice systems

Open mangrove; coastal lagoons; manmade shrimp ponds, inland Larvae in streams, tree plantations, rice fields, irrigation canals

Larvae in brackish (slightly salty), sunlit water brackish water canals 
47. In summary:

(i) These mosquitoes bite people at night, or at dusk, and have preferences for feeding indoors and outdoors, on people or on animals. This affects adult control strategies.

(ii) They do not breed in cities, often because the environment is too polluted. They may be found in periurban zones if conditions of light and shade and cleanliness of water suit them.

(iii) The mosquito's flight range is at least 3 kilometers.

(iv) Larval habitats are shallow water. They do not favor steeply sloping reservoirs.

(v) Mosquito abundance and adult longevity may vary seasonally and this can cause major changes in how disease is transmitted.

\section{I.3 Malaria Control and Elimination}

48. Successful malaria control depends on establishing multiple barriers to ensure that transmission is reduced and people are not infected (Table A1.11). These barriers should be always maintained. Responsibilities should be shared between the health sector and the project management.

49. A possible malaria mitigation hierarchy for communities is indicated in Table A1.12 and for workers in Table A1.13.

\section{I.4 Chemical Resistance and Malaria}

50. Both the malaria parasite and the vector mosquito have developed various resistance to the chemicals used to control them (Table A1.14), which has become a serious challenge. There is an ongoing race to produce new chemicals and malaria may be winning.

\section{Table A1.11: Multiple Barriers for Malaria Control}

\begin{tabular}{ll} 
Barrier & \multicolumn{1}{c}{ Note } \\
\hline Larval Habitat & Remove or modify. Consider risks in engineering design. Check regularly \\
\hline Location & Locate projects and communities far from forests and tree plantations \\
\hline Reduce Contact & $\begin{array}{l}\text { Social marketing of insecticide-treated nets, assure repeat treatments of } \\
\text { nets; build better houses in better locations }\end{array}$ \\
\hline Spraying & $\begin{array}{l}\text { Indoor residual spraying, test regularly for resistance, obtain community } \\
\text { license to operate }\end{array}$ \\
\hline Surveillance & $\begin{array}{l}\text { Collect statistics by species, age, sex, location, occupation, and season } \\
\text { confirm diagnoses test for resistance, identify vector species }\end{array}$ \\
\hline Poverty Reduction & $\begin{array}{l}\text { Enables people to look after their own families, purchase nets and drugs, } \\
\text { build a better house } \\
\text { Distribute and assure stocks of diagnostic kits }\end{array}$ \\
\hline Rapid Diagnosis & $\begin{array}{l}\text { Distribute and assure stocks of effective treatment, test regularly for } \\
\text { resistance and counterfeit drugs }\end{array}$ \\
\hline
\end{tabular}

Source: Sustainable Development and Climate Change Department, Asian Development Bank. 
Table A1.12: Examples of the Mitigation Hierarchy for Community Malaria in an Infrastructure Project

\begin{tabular}{lll} 
Mitigation Hierarchy & \multicolumn{1}{c}{ Action } & \multicolumn{1}{c|}{ Example } \\
Avoid & Design out & $\begin{array}{l}\text { Locate project far from forest and } \\
\text { tree plantations }\end{array}$ \\
\hline Abate at Site & Add to design & $\begin{array}{l}\text { Modify larval habitats } \\
\text { Ansecticide spraying }\end{array}$ \\
\hline Add to Operations & $\begin{array}{l}\text { Coordinate Integrated Pest } \\
\text { Management and Integrated } \\
\text { Vector Management }\end{array}$ & $\begin{array}{l}\text { Insecticide-treated nets and } \\
\text { repellents; prophylaxis }\end{array}$ \\
\hline Repair & Personal protection & $\begin{array}{l}\text { Rapid diagnosis and effective } \\
\text { treatment }\end{array}$ \\
\hline Compensate & Medical treatment & $\begin{array}{l}\text { Provide funding to the health care } \\
\text { sector to cope with additional } \\
\text { medical demands }\end{array}$
\end{tabular}

Source: Sustainable Development and Climate Change Department, Asian Development Bank.

Table A1.13: Examples of the Mitigation Hierarchy for Occupational Malaria in an Infrastructure Project

\begin{tabular}{|c|c|c|}
\hline Mitigation Hierarchy & Action & Example \\
\hline $\begin{array}{l}\text { Siting of } \\
\text { Construction Camps }\end{array}$ & Design & $\begin{array}{l}\text { At least } 2 \text { kilometers from forests and tree } \\
\text { plantations }\end{array}$ \\
\hline Design of Camps & Add to design & $\begin{array}{l}\text { Attention to potential breeding sites; design and } \\
\text { maintain channels and ditches }\end{array}$ \\
\hline Abate at Receptor & Personal protection & $\begin{array}{l}\text { Supply insecticide-treated nets and repellents; } \\
\text { incorporate repellents in clothing; control night- } \\
\text { time working; direct observation of workers } \\
\text { taking prophylaxis and random blood tests; } \\
\text { screen buildings; screen workers for malaria on } \\
\text { arrival; insecticide spraying }\end{array}$ \\
\hline Repair & Medical treatment & $\begin{array}{l}\text { Medical facility onsite providing rapid diagnosis } \\
\text { and treatment; In-patient facilities with } \\
\text { emergency evacuation for difficult cases }\end{array}$ \\
\hline Compensate & Finance and insurance & Recovery leave; repatriation \\
\hline
\end{tabular}

Source: Sustainable Development and Climate Change Department, Asian Development Bank.

Table A1.14: Type of Resistance

\begin{tabular}{|ll|}
\hline Type of Resistance & \multicolumn{1}{c}{ Note } \\
\hline Parasite Resistance & $\begin{array}{l}\text { R1 means resistance in laboratory tests; R2 means failure of } \\
\text { medicine to cure patient }\end{array}$ \\
\hline Mosquito Resistance & $\begin{array}{l}\text { Tolerance of mosquito to chemical; Behavioral resistance means } \\
\text { mosquito avoids contact with chemical }\end{array}$ \\
\hline People Resistance & Refusal to allow chemical spraying in or near home \\
\hline
\end{tabular}

Source: Sustainable Development and Climate Change Department, Asian Development Bank. 
51. There is multiple drug-resistant malaria in the GMS. Artemisinin-based combination therapies (ACTs) are recommended by $\mathrm{WHO}^{19}$ and supported by the Asian Development Bank $^{20}$ through the Regional Malaria and Other Communicable Disease Threats Trust Fund and the associated Results for Malaria Elimination and Communicable Diseases Threats in Asia and Pacific. ${ }^{21}$

52. Artemisinin resistance has occurred because of several factors: poor treatment practices, inadequate patient adherence to prescribed antimalarial regimens, and the widespread availability of oral artemisinin-based monotherapies and substandard forms of the drug. The geographic scope of the problem could widen quickly and have dire public health consequences. The impact of infrastructure projects on the spread of resistance can be significant, through intensification of local transmission, and through the mobility of construction workers, informal migrants or seasonal laborers. The spread or independent emergence of artemisinin resistance in other parts of the world could pose a major health security risk as no alternative antimalarial medicine is available at present with the same level of efficacy and tolerability as ACTs.

\section{I.5 Malaria and the Social Gradient}

53. Malaria is largely a disease of the rural poor. There is considerable variation in malaria rates with socioeconomic status. As people acquire more wealth, they are better able to protect themselves and their families. They can reduce contact with mosquitoes through better housing and better screening. They can buy ITNs, mosquito repellents, and malaria prophylaxis. They can access better diagnosis and treatment. Figure A1.4 illustrates the evidence of the association

Figure A1.4: History of Malaria Associated with House Type in the Forests of Assam

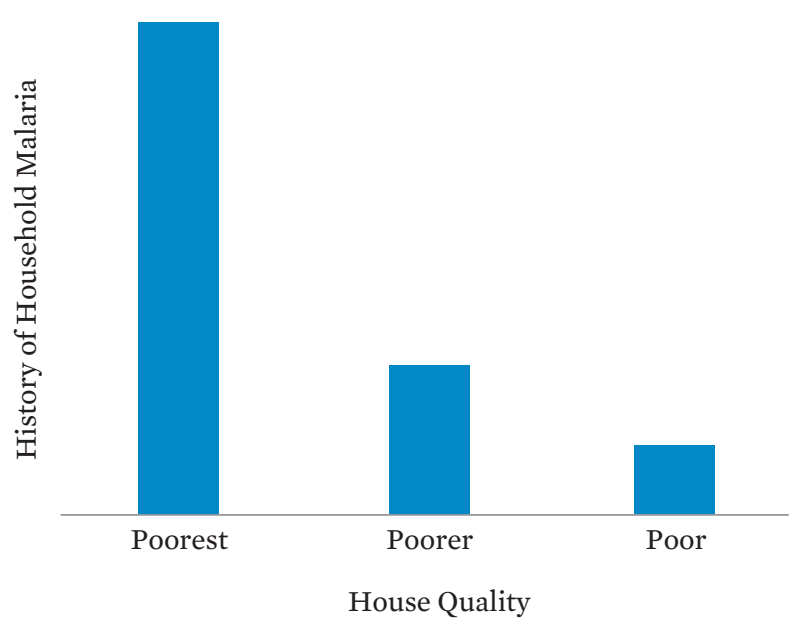

Source: Sustainable Development and Climate Change Department, Asian Development Bank.

19 WHO. 2018. QEA on Artemisinin Resistance.

${ }^{20}$ ADB. 2015. Malaria Elimination. Manila.

${ }^{21}$ ADB. 2017. Technical Assistance for Results for Malaria Elimination and Control of Communicable Disease Threats in Asia and the Pacific. Manila. 
between malaria risk and poverty ${ }^{22}$ using a study from the forests of Assam. ${ }^{23}$ In Viet Nam, the risk of malaria is strongly associated with social and environmental factors. These can be summarized by the percentage of the population living under the poverty line and the percentage of forest cover. ${ }^{24}$

54. Malaria is also associated with human migration. There may be 3-5 million migrants in the GMS. ${ }^{25}$ Communities in the GMS may be pushed by poverty and lack of opportunity from densely populated areas to less populated areas. ${ }^{26}$ At their destinations, they may still lack land ownership, proper housing and basic assets, and only have access to "dirty, dangerous and disliked" jobs. Destinations are often the forest and forest fringe. They may become caught in a cycle of poverty when greater exposure to malaria leads to reduced productivity. The act of migration does not alleviate their poverty. ${ }^{27}$ This process has been reported from Cambodia and elsewhere in the GMS. ${ }^{28}$ Migrants from non-malarious zones are more vulnerable to malaria than local populations. They may lack partial immunity, knowledge of self-protection, and knowledge of appropriate treatment. They may suffer debilitating attacks of malaria requiring costly treatment. They may not be eligible for treatment under national malaria programs or be afraid of accessing it because of an illegal status.

55. Poor knowledge of malaria transmission and prevention is also a significant risk factor in the GMS. Vulnerable communities include security personnel engaged on border patrols; forest workers who are hunting, logging and fishing; construction and mine workers building dams, roads and mines; and seasonal workers engaged in farming and plantations.

\section{I.6 Health Determinants of Malaria for Use in Health Impact Assessments}

56. The concept of health determinants is explained in the main text in the section Definition of Health. The following table provides some examples of the determinants of malaria (Table A1.15).

\section{J. Lymphatic Filariasis}

57. Lymphatic filariasis is one of the leading causes of disability worldwide with $63 \%$ of population at risk in the WHO Southeast Asia Region ${ }^{29}$ and over 38 million in the Western Pacific Region. ${ }^{30}$ There is a global eradication campaign using mass drug administration. Lymphatic filariasis is highly endemic in Myanmar (Figure A1.5), but has been controlled in

${ }^{22}$ The source defines house type as bamboo, kucha, and pucka and we have interpreted the meaning.

${ }^{23}$ K. Yadav et al. 2014. Socio-Economic Determinants for Malaria Transmission Risk in an Endemic Primary Health Centre in Assam, India. Infectious Diseases of Poverty. 3:19.

${ }^{24}$ B. Manh et al. 2011. Social and Environmental Determinants of Malaria in Space and Time in Viet Nam. International Journal for Parasitology. 41. No. 1. pp. 109-116.

${ }^{25}$ ADB. 2017. Technical Assistance for Results for Malaria Elimination and Control of Communicable Disease Threats in Asia and the Pacific. Manila.

${ }^{26}$ A pull from poor rural to wealthier urban areas also occurs

${ }^{27}$ Yanyong Inmuong. 2016. Personal Observation. 19 March.

${ }^{28}$ P. Guyant et al. 2015. Malaria and the Mobile and Migrant Population in Cambodia: A Population Movement Framework to Inform Strategies for Malaria Control and Elimination. Malaria Journal. 14 (20 June 2015).

${ }^{29}$ WHO/SEARO. 2016. Lymphatic Filariasis.

${ }^{30}$ WHO/WPRO. 2016. Lymphatic Filariasis Factsheet. 
Table A1.15: Health Determinants of Malaria

Category of Health

Determinant

Environmental

Social

Institutional
Specific Determinants

Larval habitats restrict malarious locations. Adult mosquitoes flight range is 2-3 kilometers.

Poor people and migrants have less access to effective treatment and less opportunity to protect themselves. The interaction between non-immune migrants and partially immune locals can deepen the social gradient.

Government malaria control services vary in quality and quantity. Various nongovernment organizations offer services. Malaria statistics are of variable quality. People may seek treatment from traditional healers or private medicine. There are counterfeit and poor quality drugs in circulation.

Risk of malaria varies with age, sex, and hereditary factors.
Example

Forest edges

There is a social gradient

Diagnosis often presumptive and inaccurate

Poor, migrant, less educated men often most vulnerable

Source: Sustainable Development and Climate Change Department, Asian Development Bank.

Figure A1.5: Lymphatic Filariasis is Endemic in 39 Districts of Myanmar

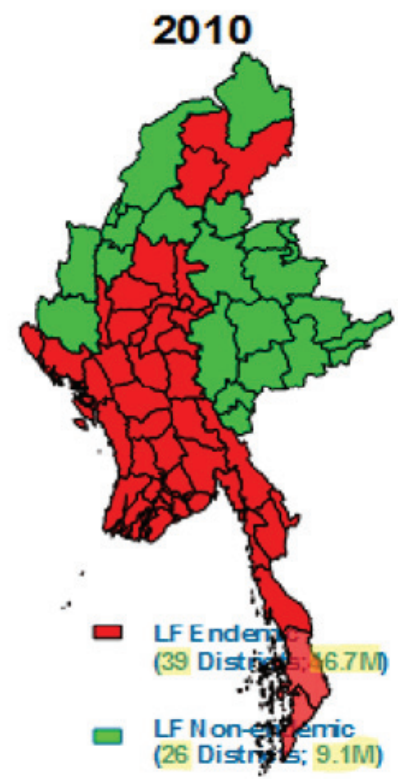

Source: WHO/SEARO. 2016. Lymphatic Filariasis. 
Cambodia, Thailand, and Viet Nam because of successful mass drug administration. The two main species of the parasite are Bancroftian and Brugian (Table A1.16). There are many local differences in the pattern of rural transmission in Asia generally.

58. Filariasis is both an urban and rural disease. The urban vector in Myanmar and elsewhere is usually Culex quinquefasciatus. This successful nuisance mosquito breeds in polluted water bodies and is often found at high densities. ${ }^{31}$ Table Al.17 summarizes some major determinants of urban transmission. Improved sanitation and solid waste disposal are key to vector control.

59. Urban infrastructure development projects can play a significant role in reducing vector breeding.

60. The determinants of the rural distribution of lymphatic filariasis are complex and vary between ecosystems.

Table A1.16: General Components of Lymphatic Filariasis Transmission

\begin{tabular}{llllll} 
Type of Filariasis & \multicolumn{1}{c}{ Vectors } & Reservoir & $\begin{array}{c}\text { Cure/ } \\
\text { Vaccination }\end{array}$ & Location & Importance \\
\hline $\begin{array}{l}\text { Bancroftian } \\
\text { Filariasis }\end{array}$ & $\begin{array}{l}\text { Culex, Aedes, } \\
\text { Anopheles }\end{array}$ & People & Cure & Urban and rural & $90 \%$ of cases \\
$\begin{array}{l}\text { Brugian } \\
\text { Filariasis }\end{array}$ & $\begin{array}{l}\text { Mansonia, } \\
\text { Anopheles }\end{array}$ & Monkeys & Cure & Rural & 10\% of cases \\
\hline
\end{tabular}

Source: Sustainable Development and Climate Change Department, Asian Development Bank.

Table A1.17: Determinants of Urban Lymphatic Filariasis

\begin{tabular}{|c|c|c|}
\hline Determinant & General characteristics & Implications for transmission \\
\hline Environment & $\begin{array}{l}\text { Poor sewerage, drainage and } \\
\text { sanitary facilities }\end{array}$ & $\begin{array}{l}\text { Creation of favorable conditions for breeding of } \\
\text { vectors, especially Culex quinquefasciatus }\end{array}$ \\
\hline Demography & $\begin{array}{l}\text { High population density and by } \\
\text { creation rate }\end{array}$ & $\begin{array}{l}\text { Human crowding favors transmission. Influx of } \\
\text { new infections from rural to urban areas. }\end{array}$ \\
\hline Economy & Poorer segment of population & $\begin{array}{l}\text { Poor quality houses with little or no mosquito } \\
\text { proofing. Personal protection measures against } \\
\text { mosquito bites may be unaffordable. }\end{array}$ \\
\hline Knowledge & $\begin{array}{l}\text { Low educational level and } \\
\text { knowledge about the disease }\end{array}$ & $\begin{array}{l}\text { Little understanding of disease transmission. } \\
\text { The importance of preventive measures not } \\
\text { clearly envisaged. }\end{array}$ \\
\hline Behavior & $\begin{array}{l}\text { Mixed cultures, low social } \\
\text { coherency. Privacy and } \\
\text { individualism given high value }\end{array}$ & $\begin{array}{l}\text { Reluctance toward diagnostic and clinical surveys. } \\
\text { Opposition to mass treatment campaigns. }\end{array}$ \\
\hline
\end{tabular}

Source: P. Simonsen and M. Mwakitalu. 2013. Urban Lymphatic Filariasis. Parasitology Research. 112. No. 1 (January 2013). pp. 35-44.

${ }^{31}$ P. Simonsen and Mwakitalu E. 2013. Urban Lymphatic Filariasis. Parasitology Research 112. No. 1 (January 2013). pp. 35-44. 


\section{K. Dengue}

61. Dengue virus (DENV) causes more human morbidity and mortality than any other vector-borne virus and is a growing threat. ${ }^{32}$ It occurs widely across the region, and there are currently no vaccines and no cures. Vector control is essential and can be effective, but only when implementation is proactive, expedient, comprehensive, and sustained, which it rarely is. The primary vector, Aedes aegypti, thrives in cities where it breeds in temporary rainwater collections, water storage jars, drip trays, flower pots, and ant traps. The eggs are drought resistant and can be transported in human goods such as car tyres. The adults bite during the day both inside and outside houses and they have a short flight range. There are no animal reservoirs and the virus is distributed by human movement. The secondary vector is Aedes albopictus.

62. Infrastructure development projects in urban areas can affect the abundance of vector breeding sites.

\section{Japanese Encephalitis}

63. Japanese encephalitis is distributed throughout the region with varying importance. There are often seasonal epidemics, for example in Northern Thailand. It is the leading cause of viral encephalitis in Asia and can be fatal. It is associated with rice growing areas that attract water birds, the main reservoir host. Pigs act as an amplifying host. Unlike the other arboviruses, there is an effective vaccine.

64. The key message for infrastructure development is to avoid pig rearing in rice cultivation areas.

\section{Scrub Typhus and Murine Typhus}

65. The diseases are endemic throughout the GMS. The reservoir hosts are small mammals. The vector of scrub typhus is a mite. The vector of murine typhus is a flea. A recent study suggested that one quarter of rural hospital admissions with fever may be attributable to these infections. ${ }^{33}$ The patients tended to be young adult males, suggesting an occupational link. Hazardous localities are the edges of undisturbed ecosystems, where small mammals are abundant, and plantations with excessive ground cover. Murine typhus is associated with domestic rats and found in peri-urban areas and villages where rats are abundant. There is an opportunity to control both through environmental management. Infrastructure development projects could affect the ecosystems where the reservoir hosts are abundant.

32 S. Bhatt et al. 2013. The Global Distribution and Burden of Dengue. Nature. 496. No. 7446 (7 April 2013). pp. 504507.; R. Reiner et al. 2016. Quantifying the Epidemiological Impact of Vector Control on Dengue. ed. Eva Harris, PLOS Neglected Tropical Diseases. 10, no. 5 (26 May 2016); C. Simmons et al. 2012. Dengue. New England Journal of Medicine 366. No. 15 (12 April 2012). pp. 1423-1432.

33 P. Simaly et al. 2006. Rickettsial Infections and Fever. Vientiane, Lao People's Democratic Republic. Emerging Infectious Diseases. 12. No. 2 (February 2006). pp. 256-262. 


\section{N. More Information}

67. Information about all the diseases described is available on WHO, CDC and other health websites.

Regional malaria specialists

(i) APMEN, Asia Pacific Malaria Elimination Network. http://apmen.org/

(ii) MAP, Malaria Atlas Project at Oxford University, www.map.ox.ac.uk/

(iii) MORU, Mahidol Oxford Tropical Medicine Research Unit, http://www.tropmedres. ac/home . MORU have offices in most GMS countries. Contact: Dr. Richard Maude (Head of Malaria Epidemiology), Nattwut Aekaphirat (Statistician, Malaria Epidemiology/Modelling). There is a project to identify malaria hot spots in the GMS region and to establish a regional database. Before quoting country specific data, permission is required from National Malaria Control Programs.

(iv) Malaria Consortium, /www.malariaconsortium.org/ 


\section{APPENDIX 2 \\ Rapid Health Impact Assessment Scoping Template}

\section{Introduction}

This appendix contains a rapid scoping template (RST) for the health impact assessment of Asian Development Bank projects. It includes an example completed template. Template headings and standard text are in blue. The standard text can be amended as appropriate.

\section{Template}

\begin{tabular}{|l|}
\hline A. Basic data \\
\hline A.1 \\
\hline A.2 \\
\hline A.3 \\
\hline A.4 \\
\hline A.5 \\
\hline B. Project Overview \\
\hline B1. Does the project have an explicit health objective? if so, what is it? \\
\hline C. Geographical scope of assessment \\
\hline D. Temporal scope of assessment \\
\hline D.1 Construction: \\
\hline D.2 Operation: \\
\hline D.3 Decommissioning, rehabilitating, or extending: \\
\hline
\end{tabular}


Template continued

E. Community scope of assessment

E.1 Gender scope:

E.2 Age scope:

E.3 Ethnic minority scope:

E.4 Resettlement scope:

E.5 Stakeholders:

E.6 Migrants:

E.7 Other:

F. Health impact initial scope of health priorities (opportunities and concerns)

F.1 Communicable diseases:

F.2 Noncommunicable diseases:

F.3 Nutritional issues:

F.4 Injuries:

F.5 Mental health and well-being:

G. Health determinants that may be affected (opportunities and concerns)

G.1 Physical environment:

G.2 Social environment:

G.3 Health supportive institutions:

H. Health aspects that can be addressed in the project

H.1 Addressed through design: 
Template continued

\section{H.2 Addressed through other mitigation:}

H.3 Addressed through health improvement:

H.4 Addressed though medical service provision:

H.5 Addressed through commissioned research:

\section{H.6 Other:}

\section{Initial scope of work for HIA consultant(s)}

\section{I.1 Lead consultant:}

A lead consultant will be appointed who has knowledge and experience of HIA and the project sector.

\section{I.2 National consultant:}

A national consultant will be appointed who has knowledge and experience of public health in the national context.

\section{I.3 Scoping:}

Review the rapid scope and suggest changes.

\section{I.4 Training workshop:}

The consultants will include an HIA training workshop at project kick-off for professional stakeholders based on the project.

\section{I.5 Literature review:}

Undertake a literature review of the health issues identified and to determine if additional health issues should be included.

\section{I.6 Baseline:}

Collect secondary data regarding the status of items in $\mathrm{f}$ and $\mathrm{g}$ from government, academic, and NGO sources, and from key informant interview. Triangulate. Assess the accuracy of routinely collected health data at local level. assess the capabilities and capacity of the current health services. assess the current health needs of the existing communities.

Identify gaps.

Propose a plan for primary data collection that is statistically and ethically sound, and achievable in the time available.

\section{I.7 Priorities:}

Identify health priorities.

\section{I.8 Indicators:}

Identify suitable indicators for comparing before and after health conditions. 
Template continued

\section{I.9 Occupational health and safety:}

The consultants shall determine whether an occupational health and safety policy, plan and management system is included in the construction plan.

\section{I.10 Economic analysis:}

Develop model for each disease group as described under section $\mathrm{f}$, which estimates cost of such diseases accrued through out-of-pocket expenditures for treatment and healthy life years lost because of disease (disability adjusted life years, DALYs). ${ }^{34}$

\section{I.11 Recommendations:}

The consultants will prepare justified recommendations for enhancing section $\mathrm{H}$, based on prioritization of health issues.

\section{I.12 Rapid HIA report}

Draft a rapid HIA report after validating the findings with the relevant stakeholders and include health related indicators in the project monitoring and evaluation (M\&E) framework.

\section{J. Next steps}

- Draft full terms of reference (TOR) for HIA consultant and add health indicator analysis in TOR for project economist.

- Discuss TOR with government counterparts.

- Include HIA activities project main text, problem tree, design and monitoring framework, and milestone and HIA aspects in economic analysis.

\section{Example}

\section{A. Basic data}

\section{A.1 Date:}

28 February 2017

\section{A.2 Project name:}

SRI: Mahaweli water security investment program

\section{A.3 Project location:}

Sri Lanka; provinces: central, eastern, north central and north western

\section{A.4 Project officer:}

Lance Gore, SAER

\section{A.5 Type of project:}

Irrigation and drainage

\section{B. Project overview}

The investment program helps the government to complete outstanding water conveyance investments under the Mahaweli Development Program. it includes three projects: (i) the Upper Elahera canal project; (ii) the North Western Province canal project; and (iii) the Minipe Left Bank Canal Rehabilitation Project with an expected annual water supply of more than $700 \mathrm{mcm}$ from the Mahaweli river to the target systems. the completion of MDP is a key priority of the

continued on next page

\footnotetext{
${ }^{34}$ Healthy life years lost (or Disability Adjusted Life Years, DALYs) are the sum of life years lost to premature mortality (deaths before the age of 80 years for males and 82.5 for females) and the years lived with disability, given as a number or as a standardized rate per 100,000.
} 


\section{Template continued}

government, as it will maximize the productivity of the water sources of the Mahaweli river basin by transferring water to water-deficit areas in the northern dry zone for irrigation, drinking/ household, commercial, and industrial purposes. this will, in turn, accelerate local and national economic growth and living standards of local people by providing opportunities and resources to improve their household incomes, food and water security.

The projects will provide better water supplies to water-deficit areas in the dry zone. This is particularly urgent given that health and other social problems, mainly also higher poverty rates than the country's average, are observed to be prevailing in the project area. based on the field surveys, meetings with government officials, community leaders and members of communitybased organizations, the major health problems are:

- scarcity of clean drinking water (high salt content)

- increasing number of patients suffering from chronic kidney disease of unknown origin (CKDu)

- excessive and unsafe use of agrochemicals

- respiratory problems associated with dust

B.1 Does the project have an explicit health objective? if so, what is it?

- Reduce noncommunicable diseases associated with water pollution by agrochemicals

- Reduce communicable diseases associated with water shortage and fecal contamination of drinking supplies

\section{Geographical scope of assessment}

- Water offtake structures on Mahaweli

- Canals

- Northern dry zone that receives water supply

- Areas that receive drainage waters

- Areas downstream of offtake structures where water supply is diminished

\section{Temporal scope of assessment}

\section{D.1 Construction:}

Included

\section{D.2 Operation:}

Included

D.3 Decommissioning, rehabilitating, or extending:

The project includes a rehabilitation component.

\section{E. Community scope of assessment}

\section{E.1 Gender scope:}

The differential exposure of males and females must be determined.

\section{E.2 Age scope:}

Young children and elderly are especially vulnerable.

\section{E.3 Ethnic minority scope:}

The distribution of ethnic minorities must be determined.

\section{E.4 Resettlement scope:}

The amount of resettlement required must be determined.

\section{E.5 Stakeholders:}

The interests of professional stakeholders must be determined. 
Template continued

\section{E.6 Migrants:}

The project is expected to attract migrants during construction.

\section{E.7 Other:}

\section{F. Health impact initial scope of health priorities}

F.1 Communicable diseases:

- Waterborne diseases associated with fecal contamination

- Vector-borne diseases including malaria and Japanese encephalitis

F.2 Noncommunicable diseases:

- Diseases associated with consumption of water contaminated with salts and agrochemicals such as CKDu

- Diseases associated with inhalation of dust and particulates

F.3 Nutritional issues:

To be determined.

\section{F.4 Injuries:}

Associated with transportation, construction sites, communal violence, domestic violence.

\section{F.5 Mental health and well-being:}

Suicide rates, especially associated with agrochemicals.

\section{G. Health determinants that may be affected}

G.1 Physical environment:

- Quality and quantity of water supply for irrigation, industry, and domestic use

- Safe disposal of agricultural drainage

G.2 Social environment:

- Price of drinking water

- Employment opportunities especially for women

G.3 Health supportive institutions:

Capacity and capability of medical services and drinking water supply services.

\section{H. Health aspects that can be addressed in the project}

H.1 Addressed through design:

- Creation or destruction of vector breeding sites

- Safe drainage water disposal system

- Domestic water supply system

- Domestic waste disposal system

H.2 Addressed through other mitigation:

Vector control.

H.3 Addressed through health improvement:

Domestic water supply.

H.4 Addressed though medical service provision:

To be determined.

H.5 Addressed through commissioned research: Epidemiology of CKDu in Sri Lanka.

H.6 Other: 
Template continued

\section{Initial scope of work for HIQ consultant(s)}

\section{I.1 Lead consultant:}

A lead consultant will be appointed who has knowledge and experience of HIA and the project sector.

\section{I.2 National consultant:}

A national consultant will be appointed who has knowledge and experience of public health in the national context.

\section{I.3 Scoping:}

Review the rapid scope and suggest changes.

\section{I.4 Training workshop:}

The consultants will include an HIA training workshop at project kick-off for professional stakeholders based on the project.

\section{I.5 Literature review:}

Undertake a literature review of the health issues identified and to determine if additional health issues should be included.

\section{I.6 Baseline:}

- Collect secondary data regarding the status of items in F and G from government, academic, and NGO sources, and from key informant interview. Triangulate. Assess the accuracy of routinely collected health data at local level. Assess the capabilities and capacity of the current health services. Assess the current health needs of the existing communities.

- Identify gaps.

- Propose a plan for primary data collection that is statistically and ethically sound, and achievable in the time available.

\section{I.7 Priorities:}

Identify health priorities.

\section{I.8 Indicators:}

Identify suitable indicators for comparing before and after health conditions.

- Concentration of salts and agrochemicals in drainage water and drinking water

- Concentration of total coliforms in drinking water supplies

- Reported suicide rates in project affected communities

- Vector abundance

- Reported traffic injury rates

\section{I.9 Occupational health and safety:}

The consultants shall determine whether an occupational health and safety policy, plan and management system is included in the construction plan.

\section{I.10 Economic analysis:}

Develop model for each disease group as described under section $\mathrm{f}$ which estimates cost of such diseases accrued through out-of-pocket expenditures for treatment and healthy life years lost because of disease (disability adjusted life years, DALYs) (footnote 34).

\section{I.11 Recommendations:}

The consultants will prepare justified recommendations for enhancing section $\mathrm{H}$, based on prioritization of health issues.

\section{I.12 Rapid HIA report:}

Draft a rapid HIA report after validating the findings with the relevant stakeholders and include health related indicators in the project M\&E framework. 


\section{Template continued}

\section{J. Next steps}

- Draft full tor for HIA consultant and add health indicator analysis in tor for project economist.

- Discuss tor with government counterparts.

- Include HIA activities project main text, problem tree, design and monitoring framework, and milestone and HIA aspects in economic analysis

Text in blue is standard template and can be amended. 


\section{APPENDIX 3 \\ Health Impact Assessment Terms of Reference}

1. The Terms of Reference (TOR) for procuring the services of consultants to undertake impact assessments are often complex and project-specific. There are often a series of activities associated with a project and each may require the services of consultants and a separate TOR. These activities include:

(i) Reconnaissance missions,

(ii) Project design missions,

(iii) Rapid health impact assessment (HIA), and

(iv) Feasibility studies.

2. These activities are likely to be initiated through the environmental safeguards or poverty and social analysis processes. Generic TORs have been developed under the assumption that a public health specialist with the appropriate HIA competency is being added to a mission that includes a wide range of other specialists. The TORs for public health are intended to ensure that health and safety is addressed in a competent manner. Key elements include:

(i) The HIA lead must have a strong public health background (public health education, such as a master's degree in public health), training in HIA, and relevant experience in public health and HIA. Skills should include gender-sensitivity, speaking the local language, and capabilities to interact with people with different cultural backgrounds.

(ii) The assessment should conform to the definitions, procedures, methods and concepts provided in this sourcebook, and explain when divergence is necessary.

(iii) The public health TOR below is assumed to be embedded in a larger TOR that includes additional administrative requirements.

(iv) Each TOR is subdivided by: knowledge, skills, and experience; management; scope; and method.

(v) The health consultant refines the scope based on knowledge of similar projects, the scientific literature, the opinions of stakeholders, baseline conditions, and personal experience. 


\section{Figure A3.1: Sample Terms of Reference for a Public Health Specialist} During a Reconnaissance Mission

\section{Introduction}

1. Briefly outline the planned infrastructure to be developed by the project and its location. Identify communities that may be affected by the project. Identify any infrastructure in the vicinity or region that may contribute to cumulative effects.

Example:

The proposed _ (insert name) project will involve construction of _ (insert number of units) _ (insert capacity, e.g., how many $M W$ or how many $\mathrm{m}^{3} /$ day, etc.) _ (insert project component, e.g.,: highway, railway, power plant, water supply, etc.) at _(insert location). The nearest communities are __and___ (insert names of communities, which may be more than two) which are __and __ (insert distance in $\mathrm{km}$ ) respectively from the project site. Studies (identify which studies, e.g., air dispersion modeling, water quality modeling, noise/vibration studies, stakeholder consultations, etc.) have shown that the project's area of influence extends for __ (insert linear or area distance in $\mathrm{km}$ or $\mathrm{km}^{2}$ ). The existing _ (insert name of existing infrastructure that may contribute to cumulative or synergistic effects) is located _ (insert distance in $\mathrm{km}$ ) to the __ (insert direction, e.g., north, south, east, or west, etc.).

2. Identify the project's relevance to any natural resources of significance.

Example:

The project is located _ (insert distance in $\mathrm{km}$ ) to the _ (insert direction, e.g., north, south, east, or west, etc.) of the _ (insert name or description of the natural resource of concern, eg: reservoir, wetland, estuary, coastal zone, etc.). This sensitive resource is used for __ (insert uses, which may be more than one, e.g., source of drinking-water or irrigation, flood control, recreation, commercial or artisanal fishing, tourism, etc.).

3. Identify any infrastructure currently existing at the project site.

Example:

Currently, there exists on site _ (insert number) _ (insert capacity) _ (insert type of infrastructure, e.g., power plant, treatment plant, transport hub, marina, etc.).

4. Provide background information on project categorization under ADB's Safeguard Policy Statement (2009), highlight any known environmental concerns that may be relevant for the health impact assessment (HIA), and identify any critical gaps in knowledge.

continued on next page 
Figure A3.1 continued

Example:

This project falls under ADB's project Category $A$ for environment and is required by its Safeguard Policy Statement (2009) to carry out an environmental impact assessment (EIA). Based on __ (mention type or types of existing studies, e.g., air quality or water quality modeling, noise/vibration studies, public consultations, etc.) it is projected that __ (describe project impact, e.g., air quality or water quality standards may be exceeded, an area of wetlands or coastal zone may be destroyed, etc.). It was seen through _ (identify the study or consultation) that information was insufficient on _ (identify the area of deficiency, e.g., baseline data, particular stakeholders' concerns, cumulative or synergistic effects, etc.).

\section{Scope of Work}

1. Provide a broad overview of the work to be performed.

Example:

The public health specialist will:

a) identify how the proposed project relates to national priorities as identified in the national public health policies and plans, ADB's country health analysis, and sectors identified as priorities in ADB's country partnership strategy;

b) help the team leader in preparing a preliminary assessment of whether the community health benefits of the project will flow primarily to poor/non-poor consumers and whether any poor or vulnerable groups could be excluded from the health benefits;

c) help the team leader in determining the scale and scope for further detailed community health and safety analysis to make the project design more health and safety enhancing for vulnerable groups. This analysis is likely to include consideration of related institutional or capacity issues and the need to prepare health action or mitigation plans and other related measures;

d) identify suitable nongovernment organizations (NGOs) and/or community-based organizations (CBOs) with public health expertise to consult with on the proposed project, and explore possibilities to involve NGOs/CBOs in preparation of the project;

e) help the team leader assess whether the project requires construction or rehabilitation of major works that could have community health impacts. If relevant, assess the need for further analysis during the design phase of the likely health impact of the location, project type and project design options;

f) help the team leader identify whether the project will be in, or pass through, areas of significant Indigenous Peoples settlements. If relevant, prepare an overview of the community health status for these settlements, anticipate the health impacts of the project on Indigenous People, and identify the potential need during the design phase for further analysis and preparation of a public health management plan that safeguards and enhances the health of Indigenous Peoples. 
Figure A3.1 continued

2. Identify the level of effort required by the consultant.

Example:

Inputs required will be __ (insert quantity) person-months for the consultant.

\section{Detailed Tasks and Activities}

1. Describe the detailed work of the consultant.

Example:

The public health specialist will:

a) help the team leader (a) identify key stakeholders, including both men and women from poor and vulnerable groups, and their project-related health concerns; (b) suggest possible strategies to address the health concerns of these stakeholders; (c) identify health determinants affecting project health and safety risks; and (d) contribute to the initial stakeholder analysis and initial participation plan;

b) apply the $A D B$ operational definition of health for use in infrastructure development. Address, in a balanced manner, the five major categories of health outcomes and the three major categories of health determinants;

c) prepare an initial analysis of the health impact of the project by gender and identify gender-specific health baseline data and potential mitigation measures;

d) assess whether, and in what way, the community health and safety of any other vulnerable groups could be better or worse off because of the development project, and identify any need for mitigation and enhancement measures;

e) identify any other potential health risks associated with the project, due to changes in the determinants of health, and assess the need for further analysis of these risks and preparation of appropriate mitigation plans or other measures during the design phase.

\section{Qualifications}

1. Describe the minimum qualifications required of the consultant. Depending on the complexity of the work, an HIA may require an international or a locally recruited consultant. In some cases, it may be advantageous to engage the services of both an international expert and a local consultant to work together as a team.

Example:

The international consultant must have a professional qualification in public health or a closely related field, must be an internationally recognized HIA expert or nationally recognized expert in his or her own country, must have at least 5 years' practical experience 
Figure A3.1 continued

developing HIA's as team leader or team member, and must be familiar with state-of-the art HIA practices.

Or:

The national consultant must have health-related education such as a degree in public health or a closely related field, must be familiar with the health impacts of infrastructure projects, must have fluency in the national language and working-level capacity in English, and must have an established network of contacts in the health sector within the project's area of influence and at national level.

Figure A3.2: Sample Terms of Reference for a Public Health Specialist During a Project Design Mission

\section{Introduction}

1. Briefly outline the planned infrastructure to be developed by the project and its location. Identify communities that may be affected by the project. Identify any infrastructure in the vicinity or region that may contribute to cumulative effects.

Example:

The proposed _ (insert name) project will involve construction of __ (insert number of units) __ (insert capacity, e.g., how many $M W$ or how many $\mathrm{m}^{3} /$ day, etc.) _ (insert project component, e.g.,: highway, railway, power plant, water supply, etc.) at _(insert location). The nearest communities are __and__ (insert names of communities, which may be more than two) which are _ and _ (insert distance in $\mathrm{km}$ ) respectively from the project site. Studies (identify which studies, e.g., air dispersion modeling, water quality modeling, noise/vibration studies, stakeholder consultations, etc.) have shown that the project's area of influence extends for _ _ (insert linear or area distance in $\mathrm{km}$ or $\mathrm{km}^{2}$ ). The existing _ (insert name of existing infrastructure that may contribute to cumulative or synergistic effects) is located _ (insert distance in $\mathrm{km}$ ) to the _ (insert direction, e.g., north, south, east, or west, etc.).

2. Identify the project's relevance to any natural resources of significance.

Example:

The project is located _ (insert distance in $\mathrm{km}$ ) to the _ (insert direction, e.g., north, south, east, or west, etc.) of the _ (insert name or description of the natural resource of concern, eg: reservoir, wetland, estuary, coastal zone, etc.). This sensitive resource is used for __ (insert uses, which may be more than one, e.g., source of drinking-water or irrigation, flood control, recreation, commercial or artisanal fishing, tourism, etc.).

3. Identify any infrastructure currently existing at the project site. 
Figure A3.2 continued

\section{Example:}

Currently, there exists on site _ (insert number) _ (insert capacity) _ (insert type of infrastructure, e.g., power plant, treatment plant, transport hub, marina, etc.).

4. Provide background information on project categorization under ADB's Safeguard Policy Statement (2009), highlight any known environmental concerns that may be relevant for the health impact assessment (HIA), and identify any critical gaps in knowledge.

Example:

This project falls under ADB's project Category A for environment and is required by its Safeguard Policy Statement (2009) to carry out an environmental impact assessment. Based on __ (mention type or types of existing studies, e.g., air quality or water quality modeling, noise/vibration studies, public consultations, etc.) it is projected that _ (describe project impact, e.g., air quality or water quality standards may be exceeded, an area of wetlands or coastal zone may be destroyed, etc.). It was seen through _ (identify the study or consultation) that information was insufficient on _ (identify the area of deficiency, e.g., baseline data, particular stakeholders' concerns, cumulative or synergistic effects, etc.).

\section{Scope of Work}

1. Provide a broad overview of the work to be performed.

Example:

The public health specialist will:

a) Identify the different community groups that are likely to be affected by the project and their health characteristics.

b) Separate the health issues associated with occupational (worker) health and safety from the health issues associated with community health.

2. Identify the level of effort required by the consultant.

Example:

Inputs required will be __ (insert quantity) person-months for the consultant.

\section{Detailed Tasks and Activities}

1. Describe the detailed work of the consultant.

Example:

The public health specialist will: 
Figure A3.2 continued

a) Apply the $A D B$ operational definition of health for use in infrastructure development. Address, in a balanced manner, the five major categories of health outcomes and the three major categories of health determinants.

b) Identify health targets and indicators and mechanisms for monitoring the health impacts of the project, to be included in the design and monitoring framework and project performance management system, and mechanisms for collecting relevant disaggregated community health data.

c) Identify potential changes to the determinants of health from the reports of other subject specialists, including environmental specialists.

d) Assess the capacity of the proposed executing and implementing agencies to deliver healthcare services to the different community groups, and implement mitigation plans, and, where appropriate, make recommendations to strengthen their capacity through the development project.

e) Verify that an appropriate occupational health and safety management plan for the construction and operation workforces is included in the project design.

f) Help the team leader address health risks, opportunities and vulnerabilities within the project; identify appropriate public and community health relevant legislation, policy, and regulations; and draft appropriate assurances to ensure the protection of vulnerable groups during the implementation of the project.

\section{Qualifications}

1. Describe the minimum qualifications required of the consultant. Depending on the complexity of the work, an HIA may require an international or a locally recruited consultant. In some cases, it may be advantageous to engage the services of both an international expert and a local consultant to work together as a team.

Example:

The international consultant must have a professional qualification in public health or a closely related field, must be an internationally recognized HIA expert or nationally recognized expert in his or her own country, must have at least 5 years' practical experience developing HIA's as team leader or team member, and must be familiar with state-of-the art HIA practices.

Or:

The national consultant must have health-related education such as a degree in public health or a closely related field, must be familiar with the health impacts of infrastructure projects, must have fluency in the national language and working-level capacity in English, and must have an established network of contacts in the health sector within the project's area of influence and at national level. 
Figure A3.3: Sample Terms of Reference for a Public Health Specialist for a Rapid Health Impact Assessment

\section{Introduction}

1. Briefly outline the planned infrastructure to be developed by the project and its location. Identify communities that may be affected by the project. Identify any infrastructure in the vicinity or region that may contribute to cumulative effects.

Example:

The proposed _ (insert name) project will involve construction of __ (insert number of units) _ (insert capacity, e.g., how many $M W$ or how many $\mathrm{m}^{3} /$ day, etc.) _ (insert project component, e.g.,: highway, railway, power plant, water supply, etc.) at _(insert location). The nearest communities are __ and __ (insert names of communities, which may be more than two) which are __ and __ (insert distance in $\mathrm{km}$ ) respectively from the project site. Studies (identify which studies, e.g., air dispersion modeling, water quality modeling, noise/vibration studies, stakeholder consultations, etc.) have shown that the project's area of influence extends for __ (insert linear or area distance in $\mathrm{km}$ or $\mathrm{km}^{2}$ ). The existing _ (insert name of existing infrastructure that may contribute to cumulative or synergistic effects) is located _ (insert distance in $\mathrm{km}$ ) to the __ (insert direction, e.g., north, south, east, or west, etc.).

2. Identify the project's relevance to any natural resources of significance.

Example:

The project is located __ (insert distance in $\mathrm{km}$ ) to the _ (insert direction, e.g., north, south, east, or west, etc.) of the _ (insert name or description of the natural resource of concern, e.g.,: reservoir, wetland, estuary, coastal zone, etc.). This sensitive resource is used for (insert uses, which may be more than one, e.g., source of drinking-water or irrigation, flood control, recreation, commercial or artisanal fishing, tourism, etc.).

3. Identify any infrastructure currently existing at the project site.

Example:

Currently, there exists on site _ (insert number) _ (insert capacity) _ (insert type of infrastructure, e.g., power plant, treatment plant, transport hub, marina, etc.).

4. Provide background information on project categorization under ADB's Safeguard Policy Statement (2009), highlight any known environmental concerns that may be relevant for the health impact assessment (HIA), and identify any critical gaps in knowledge.

Example:

This project falls under ADB's project Category A for environment and is required by its Safeguard Policy Statement (2009) to carry out an environmental impact assessment. Based on __ (mention type or types of existing studies, e.g., air quality or water quality modeling, 
Figure A3.3 continued

noise/vibration studies, public consultations, etc.) it is projected that _ (describe project impact, e.g., air quality or water quality standards may be exceeded, an area of wetlands or coastal zone may be destroyed, etc.). It was seen through _ (identify the study or consultation) that information was insufficient on _ (identify the area of deficiency, e.g., baseline data, particular stakeholders' concerns, cumulative or synergistic effects, etc.).

\section{Scope of Work}

1. Provide a broad overview of the work to be performed.

Example:

The public health specialist will:

a) Review the rapid scope and suggest changes.

b) Identify the different community groups that are likely to be affected by the project and their health characteristics.

c) Separate the health issues associated with occupational (worker) health and safety from the health issues associated with community health.

2. Identify the level of effort required by the consultant.

Example:

Inputs required will be __ (insert quantity) person-months for the consultant.

\section{Detailed Tasks and Activities}

1. Describe the detailed work of the consultant.

Example:

The public health specialist will:

a) Collect secondary data regarding the current health status and the associated health determinants for project-affected communities from government, academic, and nongovernment organization sources, and from key informant interview. Triangulate. Assess the accuracy of routinely collected health data at local level. Assess the capabilities and capacity of the current health services. Assess the current health needs of the existing communities. Identify gaps. Propose a plan for primary data collection, if necessary, that is statistically and ethically sound, and achievable in the time available.

b) Apply the $A D B$ operational definition of health for use in infrastructure development. Address, in a balanced manner, the five major categories of health outcomes and the three major categories of health determinants. 
Figure A3.3 continued

c) Identify health targets and indicators and mechanisms for monitoring the health impacts of the project, to be included in the DMF and project performance management system, and mechanisms for collecting relevant disaggregated community health data.

d) Identify potential changes to the determinants of health from the reports of other subject specialists, including environmental specialists.

e) Assess the capacity of the proposed executing and implementing agencies to deliver healthcare services to the different community groups, and implement mitigation plans, and, where appropriate, make recommendations to strengthen their capacity through the development project.

f) Verify that an appropriate occupational health and safety management plan for the construction and operation workforces is included in the project design.

g) Develop models for each disease group which estimates the cost of such diseases accrued through out-of pocket expenditures for treatment and healthy life years lost because of disease (Disability Adjusted Life Years, DALYs) (footnote 34).

h) Prepare justified recommendations for enhancing health opportunities and mitigating health risks based on prioritization of health issues.

\section{Qualifications}

1. Describe the minimum qualifications required of the consultant. Depending on the complexity of the work, an HIA may require an international or a locally recruited consultant. In some cases, it may be advantageous to engage the services of both an international expert and a local consultant to work together as a team.

Example:

The international consultant must have a professional qualification in public health or a closely related field, must be an internationally recognized HIA expert or nationally recognized expert in his or her own country, must have at least five-years practical experience developing HIA's as team leader or team member, and must be familiar with state-of-the art HIA practices.

Or:

The national consultant must have health-related education such as a degree in public health or a closely related field, must be familiar with the health impacts of infrastructure projects, must have fluency in the national language and working-level capacity in English, and must have an established network of contacts in the health sector within the project's area of influence and at national level. 
Figure A3.4: Sample Terms of Reference for A Public Health Specialist During Feasibility Study

\section{Introduction}

1. Briefly outline the planned infrastructure to be developed by the project and its location. Identify communities that may be affected by the project. Identify any infrastructure in the vicinity or region that may contribute to cumulative effects.

\section{Example:}

The proposed _ (insert name) project will involve construction of __ (insert number of units) _ (insert capacity, eg how many $M W$ or how many $m^{3} /$ day, etc.) _ (insert project component, eg: highway, railway, power plant, water supply, etc.) at _ (insert location). The nearest communities are __and _ (insert names of communities, which may be more than two) which are _ and _ (insert distance in $\mathrm{km}$ ) respectively from the project site. Studies (identify which studies, e.g., air dispersion modeling, water quality modeling, noise/vibration studies, stakeholder consultations, etc.) have shown that the project's area of influence extends for __ (insert linear or area distance in $\mathrm{km}$ or $\mathrm{km}^{2}$ ). The existing _ (insert name of existing infrastructure that may contribute to cumulative or synergistic effects) is located __ (insert distance in $\mathrm{km}$ ) to the __ (insert direction, e.g., north, south, east, or west, etc.).

2. Identify the project's relevance to any natural resources of significance.

Example:

The project is located _ (insert distance in $\mathrm{km}$ ) to the _ (insert direction, e.g., north, south, east, or west, etc.) of the _- (insert name or description of the natural resource of concern, eg: reservoir, wetland, estuary, coastal zone, etc.). This sensitive resource is used for (insert uses, which may be more than one, e.g., source of drinking-water or irrigation, flood control, recreation, commercial or artisanal fishing, tourism, etc.).

3. Identify any infrastructure currently existing at the project site.

Example:

Currently, there exists on site _ (insert number) _ (insert capacity) _ (insert type of infrastructure, e.g., power plant, treatment plant, transport hub, marina, etc.).

4. Provide background information on project categorization under ADB's Safeguard Policy Statement (2009), highlight any known environmental concerns that may be relevant for the health impact assessment (HIA), and identify any critical gaps in knowledge.

Example:

This project falls under ADB's project Category A for environment and is required by its Safeguard Policy Statement (2009) to carry out an environmental impact assessment (EIA). 
Figure A3.4 continued

Based on _ (mention type or types of existing studies, e.g., air quality or water quality modeling, noise/vibration studies, public consultations, etc.) it is projected that _ (describe project impact, e.g., air quality or water quality standards may be exceeded, an area of wetlands or coastal zone may be destroyed, etc.). It was seen through _ (identify the study or consultation) that information was insufficient on _ (identify the area of deficiency, e.g., baseline data, particular stakeholders' concerns, cumulative or synergistic effects, etc.)

\section{Scope of Work}

1. Provide a broad overview of the work to be performed.

Example:

The HIA work will include:

(i) Review of existing documentation including _ _ (insert specific existing documents, eg. draft EIA) and other related documents and studies;

(ii) Improve _ (identify existing work in need of improvement, e.g., baseline studies, risk assessments, stakeholder consultations, etc.);

(iii) (Assess health and safety risks (or, improve existing risk assessments) to workers and to communities with regard to project impacts (alone and cumulatively) during construction and operation phases;

(iv) Develop recommendations for mitigation measures;

(v) Develop a public health monitoring plan (PHMP) to be integrated into the environmental monitoring plan (EMP) to monitor actual health impacts during construction and operation phases.

Impacts should be assessed for the different population groups including any vulnerable groups, downwind and downstream communities, and communities whose livelihood would be affected by the project.

2. Identify the level of effort required by the consultant.

Example:

Inputs required will be __ (insert quantity) person-months for the consultant.

\section{Detailed Tasks and Activities}

1. Describe the detailed work of the consultant. 
Figure A3.4 continued

Example:

The detailed work of the consultant will include, but not be limited to the following:

a) From review of draft EIA and all other existing relevant documents and studies, define the likely factors that influence health determinants and health outcomes (health impact pathways); as a baseline study, determine if the factors are related to the project's health and safety impacts/risks or are external to the project.

b) Review the draft EIA report, Environmental Audit Report and Corrective Action Plan, Environmental Management Plan and other associated reports related to air and water quality assessment and summarize the health-relevant information about the project's influence on the health determinants and health outcomes. Summarize their findings and recommendations and identify and health impact gaps which will need to be addressed by the HIA.

c) Collect, analyze, and synthesize secondary community health information on the health status of workers and communities in the project's area of influence to understand the existing key health determinants. Collect adequate primary health baseline data from workers and communities with the project's area of influence to fill any gaps in the secondary data. Data should be disaggregated to the project and pre-existing infrastructure and other community members to the extent practical. Describe the baseline health status of workers and communities in worker and community health profiles using secondary and primary data.

d) Engage local health authorities and communities, including poor and vulnerable groups, in collecting baseline data and to help identify project and other health concerns within the project's area of influence.

e) Assess the existing health determinants and outcomes that may be cumulatively affected by the project, as reference for any before-and-after comparisons of changes in health determinants.

f) Assess the health and safety impacts/risks of the project to the existing communities within the project's area of influence. The assessment will include an analysis of both project and cumulative health and safety impacts/risks covering both geographic and temporal dimensions, beyond the project area and continuing into the operation phase.

g) Identify any additional mitigation that may be needed, beyond that already proposed in the draft EIA.

h) Identify appropriate and feasible community health indicators to monitor community health impacts, especially among vulnerable populations, in the form of a PHMP. The PHMP should be linked to the EMP for implementation during construction and operation. 
Figure A3.4 continued

\section{Qualifications}

1. Describe the minimum qualifications required of the consultant. Depending on the complexity of the work, an HIA may require an international or a locally recruited consultant. In some cases, it may be advantageous to engage the services of both an international expert and a local consultant to work together as a team.

Example:

The international consultant must have a professional qualification in public health or a closely related field, must be an internationally recognized HIA expert or nationally recognized expert in his or her own country, must have at least five-years practical experience developing HIA's as team leader or team member, and must be familiar with state-of-the art HIA practices.

Or:

The national consultant must have health-related education such as a degree in public health or a closely related field, must be familiar with the health impacts of infrastructure projects, must have fluency in the national language and working-level capacity in English, and must have an established network of contacts in the health sector within the project's area of influence and at national level. 


\section{APPENDIX 4 \\ Construction Safety Check List}

\begin{tabular}{|c|c|c|}
\hline Requirements & $\begin{array}{l}\text { Compliance } \\
\text { Status (Y/N) }\end{array}$ & Actions Done \\
\hline \multicolumn{3}{|l|}{ I. ROLES, RESPONSIBILITIES AND RESOURCES } \\
\hline \multicolumn{3}{|l|}{$\begin{array}{l}\text { Roles and responsibilities of each person in the organization } \\
\text { regarding health and safety at the construction site including } \\
\text { subcontractors are clearly documented. }\end{array}$} \\
\hline \multicolumn{3}{|l|}{$\begin{array}{l}\text { Competent person/s has/have been identified who shall have } \\
\text { the responsibility to ensure that health and safety Standards } \\
\text { are consistently being implemented. The number of competent } \\
\text { persons shall follow local regulations. }\end{array}$} \\
\hline \multicolumn{3}{|l|}{$\begin{array}{l}\text { A functional Health and Safety Committee with workers } \\
\text { representation has been established. }\end{array}$} \\
\hline \multicolumn{3}{|l|}{$\begin{array}{l}\text { Provisions for Health and Safety Standards implementations are } \\
\text { part of the project budget. }\end{array}$} \\
\hline \multicolumn{3}{|l|}{ II. CONSTRUCTION ACTIVITY RISK ASSESSMENTS } \\
\hline \multicolumn{3}{|l|}{$\begin{array}{l}\text { Before the start of the project and any additional activities, } \\
\text { a risk assessment of activities has been conducted and } \\
\text { countermeasures have been identified. This assessment is led } \\
\text { by the identified competent person with subject matter experts } \\
\text { within the project. }\end{array}$} \\
\hline \multicolumn{3}{|l|}{$\begin{array}{l}\text { No high-risk activity is done if countermeasures are not fully } \\
\text { in-place. }\end{array}$} \\
\hline \multicolumn{3}{|l|}{$\begin{array}{l}\text { The risk assessment has considered other variables such as } \\
\text { weather, time of the day, other activities that may be happening } \\
\text { simultaneously, competence of available workers and others. }\end{array}$} \\
\hline \multicolumn{3}{|l|}{$\begin{array}{l}\text { The results of the risk assessment are cascaded to all concerned } \\
\text { including the countermeasures and effect if countermeasure is } \\
\text { not implemented or followed. }\end{array}$} \\
\hline \multicolumn{3}{|l|}{ III. PROCEDURES, RECORDS, AND DOCUMENTATIONS } \\
\hline \multicolumn{3}{|l|}{$\begin{array}{l}\text { A health and safety manual is available and accessible to all } \\
\text { workers preferably in the local language. }\end{array}$} \\
\hline \multicolumn{3}{|l|}{$\begin{array}{l}\text { Detailed procedures are available especially for high risk } \\
\text { activities such as heavy equipment operation, excavation, work } \\
\text { at heights, hot works, confined space entry, electrical works, and } \\
\text { others that may be identified in the Risk Assessment. }\end{array}$} \\
\hline \multicolumn{3}{|l|}{$\begin{array}{l}\text { Records of inspections of job site, tools, equipment, personal } \\
\text { protective equipment, emergency response equipment and } \\
\text { others are available. }\end{array}$} \\
\hline $\begin{array}{l}\text { Training records including attendance sheets of toolbox } \\
\text { meetings are available. }\end{array}$ & & \\
\hline
\end{tabular}


Appendix Table continued

\begin{tabular}{|c|c|c|}
\hline Requirements & $\begin{array}{l}\text { Compliance } \\
\text { Status (Y/N) }\end{array}$ & Actions Done \\
\hline \multicolumn{3}{|l|}{ Medical records of workers are available and secured. } \\
\hline \multicolumn{3}{|l|}{ Incidents and incident investigation records are available. } \\
\hline \multicolumn{3}{|l|}{ IV. TRAINING, INFORMATION, AND AWARENESS } \\
\hline \multicolumn{3}{|l|}{$\begin{array}{l}\text { All workers have received appropriate training corresponding to } \\
\text { their job assignments and as required by local regulations. }\end{array}$} \\
\hline \multicolumn{3}{|l|}{$\begin{array}{l}\text { All workers have been informed of potential health and safety } \\
\text { risks which they may be exposed in the workplace. }\end{array}$} \\
\hline \multicolumn{3}{|l|}{$\begin{array}{l}\text { All workers have received appropriate instructions and } \\
\text { training on how to do their work safely and measures to protect } \\
\text { themselves against the hazards in the workplace. }\end{array}$} \\
\hline \multicolumn{3}{|l|}{$\begin{array}{l}\text { Health and safety signages are available in the job site to make } \\
\text { workers and visitors aware of hazards and procedures. The } \\
\text { format of which should follow standards of the American } \\
\text { National Standards Institute or local regulations. }\end{array}$} \\
\hline \multicolumn{3}{|l|}{$\begin{array}{l}\text { Restricted and high-risk areas are properly identified and } \\
\text { appropriate signages are installed to warn workers. }\end{array}$} \\
\hline \multicolumn{3}{|l|}{$\begin{array}{l}\text { Bulletin Boards are available and display the health and safety } \\
\text { performance of the project. }\end{array}$} \\
\hline \multicolumn{3}{|l|}{ V. WELFARE } \\
\hline \multicolumn{3}{|l|}{$\begin{array}{l}\text { Workers have undergone a medical check and are fit for their job } \\
\text { assignment. }\end{array}$} \\
\hline \multicolumn{3}{|l|}{$\begin{array}{l}\text { Workers have access to adequate supply of potable water. } \\
\text { The water must be tested monthly or as prescribed by local } \\
\text { regulations. }\end{array}$} \\
\hline \multicolumn{3}{|l|}{$\begin{array}{l}\text { Depending on the number of workers, the following have been } \\
\text { provided: } \\
\text { - Sanitary and washing facilities; } \\
\text { - Facilities for changing and drying of clothing; } \\
\text { - Accommodation for taking meals and for taking shelter during } \\
\text { interruption of work due to adverse weather conditions. }\end{array}$} \\
\hline \multicolumn{3}{|l|}{ Men and women have separate sanitary and washing facilities. } \\
\hline \multicolumn{3}{|l|}{$\begin{array}{l}\text { There is adequate first aid or medical facilities and personnel } \\
\text { onsite at all times, the number of which shall follow local } \\
\text { regulations. }\end{array}$} \\
\hline \multicolumn{3}{|l|}{$\begin{array}{l}\text { Living accommodations for workers staying onsite are of good } \\
\text { construction, clean, secure, and away from danger. It contains } \\
\text { basic necessities such as bed, pillow, beddings, blankets, adequate } \\
\text { lighting, and sewerage. }\end{array}$} \\
\hline \multicolumn{3}{|l|}{ VI. PERSONAL PROTECTIVE EQUIPMENT } \\
\hline \multicolumn{3}{|l|}{$\begin{array}{l}\text { Appropriate personal protective equipment is provided without } \\
\text { additional costs to the workers. }\end{array}$} \\
\hline $\begin{array}{l}\text { Workers are trained on how to properly use and care for the } \\
\text { personal protective equipment. }\end{array}$ & & \\
\hline
\end{tabular}


Appendix Table continued

\begin{tabular}{|c|c|c|}
\hline Requirements & $\begin{array}{l}\text { Compliance } \\
\text { Status (Y/N) }\end{array}$ & Actions Done \\
\hline \multicolumn{3}{|l|}{$\begin{array}{l}\text { Protective equipment shall comply with standards set forth by } \\
\text { the local authority. In the absence of a local standard, protective } \\
\text { equipment shall follow the standards set forth by the American } \\
\text { National Standards Institute. }\end{array}$} \\
\hline \multicolumn{3}{|l|}{$\begin{array}{l}\text { Personal protective equipment shall be regularly inspected and } \\
\text { replaced when no longer in good condition. }\end{array}$} \\
\hline \multicolumn{3}{|l|}{ VII. WORK AT HEIGHTS } \\
\hline \multicolumn{3}{|l|}{$\begin{array}{l}\text { Adequate guards are provided such as railings and toeboards } \\
\text { to guard against the fall of workers, objects and materials for } \\
\text { working platforms. These guards shall follow the local standards } \\
\text { and regulations. }\end{array}$} \\
\hline \multicolumn{3}{|l|}{$\begin{array}{l}\text { For activities wherein railings cannot be installed, a personal } \\
\text { fall arrest system comprised of anchorage, safety harness, shock } \\
\text { absorber and double lanyard is available. }\end{array}$} \\
\hline \multicolumn{3}{|l|}{$\begin{array}{l}\text { Ladders and scaffolds to be used must be of appropriate } \\
\text { construction and good condition. }\end{array}$} \\
\hline \multicolumn{3}{|l|}{$\begin{array}{l}\text { The height and position of the ladder is appropriate for its } \\
\text { intended use. The worker does not stand on the top rung and the } \\
\text { body does not extend beyond the ladder. }\end{array}$} \\
\hline \multicolumn{3}{|l|}{$\begin{array}{l}\text { Scaffolds are erected and dismantled only by competent persons } \\
\text { as defined by local regulation or in its absence as defined by the } \\
\text { company's Health and Safety Manual. }\end{array}$} \\
\hline \multicolumn{3}{|l|}{ Scaffolds are inspected daily before use by a competent person. } \\
\hline \multicolumn{3}{|l|}{$\begin{array}{l}\text { Scaffolds are stable and properly anchored. In case of uneven or } \\
\text { slippery floor, mudsills, and base jacks are used. }\end{array}$} \\
\hline \multicolumn{3}{|l|}{ Scaffold designs conform to local regulations. } \\
\hline \multicolumn{3}{|l|}{ In case of inclement weather, work at heights are not allowed. } \\
\hline \multicolumn{3}{|l|}{$\begin{array}{l}\text { There is a system for rescue in case a worker falls and is } \\
\text { suspended by the harness. }\end{array}$} \\
\hline \multicolumn{3}{|l|}{ VIII. HOT WORKS } \\
\hline \multicolumn{3}{|l|}{$\begin{array}{l}\text { All involved in any hot work have been properly trained } \\
\text { including firefighting. }\end{array}$} \\
\hline \multicolumn{3}{|l|}{$\begin{array}{l}\text { All equipment to be used for hot work are in good condition and } \\
\text { inspected prior to use. Welding machines are grounded prior to } \\
\text { use and gas hoses do not have leaks. }\end{array}$} \\
\hline \multicolumn{3}{|l|}{ A permitting system is in place to control hot works. } \\
\hline \multicolumn{3}{|l|}{$\begin{array}{l}\text { All workers involved in hot works have the appropriate Personal } \\
\text { Protective Equipment such as appropriate eye protection, } \\
\text { welding jackets, welding gloves and safety shoes. Other personal } \\
\text { protective equipment are considered when there are other } \\
\text { special risks such as hot works in confined space. Appropriate } \\
\text { respiratory protection is being used in case metals to be } \\
\text { processed contain toxic heavy metals such as mercury, zinc, } \\
\text { cadmium, lead or chromium. }\end{array}$} \\
\hline $\begin{array}{l}\text { A flashback arrestor or check valve is installed on all fuel gas and } \\
\text { oxygen regulators. }\end{array}$ & & \\
\hline
\end{tabular}




\section{Appendix Table continued}

\begin{tabular}{|c|c|c|}
\hline Requirements & $\begin{array}{l}\text { Compliance } \\
\text { Status (Y/N) }\end{array}$ & Actions Done \\
\hline \multicolumn{3}{|l|}{$\begin{array}{l}\text { A competent fire watchman has been designated for every hot } \\
\text { work site whose responsibility is to ensure that there will be no } \\
\text { reignition. }\end{array}$} \\
\hline \multicolumn{3}{|l|}{$\begin{array}{l}\text { Hot work area is clean from flammable and combustible } \\
\text { materials within an 11-meter radius. Fire prevention measures } \\
\text { are in place. }\end{array}$} \\
\hline \multicolumn{3}{|l|}{ Hot work area is properly ventilated. } \\
\hline \multicolumn{3}{|l|}{$\begin{array}{l}\text { Hot work area is properly isolated either by physical isolation or } \\
\text { by use of noncombustible material such as fire blankets to avoid } \\
\text { sparks to fly out from the hot work area. }\end{array}$} \\
\hline \multicolumn{3}{|l|}{$\begin{array}{l}\text { Compressed gases for hot work are properly secured and stored. } \\
\text { Unused compressed gases must have caps. Tanks are properly } \\
\text { labeled and have no leaks. }\end{array}$} \\
\hline \multicolumn{3}{|l|}{$\begin{array}{l}\text { Appropriate and adequate firefighting equipment is available in } \\
\text { the hot work area. }\end{array}$} \\
\hline \multicolumn{3}{|l|}{ IX. CHEMICAL MANAGEMENT } \\
\hline \multicolumn{3}{|l|}{$\begin{array}{l}\text { All chemical handlers have been informed of the hazards of } \\
\text { the chemicals they use including the necessary precautions to } \\
\text { protect them from these hazards. }\end{array}$} \\
\hline \multicolumn{3}{|l|}{ Safety data sheets are available at point of use and storage. } \\
\hline \multicolumn{3}{|l|}{$\begin{array}{l}\text { Regulated chemicals are identified and requirements related to } \\
\text { these as prescribed by local regulations have been complied with. }\end{array}$} \\
\hline \multicolumn{3}{|l|}{$\begin{array}{l}\text { All chemicals are properly stored as required by the safety data } \\
\text { sheets. }\end{array}$} \\
\hline \multicolumn{3}{|l|}{$\begin{array}{l}\text { Appropriate personal protective equipment as required by the } \\
\text { safety data sheets are being used by chemical handlers. }\end{array}$} \\
\hline \multicolumn{3}{|l|}{$\begin{array}{l}\text { Chemical storage areas have been identified, secured against } \\
\text { unauthorized access and have spill prevention and control } \\
\text { mechanisms. }\end{array}$} \\
\hline \multicolumn{3}{|l|}{ Spill response equipment are adequate and accessible. } \\
\hline \multicolumn{3}{|l|}{$\begin{array}{l}\text { All chemicals are placed in appropriate containers and are } \\
\text { properly labeled. }\end{array}$} \\
\hline \multicolumn{3}{|l|}{ Safety signages regarding chemical hazards are posted properly. } \\
\hline \multicolumn{3}{|l|}{$\begin{array}{l}\text { X. EXCAVATION, SHAFTS, EARTHWORKS, UNDERGROUND } \\
\text { WORKS, AND TUNNELS }\end{array}$} \\
\hline \multicolumn{3}{|l|}{$\begin{array}{l}\text { An assessment of the area is made to identify risks such as type of } \\
\text { soil, pockets of gases, water table, and presence of buried utilities } \\
\text { as well as effect of the excavation to the surrounding areas. }\end{array}$} \\
\hline \multicolumn{3}{|l|}{$\begin{array}{l}\text { There is suitable shoring to guard against dislodgement of earth, } \\
\text { rock and materials. }\end{array}$} \\
\hline \multicolumn{3}{|l|}{$\begin{array}{l}\text { Excavated materials are properly stored away from the edge of } \\
\text { excavation. }\end{array}$} \\
\hline \multicolumn{3}{|l|}{ Adequate and safe ingress and egress are provided. } \\
\hline The edge of the excavation site is properly guarded. & & \\
\hline
\end{tabular}


Appendix Table continued

\begin{tabular}{|c|c|c|}
\hline Requirements & $\begin{array}{l}\text { Compliance } \\
\text { Status }(\mathbf{Y} / \mathbf{N})\end{array}$ & Actions Done \\
\hline $\begin{array}{l}\text { Precautions are made to ensure that there is adequate ventilation } \\
\text { for workers. To ensure that the atmosphere is fit for respiration, } \\
\text { the air is tested prior to entry at various points. The following are } \\
\text { tested: oxygen level, carbon monoxide level, carbon dioxide level, } \\
\text { lower explosive limits and upper explosive limits. After entry, } \\
\text { testing must be done in established intervals. }\end{array}$ & & \\
\hline A rescue plan is available in case of emergency. & & \\
\hline XI. PLANT, MACHINERY, EQUIPMENT, AND HAND TOOLS & & \\
\hline $\begin{array}{l}\text { Plant, machinery, and equipment including hand tools both } \\
\text { manual and power driven are in good condition and are being } \\
\text { used appropriately. }\end{array}$ & & \\
\hline $\begin{array}{l}\text { Only workers who have been properly trained are operating/ } \\
\text { using plant, machinery, equipment and tools. }\end{array}$ & & \\
\hline $\begin{array}{l}\text { Machinery and equipment are regularly inspected and examined } \\
\text { by competent persons as prescribed by local regulations. }\end{array}$ & & \\
\hline XII. LIFTING APPLIANCES AND GEARS & & \\
\hline $\begin{array}{l}\text { All lifting appliances and gears are in good working condition. } \\
\text { Lifting appliances and gears are tested at least once a year or as } \\
\text { defined by local regulations and inspected before use. }\end{array}$ & & \\
\hline $\begin{array}{l}\text { Defective lifting appliances and gears are tagged and removed } \\
\text { from use. }\end{array}$ & & \\
\hline $\begin{array}{l}\text { Only trained and authorized personnel are operating lifting } \\
\text { appliances and gears. }\end{array}$ & & \\
\hline $\begin{array}{l}\text { Lifting appliances and gears are being used properly and does not } \\
\text { exceed its capacity. }\end{array}$ & & \\
\hline $\begin{array}{l}\text { A hoisting and rigging plan is made by a competent person prior } \\
\text { to lifting. }\end{array}$ & & \\
\hline XIII. HEAVY EQUIPMENT OPERATION & & \\
\hline $\begin{array}{l}\text { Before the operation of heavy equipment, the site has been } \\
\text { assessed to check whether there is enough space for it to } \\
\text { operate, soil condition is optimal, if there are other high-risk } \\
\text { condition such as presence of electrical cables or proximity to } \\
\text { communities. }\end{array}$ & & \\
\hline $\begin{array}{l}\text { There is a system for managing foot traffic such that dangers for } \\
\text { pedestrians are averted. }\end{array}$ & & \\
\hline $\begin{array}{l}\text { Only properly trained and authorized personnel are allowed to } \\
\text { operate heavy equipment and machinery. }\end{array}$ & & \\
\hline $\begin{array}{l}\text { The appropriate type of heavy equipment is being used for } \\
\text { the job. }\end{array}$ & & \\
\hline $\begin{array}{l}\text { Heavy equipment is in good working condition. All safety devices } \\
\text { such as lights, back-up alarm, seatbelts, mirrors, etc. are in good } \\
\text { working condition. Regular periodic maintenance is being done. } \\
\text { Operators inspect the heavy equipment prior to use. }\end{array}$ & & \\
\hline $\begin{array}{l}\text { Spotters are available and uses clearly understood hand signals } \\
\text { and traffic control devices }\end{array}$ & & \\
\hline Adequate parking space is allotted for heavy equipment. & & \\
\hline
\end{tabular}

continued on next page 


\section{Appendix Table continued}

\begin{tabular}{|c|c|c|}
\hline Requirements & $\begin{array}{l}\text { Compliance } \\
\text { Status (Y/N) }\end{array}$ & Actions Done \\
\hline XIV. HOUSEKEEPING AND WASTE MANAGEMENT & & \\
\hline $\begin{array}{l}\text { Wastes are placed in designated area and collected regularly. } \\
\text { There is no waste accumulation. }\end{array}$ & & \\
\hline $\begin{array}{l}\text { Hazardous wastes are handled, stored, and disposed as per } \\
\text { local regulations. }\end{array}$ & & \\
\hline $\begin{array}{l}\text { Sanitation facilities, lockers, eating areas, wash rooms and } \\
\text { worker housing are kept clean and sanitary. }\end{array}$ & & \\
\hline XV. WORKING WITH COMPRESSED AIR & & \\
\hline $\begin{array}{l}\text { Compressed air is only used for its intended purpose and is not } \\
\text { used for cleaning clothing. }\end{array}$ & & \\
\hline $\begin{array}{l}\text { Compressed air lines have regulators. Pressure should not exceed } \\
30 \text { bars when used for cleaning. }\end{array}$ & & \\
\hline XVI. INCIDENT INVESTIGATION AND REPORTING & & \\
\hline $\begin{array}{l}\text { A system is in place for reporting of incidents (injuries, illnesses, } \\
\text { property damage, and environmental incidents), near misses } \\
\text { and hazards. }\end{array}$ & & \\
\hline $\begin{array}{l}\text { Incidents and near misses are properly investigated. Record of } \\
\text { the investigation is kept and appropriate actions are taken to } \\
\text { avoid recurrence. }\end{array}$ & & \\
\hline XVII. ELECTRICITY AND ELECTRICAL WORKS & & \\
\hline $\begin{array}{l}\text { All electrical equipment must be regularly inspected and } \\
\text { maintained in good working condition. }\end{array}$ & & \\
\hline $\begin{array}{l}\text { Only properly trained and authorized personnel are allowed to } \\
\text { do electrical works. }\end{array}$ & & \\
\hline $\begin{array}{l}\text { Adequate controls and procedures are in place to ascertain the } \\
\text { presence of and to guard workers against electrical hazards. }\end{array}$ & & \\
\hline $\begin{array}{l}\text { All electrical panel are kept clear of any obstruction within } \\
\text { 1-meter radius. }\end{array}$ & & \\
\hline $\begin{array}{l}\text { No worker shall work within } 3 \text { meters of an energized and } \\
\text { exposed electrical line. }\end{array}$ & & \\
\hline $\begin{array}{l}\text { Prior to any electrical work, make sure that the lines are de- } \\
\text { energized and are locked out and tagged out. }\end{array}$ & & \\
\hline $\begin{array}{l}\text { Jewelry and other conductive materials are not worn while doing } \\
\text { electrical work. }\end{array}$ & & \\
\hline $\begin{array}{l}\text { In case a ladder is used, the side rails are of nonconductive } \\
\text { material. }\end{array}$ & & \\
\hline XVIII. EMERGENCY PREPAREDNESS AND RESPONSE & & \\
\hline $\begin{array}{l}\text { All workers are properly trained regarding emergency response } \\
\text { and evacuation procedures. }\end{array}$ & & \\
\hline $\begin{array}{l}\text { A safe assembly area has been identified and all emergency } \\
\text { evacuation routes are kept clear at all times. }\end{array}$ & & \\
\hline $\begin{array}{l}\text { Emergency response equipment are easily accessible, adequate } \\
\text { and in good working condition. }\end{array}$ & & \\
\hline Emergency equipment are kept clear within 1-meter radius. & & \\
\hline
\end{tabular}


Appendix Table continued

\begin{tabular}{|l|l|l|}
\hline Requirements & $\begin{array}{c}\text { Compliance } \\
\text { Status (Y/N) }\end{array}$ & Actions Done \\
\hline $\begin{array}{l}\text { Procedures regarding emergency response are in place and are } \\
\text { regularly tested. Emergency contact numbers are available and } \\
\text { updated including nearest medical facilities, fire station, police } \\
\text { station and others. }\end{array}$ & & \\
\hline XIX. VISITOR MANAGEMENT & & \\
\hline $\begin{array}{l}\text { Only visitors wearing appropriate personal protective equipment } \\
\text { such as safety shoes, hard hat, and high visibility vest is allowed } \\
\text { in the area. Other personal protective equipment required will } \\
\text { depend on the area to be visited. }\end{array}$ & & \\
\hline Visitor pathway and restricted areas are identified. & & \\
\hline Visitor protocols are in place. & & \\
\hline
\end{tabular}




\title{
APPENDIX 5 \\ Evaluation Guide for \\ Health Impact Assessments
}

\section{EVALUATION GUIDE FOR HEALTH IMPACT ASSESSMENTS: \\ Guide for Health Professionals}

\author{
By \\ Jeff Spickett and Dianne Katscherian \\ WHO Collaborating Centre for Environmental Health Impact Assessment \\ School of Public Health \\ Faculty of Health Sciences \\ Curtin University, Western Australia
}

2017

Note: The reprinted material is reproduced exactly as printed and reprinted with permissions of the authors. 


\section{Table of Contents}

Introduction $\quad 3$

$\begin{array}{lr}\text { Objectives } & 3\end{array}$

$\begin{array}{ll}\text { Types of Evaluation } & 4\end{array}$

Evaluation of HIA $\quad 5$

Table 1. Preparation for the HIV Review $\quad 8$

Table 2. The Description of the Proposal 9

Table 3. The Scope of the Assessed Health Impacts 10

Table 4. The Profile of the Community and Its Environment 11

Table 5. Assessment of the Health Impacts/Risk Assessments 12

Table 6. Decision Making and Establishing Conditions 14

$\begin{array}{ll}\text { Appendices } & 15\end{array}$

Appendix 1: The Determinants of Health 16

Appendix 2: Format for Health Risk Assessment Summary 17

Table 7. Health Risk Assessment table 17

$\begin{array}{lr}\text { Bibliography } & 18\end{array}$ 


\section{Introduction}

Environmental Impact Assessment (EIA) has been part of the project approvals process in most countries for many years. This process has been effective in predicting the potential adverse impacts of development projects on the environment. There are welldefined procedures to carry out this function in the government. In some countries, other procedures for impact assessment have also been developed including Strategic and Integrated Assessments. In recent years there has been increasing concern about the positive and negative impacts of development projects on the health and well-being of the community likely to be affected by the development proposals.

The current decision-making processes give some coverage of the biophysical environment (mainly air, water, soil and noise) and many of the standards used have some basis in the effects that these parameters have on human health but there is not sufficient coverage of the wider range of parameters (including social, economic, cultural and equity factors) that impact on the health of the community. In addition the consideration of the negative impacts on communities, the assessment process needs to consider the potential to have positive impacts on human health and well-being. This is an important feature of Health Impact Assessment.

Usually guidance documents on the conduct of EIA or other impact assessment procedures is available in countries. However, as there is increasing interest in the inclusion of health and well-being considerations as part of the process there is a need for some guidance for health officials and others to enable then to adequately evaluate how well health components have been covered.

The document outlines the processes for undertaking HIA as a stand-alone or within an integrated assessment process.

\section{Objectives}

The purpose of the process described in this Evaluation Guide for HIA is to provide guidance to Ministry of Health staff and others on the information needed to be able to evaluate a health impact assessment report conducted by or for proponents as part of the process of gaining approval for a development project. This process may also be of value to those involved in the preparation of the health impact assessment, other government sectors, local government staff, proponents and consultants.

Although the Impact Assessment reports prepared by proponents and consultants may vary in structure and format it is expected that the information provided here will enable users to evaluate how well the HIA identifies, evaluates and sets out control measures to minimise the negative impacts and enhance the positive impacts on human health and well-being of the development project.

This evaluation guide is focused on the health impact assessment component of the report and includes coverage of all aspects (including psycho-social, community and equity) that may affect human health and well-being. 
This evaluation guide is presented in the form of a series of questions that the evaluator needs to consider and provide responses on the effectiveness of the report in addressing the impacts on human health and well-being. Responses could range from good coverage to unsatisfactory or risks unacceptable with more information/evidence needed.

In summary the objectives of this evaluation guide are to:

- Provide guidance on the evaluation of the HIA report

- Enable adequate initial preparation for the review by health professionals

- Ensure that there is a suitable description of the proposed development

- Ensure that there is an appropriate profile of the communities (including vulnerable sections) and their relationship to the proposed development

- Ensure that there is full consideration (coverage and understanding) of the potential health impacts both positive and negative

- Ensure that the risks to health are clearly identified, evaluated and mitigated/ managed

- Ensure that sufficient and appropriate evidence is given to support claims and conclusions.

- Establish appropriate conditions for on going management of risk to health to be set for approval

- Ensure that the quality of the HIA report is of a satisfactory standard

\section{Types of Evaluation}

To enable the effective evaluation of activities data needs to be systematically collected from a range of participants and sources so that the reviewer can:

- Make judgments about the activity's value

- Reflect on what has been undertaken

- Determine if the activity's objectives have been achieved

The World Health Organisation indicates that evaluation processes can be of the following types:

- Process evaluation: Measures the processes that occur while an activity or program is in operation. It includes identifying the participants and the effectiveness of the separate activities of the program.

- Impact evaluation: Measures the immediate effect of a program (particularly its objectives).

- Outcome evaluation: Measures the long-term effects of a program (particularly its goals).

The evaluation processes used in this guide are a form of Impact evaluation and provide a direction for the determination of the potential impacts to health and wellbeing before commencement of the proposed activity. The evaluation process requires review of the data used to determine the benefits and risks to health and their management options 
and assesses them against the standards established by the World Health Organisation, the United States Environmental Protection Agency and other groups and adopted by the specific country. These evaluations should determine if the benefits and risks have been considered appropriately and that the health and well-being of the community is secured.

\section{Evaluation of HIA}

The evaluation process that follows is presented in separate sections to facilitate a logical sequence and recognises that different people may take responsibility for specific sections. Of importance is ensuring that there is sufficient and appropriate evidence throughout the whole report.

The specific components of the evaluation to be considered are:

1. Preparation

2. Project description

3. Scoping

4. Profiling

5. Assessment of health impacts/risk assessment

6. Conditions for approval/Decision making

7. Overall report quality

Additional documents for development, such as policies, position papers, guidance documents, codes of practice etc. that will enable the progression of HIA have been identified (in italics).

Additionally, it is important that the review process makes notes on and provides feedback and comments on the general quality of the report. Issues that should be considered include the:

- Clarity and readability of the report,

- Overall structure,

- Logical format of the approaches used,

- The language and expression, use of illustrations,

- Degree of duplication/unnecessary or irrelevant information.

These will be of particular importance during the public review period to ensure that the community can readily understand the information and outcomes provided.

In order to facilitate the review/evaluation process in a logical sequence, a series of tables are provided to allow to evaluator to work through the evaluation process. 


\section{Table 1}

This table deals with the requirements for establishing the review process and highlights the participants and their roles and responsibilities. The review coordinator would normally be a senior $\mathrm{MOH}$ representative and this person would take prime responsibility for leading the evaluation as well as bringing together the relevant members of the evaluation team who have the required expertise and skills for the specific project under consideration. The coordinator would ensure that the timeframe that meets with other government requirements is set and establishes protocols for communication, collecting necessary documentation and collating the final report.

\section{Table 2}

The HIA/other impact assessment documents should appropriately describe all aspects of relevance to the proposal including the physical environment, the processes quantities and materials to be used by the facility, surrounding land uses and communities and other projects in the neighbourhood. This table outlines the issues of relevance.

\section{Table 3}

The scope of the proposal should include all issues of relevance for the assessment. The determinants of health form a key component and should be as a "checklist" to ensure that all significant potential impacts on health have been considered. It is essential that community consultation and stakeholder involvement have been undertaken and key issues identified are included and addressed in the HIA/other impact assessment document. Additionally, agreements among key stakeholders on processes to be undertaken are clearly outlined.

\section{Table 4}

This table guides the evaluation of community demographics and other relevant living, working and leisure components of the community's activities. It is important to ensure that not only the broader community profile is described and understood but also that potentially vulnerable or disadvantaged groups have been identified and their needs addressed. This information should cross-correlate with the information provided in Table 1 but have a focus that addresses the health and well-being of the community.

The profile included in the HIA should provide an information/data base by which any predicted changes to the health and well-being status of the affected population can be judged, vulnerable sections of the affected population should be clearly identified and include physical social and equity considerations. The information and data in the profile should be about the specific population likely to be affected by the project and its proximity to the proposal. 


\section{Table 5}

This table considers the assessments of the impacts identified in the scoping and community profiling sections.

This section should identify and evaluate the potential impacts on human health and well-being both positive and negative. Most countries have health-based guidelines to be used to reliably assess risks to human health and safety. These standards/guidelines are mainly for exposures to physical, chemical and microbiological hazard exposures in the environmental or occupational settings. WHO and other international agencies also have stands of this type that may be used.

The health impact assessment component should clearly identify the potential hazards, the predicted levels of exposure and a comparison of the predictions against national and/ or international standards or guideline values. Supporting evidence should be provided.

\section{Table 6}

This table completes the assessment process and provides for development of feedback to other assessing sectors. The information in this section of the HIA/other impact assessment should include sufficient detail to enable the reviewer to evaluate the potential effectiveness of risk management options for the impacts on health and wellbeing of the project activities during construction, operation and decommissioning.

At the conclusion of the assessment process there are usually conditions imposed to ensure that the potential adverse impacts are controlled and the positive impacts enhanced as far as reasonably practicable. The conditions should be normally set and administered by the approving bodies including the $\mathrm{MOH}$.

\section{NOTE:}

If any elements for each of the tables are not included in the document or have deficiencies, there may be a requirement to request further information or evidence that was used to support their statements from the proponent. 


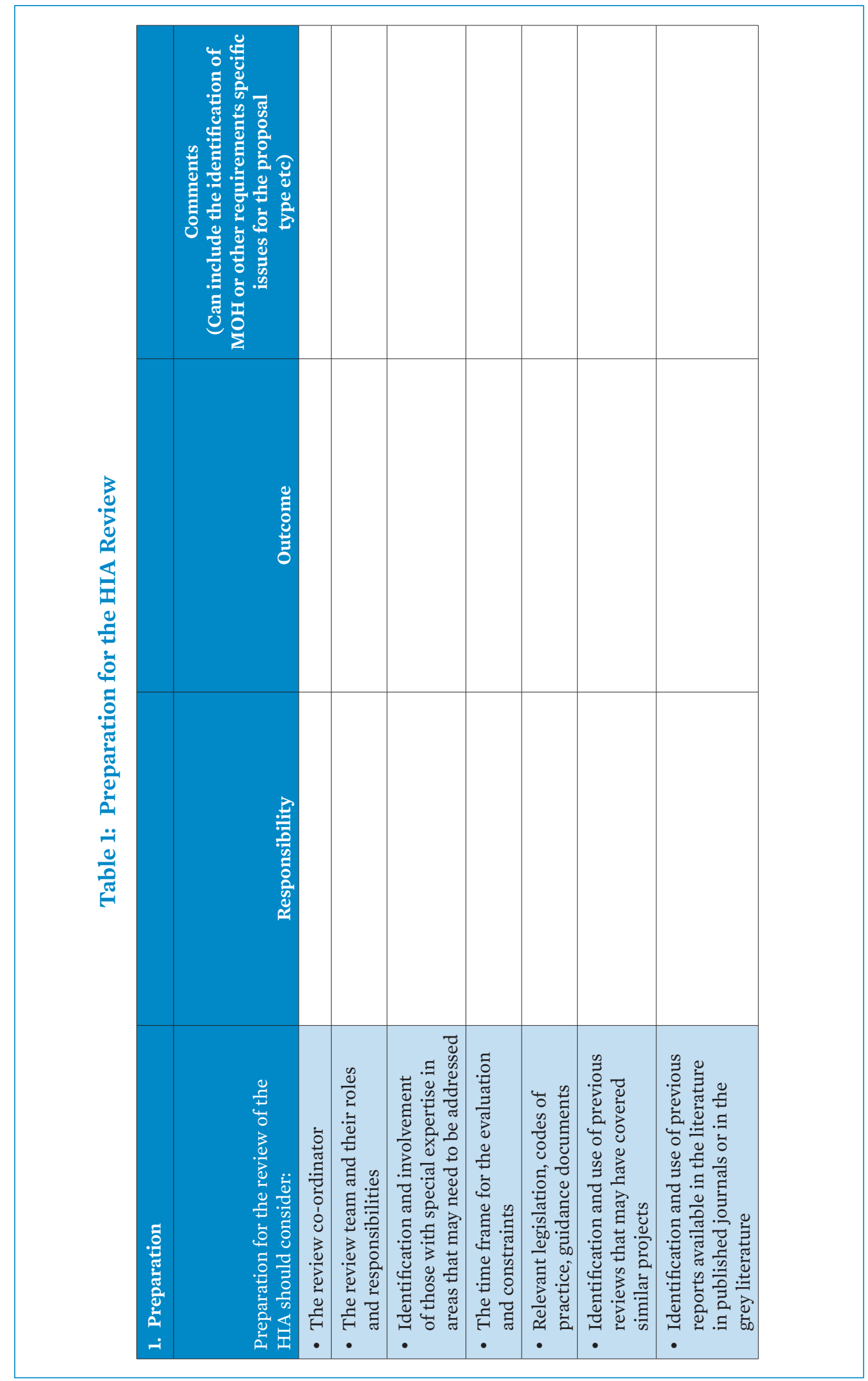




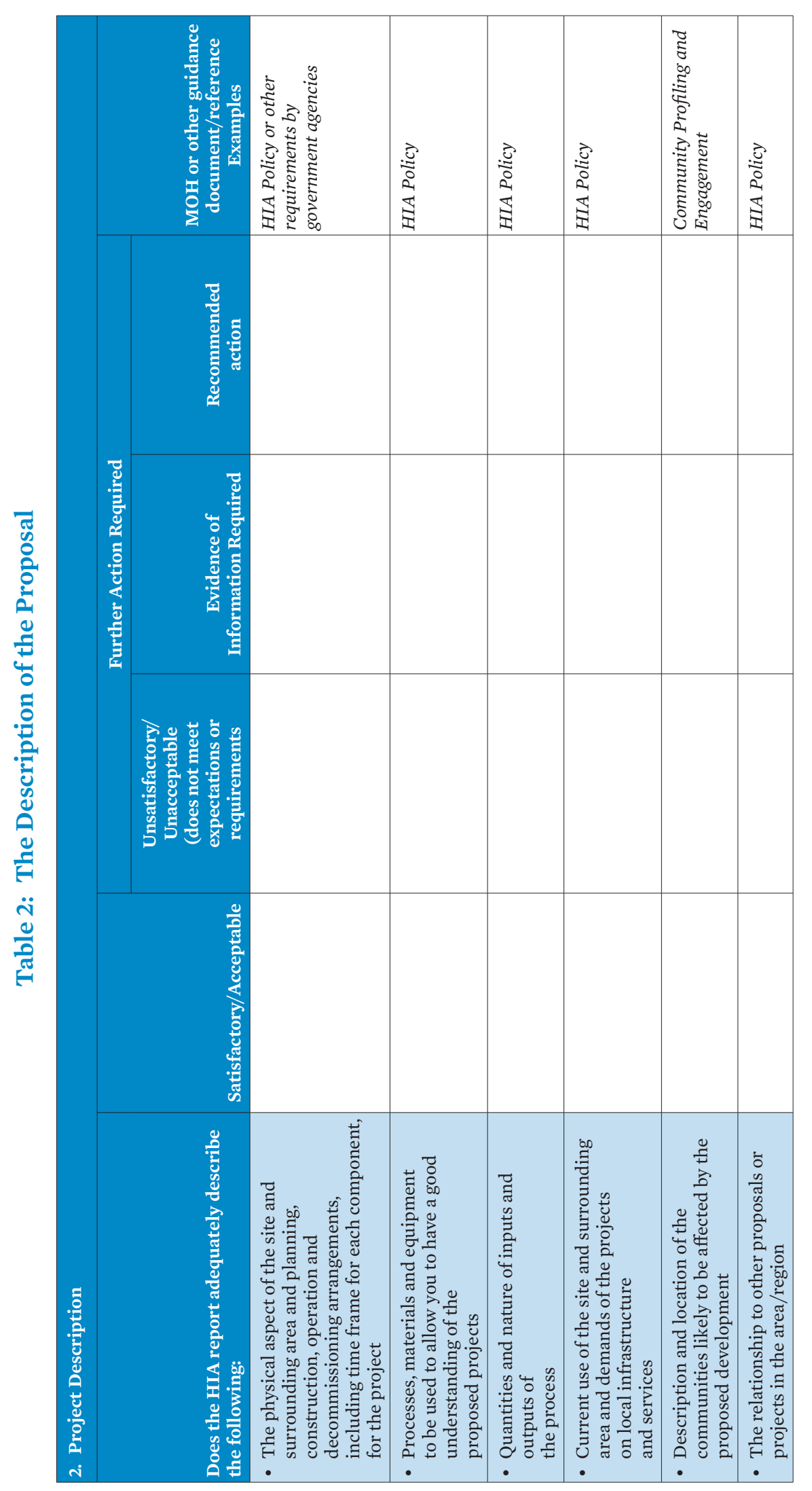




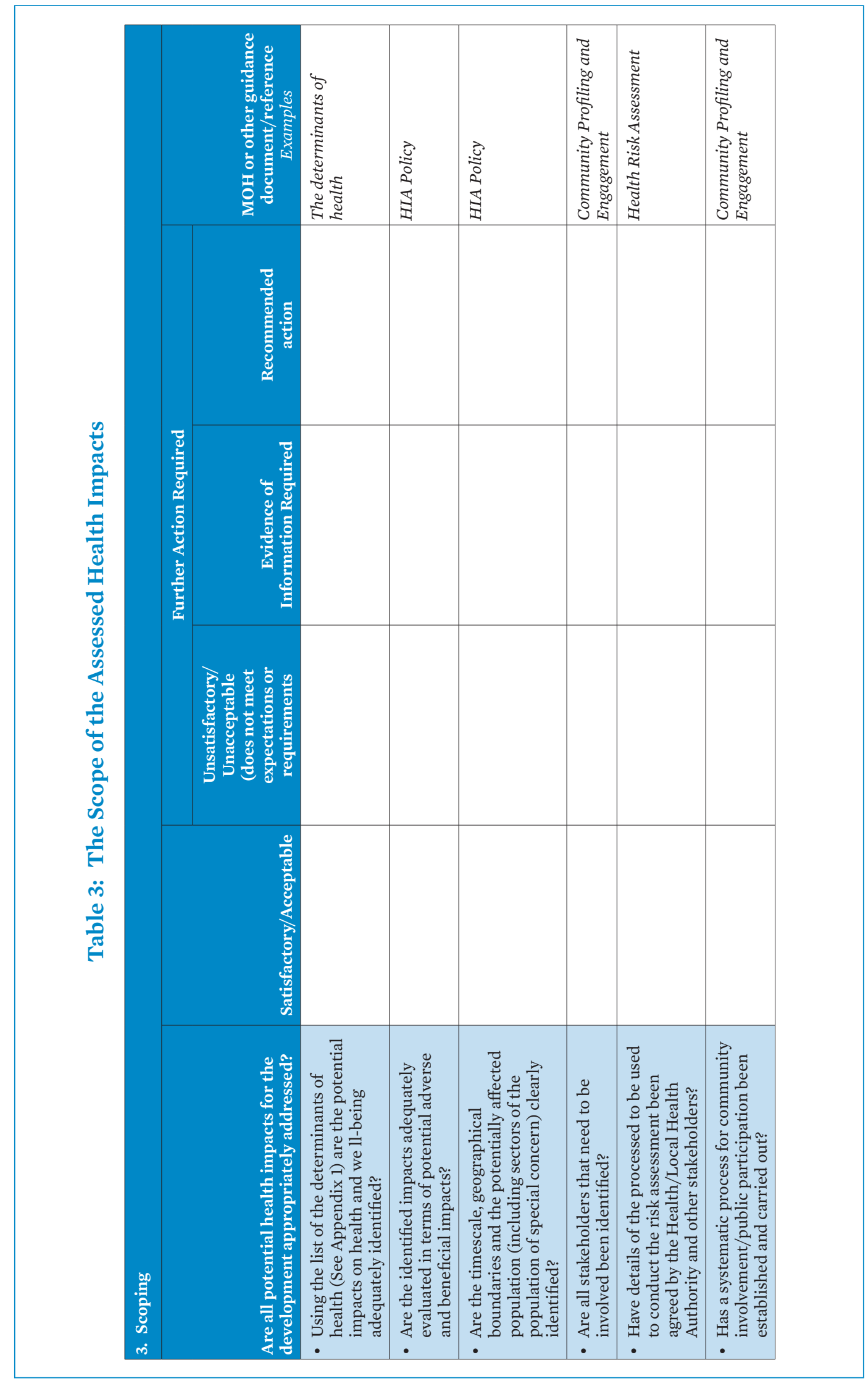




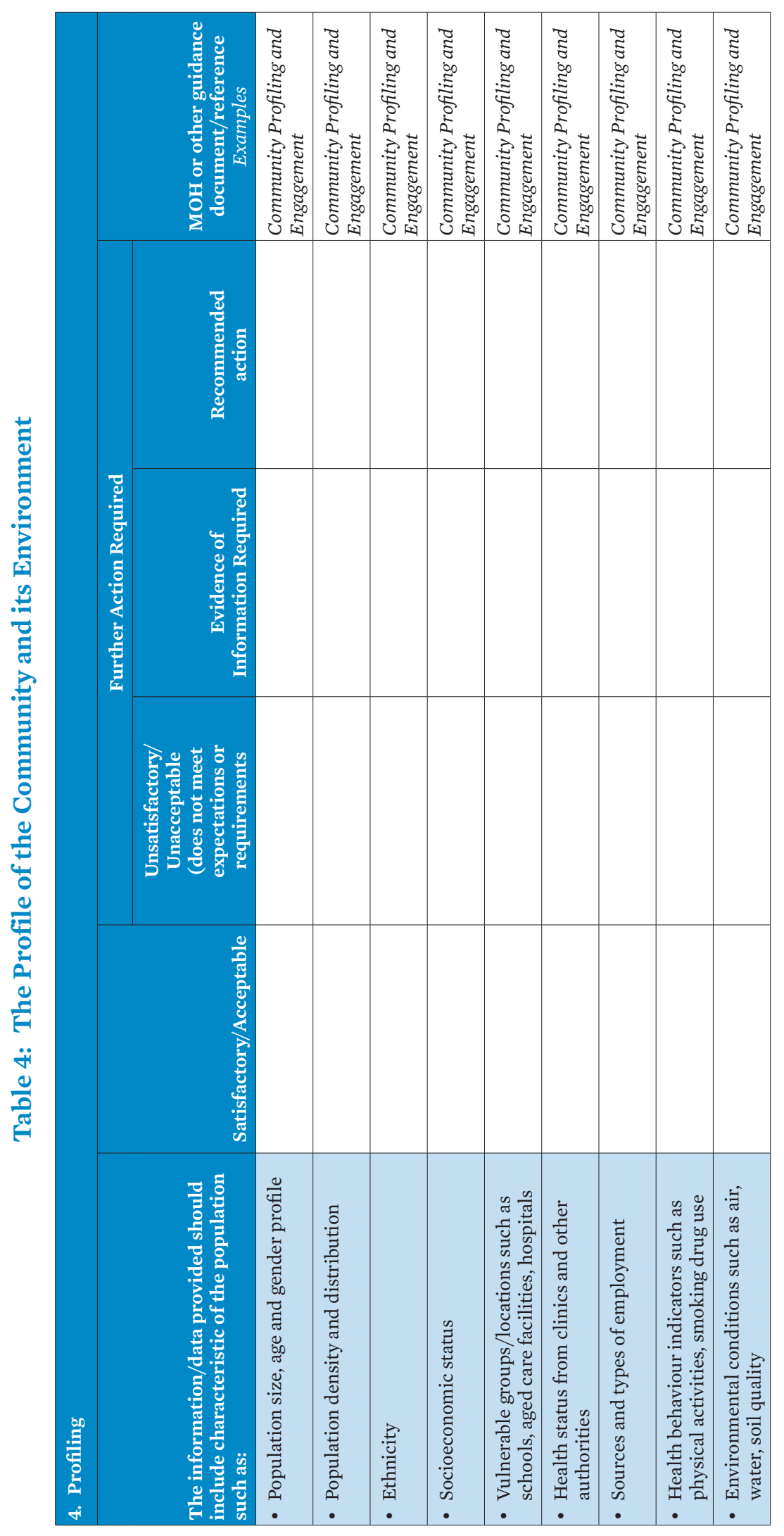




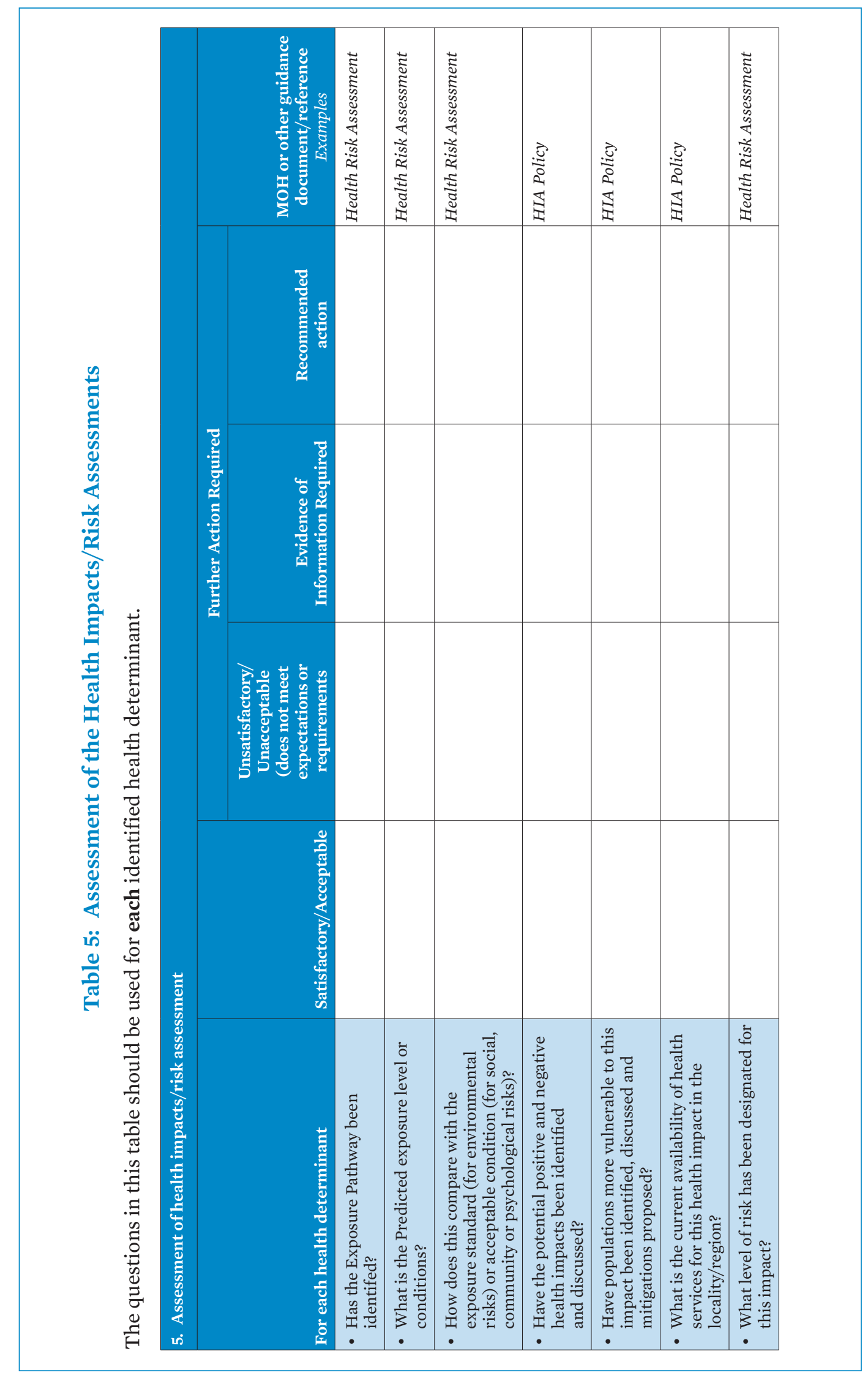




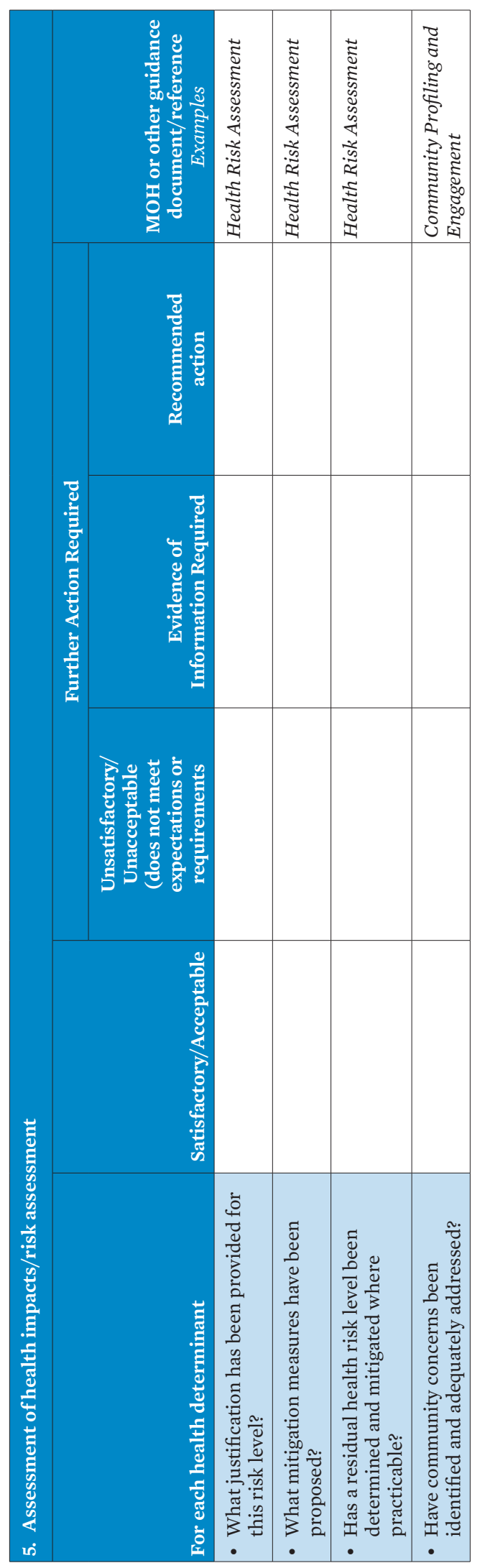




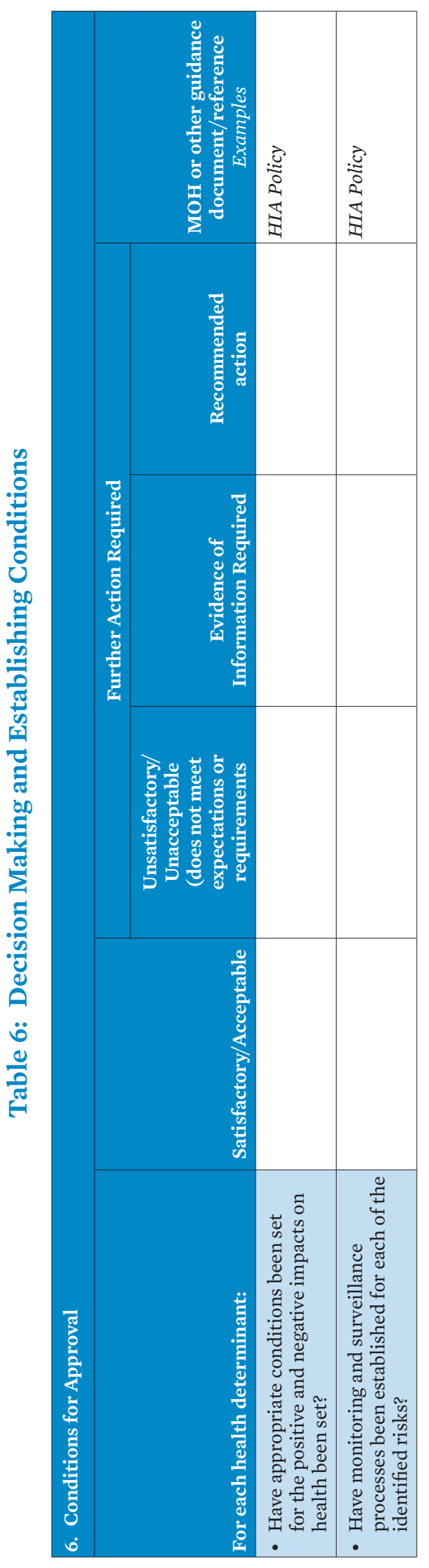




\section{Appendices}




\section{Appendix 1: The Determinants of Health}

\begin{tabular}{|c|c|c|}
\hline \multicolumn{3}{|c|}{ Modifiable Determinants of Health } \\
\hline Main Determinant & Determinant Subcategory & Example \\
\hline \multirow[t]{3}{*}{ Individual and family } & Physiological & $\begin{array}{l}\text { Vaccination status } \\
\text { Nutrition }\end{array}$ \\
\hline & Behavioural & $\begin{array}{l}\text { Lifestyle and daily routine } \\
\text { Physical activity } \\
\text { Use of tobacco, alcohol and other drugs } \\
\text { Risk taking behaviour } \\
\text { Acceptability of health services }\end{array}$ \\
\hline & $\begin{array}{l}\text { Socio-economic } \\
\text { circumstances }\end{array}$ & $\begin{array}{l}\text { Income and wealth } \\
\text { Education and learning } \\
\text { Employment and economy }\end{array}$ \\
\hline \multirow[t]{3}{*}{ Environmental } & Physical & $\begin{array}{l}\text { Housing and shelter } \\
\text { Transport and connectivity } \\
\text { Exposure to chemicals } \\
\text { Agriculture and food supply } \\
\text { Land and spatial - soil, water, air }\end{array}$ \\
\hline & Social & $\begin{array}{l}\text { Community infrastructure } \\
\text { Crime and safety } \\
\text { Leisure and recreation } \\
\text { Arts and culture } \\
\text { Faith, spiritual and traditional } \\
\text { Social capital and community cohesiveness }\end{array}$ \\
\hline & Economic & $\begin{array}{l}\text { Employment and economy investment } \\
\text { Access to goods and services } \\
\text { Affordability of health services }\end{array}$ \\
\hline \multirow[t]{3}{*}{ Institutional } & Organisation of health care & $\begin{array}{l}\text { Availability of health services } \\
\text { Accessibility of health services } \\
\text { Adequacy of health services } \\
\text { Quality of health services }\end{array}$ \\
\hline & Other institutions & $\begin{array}{l}\text { Social care } \\
\text { Police services } \\
\text { Emergency services } \\
\text { Judiciary } \\
\text { NGOs } \\
\text { Local government }\end{array}$ \\
\hline & Policies & $\begin{array}{l}\text { Governance and public policy } \\
\text { - industrial, health, transport, housing, etc. } \\
\text { Private sector norms } \\
\text { Third sector norms }\end{array}$ \\
\hline
\end{tabular}




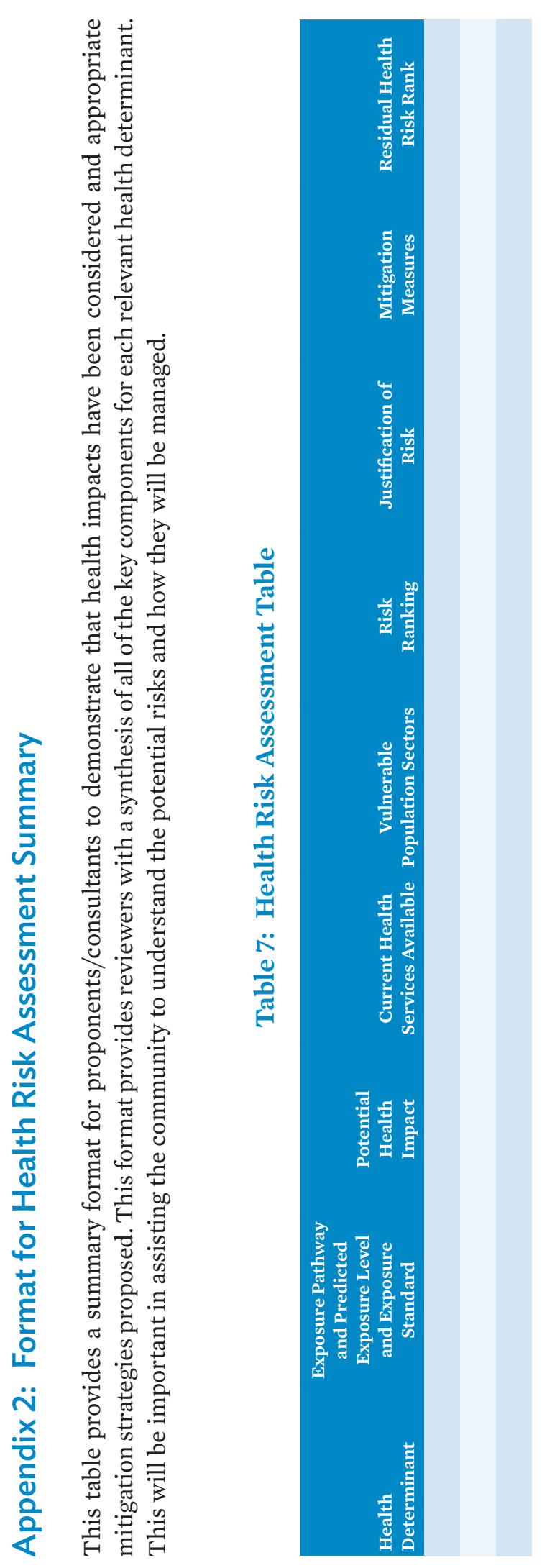




\section{Bibliography}

- EnHealth. 2001. Health Impact Assessment Guidelines. Commonwealth of Australia

- International Council on Mining and Metals. Undated. Good Practice Guidance on the Importance of Health Impact Assessments (online) http://www.icmm.com/ document/792

- World Health Organisation. Undated. Evaluating your HIA. (online) http://www.who .int/hia/evidence/eva/en/ 


\section{Health Impact Assessment A Good Practice Sourcebook}

This sourcebook provides up-to-date information regarding ADB environmental safeguards, poverty and social analysis, and compliance procedures in order to support the process of health impact assessment. It is a useful reference for ADB staff, borrowers, executing agencies, consultants, and others seeking a better understanding of how to implement health impact assessments. The publication outlines the procedures, methods, and tools that health impact assessments use to systematically judge the potential effects of a policy, plan, program, or project on the health of a population. It is useful to those who are producing a health impact assessment or public health management plan.

\section{About the Asian Development Bank}

ADB is committed to achieving a prosperous, inclusive, resilient, and sustainable Asia and the Pacific, while sustaining its efforts to eradicate extreme poverty. Established in 1966, it is owned by 67 members48 from the region. Its main instruments for helping its developing member countries are policy dialogue, loans, equity investments, guarantees, grants, and technical assistance. 